ROBSON BARBOSA

\title{
A GESTÃO E O USO EFICIENTE DA ENERGIA ELÉTRICA NOS SISTEMAS DE ILUMINAÇÃO PÚBLICA
}

\begin{abstract}
Dissertação apresentada ao Programa Interunidades de Pós-Graduação em Energia (Instituto de Eletrotécnica e Energia, Escola Politécnica, Faculdade de Economia e Administração e Instituto de Física) da Universidade de São Paulo.
\end{abstract}

SÃO PAULO

2000 
ROBSON BARBOSA

\title{
A GESTÃO E O USO EFICIENTE DA ENERGIA ELÉTRICA NOS SISTEMAS DE ILUMINAÇÃO PÚBLICA
}

\author{
Dissertação apresentada ao Programa \\ Interunidades de Pós-Graduação em Energia \\ (Instituto de Eletrotécnica e Energia, Escola \\ Politécnica, Faculdade de Economia e \\ Administração e Instituto de Física) da \\ Universidade de São Paulo.
}

Área de concentração: Energia

Orientador: Prof. Dr. Ildo Luis Sauer

SÄO PAULO

2000 
Aos meus pais Manuel e Maria Barbosa, que possibilitaram-me chegar até aqui À minha esposa Adilene, pela compreensão e apoio constantes Às minhas filhas Naara e Ohana, luzes do futuro Aos meus irmãos Rui, Ricardo, Vânia, Rômulo, Roberto, Valéria, Vitória, Renan, Raniere, Waleska e Viviane, que sempre acreditaram em mim 


\section{AGRADECIMENTOS}

Ao meu orientador, Professor Ildo Sauer, pela paciência e orientação segura. Um exemplo de coerência e dignidade no ensino da ciência.

A Universidade de São Paulo, particularmente ao Instituto de Eletrotécnica e Energia, pela oportunidade de possibilitar-me mais um passo na minha formação acadêmica e intelectual.

Aos membros da banca examinadora.

Aos funcionários do IEE, especialmente às secretárias Nazaré e Flávia.

Aos professores do PIPGE, especialmente Ildo, Martins, Célio e Fagá.

Aos pilares do "Caldeirão Cultural", Orlando, Marcão, Fernando Figueiredo, Cássio e Cláudia.

Às minhas colegas Cristina, Mara e Mariana, pela amizade e discussōes acadêmicas.

Aos membros efetivos das cadeiras "extracurriculares" no clube dos funcionários e dos professores, sob o comando do Prof. Ildo: Edson Gomes (Macú), Martins, Zilles, Célio, Cristina, Orlando, Fagá e Eugênia.

Aos colegas do PROCEL, especialmente lone, Cláudia, Luiz Felipe, Adriano, Raad e Gabriela.

Ao amigo João Marcos, pela ajuda na elaboração das figuras e tabelas desta dissertação, o que motivou o convite para orientá-lo no seu trabalho de conclusão do curso de engenharia elétrica pela UFRJ.

Ao meus irmãos Renan e Vânia e a minha esposa Adilene, pelas correções gramaticais e ortográficas.

Aos meus amigos Adilton, Adilson, Diê, Erlie Amorim, José Vasconcelos e Doralice, por me ajudarem a viver em SAMPA.

A todos os que contribuiram de forma direta e indireta para a realização deste trabalho. 
Figura 2.1 Processo de uso final da energia elétrica na iluminação pública

Figura 2.2 Principais funções desempenhadas pela iluminação pública.

Figura 2.3 Tipologia da curva de carga da iluminação pública. .23

Figura 2.4 Consumo total de energia elétrica por classes.

Figura 2.5 Evolução da participação da IP no consumo total de energia elétrica. 24

Figura 2.6 Crescimento do consumo total de energia elétrica e da IP. 25

Figura 2.7 Ponto de entrega na iluminação pública. 34

Figura 2.8 Prestadores dos serviços de iluminação pública por região. 40

Figura 2.9 Propriedade das instalações de iluminação pública. 41

Figura 3.1 Fluxograma das tarifas baseadas nos custos marginais. 57

Figura 3.2 Taxas de crescimento das tarifas médias de IP por regiāo. .63

Figura 3.3 Princípios da rivalidade e da exclusão aplicados aos bens públicos e privados.

Figura 3.4 Cobrança da TIP nas regiöes brasileiras. 67

Figura 3.5 Forma de cobrança da TIP pelos municipios. 67

Figura 4.1 Fundamentos de mercado para eficiência energética. .88

Figura 5.1 Atratividade de projetos de investimentos. 104

Figura 5.2 Os atores da iluminação pública e suas motivações. 106

Figura 5.3 Participação das classes de consumo no mercado da SAELPA. 109 


\section{LISTA DE TABELAS}

TABELA 2.1 Consumo de energia elétrica no Brasil 1994/1998 (MWh).

TABELA 3.1 Consumo e faturamento mensais da IP por subgrupo tarifário. .59

TABELA 3.2 Tarifa média por classe, regional e Brasil ( $\$$ /MWh). 62

TABELA 3.3 Tarifa média de IP, regional e Brasil (R\$/MWh). 62

TABELA 4.1 Número de lâmpadas de IP instaladas no Brasil por região. 82

TABELA 4.2 Tipos de lâmpadas de IP instaladas no Brasil. .83

TABELA 4.3 Potência instalada na IP por região. .84

TABELA 4.4 Potência instalada por tipo de lâmpada. .84

TABELA 4.5 Potencial de conservação de energia elétrica na IP por região. .85

TABELA 5.1 Consumo de energia elétrica por classes na área da SAELPA. 109

TABELA 5.2 Premissas da análise econômica. 115

TABELA 5.3 Resultados da análise econômica. 
LISTA DE ABREVIATURAS E SIGLAS

\section{ABREVIATURAS}

\begin{tabular}{|c|c|}
\hline ABNT & Associaçäo Brasileira de Norma Técnicas \\
\hline ANEEL & Agência Nacional de Energia Elétrica \\
\hline BNDES & Banco Nacional de Desenvolvimento Econômico e Social \\
\hline $\operatorname{CCON}$ & Comitê Coordenador de Operações Norte-Nordeste \\
\hline CIE & Comission Internationale de L 'eclairage \\
\hline CME & Centro da Memória da Eletricidade no Brasil \\
\hline CMMAD & Comissão Mundial sobre o Meio Ambiente e Desenvolvimento \\
\hline CODI & Comitê de Distribuição \\
\hline CTN & Código Tributário Nacional \\
\hline DNAEE & Departamento Nacional de Águas e Energia Elétrica \\
\hline ELETROBRÁS & Centrais Elétrica Brasileiras S.A. \\
\hline ESCO & Energy Saving Company \\
\hline GLD & Gerenciamento pelo Lado da Demanda \\
\hline IBAM & Instituto Brasileiro de Administração Municipal \\
\hline IBGE & Instituto Brasileiro de Geografia e Estatística \\
\hline ICMS & Imposto sobre Circulação de Mercadorias e Serviços \\
\hline IP & lluminação Pública \\
\hline IPTU & Imposto Predial e Territorial Urbano \\
\hline IRC & Índice de Reprodução de Cores \\
\hline IUEE & Imposto Único sobre Energia Elétrica \\
\hline NBR & Normas Brasileiras \\
\hline OCDE & Organização para Cooperação e o Desenvolvimento Econômico \\
\hline ONS & Operador Nacional do Sistema \\
\hline PIB & Produto Interno Bruto \\
\hline PROCEL & Programa Nacional de Conservação de Energia Elétrica \\
\hline RGR & Reserva Global de Reversão \\
\hline SAELPA & Sociedade Anônima de Eletrificação da Paraiba \\
\hline TIF & Taxa de lluminação Pública \\
\hline
\end{tabular}


SIGLAS

\begin{tabular}{|c|c|}
\hline AT & Alta Tensão \\
\hline$\%$ & Porcentagem \\
\hline a.a. & ao ano \\
\hline BT & Baixa Tensão \\
\hline CCV & Custo do Ciclo de Vida \\
\hline CEE & Custo da Energia Economizada \\
\hline CCVA & Custo do Ciclo de Vida Anualizado \\
\hline CCVANE & Custo do Ciclo de Vida Anualizado Não Energético \\
\hline FC & Fator de Carga \\
\hline FRC & Fator de Recuperação de Capital \\
\hline GW & Giga-Watt \\
\hline GWh & Giga-Watt-hora \\
\hline $\mathbf{h}$ & hora \\
\hline $\mathbf{I}$ & Incandescente (lâmpada) \\
\hline kW & quilo-Watt \\
\hline $\operatorname{Lm}$ & Lúmen \\
\hline $\mathbf{M}$ & Mista (lâmpada) \\
\hline MIm & Mega-lúmen \\
\hline MT & Média Tensão \\
\hline MW & Mega-Watt \\
\hline MWh & Mega-Watt-hora \\
\hline PMJP & Prefeitura Municipal de João Pessoa \\
\hline $\mathbf{R} \$$ & Reais (Moeda do Brasil) \\
\hline TIR & Taxa Interna de Retorno \\
\hline TRS & Tempo de Retorno Simples \\
\hline VM & Vapor de Mercúrio (lâmpada) \\
\hline VPL & Valor Presente Líquido \\
\hline VSAP & Vapor de Sódio Alta Pressão (lâmpada) \\
\hline
\end{tabular}




\section{RESUMO}

O serviço de iluminação pública no Brasil é prestado pelos municípios e concessionárias de energia elétrica. Do ponto de vista institucional, este serviço é regulamentado por leis, decretos e resoluções, e do ponto de vista técnico, por normas especificas, que foram analisadas neste trabalho. Especial ênfase foi dada à análise dos conflitos de interesse entre os principais prestadores deste serviço e as propostas de mediação, com base na revisão do regulamento específico sobre o fornecimento de energia elétrica para iluminação pública, proposta pela Agência Nacional de Energia Elétrica - ANEEL.

Apresentamos ainda uma análise sobre a regulamentação geral das tarifas de energia elétrica e, em particular, sobre as tarifas de iluminação pública. No primeiro caso, fizemos uma revisão conceitual da teoria dos custos marginais, para determinação da estrutura tarifária, e apresentamos um exemplo de aplicação da metodologia adaptada no Brasil para o cálculo das tarifas de iluminação pública. No segundo, discutimos os três tipos de tarifas adotados na iluminação pública e as controvérsias na aplicação das mesmas por parte das concessionárias. A cobrança dos serviços aos usuários por meio da Taxa de lluminação Pública, foi analisada com base na teoria econômica e nos princípios tributários aplicados a essa espécie de tributo.

Sob a ótica de cada ator, identificamos as oportunidades e barreiras para eficiência energética, em particular na iluminação pública, setor (ou segmento) que no Brasil apresenta um potencial técnico de conservação de energia elétrica estimado em 553 MW. Este potencial equivale a uma redução de $23 \%$ na potência total instalada nos sistemas de iluminação pública, com a substituição de aproximadamente 10,8 milhões de lâmpadas. Finalmente, realizamos um estudo de caso na cidade de João Pessoa, capita! do Estado da Paraiba. Os resultados deste estudo registraram uma redução de $43 \%$ no consumo de energia elétrica no sistema de iluminação pública, pela substituição dos equipamentos existentes por outros mais eficientes.

Com base nesses resultados, concluímos que a eficiência energética e a gestão adequada dos sistemas de iluminação pública podem contribuir para reduzir a demanda de energia elétrica, melhorar a qualidade dos serviços e minimizar os impactos sociais e ambientais produzidos pela construção e operaçăo de novas usinas de geração de energia elétrica. Para tal, devem-se adotar estratégias que conciliem os interesses entre os principais atores e eliminem as barreiras existentes. Acreditamos que essa meta seria conseguida pela maior participação dos agentes públicos e privados e principalmente pelo aperfeiçoamento da legislação de incentivo à eficiência energética. 


\section{ABSTRACT}

Public lighting in Brazil is a service provided by cities and by utilities. From the institutional point of view this service is regulated through laws, codes, and resolutions, and from the technical point of view, it is regulated through specific rules and guides, which were analyzed in this work. Special emphasis was given to both, the analysis of the conflict of interests among the main providers of this service, and to proposals of mediation, based on the review of the specific regulation about the electrical energy supply for public lighting, proposed by the National Agency for Electrical Energy (ANEEL).

We also present an analysis about general regulation of electrical energy tariffs, and, in particular, about public lighting tariffs. Regarding the general regulation, we performed a conceptual review about marginal costs theory, used for the determination of the tariff structure, and presented an example of methodology application, used in Brazil for the calculation of public lighting tariffs. Concerning the public lighting tariffs, we discussed the 3 types of tariffs and controversies about their use by the utilities. These services are charged to consumers through the public lighting fees, which were also analyzed based on economic theory and on the taxing principles.

From the perspective of each actor, we identified opportunities and barriers for the energy efficiency. In public lighting, a technical savings potential amounting to $558 \mathrm{MW}$ was estimated for Brazil, by improving efficiency of approximately 10.8 million lamps, out of a total of 13 million lamps currently installed. This potential is equivalent to a $23 \%$ reduction in total peak power demand required by currently installed public lighting system. Finally, we performed a case study for the city of João Pessoa, the capital of Paraiba State. The results of this study showed a reduction of $43 \%$ in the consumption of electrical energy in the public lighting system, through the substitution of the existing equipment by more efficient one.

Based on these results, we concluded that the energy efficiency and adequate management of the public lighting systems could contribute to reduce the demand of electrical energy, to improve quatity of services and to minimize the social and environmental impacts due to construction and operation of new electric power plants. To achieve this goal, new strategies to conciliate interests among the main actors and to eliminate existent barriers should be adopted. We believe that these strategies could be reached though stronger engagement of public and private agents and, mainly, by enacting adequate legislation and by stimulating energy efficiency. 
Lista de figuras

Lista de tabelas

Lista de abreviaturas e siglas

RESUMO

"ABSTRACT"

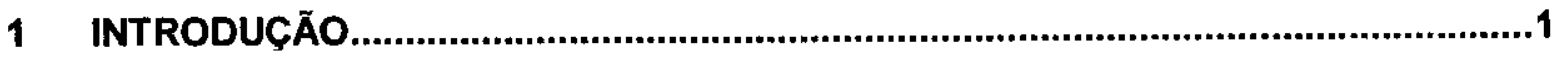

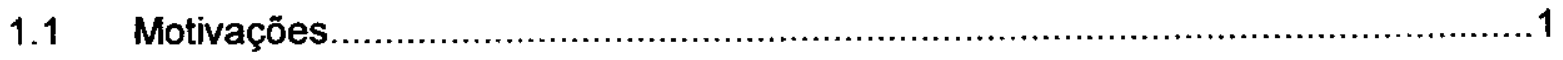

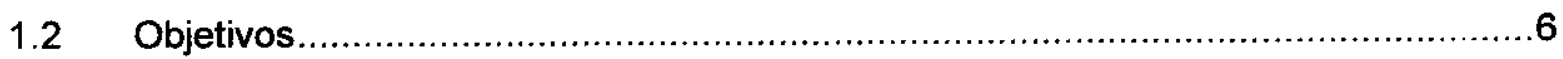

1.3 Justificativa e relevância da pesquisa......................................................

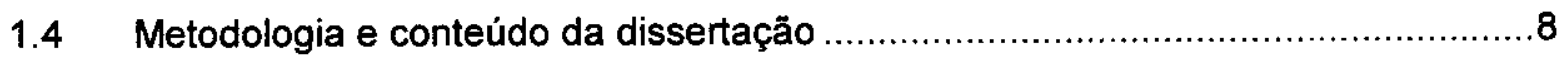

2 CARACTERIZAÇÃo dOS SERVIÇOS DE ILUMINAÇÃo PÚBLICA.....................11

$2.1 \quad$ Antecedentes históricos................................................................... 11

2.2 A iluminação pública como um uso final da energia elétrica ...........................14

2.3 As principais funções da iluminação pública ............................................15

2.4 As normas brasileiras sobre iluminação pública .........................................20

2.5 Características do consumo de energia elétrica na iluminação pública ...............22

2.5.1 Tipologia da curva de carga da iluminação pública ......................................22

2.5.2 Evolução do consumo de energia elétrica na iluminação pública.......................23

2.6 Conflitos entre concessionárias e municípios .............................................25

2.7 Regulamentação do fomecimento de energia elétrica para IP ..........................30

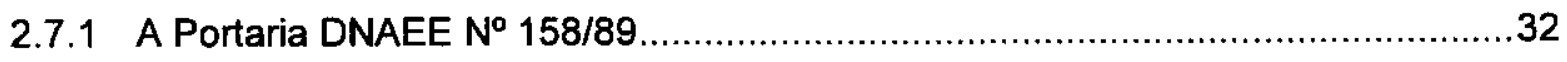

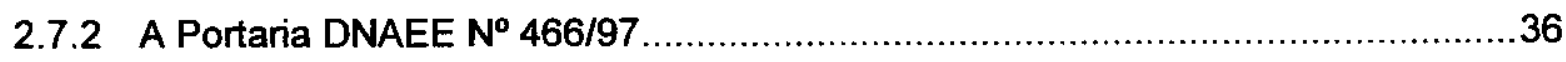



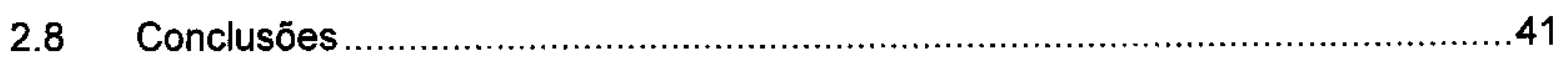


3.1 A política tarifária brasileira: uma breve retrospectiva histórica .45

3.2 Bases conceituais para definição das tarifas de energia elétrica .54

3.3 Os tipos de tarifas aplicados à iluminação pública .59

3.3.1 Polêmicas na aplicação das tarifas de iluminação pública 61

3.3.2 Os niveis de preços das tarifas de iluminação Pública 63

3.4 lluminação pública e o conceito econômico de bens sociais. .65

3.4.1 Fathas ou imperfeições de mercado associadas aos serviços de IP. 65

3.4.2 Gestão dos sistemas de IP: um mercado competitivo .67

3.5 A taxa de iluminação pública - TIP 68

3.5.1 Contestações sobre a legalidade da cobrança da TIP .70

3.5.2 Os exemplos da TIP em Maceió, Salvador e Rio de Janeiro .73

3.5.3 A cobrança dos serviços de IP no Equador e na Argentina. .76

3.5.4 Alternativas legais para o custeio dos serviços de IP .76

3.6 Conclusões .78

\section{OPORTUNIDADES E BARREIRAS PARA EFICIÊNCIA ENERGÉTICA NA}

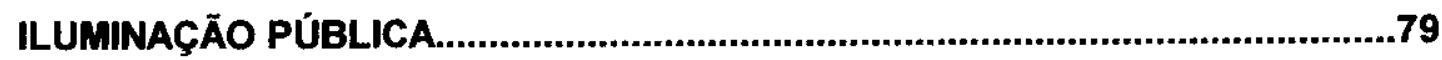

4.1 Bases para eficiência energética: breve revisão histórica e conceitual ..............79

4.2 O potencial de conservação de energia elétrica na iluminação pública................82

4.3 Oportunidades e barreiras para a eficiência energética ..................................86

4.4 Oportunidades para eficiência energética na iluminaçăo pública .......................91

4.5 Barreiras para eficiência energética na iluminação pública ..............................93

4.5.1 O programa nacional de conservação de energia elétrica - PROCEL .................96

4.5.2 Legislação de incentivo à eficiência energética no Brasil .................................99

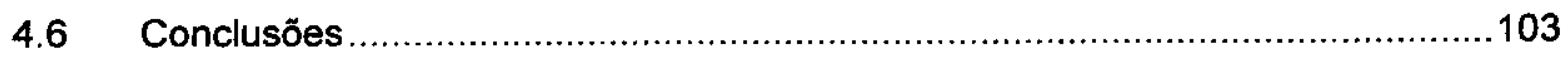


AVALIAÇÃO TÉCNICO-ECONÔMICA DE PROJETOS PARA EFICIÊNCIA ENERGÉTICA DE SISTEMAS DE ILUMINAÇÃO PÚBLICA. 104

5.1 Classificação de projetos de investimentos 104

5.2 Os principais atores da iluminação pública: papéis e motivaçōes .......................105

5.3 Estudo de caso: iluminação pública da cidade João Pessoa .............................108

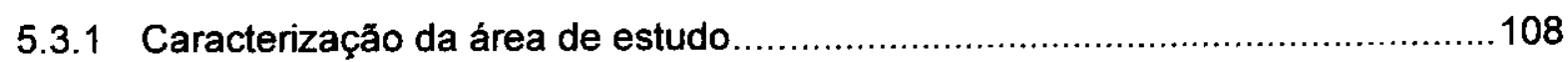

5.3.2 Figuras de mérito econômico e premissas adotadas......................................110

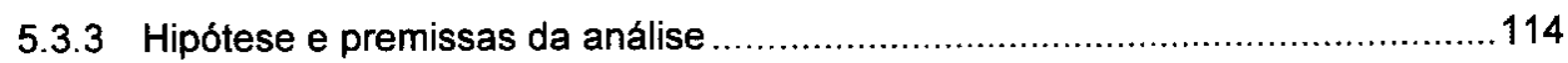

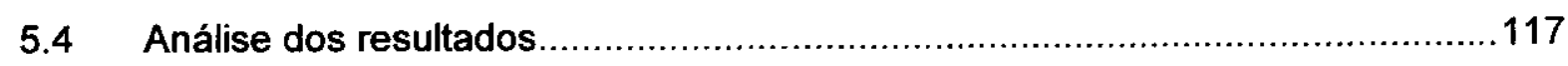

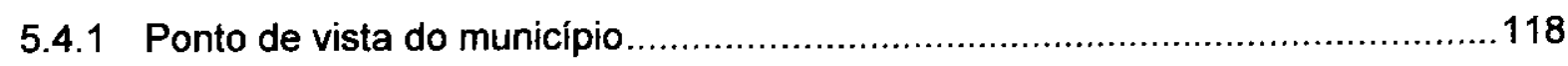

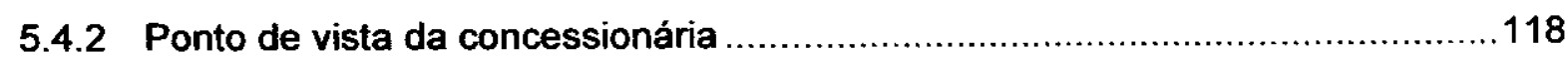

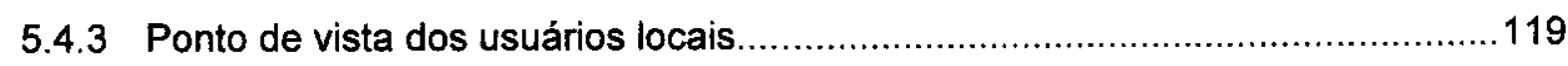

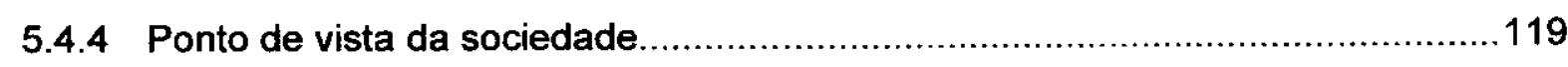

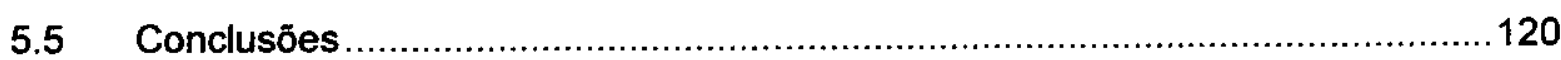

6. SINOPSE, CONCLUSÕES E RECOMENDAÇÕES.............................................121

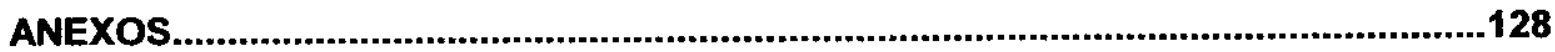

ANEXO I PORTARIA DNAEE No 158/89

ANEXO II MINUTA DE REVISÃO DA PORTARIA DNAEE № 158/89......................132

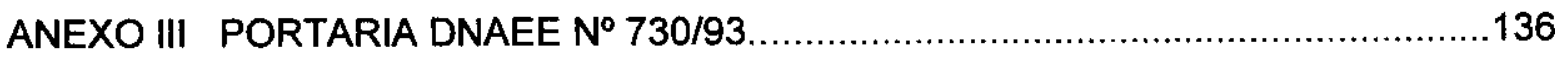

ANEXO IV ESTUDO DE CASO: MEMORIAL E PLANILHA DE CÁLCULOS................137

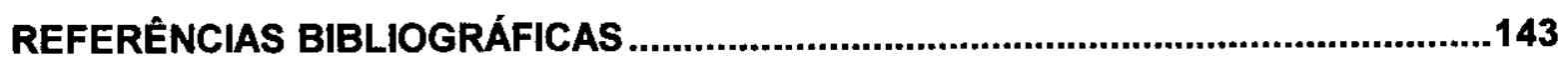

APÊNDICES.

APÉNDICE A PROJETOS DE SISTEMAS DE ILUMINAÇĀO PÚBLICA EFICIENTES..150 APÊNDICE B METODOLOGIA DE CALCULO DAS TARIFAS BASEADAS NOS CUSTOS MARGINAIS: O EXEMPLO DA ILUMINAÇĀO PÚBLICA ……….............160

APÊNDICE C GESTÃO DE SISTEMAS DE ILUMINAÇÃO PÚBLICA..........................173 APÉNDICE D PROPOSTAS DE EMENDA À CONSTITUIÇÃO FEDERAL E DE PROJETOS DE LEI COMPLEMENTAR SOBRE A TIP. 


\section{INTRODUÇÃO}

\subsection{Motivações}

\section{A importância da iluminação pública e o potencial para eficiência energética}

A iluminação pública é um uso final da energia elétrica de grande importância para os centros urbanos. Isto se deve principalmente às suas características de serviço essencial, por contribuir para a segurança pública nas cidades e para a melhoria da qualidade de vida da sociedade.

Do ponto de vista do consumo de energia elétrica, a iluminação pública é uma classe responsável por 3,5\% do total consumido no Brasil (ELETROBRÁS, 1999). Uma peculiaridade é que a demanda máxima associada ocorre ao longo de quase todo o horário de ponta, o que implica num elevado fator de responsabilidade na formação dos custos de capacidade do sistema elétrico (DNAEE, 1985).

Por meio da utilização de tecnologias eficientes nos sistemas de iluminação pública, é possivel reduzir a demanda no horário de ponta e combater o desperdício de energia elétrica, com a melhoria da qualidade do serviço. Essas ações também contribuem para postergar investimentos na expansão dos sistemas de geração, transmissão e distribuição de energia elétrica, e para minimizar os impactos sociais e ambientais inerentes a cada uma dessas etapas.

Estudos em todo o mundo comprovam que medidas para eficiência energética na iluminação pública proporciona, em média, entre $20 \%$ e $40 \%$ de economia no consumo de eletricidade desses sistemas. Segundo VIZHÑAY (1996), existem 90 MW de potência instalada na iluminação pública do Equador. Com a substituição 
de 370.000 lâmpadas ineficientes podem ser reduzidos $26 \mathrm{MW}$, o que representa uma economia anual de $29 \%$ no consumo de energia elétrica desse sistema. PEDRANTI (1997) estima que na Argentina a potência instalada nos sistemas de iluminação pública de 1.500 municípios, cerca de $534 \mathrm{MW}$, apresenta um potencial de conservação da ordem de $30 \%$, o que equivale a uma potência evitada de 160 MW.

No Brasil existem vários trabalhos que identificam o potencial de conservação de energia elétrica e comprovam a viabilidade técnico-econômica de medidas para melhoria da eficiência energética dos sistemas de iluminação pública.

BARBOSA ; SAUER (1996), por exemplo, em estudo realizado no sistema de iluminação pública da cidade de João Pessoa - PB, concluíram que a substituição

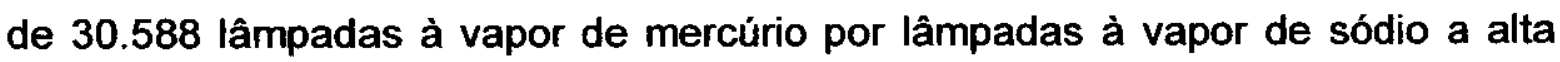
pressão, pode proporcionar a redução de $1 \mathrm{MW}$ na demanda. Isso representa uma economia anual de energia elétrica da ordem de $25 \%$ nesse sistema.

A potência instalada nos sistemas de iluminação de todo o Brasil é de cerca de $2.431 \mathrm{MW}$. O consumo de energia elétrica associado é de aproximadamente 10.380 GWh/ano. A ELETROBRÁS (1999) estima que exista um potencial técnico de redução da ordem de $23 \%$ na capacidade instalada nesses sistemas, o que representa um consumo evitado de $2.400 \mathrm{GWh} / a n o$. A realização desse potencial corresponde a uma economia de aproximadamente 1,5 bilhão de reais em novos investimentos na produção, transmissão e distribuiçăo de energia elétrica.

O financiamento de projetos para conservação de energia elétrica e o incentivo à eficiência energética no Brasil tiveram início a partir de 1985 com a criação do PROCEL - Programa Nacional de Conservação de Energia Elétrica. Esse programa, instituído pelo Governo Federal e executado pela ELETROBRÁS, utiliza recursos da Reserva Global de Reversão - RGR, um fundo criado para investimentos no setor elétrico, incluindo a conservação de energia elétrica. 


\section{Barreiras e oportunidades para eficiência energética na iluminacão pública}

Apesar do significativo potencial para melhoria da eficiência energética nos sistemas de iluminação pública, existem várias barreiras que impedem um maior avanço dessas açōes. Uma delas são os conflitos legais e institucionais entre os seus principais atores - municípios e concessionárias de energia elétrica.

Pela Constituição Federal do Brasil, a prestação dos serviços públicos de interesse local, nos quais se insere a iluminação pública, é de competência dos municípios. Entretanto, as atividades de implantação e manutenção são executadas diretamente tanto pelas concessionárias, quanto pelos municípios, ou seus prepostos.

Outra barreira diz respeito ao limitado acesso aos financiamentos para os projetos de eficiência energética, principalmente para os municipios de pequeno porte. Atualmente as opções oferecidas pelo mercado são restritas e as condiçōes financeiras são proibitivas.

Por outro lado, os recursos do PROCEL só estão disponiveis para as concessionárias de energia elétrica, embora a Lei 9.427 de 26 de dezembro de 1996 que instituiu a ANEEL autorize, no seu artigo 13, parágrafo $2^{\circ}$, incisos II e III, o financiamento direto aos Estados e municípios das regiōes Norte, Nordeste e Centro-Oeste. Face a essa restrição, os municipios geralmente têm que recorrer às próprias concessionárias que, nesse caso, atuam como intermediárias na obtenção dos recursos do PROCEL junto à ELETROBRAS.

No entanto, grande parte das concessionárias considera que investimentos para melhoria da eficiência energética dos equipamentos de uso final, a exemplo de lâmpadas e reatores de iluminação pública, reduzem o faturamento da empresa. 
FLAVIN ; LENSSEN (1994) concordam que não é razoável esperar que as concessionárias se interessem em vender menos o seu produto, considerando que elas faturam mais pela maior quantidade vendida.

Aliado a esses fatos, a inadimplência histórica de muitos municípios, reforça as dificuldades para implementação da eficiência energética na iluminação pública. Segundo a ANEEL (1999), até o mês de dezembro de 1998, 11 concessionárias distribuídas nas cinco regiões brasileiras, acumulavam um débito de $R \$$ 61.726.000,00 com a falta de pagamento das contas de energia elétrica de iluminação pública. O número de municípios em débito, 1.055 , corresponde a $37,7 \%$ do total de municipios existentes nas áreas de concessão dessas empresas.

Os municípios e suas entidades de representação, têm apontado a falta de recursos orçamentários como um dos motivos principais da inadimplência no pagamento do consumo de energia elétrica na iluminação pública. Historicamente, grande parte dos municípios brasileiros tem cobrado aos consumidores de energia elétrica e proprietários de terrenos urbanos, uma taxa para cobertura dos serviços de iluminação pública - a Taxa de Iluminação Pública, geralmente designada por TIP. No entanto, esse tributo tem sido julgado ilegal por tribunais de justiça de todo o país, agravando ainda mais a situação e contribuindo para acentuar os conflitos entre concessionárias e municípios.

Assim, a redução dos gastos com energia elétrica, proporcionada pelos projetos de melhoria da eficiência energética na iluminação pública, pode contribuir para a racionalização das despesas globais do município.

Por outro lado, do ponto de vista das concessionárias, além da escassez de recursos financeiros para expansão da oferta de energia elétrica, tem crescido, em âmbito mundial, as pressões para redução dos impactos sociais e ambientais causadas pelos empreendimentos energéticos. Isso tem estimulado as 
concessionárias de energia elétrica a adotarem o gerenciamento pelo lado da demanda e até mesmo a incentivarem a eficiência energética nos usos finais, como alternativas para otimizar a capacidade instalada ao menor custo.

\section{O cenário para eficiência energética na iluminação pública no Brasil}

O atual cenário do setor elétrico brasileiro, caracterizado pela privatizaçāo das concessionárias e as mudanças institucionais em curso, tem provocado incertezas quanto ao futuro da eficiência energética no país. Do mesmo modo, existe preocupação com relação aos custos dos serviços de operação e manutenção do sistema de iluminação pública prestados pelas concessionárias, cujos impactos econômicos e sociais para a sociedade precisam ser analisados.

Também é preciso averiguar quais as novas relaçōes entre municípios e concessionárias privatizadas, e que medidas podem ser adotadas para manter ou restabelecer o equilíbrio de forças entre eles. Outra questão relevante diz respeito às fontes de financiamento para projetos de melhoria da eficiência energética, tendo em vista que os recursos utilizados pelo PROCEL - a RGR, deverá ser extinta em 2002.

Portanto, a implementação de programas de conservação e uso eficiente de energia elétrica no setor da iluminação pública passa pela avaliação dessa problemática e pelas análises do papel e dos interesses dos principais atores envolvidos. Nesse contexto, espera-se que através da mitigação dos conflitos existentes e o equacionamento das fontes de custeio e financiamento para iluminação pública, a sociedade seja beneficiada com um serviço de boa qualidade e preços justos.

Para viabilizar o potencial de conservação de energia elétrica nos sistemas de iluminação pública do Brasil também é necessário eliminar as barreiras existentes, 
criar condições institucionais adequadas e organizar $o$ mercado com a participação efetiva dos atores, principalmente, municípios, concessionárias, indústria de equipamentos de iluminação e agentes financiadores.

Enfim, com a adoção desse conjunto de medidas, espera-se que a eficiência energética na iluminação pública possa reduzir os gastos com energia elétrica e melhorar a qualidade do serviço, favorecendo a segurança pública e contribuindo para o aumento do bem-estar nas cidades.

\subsection{Objetivos}

Este trabalho tem como objetivos gerais:

- Caracterizar os serviços de iluminação pública, e identificar os problemas e seus reflexos sobre a eficiência energética;

- Analisar os conceitos e a metodologia para a definiçāo das tarifas de iluminação pública baseada na teoria de custos marginais;

- Discutir as questões legais e institucionais da taxa de iluminação pública e os critérios de cobrança dos serviços aos contribuintes.

Os objetivos específicos são os seguintes:

- Identificar as principais oportunidades e barreiras para o uso racional e eficiente da energia elétrica no setor de iluminação pública;

- Analisar as possibilidades e perspectivas de melhoria da eficiência energética e econômica dos sistemas de iluminação pública;

- Avaliar, nas perspectivas dos municipios, concessionárias de energia elétrica, usuários e sociedade, os benefícios econômicos e financeiros da 
implementação de um projeto de melhoria da eficiência energética na iluminação pública, por meio de um estudo de caso na cidade João Pessoa PB.

\subsection{Justificativa e relevância da pesquisa}

A eficiência energética e o combate ao desperdício de energia elétrica é uma das prioridades do Governo Federal com o Programa Nacional de Conservação de Energia - PROCEL. No caso da iluminação pública, é preciso promover a eficiência energética sem comprometer a qualidade desse serviço público, essencial para a segurança do tráfego noturno de veículos e de pedestres nas cidades.

Com este trabalho pretendemos oferecer contribuições para gestão e o uso eficiente da energia elétrica na iluminação pública, e apontar mecanismos que ajudem a eliminar as principais barreiras para atingir esses objetivos. Pretendemos ainda oferecer elementos para viabilizar o significativo potencial de conservação de energia elétrica nesse setor $e$, consequentemente, incentivar o melhor uso dos recursos energéticos do país.

Finalmente, esperamos sensibilizar os principais atores da iluminação pública sobre a permanente necessidade de melhorar a qualidade desse serviço, de indiscutivel necessidade para o bem-estar dos cidadãos, e estimular o desenvolvimento de futuras pesquisas nessa área, considerando as limitações deste trabalho. 


\subsection{Metodologia e conteúdo da dissertação}

No capítulo 2 analisamos as características gerais dos serviços de iluminação pública no Brasil com base no histórico da regulamentação inscrita em Leis, Decretos, Portarias do DNAEE, Resoluções da ANEEL e Constituição Federal do Brasil. A partir dessa análise, procuramos identificar a origem e a natureza dos conflitos existentes entre municípios e concessionárias de energia elétrica na prestação desses serviços.

Verificamos também até que ponto esses conflitos tiveram influência para a elaboraçăo da Portaria DNAEE 158/89, regulamento específico que estabelece as condições, critérios e procedimentos a serem observados no fornecimento de energia elétrica para iluminação pública.

Com base numa proposição de GARDNER ; ROBINSON (1994), ilustramos o processo de uso final de energia elétrica na iluminaçāo pública e destacamos as suas principais funçōes no cenário urbano das cidades. Fizemos também uma análise dos principais parâmetros luminotécnicos estabelecidos nas normas brasileiras da ABNT sobre iluminação pública - a NBR 5101: iluminação pública procedimento e os comparamos com os critérios da norma européia da Commission Internationale de L'éclairage CIE 115/95.

Recuperamos, com os dados de consumo realizado em 1998, a tipologia da curva de carga da iluminação pública levantada pelo DNAEE (1985). A partir dos dados de mercado do consumo de energia elétrica no Brasil de 1994 a 1988, realizamos uma análise sobre a evolução do consumo de energia elétrica na iluminação e sua participação no consumo total. 
Com base numa pesquisa realizada pelo PROCEL em convênio com o IBAM, apresentamos um panorama sobre a situação atual da prestação dos serviços de iluminação no Brasil, em que destacamos os dados estatísticos mais relevantes.

Com base na minuta produzida pelo Grupo de Trabalho constituído pela Resolução da ANEEL $n^{\circ} 41$, de 04.04.1998, fizemos uma análise das principais mudanças propostas na revisão da Portaria DNAEE No $158 / 89$, e suas possíveis repercussões para os municípios, concessionárias e usuários do serviço.

No capitulo 3 apresentamos uma análise histórica da regulamentação geral sobre as tarifas de energia elétrica no Brasil, e em particular das tarifas de iluminação pública. Fizemos uma revisão conceitual da teoria dos custos marginais e mostramos, com um exemplo do cálculo das tarifas de iluminação pública, a aplicação da metodologia desenvolvida pelo DNAEE, em conjunto com a ELETROBRÁS, para a definição da estrutura tarifária. Discutimos ainda os três tipos de tarifas aplicadas ao fornecimento de energia elétrica para iluminação pública e as polêmicas de interpretação que as têm caracterizado.

Encerramos esse capítulo com a discussão dos aspectos legais sobre a cobrança da Taxa de lluminação Pública - TIP, tributo que se constitui na fonte específica de receita para o custeio dos serviços de iluminação pública pelos municipios, e com a apresentação de experiências brasileiras e internacionais sobre a cobrança dos serviços de iluminação pública aos usuários.

No capitulo 4 apresentamos uma revisão sobre os conceitos de eficiência energética e análise de energia elétrica orientada para os usos finais, com base em estudos e experiências internacionais. Analisamos as oportunidades e barreiras para implementação da eficiência energética na iluminação pública, sob a ótica de cada ator, enfatizando a viabilidade técnica e econômica de programas de conservação de energia em todo o mundo. 
Com base numa pesquisa realizada pela ELETROBRÁS/PROCEL, apresentamos um panorama geral sobre os tipos de tecnologia e a quantidade de lâmpadas instaladas nos sistemas de iluminação pública do Brasil, e o respectivo potencial técnico de conservação de energia elétrica. Descrevemos os principais objetivos e estratégias do PROCEL para implementar a eficiência energética na iluminação pública, e destacamos as metas previstas para os próximos três anos. No final desse capítulo destacamos os principais dispositivos legais de regulamentação e incentivo à eficiência energética no Brasil.

No capítulo 5 realizamos um estudo de caso na cidade de João Pessoa, capital do Estado da Paraiba, em que avaliamos sob os pontos de vista do município, concessionária de energia elétrica, usuários do serviço e sociedade, os benefícios técnicos e econômicos proporcionados pela melhoria da eficiência energética do sistema de iluminação pública daquela cidade.

Nas análises econômicas utilizamos indicadores tradicionais: Tempo de Retorno Simples, Taxa Interna de Retorno, Relação Benefício/Custo e Valor Presente Líquido, e figuras de mérito específicas para projetos de eficiência energética nos usos finais de energia elétrica: Custo do Ciclo de Vida e Custo da Energia Economizada (SAUER, 1994).

No capítulo 6 apresentamos uma sinopse dos assuntos analisados neste trabalho e as conclusões finais. Finalizando, propomos recomendações para eliminar as principais barreiras para a gestão e o uso eficiente da energia elétrica nos sistemas de iluminação pública do Brasil. 


\section{CARACTERIZAÇÃO DOS SERVIÇOS DE ILUMINAÇÃO PÚBLICA}

\subsection{Antecedentes históricos}

As primeiras empresas geradoras de energia elétrica no Brasil surgiram entre o final do século $X I X$ e início do século $X X$, com a finalidade de atender os serviços municipais de iluminação pública. $O$ primeiro serviço de iluminação pública do Brasil e da América do Sul, por meio de energia elétrica, foi inaugurado no final de 1883 na cidade de Campos, no Rio de Janeiro (Centro da Memória da Eletricidade - CME, 1988).

Para o CME (1988), no primeiro periodo republicano, os municipios exerciam o papel de poder concedente dos serviços de energia elétrica devido à pequena dimensão do setor elétrico. JOHNSON et al (1996) consideram que a maior parte das concessões referentes à energia elétrica era da esfera municipal, provavelmente porque até as primeiras décadas do século $\mathrm{XX}$ a eletricidade não era vista como um suporte da atividade econômica, mas apenas para fornecer iluminação pública ou doméstica às cidades.

Segundo FARIAS NETO (1994), "a partir dos anos 30, ocorre um intervencionismo consciente do Estado, consubstanciado, em particular, no transcurso do período (1937/45) referente ao Estado Novo, em um regime verdadeiramente estatizante, com o subjacente conteúdo ideológico expresso pelo nacionalismo econômico. ${ }^{1}$

No setor elétrico, o que marca essa tendência é a edição do Código de Águas em 1934, que decreta a União como poder concedente dos serviços de energia

\footnotetext{
1 Na realidade, o estatismo, fundamentado pela atuação do Estado como investidor e regulador da atividade econômica, consistia em um determinante meio mais rápido e eficiente de promover o desenvolvimento" (FARIAS NETO, 1994, p.21).
} 
elétrica em substituiçāo aos Estados e municipios, e obriga a adaptação de todos os contratos de concessão existentes ao novo código.

ALBINO DE OLIVEIRA (1973) confirma que até 1934, o fornecimento de eletricidade era considerado uma atividade privada, exercida mediante contratos de concessão celebrados diretamente com as municipalidades. Com o advento da Constituição de 1934 e a publicação do Código de Águas, essa atividade passou a ser definida como serviço público.

Entretanto, mesmo com a transferência de competência dos serviços de energia elétrica para a União, ainda permaneceu reservada aos municípios a responsabilidade legal para exploração e prestação dos serviços de iluminação pública, conforme se verifica pelo artigo $8^{\circ}$, parágrafo único do Decreto Lei $\mathrm{N}^{\circ}$ 3.763, de 25.04.41:

"Art. $8^{\circ}$ - $O$ estabelecimento de redes de distribuição e o comércio de energia elétrica dependem exclusivamente de concessão de autorização federal."

"Parágrafo único - Os formecimentos de energia elétrica para serviços de iluminação pública, ou para quaisquer serviços públicos de caráter local explorados pelas municipalidades, serão regulados por contratos de fornecimento entre estas e os concessionários ou contratantes, observando o disposto nos respectivos contratos de concessão ou de exploração, celebrados com o Governo Federal, para distribuição de energia elétrica na zona em que se encontrar o município interessado".

Esse decreto, portanto, definiu a Uniāo como poder concedente dos serviços de energia elétrica no país, e estabeleceu a obrigatoriedade de celebração de contratos para a prestaçāo dos serviços de iluminação pública entre os municípios e as concessionárias. Também é considerado o primeiro marco legal que tratou diretamente do fornecimento de energia elétrica para iluminação pública e que a caracterizou como um serviço público de competência dos municípios (CODI, 1984). 
Ainda segundo FARIAS NETO (1994), entre 1940 e 1945, registrou-se uma maior intervenção direta do Estado na economia. Esse fato pode ser confirmado pelo movimento de mudança do controle acionário das concessionárias de energia elétrica, de privado para estatal.

Nesse cenário, é publicado em 1943, o Decreto Lei $N^{0} 5.764$, que ratifica a competência dos municípios para prestação dos serviços de iluminação pública:

"Art. $1^{\circ}$ - Enquanto não forem assinados os contratos a que se referem os artigos 202 do Código de Águas e 18 do Decreto Lei 852, de 11.11.38, os direitos e as obrigações das empresas de energia elétrica, coletivas ou individuais, continuarão a ser regidos pelos contratos anteriores celebrados, com as derrogações expressas na presente lei". ${ }^{2}$

"Parágrafo $1^{\circ}$ - A União substituirá automaticamente nesses contratos, desde a publicação desta lei, os Estados, o Distrito Federal, o território do Acre e os Municipios, salvo quanto as obrigações e pagamentos decorrentes do fornecimento de energia elétrica para iluminação e outros serviços públicos de natureza local".

O regulamento específico sobre os critérios e procedimentos a serem adotados no fornecimento de energia elétrica destinado à iluminação pública, foi estabelecido pelo Departamento Nacional de Aguas e Energia Elétrica - DNAEE, com a edição da Portaria № 158 de 17 de outubro de 1989. O DNAEE era o órgão concedente, regulador e fiscalizador dos serviços de eletricidade no Brasil à época, e foi sucedido pela Agência Nacional de Energia Elétrica - ANEEL. ${ }^{3}$

\footnotetext{
2 Esses artigos tratam da obrigatoriedade da revisăo dos contratos até entāo existentes.

3 A ANEEL foi constituida em 06 de outubro de 1997, através do Decreto $N^{\circ} 2.335$ e passou a funcionar a partir do dia 02 de dezembro de 1997.
} 


\subsection{A iluminação pública como um uso final da energia elétrica}

A iluminação pública é um uso final da eletricidade de peculiar importância. Como um fenômeno físico, a energia elétrica é convertida em luz através de uma tecnologia de uso final - a lâmpada elétrica; a partir do sistema de iluminação, é produzido o serviço energético desejado - a iluminação pública. Em outras palavras, é a utilização de um processo de conversão de energia elétrica para satisfazer uma das necessidades da sociedade moderna - a produção de luz artificial para o desenvolvimento de atividades humanas durante o período noturno. A figura 2.1 ilustra o processo de uso final da energia elétrica na iluminação pública.

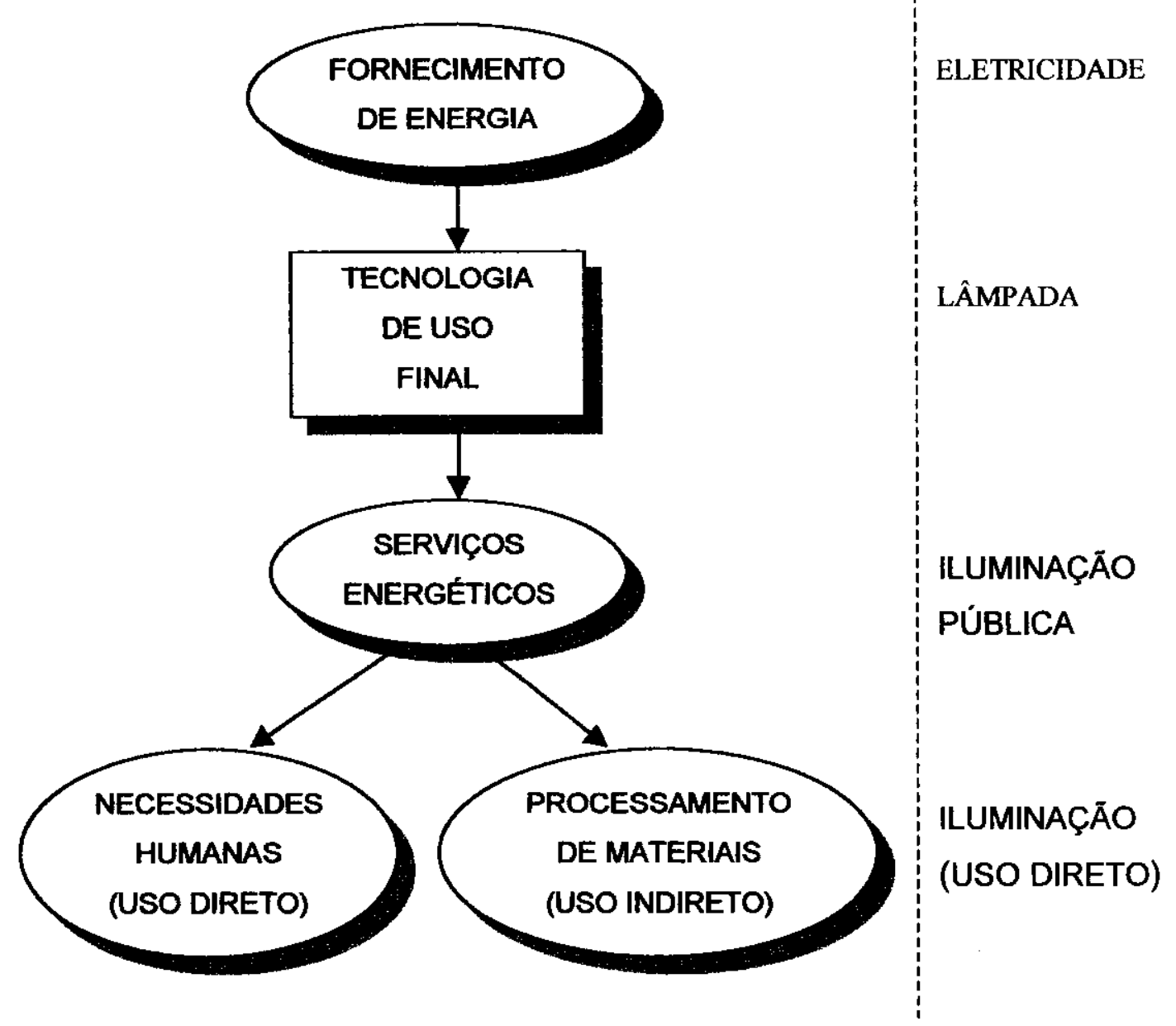

Figura 2.1 Processo de uso final da energia elétrica na iluminação pública. Fonte: GARDNER ; ROBINSON (1994). Adaptado. 
Em sua conceituação clássica, "iluminação pública é o serviço que tem por escopo prover de luz ou claridade artificial, no periodo noturno ou nos escurecimentos diurnos ocasionais, as ruas e logradouros públicos" (MEIRELLES, 1988, p.266). Do ponto de vista das concessionárias, iluminação pública é uma classe de consumo de energia elétrica, que se caracteriza pelo fornecimento de energia elétrica para iluminação de ruas, praças, avenidas, túneis, jardins, vias, estradas e outros logradouros de domínio público, de uso comum e livre acesso. ${ }^{4}$

É importante, porém, não confundir o serviço público de fornecimento de energia elétrica, prestado pelas concessionárias, com o de iluminação pública, de competência dos municípios, ainda que as redes de distribuição de energia elétrica tenham surgido inicialmente com a finalidade de suprir a iluminação das cidades, a partir da invenção da lâmpada de filamento incandescente por Thomas Edison em $1878 .^{5}$

\subsection{As principais funções da iluminação pública}

\section{lluminação pública e seguranca}

As principais funções desempenhadas pela iluminação pública traspassam as conceituações formal e física, haja vista que a iluminação de ruas, avenidas, estradas, praças e demais logradouros públicos, contribui efetivamente para a segurança do tráfego noturno de veículos e de pedestres.

No Brasil, ao contrário dos Estados Unidos e de países da Europa, não se dispõe de estatísticas ou pesquisas que correlacionem a contribuição da iluminação

\footnotetext{
4 A Portaria DNAEE $N^{\circ} 466$, de 12 de novembro de 1997, dispositivo que regulamenta as condiçōes gerais de prestação do serviço público de energia elétrica, determina que as concessionárias classifiquem as unidades consumidoras de acordo com a natureza da atividade nela exercida e com a finalidade a que se destina o uso da energia elétrica.

5 Segundo HÉMERY et al (1993), Edison construiu a primeira rede de iluminaçăo no ano de 1881, em Londres.
} 
pública para a redução de acidentes de trânsito e diminuição da criminalidade no período noturno.

Segundo CAYLESS ; MARSDEN (1983), pesquisas realizadas na Europa revelam que a iluminação pública adequada pode reduzir em até $30 \%$ indice de acidentes de trânsito no período noturno, e diminuir a criminalidade, o que comprova as suas características de serviço essencial aos habitantes dos centros urbanos. $^{6}$

Mesmo que existam polêmicas sobre metodologias ou resultados de pesquisas dessa natureza, parece não haver dúvidas de que as ocorrências criminais têm maior propensão a acontecer nos lugares ermos e/ou com pouca iluminação noturna, sobretudo a prática de arrombamentos, roubos de veículos e assaltos às pessoas. $^{7}$

\section{A iluminacão de vias para o tráfego de veículos e de pedestres}

Para atender as necessidades visuais dos usuários de um sistema de iluminação pública, devem ser satisfeitos requisitos fotométricos definidos pelas normas técnicas de acordo com o tipo e as características peculiares de cada logradouro. $\mathrm{Na}$ iluminação de vias para veículos motorizados, o sistema de iluminação deve proporcionar uma rápida, precisa e confortável visão ao motorista, possibilitando-o identificar obstáculos e objetos estranhos na pista e a tomar decisões, tais como freadas e ou manobras de direção defensiva.

\footnotetext{
6 De acordo com o Relatório Técnico da Commission Internationale de L'éclairage - CIE 92.1/1992-CiE92.1-1995, uma pesquisa realizada durante o ano de 1981, em Lyon, na França, demonstrou a existência de relação entre o nível de iluminância das ruas e o índice de criminalidade. Verificou-se que $\mathbf{4 0 \%}$ dos crimes aconteciam nas áreas de maior densidade de pessoas, cujos índices de iluminância se situavam abaixo de 5 lux; $32 \%$ entre 5 e 10 lux; $19 \%$ entre 10 e 15 lux, e $8 \%$ acima de 15 lux.

$7 \mathrm{Em}$ Lancashire, Inglaterra, a polícia comprovou um aumento médio de $55 \%$ na incidência de arrombamentos, assaltos a lojas e a pessoas, e furto de veículos, como consequiência da redução da iluminaçăo das estradas, CIE (1995).
} 
Nas áreas residenciais e vias exclusivas para pedestres, o sistema de iluminação deve produzir níveis adequados de iluminância para orientar o deslocamento das pessoas à noite e favorecer a segurança pessoal dos cidadãos. A iluminação de vias para o tráfego de veículos e de pedestres é considerado o papel funcional da iluminação pública (CIE, 1995).

\section{A iluminacão pública para valorizacão dos ambientes urbanos}

Além do seu papel funcional, a iluminação pública também é utilizada para ornamentação e embelezamento noturno das cidades. Este tipo de iluminação destaca e valoriza os monumentos de interesse cultural, artístico e ambiental, fontes luminosas, fachadas de prédios históricos e outros logradouros públicos de representatividade para o município.

Por esse enfoque, todo o sistema de iluminação pública, principalmente postes, suportes e luminárias, deve ser projetado para promover a sua integração arquitetônica e ambiental ao mobiliário urbano no período diurno, e para criar uma identidade noturna das cidades e de seus ambientes (CIE, 1995). Essa prática, adotada sobretudo no países europeus, ainda se constitui num atrativo turístico durante a noite. No Brasil tem sido desenvolvida em algumas cidades, a exemplo do Rio de Janeiro, Brasilia, Salvador e São Paulo.

Nas praças, praias e noutros logradouros específicos, a iluminação pública também funciona como um importante vetor de integração social, na medida em que possibilita, ao anoitecer, reuniōes de grupos para a prática de esportes, lazer e trabalho. Nesses casos, a iluminação pública proporciona melhores condições de visibilidade e mobilidade, e, sobretudo, mais tempo de convivência entre as pessoas. 
Para MIGUEZ (1997, p.64) "a iluminação pública tem um papel estrutural a desempenhar; ela é em efeito, o componente fundamental do olhar do cidadão: ela orienta, destaca, esconde ou transforma, integra ou isola".

\section{A influência da iluminação pública no conforto visual}

Um sistema de iluminação pública eficiente deve satisfazer os requisitos luminotécnicos definidos nas normas técnicas, utilizando as tecnologias apropriadas e ao menor custo. Atualmente, uma das lâmpadas mais utilizadas na iluminação pública é a de vapor de sódio a alta pressão - VSAP. Esse tipo de lâmpada tem elevada eficiência energética, mas apresenta baixo índice de reprodução de cores $(\mathrm{IRC})^{8}$.

A lâmpada VSAP produz uma luz amarelada e, em função dessa característica, sua instalação em logradouros públicos onde se deseja reproduzir as cores com fidelidade, a exemplo de áreas arborizadas e ajardinadas, tem sido polêmica. Isso pode ser explicado em razão do caráter psicofisiológico da visão e os distintos efeitos que a luz pode provocar em cada pessoa (COSTA, 1998).

Em que pese as reaçōes contrárias, a melhoria da eficiência energética dos sistemas de iluminação pública tem sido proporcionada, em grande parte, pela substituição das lâmpadas incandescentes, mistas, halógenas e vapor de mercúrio por lâmpadas VSAP.

KIRSCHBAUM (1997) considera que um dos principais objetivos da remodelação dos sistemas de iluminação pública é encontrar a articulação adequada entre demanda energética, impacto na paisagem urbana e conforto dos usuários.

8 O IRC é um número de 0 a 100 que classifica a capacidade relativa de uma fonte de luz artificial em reproduzir a cor do objeto iluminado. Para as lâmpadas VSAP o IRC é 20. (BARBOSA; ALMEIDA, 1998). 
O conceito de que os sistemas de iluminação devem ser concebidos dentro um enfoque multidimensional também é compartilhado por VEITCH ; NEWSHAM (1995). Para eles, "os sistemas de iluminação de qualidade devem atender a niveis de energia, de modo a conservar o meio ambiente e as fontes (com vistas às necessidades do ser humano) e, simultaneamente, cumprir sua tarefa imediata, atendendo às exigências sociais, de comportamento, estéticas, emocionais, de saúde e de segurança" (VEITCH ; NEWSHAM, 1995, p.58).

Assim sendo, satisfazer todos os usuários da iluminação pública parece não ser uma tarefa tão simples, pois as soluções passam por avaliaçōes subjetivas, peculiares a cada ser humano, e pela evolução tecnológica, com o objetivo de dotar as lâmpadas para iluminação pública de altos índices de eficiência energética e de reprodução de cores, com viabilidade econômica. A figura 2.2 resume as principais funções da iluminação pública.

Valorizaçāo e destaque de monumentos $\mathrm{e}$ fachadas
Auxilio à segurança pública

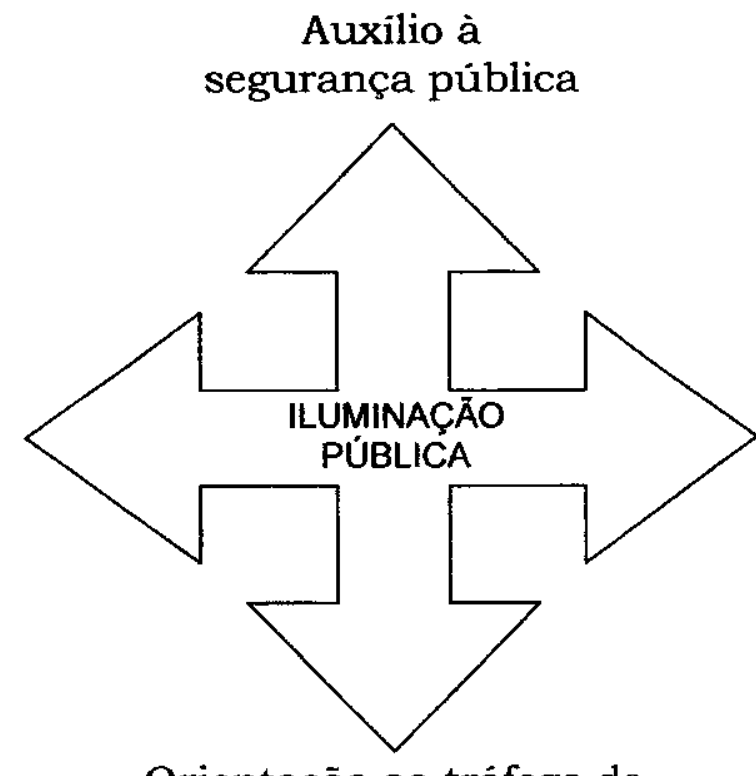

Orientação ao tráfego de veîculos e de pedestres
Encorajamento ao esporte e lazer noturnos

Figura 2.2 Principais funções desempenhadas pela iluminação pública. 


\subsection{As normas brasileiras sobre iluminação pública}

\section{Parâmetros luminotécnicos}

A norma brasileira que estabelece os requisitos básicos para iluminação pública de vias para o tráfego de veículos motorizados e de pedestres é a NBR 5101 lluminação Pública: Procedimento, que entrou em vigor a partir de 29 de outubro de 1992. ${ }^{9}$

$\mathrm{Na}$ iluminação de vias públicas, os dois principais requisitos de qualidade adotados pela NBR 5101 são nivel de iluminância média e fator de uniformidade de iluminância. A partir da classificaçăo da via segundo sua importância, tipo e volume de tráfego noturno, são recomendados valores médios mínimos que variam de 2 a 20 lux, para o nível de iluminância, e de 0,2 a 0,5 para o fator de uniformidade.

Estes valores são considerados os mínimos necessários para proporcionar condições de segurança aos pedestres e motoristas. A NBR 5101 apresenta ainda recomendações especiais para vias com tráfego complexo, a exemplo de cruzamentos de niveis, curvas e elevaçöes e pistas convergentes.

No APÊNDICE A, apresentam-se os principais conceitos e procedimentos básicos para elaboração de projetos luminotécnicos de sistemas de iluminação pública eficientes, com base nos parâmetros definidos pela NBR 5101.

9 Até o encerramento desta pesquisa, fevereuro de 2000, a NBR 5101 encontrava-se em revisão. 


\section{Controle do ofuscamento}

Ofuscamento é a sensação desagradável de desconforto visual, causado por uma luminância excessiva no campo visual (ofuscamento direto), ou pelo posicionamento inadequado de luminárias, quando as imagens refletidas aparecem na mesma direção ou numa direção próxima do objeto observado (ofuscamento por reflexão) (CIE, 1995).

A NBR 5101 não define qualitativamente o fenômeno do ofuscamento causado pelas fontes de luz artificiais, mas recomenda o controle do ângulo vertical de intensidade luminosa máxima das luminárias para evitá-lo.

Situaçōes de ofuscamento podem comprometer a performance visual do motorista e sua intensidade depende do tamanho da fonte de luz, de sua posição relativa ao observador e do brilho do entorno e do fundo da região onde está essa fonte. $O$ ofuscamento pode ser minimizado pelo posicionamento adequado das luminárias e/ou através da utilização de refratores. A sua limitação efetiva é um importante critério para obter-se uma iluminação pública adequada e para evitar riscos de acidentes (CIE, 1995).

\section{Os principais parâmetros luminotécnicos adotados na norma CIE 115/95}

A norma $\mathrm{CIE} 115 / 95$, entre outras normas internacionais, adota, como critério para iluminação de vias para tráfego motorizado, o conceito de luminância. Os principais requisitos de qualidade recomendados são uniformidade de luminância da superfície da via e controle do ofuscamento. Os valores de luminância média, a serem determinados para cada tipo de via, levam em consideração a distribuição fotométrica das luminárias de acordo com a lâmpada utilizada e as caracteristicas de reflexão do pavimento da via. 
No caso de áreas para pedestres, ainda segundo a CIE (1995), a iluminação pública deve facilitar o reconhecimento facial a partir de uma distância que torne possivel uma atitude de defesa numa situação de perigo. Normalmente essa distância varia entre 4 ( 1 lux no nível da face) e 10 metros ( 3 lux no nível da face).

$\mathrm{Na}$ iluminação de vias para pedestres, a norma CIE $115 / 95$ adota o critério de iluminância. Para esses logradouros são recomendados niveis de iluminâncias horizontal e vertical para identificar obstáculos, facilitar o deslocamento do pedestre com segurança e para possibilitar o reconhecimento de pessoas. Adota ainda o critério de controle do ofuscamento, embora essa situação não seja tão crítica no caso de pedestres.

\subsection{Características do consumo de energia elétrica na iluminação pública}

\subsubsection{Tipologia da curva de carga da iluminação pública}

No Brasil, os sistemas de iluminação pública funcionam, em média, a partir das 18:00 horas de um dia, até às 06:00 horas do dia seguinte. O periodo de demanda máxima do sistema elétrico, o "horário de ponta", compreende-se das 17:00 às 22:00 horas (DNAEE, 1985). Uma das principais características do consumo de energia elétrica na iluminação pública é que grande parte dele ocorre durante o horário de ponta. A figura 2.3 mostra a curva de carga típica da iluminação pública com a indicação do intervalo de ponta. 


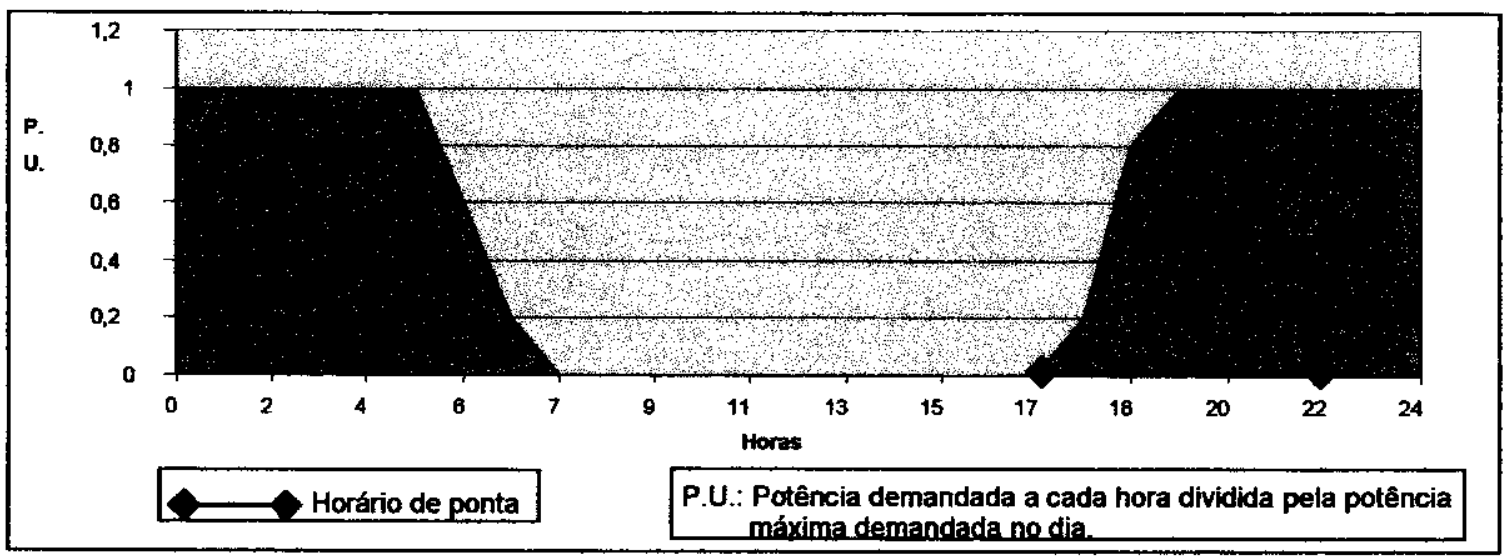

Figura 2.3 Tipologia da curva de carga da iluminação pública.

Fonte: DNAEE (1985). Adaptado.

\subsubsection{Evolução do consumo de energia elétrica na iluminação pública}

A tabela 2.1 apresenta a evolução do consumo total de energia elétrica no Brasil, por classe de consumidor, no período de 1994 a 1998.

TABELA 2.1 Consumo de energia elétrica no Brasil 1994/1998 (MWh).

\begin{tabular}{|c|c|c|c|c|c|}
\hline 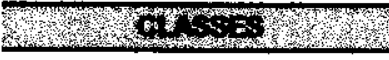 & 13 & 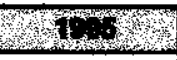 & 1 & $1+2$ & $1+1$ \\
\hline RESIDENCAAL & 55.955 .599 & 63.579 .490 & 68.581 .283 & 74.089 .154 & 79.340 .000 \\
\hline INDUSTRAAL & 107.373 .322 & 111.632 .220 & 117.127.595 & 121.717 .133 & 121.957 .498 \\
\hline COMERCIAL & 28.844 .838 & 32.277 .305 & 34.387 .694 & 38.197 .504 & 41.544 .094 \\
\hline RURAL & 8.360 .891 & 9.181 .280 & 9.926 .926 & 10.322 .473 & 11.378 .268 \\
\hline PODERES PÚBLCOS & 6.012 .980 & 6.606 .414 & 6.946 .600 & 7.581 .363 & 7.963 .511 \\
\hline RUMMACGÃO PÚBLCA & 8.306 .743 & 8.589 .072 & 9.008 .556 & 9.474 .070 & 9.869 .374 \\
\hline SERMÇOOS PÚBUCOS & 8.668 .310 & 8.998 .443 & 9.186 .275 & 9.324 .751 & 9.782 .237 \\
\hline PROPRIO & 2.008 .312 & 2.222 .393 & 2.165 .399 & 2.573 .514 & 2.539 .756 \\
\hline X & (2.1.2. & $2 \%, 11 \%$ & 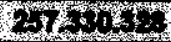 & 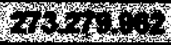 & 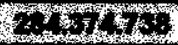 \\
\hline
\end{tabular}

Fonte: ELETROBRÁS (Plante/Mercado), 1999. 
O consumo de energia elétrica na iluminação pública em 1998, representou cerca de $3,5 \%$ do consumo total de energia elétrica do país, conforme mostrado na figura 2.4 .

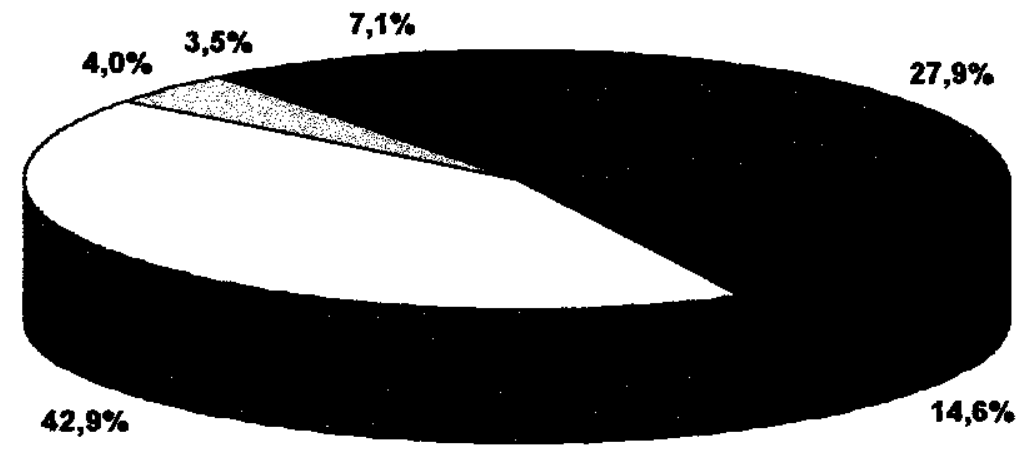

DResidencial comercial $\square$ Industrial D Rural DLP. D Outros *

• Outros - Poderes Públicos, Serviços Públicos e Próprio.

Figura 2.4 Consumo total de energia elétrica por classes.

Fonte: ELETROBRÁS (Plante/Mercado), 1999.

A figura 2.5 mostra que durante o período de 1994 a 1998, a participação da iluminação pública no consumo total de energia elétrica praticamente se manteve em torno dos $3,5 \%$.

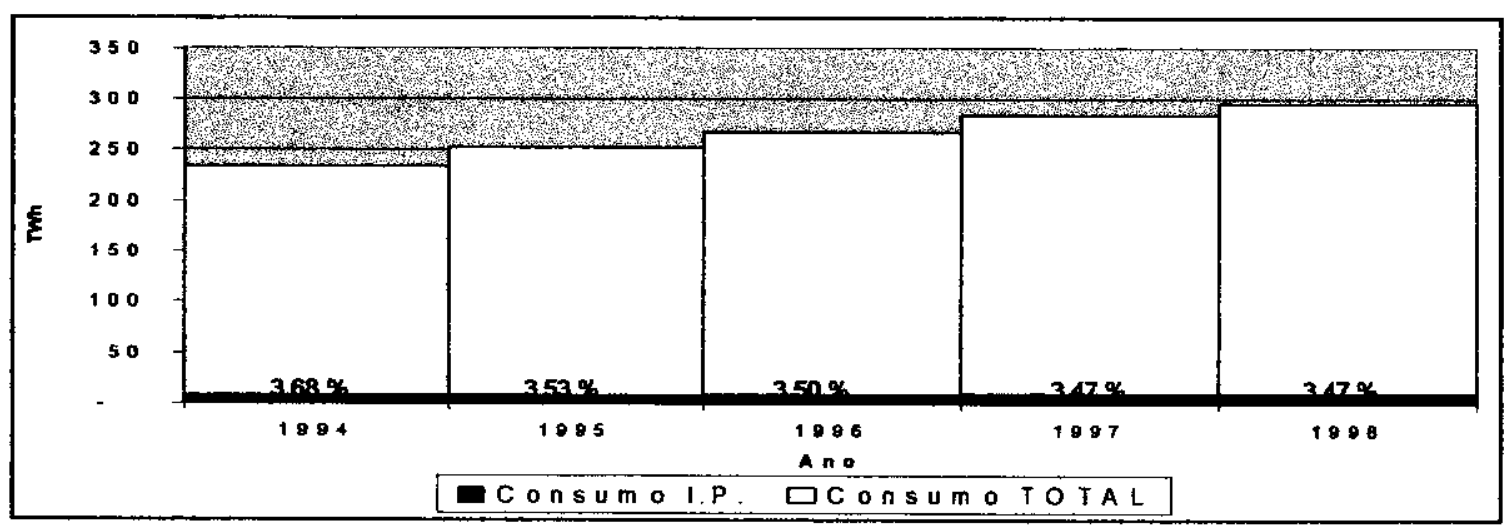

Figura 2.5 Evolução da participação da IP no consumo total de energia elétrica.

Fonte: ELETROBRÁS (Plante/Mercado), 1999. 
O comportamento das taxas de crescimento anual do consumo total de energia elétrica no Brasil e da iluminação pública é retratado na figura 2.6.

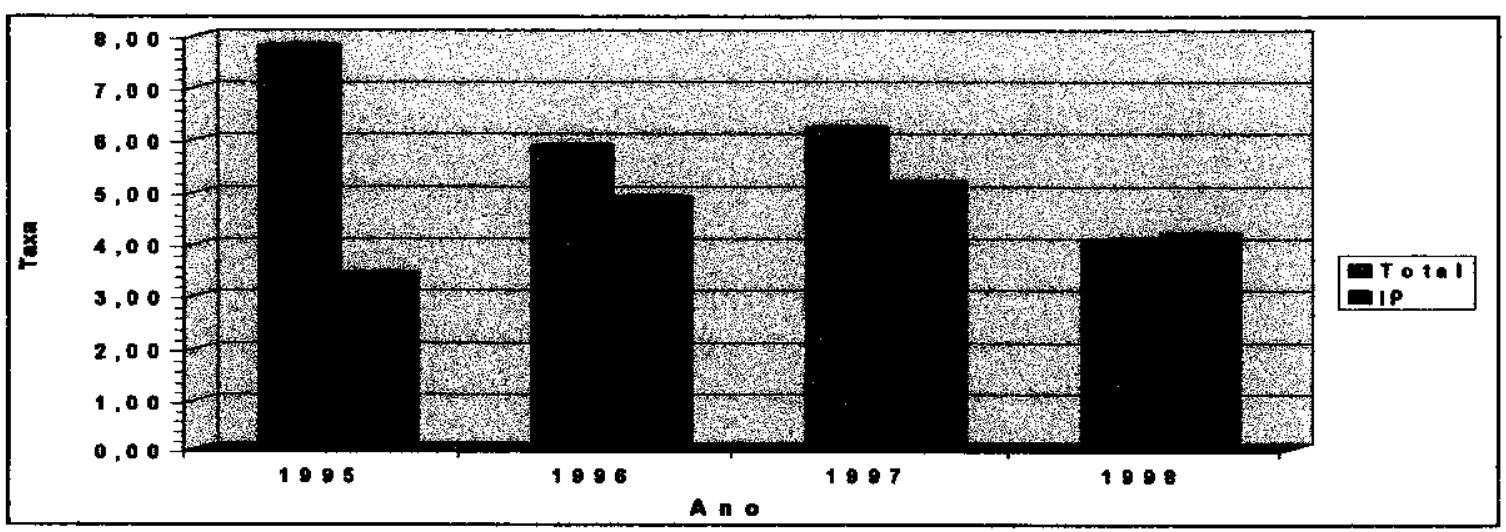

Figura 2.6 Crescimento do consumo total de energia elétrica e da IP. Fonte: ELETROBRÁS, 1999.

Observa-se que a taxa de crescimento do consumo total de energia elétrica caiu nos períodos entre 1995 / 1996 e entre 1997 / 1998. Nesses mesmos períodos a taxa de consumo de energia elétrica da iluminação pública manteve-se crescente, vindo a cair em 1998. Essa diminuição talvez se configure numa tendência, em razão das ações para melhoria da eficiência energética nos sistemas de iluminação pública, o que poderá ser confirmado com os dados de 1999, ainda não disponíveis ao término desta dissertação.

\subsection{Conflitos entre concessionárias e municípios}

Os conflitos entre concessionárias de energia elétrica e municipios na prestação dos serviços de iluminação pública são antigos e recorrentes, principalmente quanto aos limites de atuação de cada um, à propriedade das instalações e responsabilidade pelos investimentos, eà inadimplência no pagamento das contas de energia elétrica (DNAEE, 1986). 
As concessionárias - em menor número e organizadas em comitês técnicos e órgãos colegiados do setor elétrico - sempre tiveram maior poder de mobilização do que os municipios; estes, aos milhares, dispersos por todo o país e com realidades bem mais distintas.

\section{O ponto de vista das concessionárias}

Com o objetivo de avaliar a situação geral da prestaçăo dos serviços de iluminação pública junto às concessionárias, o CODI realizou um diagnóstico sobre os procedimentos comerciais adotados por 14 empresas, em que verificouse que 5 delas eram proprietárias do sistema de iluminação pública (CODI, 1983). ${ }^{10}$

Mesmo diante dessa constatação, o CODI (1983) entendia que sendo dos municípios a competência para exploração dos serviços de iluminação pública, o patrimônio das instalaçōes deveria ser de propriedade destes. Somente nos casos em que fosse de interesse de ambos, é que as concessionárias deveriam prestar os serviços, mediante contrato.

Por um lado, o fato de algumas concessionárias serem proprietárias das instalações de iluminação pública pode ser explicado em virtude do Decreto 41.019 , de 26 de fevereiro de 1957 , no seu artigo $5^{\circ}$, parágrafo $2^{\circ}$, admitir a hipótese do circuito de iluminação pública fazer parte do sistema de distribuição dessas empresas:

"Art. $5^{\circ}$ - O serviço de distribuição de energia elétrica consiste no fornecimento de energia a consumidores em média e baixa tensão".

\footnotetext{
10 O Comitê de Distribuiçāo - CODI, congregava as concessionárias das regiōes Sul, Sudeste e Centro-Oeste, e o Comitê Coordenador de Operaç̋̄es Norte/Nordeste - $\mathrm{CCON}$, as concessionárias das regiōès Norte e Nordeste.
} 
"Parágrafo $2^{\circ}$ - Os circuitos de iluminação e os alimentadores para tração elétrica até a subestação conversora, pertencentes a concessionárias de serviços de energia elétrica, serão considerados parte integrante de seus sistemas de distribuição".

Conforme apresentado no item 2.1, as empresas de energia elétrica surgiram no Brasil para fornecer eletricidade aos sistemas de iluminação pública, cujas instalaçöes integravam as respectivas redes de distribuição. A mudança do controle acionário de privado para estatal a partir da vigência do Código de Águas, e o processo de reversão dos bens e instalaçōes das empresas concessionárias de energia elétrica, parecem ter sido as principais causas dos conflitos entre municípios e concessionárias relacionados à propriedade do sistema de iluminação pública.

\section{A eqüalização tarifária e a remuneracão dos servicos de iluminação pública}

No período de 1974 e 1993 a tarifa de energia elétrica fixada para cada classe de consumidor tinha o mesmo valor em todo o país, o que se denominava de "eqüalização tarifária". Mesmo não sendo um problema decorrente desse critério, as concessionárias proprietárias de sistemas de iluminação pública que não dispunham de contrato especifico com os municipios regulamentando a prestação dos serviços de manutenção e o seu custeio, estavam sujeitas a prejuízos financeiros. Na prática, verificava-se dois casos extremos seguintes:

1) Município proprietário das instalaçōes de iluminação pública e responsável pelos serviços de manutenção e seus custos.

Neste caso a concessionária apenas fornecia energia elétrica para iluminação pública e a faturava mediante o nível tarifário estabelecido para esta classe, o que até aí se constitui numa situação normal; 
2) Concessionária proprietária do sistema de iluminação pública e responsável pelos serviços de manutenção e seus custos.

Neste caso a concessionária faturava apenas os valores correspondentes ao consumo de energia elétrica, mediante o mesmo nivel tarifário da concessionária referida no caso anterior. Em resumo, algumas concessionárias eram penalizadas, pois arcavam com os custos de manutenção do sistema de iluminação pública sem receber a devida contrapartida de remuneração.

\section{O ponto de vista dos municípios}

Em 1984, representantes de municípios e de várias entidades ligadas aos serviços de iluminação pública, promoveram um encontro de trabalho com o objetivo de traçar estratégias para o estabelecimento de uma política nacional de iluminação pública. ${ }^{11}$

De acordo com o IBAM (1984), os municipios alegavam uma série de problemas institucionais, principalmente o "tratamento inadequado" dispensado pelas concessionárias contratadas para implantação e manutenção da iluminação pública, e a escassez de recursos financeiros para o custeio desses serviços.

Nesse encontro, a principal proposta apresentada pelos municipios para sanar os problemas financeiros foi a extinção da tarifa de energia elétrica de iluminação pública. Essa medida, na visão dos participantes, seria benéfica para os municípios, considerando que a iluminação pública estimula atividades noturnas e, conseqüentemente, proporciona maior faturamento para o comércio e o turismo.

\footnotetext{
11 Esse encontro, denominado O Município e a Iluminação Pública, foi promovido pelo IBAM no Rio de Janeiro entre os dias 25 e 26 de outubro de 1984.
} 
Outra proposta foi a cobrança de uma taxa às concessionárias pela utilização do solo por seus equipamentos de distribuição de energia elétrica, tais como postes e redes (IBAM, 1984).

\section{A mediação do DNAEE}

Os cinco primeiros anos da década de 80 foram marcados por intensas discussões acerca dos serviços de iluminação pública, o que se comprova pela mobilização das concessionárias e dos municípios.

As freqüentes pressōes, promovidas sobretudo pelas concessionárias, ensejaram a criação de um Grupo de Estudos pelo DNAEE com o objetivo de mediar os conflitos entre municipios e concessionárias. O grupo teria a finalidade de buscar soluçōes conciliatórias para os problemas de propriedade das instalaçōes dos sistemas de iluminação pública, propor mecanismos para uniformização dos serviços e sua remuneração, e estabelecer diretrizes de políticas para o setor. ${ }^{12}$

Com base num diagnóstico que envolveu 45 concessionárias, constatou-se a seguinte situação:

- patrimônio das instalacões de iluminação pública: em 19 casos as concessionárias eram proprietárias das instalações; em 18, as prefeituras e, em 8, ambas;

- lâmpadas e instalações especiais: $50 \%$ das lâmpadas instaladas eram de propriedade das concessionárias. As instalações dos sistemas de iluminação especial (diferente dos padrões das concessionárias), em 37 dos casos pertenciam às prefeituras municipais; 
- participação financeira nas obras de iluminaccão pública: somente cinco concessionárias participavam;

- critério de faturamento: todas as concessionárias pesquisadas estimavam o consumo com base no número de horas de funcionamento e na carga instalada do sistema de iluminação pública, com diferenças no número de horas a ser considerado por cada uma. Além disso, 18 concessionárias não incluíam as perdas nos reatores.

Diante desses resultados, as principais recomendações do Grupo foram as seguintes: a) não adotar uma alternativa única a curto prazo, considerando a diversidade de tratamento adotado pelas concessionárias; b) buscar a padronização das instalações de iluminação pública para promover a economia de escala e a racionalização do uso da energia elétrica nesse segmento e, c) estabelecer critérios uniformes para o cálculo estimado do consumo de energia elétrica para fins de faturamento.

Também deveriam ser definidos os critérios e procedimentos a serem adotados no caso das instalações de iluminação pública pertencentes às concessionárias, sem ferir a autonomia municipal. A recomendação no curto prazo foi estabelecer preços diferentes em função dos serviços prestados. No longo prazo se adotaria um tratamento único para o serviço de iluminação pública, visando conciliar os interesses das concessionárias e dos municípios.

\subsection{Regulamentação do fornecimento de energia elétrica para IP}

\section{A competência dos municípios para prestacão dos servicos de IP}

A autonomia municipal para organização e prestação dos serviços públicos de interesse local é um princípio constitucional consagrado desde a Constituição 
Federal de 1967 (MEIRELLES, 1988). A Constituição Federal do Brasil de 1988 não só preservou, mas ampliou essa prerrogativa ao estabelecer no seu artigo 30 , inciso $V$, que compete aos municipios "organizar e prestar, diretamente ou sob regime de concessão ou permissão, os serviços públicos de interesse local...". O DNAEE invocou esse preceito constitucional no preâmbulo da Portaria $N^{\circ} 158 / 89$, nos seguintes termos:

"Considerando que a Constituição Federal, no Capitulo IV, art. 30 , inciso $V$, define ser de competência do Município a organização e a prestação do serviço de iluminação pública"...

Ainda que o texto da Constituição Federal não cite explicitamente a iluminação pública como um serviço público de interesse local, essa interpretação parece não comportar dúvidas - pelo menos é o que se depreende da legislação e de pareceres de eminentes juristas brasileiros.

Só para citar um exemplo, Meirelles é incisivo ao afirmar que "o serviço de iluminação é da alçada municipal, por se conter, sem sombra de dúvida, na esfera do peculiar interesse do município - o aclaramento de ruas e logradouros públicos - e não se confundir com o serviço de energia elétrica e respectivas instalaçōes, esse sim, da competência da União" (MEIRELLES, 1988, p.267).

Ademais, vários municípios brasileiros definem a iluminação pública como um serviço de interesse local na Lei Orgânica Municipal, o que contribui decisivamente para dirimir controvérsias sobre a competência legal de sua prestação. 


\subsubsection{A Portaria DNAEE № $158 / 89$}

A Portaria DNAEE № $158 / 89$ foi editada levando em consideração todas as propostas do Grupo de Estudos criado em 1985. Nos seus doze artigos foram contemplados os temas mais polêmicos apontados na época, quais sejam: conceituação do serviço de iluminação pública; classificação e padronização dos sistemas de IP; definição do ponto de entrega; responsabilidade pelos investimentos; critérios para faturamento; responsabilidade pela operação e manutenção, e tarifas.

Ao longo de sua vigência, porém, a aplicação de alguns artigos a seguir discutidos, não tiveram a eficácia desejada e/ou se mostraram ambíguos, e foram sendo freqüentemente interpretados ao sabor e conveniência ora das prefeituras, ora das concessionárias.

\section{Classificacão e padronizacão da iluminacão pública}

Foram definidas duas categorias de sistemas de iluminação pública: padronizada e especial. A iluminação pública padronizada é aquela cujas instalaçōes estão em conformidade com as normas e padrōes da concessionária e com os níveis de iluminância definidos nas normas da ABNT. Em outras palavras, trata-se da iluminação convencional de ruas, instalada nos próprios postes da rede de distribuição da concessionária de energia elétrica, devendo ser ela a responsável pelos serviços de manutenção e seus respectivos custos.

A segunda categoria, iluminação pública especial, é assim definida pelo fato das instalações serem diferentes dos padrões adotados pela concessionária e/ou porque os níveis de iluminância produzidos excedem aos estabelecidos nas normas da ABNT. Trata-se da iluminação ornamental ou decorativa de praças e 
outros logradouros públicos, e de vias e avenidas importantes, situações em que o município não só tem autonomia e interesse de implantar uma iluminação diferenciada, mas porque tecnicamente pode ser recomendável, em função da largura da via, complexidade e volume de tráfego de veículos e pedestres.

Entretanto, essas duas classificações têm gerado polêmicas. A primeira, porque os municípios alegam que os critérios de padronização do sistema de IP são estabelecidos de maneira unilateral pelas concessionárias, o que fere o principio da autonomia municipal com relação aos serviços de iluminação pública; a segunda, porque a Portaria ao vincular o valor da tarifa aos niveis de iluminância produzidos e aos tipos de material empregado pela prefeituras municipais, ensejou a cobrança de uma tarifa mais elevada do que a aplicada aos sistemas de iluminação pública padronizada. ${ }^{13}$

\section{Responsabilidade pelos servicos de operacão e manutencão}

A responsabilidade pelos serviços de operação e manutenção de iluminação pública e os seus respectivos custos, leva em conta a propriedade do sistema e o ponto de entrega da energia elétrica. $O$ ponto de entrega pode ser, alternativamente, a conexão da rede de distribuição da concessionária com as instalações do sistema de iluminação pública, quando a propriedade das instalações de iluminação pública é da prefeitura; ou o bulbo da lâmpada, quando a propriedade das instalações é da concessionária.

No primeiro caso a concessionária é simplesmente a fornecedora de energia elétrica, sendo de responsabilidade da prefeitura municipal os serviços de operação e manutenção e seus respectivos custos. No segundo, as

13 Os tipos de tarifas praticados na iluminação pública são analisados no item 3.3 .1 do capítulo 3 . 
concessionárias é que são as responsáveis pelos serviços de manutenção, inclusive seus custos.

No caso dos sistemas especiais, o ponto de entrega será na conexão da rede de distribuição da concessionária com as instalações de iluminação pública, que nesse caso devem ser sempre de propriedade do município. A Figura 2.7 ilustra a localização do ponto de entrega na iluminação pública.

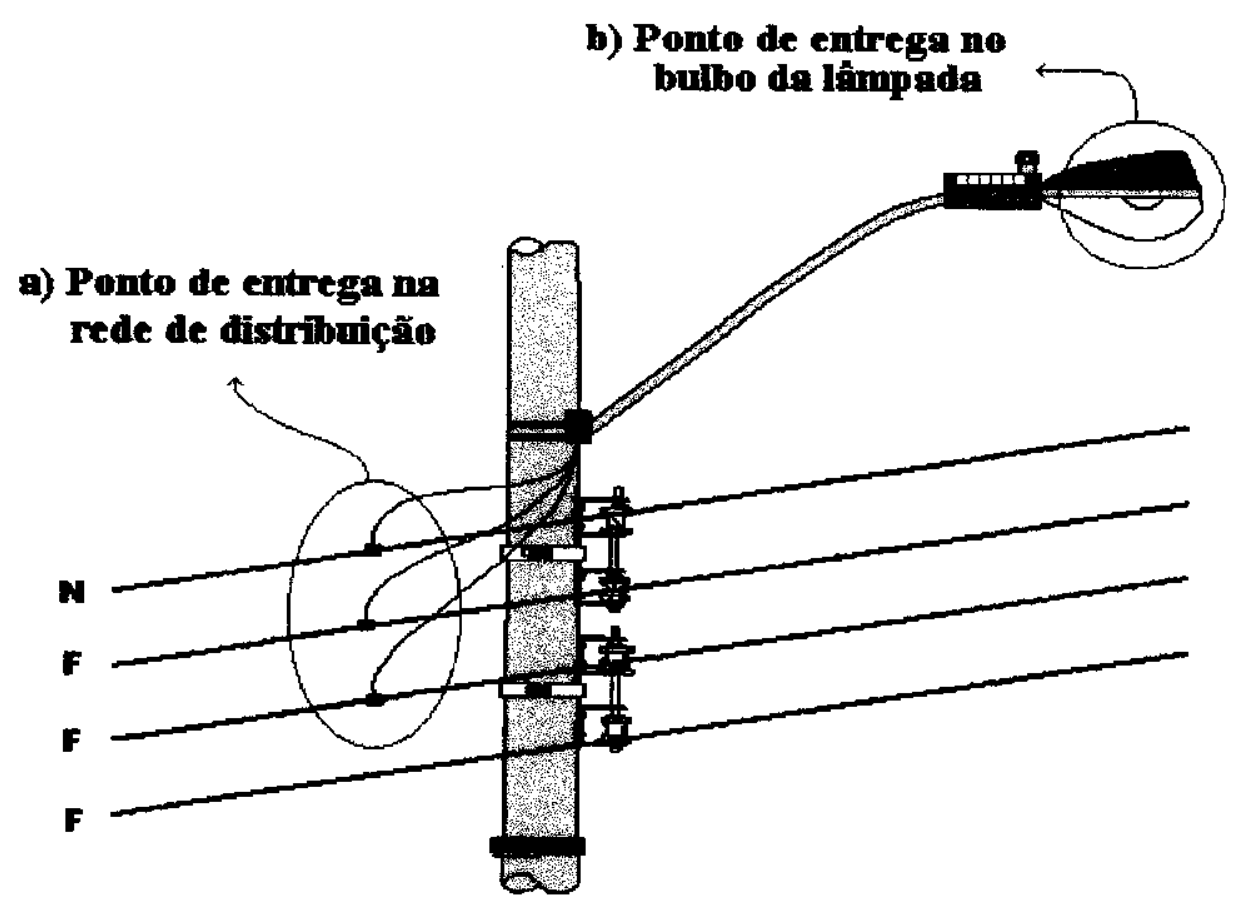

Figura 2.7 Ponto de entrega na iluminação pública.

Fonte: BARBOSA ; ALMEIDA (1998, p.15).

(Legenda: $\mathbf{N}=$ neutro, $\mathrm{F}=$ fase).

A alternativa do ponto de entrega no bulbo da lâmpada visou assegurar a remuneração dos serviços de manutenção, por meio da tarifa, nos casos de instalações de iluminação pública pertencentes às concessionárias. Entretanto existem casos em que o ponto de entrega se situa no bulbo da lâmpada, sem que 
a concessionária seja a proprietária do sistema de iluminação pública, e ainda a interpretação de que essa modalidade tarifária é uma opção a ser negociada entre as partes (PMJP, 1997).

\section{Faturamento do consumo de energia elétrica na iluminacão pública}

A concessionária não é obrigada a instalar equipamentos para medir o consumo de energia elétrica da iluminação pública. Nesse caso, os valores de energia e/ou demanda de potência ativas podem ser estimados, para fins de faturamento, com base no período de consumo e na carga instalada, incluída a carga própria dos equipamentos auxiliares (reator/ignitor).

O número mensal de horas adotado como período de consumo de energia elétrica é de 360 (trezentos e sessenta). Ou seja, considera-se que a iluminação pública fica ligada em média 12 horas por dia, durante trinta dias, totalizando 360 (12 X 30) horas, ou 4.320 hora/ano. Porém nem todos os municípios concordam ou aceitam esse critério e questionam a exatidão desse número. Do mesmo modo, algumas concessionárias discordam das 360 horas como período de consumo mensal, sob a alegação de que por esse critério deixam de faturar o consumo de energia elétrica durante 60 horas/ano.

Sobre essa questão o CODI formulou consulta ao Instituto de Astronomia e Geofísica (IAG) da Universidade de São Paulo (USP). Em sua resposta o IAG informou que a luminosidade natural varia com a posição geográfica (latitude), períodos e estações do ano e de acordo com as condiçōes meteorológicas locais. No Brasil, cujo território se encontra na faixa de latitude que vai de $-35^{\circ} \mathrm{S}$ e $+10^{\circ} \mathrm{N}$, a média anual diária de tempo entre o nascer e o ocaso do sol, 12 horas, é um valor razoável para ser adotado como referência na iluminação pública para fins de faturamento de energia elétrica (CODI, 1984). 
Entretanto, este critério por si só não é suficiente para dirimir as controvérsias uma vez que os relés fotelétricos que acionam a iluminação pública são calibrados para atuarem de acordo com os indices de iluminância globais, em lux, verificados durante o nascer e o ocaso do sol.

Portanto, seria necessário medir, em cada cidade, os níveis de iluminância produzidos durante esses dois eventos, no mínimo, no periodo de um ano. Por outro lado, adotar rigorosamente este procedimento parece não ser a maneira mais prática de solucionar a questão, pois a faixa de latitude em que se encontra o Brasil conduz a estimativas de que na maioria dos municipios, os resultados se enquadrariam no critério atualmente adotado.

Outra questăo controversa são os critérios utilizados para definir os valores das perdas nos reatores. Algumas concessionárias não consideram os dados fornecidos pelos fabricantes e adotam os valores das normas da ABNT para ensaio desses equipamentos, que estabelecem os valores máximos de referência. Esse procedimento pode penalizar as prefeituras municipais com o aumento da fatura do consumo de energia elétrica, motivada pelo acréscimo indevido de potência (carga) instalada.

\subsubsection{A Portaria DNAEE № $466 / 97$}

A Portaria DNAEE 466/97, que estabelece as condições gerais de fornecimento de energia elétrica e os critérios de relacionamento entre a concessionária e os consumidores na prestação e utilização de serviço público de energia elétrica, apresenta vários artigos destinados especificamente à iluminação pública e à prefeitura municipal, como um consumidor. ${ }^{14}$ 


\section{Consumidor e a unidade consumidora}

A Portaria 466/97 define consumidor como sendo a pessoa física ou juridica, legalmente representada, que solicita à concessionária o fornecimento de energia elétrica e assume a responsabilidade pelo pagamento das contas e demais obrigações legais, regulamentares e contratuais. No caso da iluminação pública, quando não existe uma empresa municipal de iluminação pública, essa responsabilidade geralmente é atribuída a uma das Secretarias Municipais ou órgão a que os serviços sejam subordinados.

O pedido de fornecimento de energia elétrica para os sistemas de iluminação pública deve ser efetuado formalmente à concessionária pela prefeitura municipal, que neste ato deve assegurar que as instalações elétricas de iluminação pública estão de acordo com as normas da ABNT e da concessionária. O fornecimento de energia elétrica caracteriza negócio jurídico e é obrigatória a celebração, por escrito, de contrato de fornecimento entre a prefeitura municipal e a concessionária.

Com relação à unidade consumidora, a Portaria 466/97 estabelece que ela se caracteriza pelo recebimento de energia elétrica em um só ponto, por ter medição individualizada e corresponder às instalações de um único consumidor. No caso da iluminação pública a aplicação direta dessa definição fica prejudicada, pois os sistemas de IP se caracterizam por receberem energia elétrica em vários pontos. No caso do ponto de entrega no bulbo da lâmpada, a rigor, poderia imaginar-se cada lâmpada como sendo uma unidade consumidora (BARBOSA ; ALMEIDA, 1998).

Nos casos dos sistemas em que a instalação de equipamentos de medição é técnica e economicamente viável, e nos casos do ponto de entrega na rede de distribuição, não seria inadequado definir a unidade consumidora como sendo um circuito ou subsistema de iluminação pública que atende uma área, avenida ou 
praça, por exemplo. Isto, aliás, é que o que se verifica pelo procedimento de faturamento das próprias concessionárias.

\section{Renegociação do contrato de fornecimento}

Para incentivar o combate ao desperdício de energia elétrica, o artigo 22 da Portaria DNAEE 466/97 prevê a renegociação dos contratos de fornecimento dos consumidores que efetivamente adotarem açōes nesse sentido:

"A concessionária deverá renegociar, a qualquer tempo, os contratos de fornecimento de energia elétrica, sempre que solicitados por consumidores que implementarem medidas de conservação, de incremento à eficiência e ao uso racional da energia elétrica, comprováveis pela concessionária, que resultem em redução de demanda de potência e ou de consumo de energia elétrica ativa, observada a regulamentação específica".

\section{Obrigacões da concessionária}

Os principais compromissos das concessionárias junto aos consumidores e suas obrigações com relação à qualidade do fornecimento de energia são os seguintes:

- estabelecer um prazo de 15 (quinze) dias para vencimento das contas de iluminação pública, contados da data da respectiva apresentação;

- fornecer energia elétrica com continuidade, eficiência e segurança;

- praticar tarifas com preços módicos, informando sempre os valores em vigor, o número e a data da Portaria que as houver estabelecido;

- manter exemplares das Portarias que regulamentam os serviços de energia elétrica em seus escritórios e locais de atendimento, para conhecimento ou consulta dos consumidores; 
- prestar informaçōes aos consumidores, individualmente ou aos Conselhos de Consumidores;

- manter em todos os seus postos de atendimento, em lugar visivel, livro próprio para possibilitar a manifestação por escrito dos seus consumidores;

- disponibilizar aos consumidores suas normas e padrões.

\subsubsection{A revisão da Portaria DNAEE № $158 / 89$}

\section{Situacão atual dos servicos de iluminacão pública}

Decorridos cerca de dez anos da edição da Portaria DNAEE 158, o contexto institucional do país e, particularmente do setor elétrico, é bastante diferente. Atualmente verifica-se o processo inverso ao ocorrido nos anos 40: a mudança do controle das empresas de energia elétrica, de estatal para privado - ou, a privatização do setor elétrico brasileiro.

Nota-se também o crescimento da autonomia municipal conferido pela Constituição Federal de 1988, principalmente quanto à prestação dos serviços de interesse local, no qual se insere a iluminação pública. Este fato pode ser revelado pelo aumento do poder de mobilização dos municípios com a criação de uma entidade em âmbito nacional, a CONLUX - Comissāo Nacional de lluminação Pública, com o objetivo de defender os interesses dos municipios nesse setor. ${ }^{15}$

Em que pese a mudança de cenário, muitas das situações verificadas em 1985 ainda perduram, tais como os problemas relacionados com a propriedade do sistema de IP e a inadimplência no pagamento das faturas de energia elétrica, só para citar dois exemplos. Ademais, algumas empresas privatizadas provavelmente

15 A CONLUX foi criada através do manifesto Carta do Rio, lançado no dia 25/07/97, por ocasião do I Seminário Internacional de Iluminação Pública, realizado no Rio de Janeiro durante os dias 23, 24 e 25/7/97. 
para minimizar as perdas financeiras geradas pela inadimplência dos municipios, têm demonstrado pouco interesse em continuar prestando os serviços de manutenção do sistema de iluminação pública.

Uma pesquisa realizada pelo PROCEL em convênio com o IBAM, revelou que os serviços de iluminação pública continuam sendo executados diretamente tanto por concessionárias quanto pelos municipios. Quanto ao patrimônio das instalações, a participação de ambos também é equilibrada, conforme mostram os gráficos das figuras 2.8 e 2.9 , respectivamente (IBAM, 1997). ${ }^{16}$

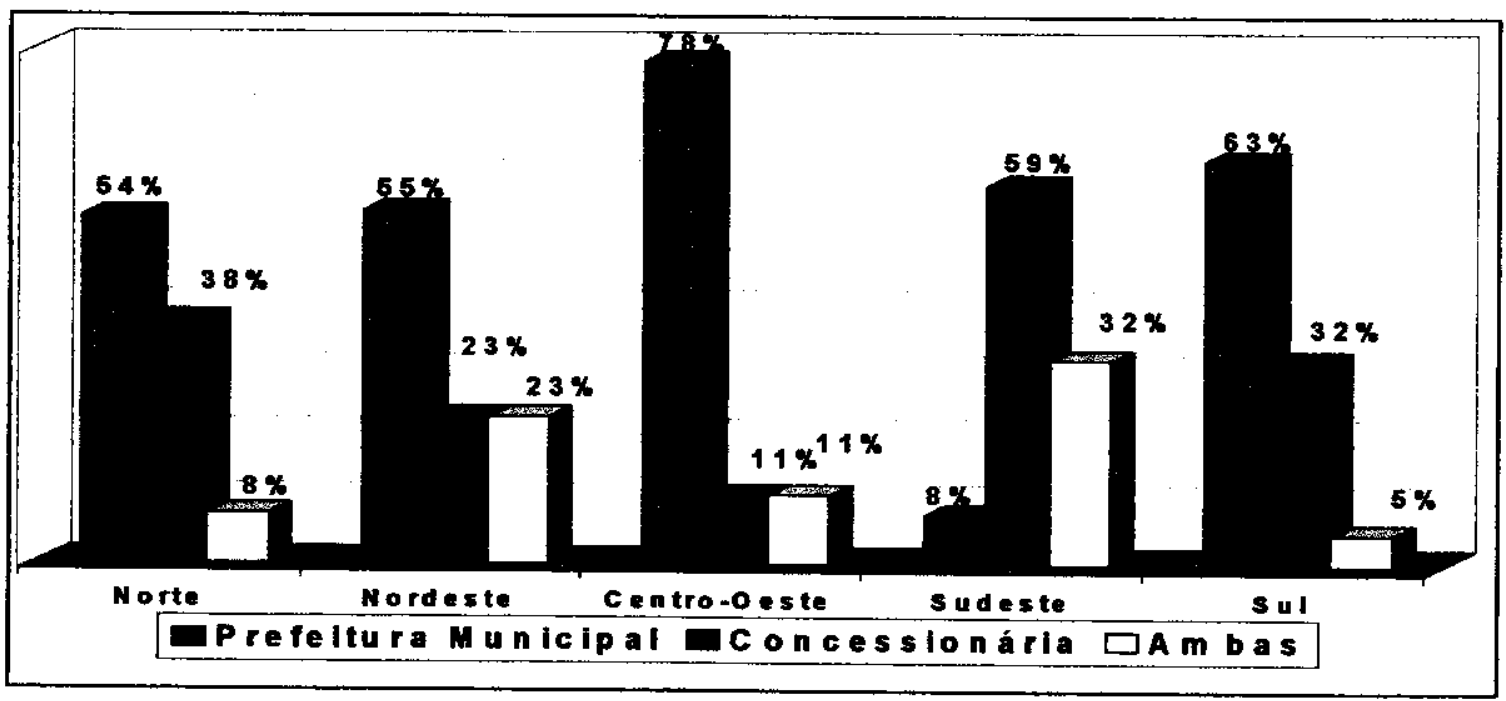

Figura 2.8 Prestadores dos serviços de iluminação pública por região. Fonte: IBAM/PROCEL (1997).

160 universo da pesquisa compreendeu 461 municípios brasileiros com população superior à 50.000 habitantes, segundo o censo de 1991 do IBGE, dos quais 170 responderam ao questionário no periodo de fevereiro a junho de 1997. 


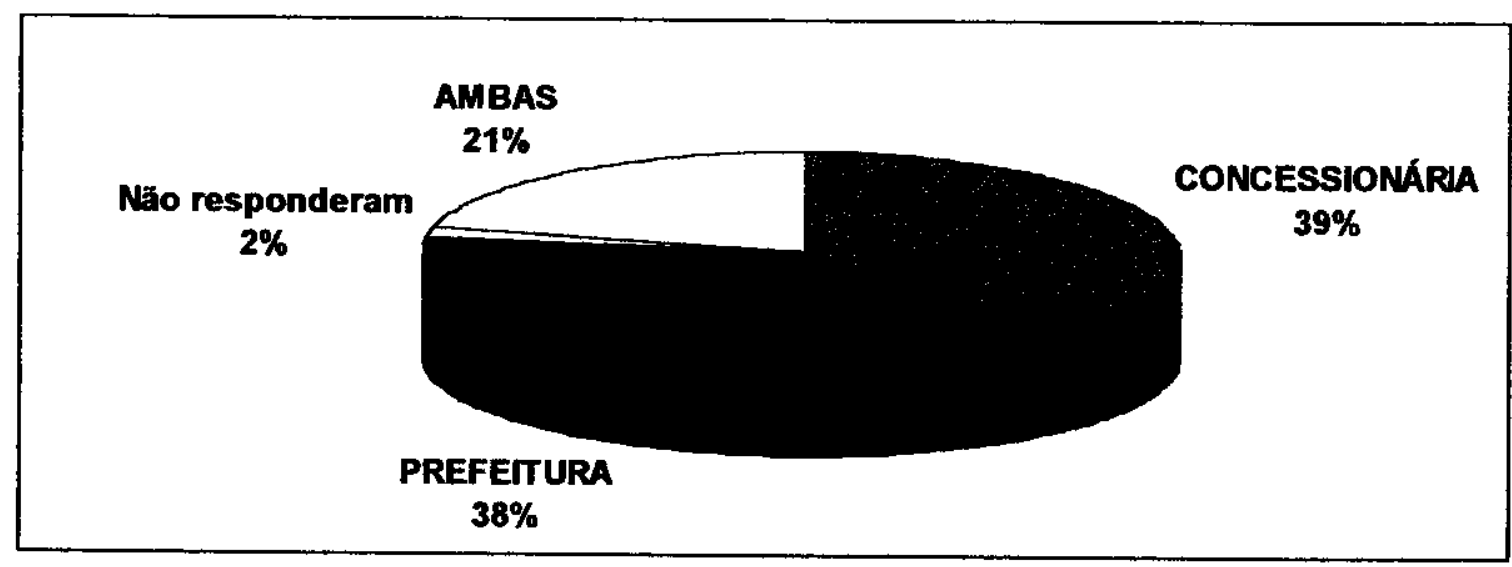

Figura 2.9 Propriedade das instalações de iluminação pública. Fonte: IBAM/PROCEL (1997).

\section{As principais mudancas propostas na revisão da Portaria DNAEE 158/89}

Diante dos constantes problemas surgidos com a Portaria DNAEE 158/89, a ANEEL criou um Grupo de Trabalho para revisá-la. As principais mudanças propostas na minuta de Resolução ainda a ser editada, são analisadas a seguir:

1. Serāo extintas as definiçōes de iluminação pública padronizada e iluminação pública especial.

2. Será ampliado o rol de logradouros públicos a serem classificados para fins de faturamento de energia elétrica destinada à iluminaçăo pública, com a inclusão de passagens subterrâneas, passarelas, abrigos de usuários coletivos, e ainda monumentos, fachadas, obras de arte de valor histórico cultural ou ambiental e fontes luminosas, localizadas em áreas públicas.

3. A tarifa B4C deverá ser extinta nos moldes em que atualmente é cobrada (com base nos niveis de iluminância produzidos pelo sistema e nos tipos de material empregado) e passará a vigorar somente nos casos em que o municipio, nos sistemas de sua propriedade sob manutenção da concessionária (ponto de 
entrega no bulbo da lâmpada), deseje utilizar materiais diferentes dos padrões normalmente empregados por esta.

A diferença substantiva é que tal possibilidade será facultativa, ou seja, se o município não quiser incluir a manutenção desse sistema nos serviços prestados pela concessionária, ela mesma será a responsável, inclusive pelos custos, e a tarifa a ser cobrada será a B4a (referente apenas ao fornecimento de energia elétrica).

4. Será obrigatória a celebração de contrato de fornecimento entre concessionárias e os municípios para definição das condições gerais e critérios de prestação dos serviços.

5. No faturamento da energia elétrica será facultada a negociação, entre a concessionária e o município, do número de horas de funcionamento do sistema de iluminação pública e dos valores de perdas nos equipamentos auxiliares (reator/ignitor).

6. A concessionária será obrigada a considerar para fins de faturamento, a redução de consumo de energia elétrica proporcionada por equipamentos de controle automático de potência fornecida aos reatores/ lâmpadas.

\subsection{Conclusões}

A análise do contexto histórico-institucional sobre os serviços de iluminação pública revela que os principais conflitos existentes entre concessionárias e municípios, são relacionados com a propriedade das instalações do sistema de iluminação pública, a competência legal para prestação dos serviços e a inadimplência no pagamento das contas de energia elétrica. 
A iluminação pública é um serviço essencial para os centros urbanos pois contribui para a segurança pública, melhoria da imagem e criação de uma identidade noturna para as cidades. Além disso, estimula a prática de esporte, lazer e trabalho nos logradouros públicos, proporcionando mais tempo de convívio social para comunidade.

As normas brasileiras sobre iluminação pública - NBR 5101, estabelecem, como requisitos de segurança para iluminação pública de vias com tráfego de veículos $\mathrm{e}$ de pedestres, niveis médios mínimos de iluminância e fator de uniformidade, de acordo com o tipo e o volume de tráfego na via.

O fornecimento de energia elétrica para iluminação pública é regulamentado pelas Portarias DNAEE No 466/97 e No 158/89. Esta última apresenta artigos polêmicos relacionados com a classificação dos sistemas em iluminação padronizada $\mathrm{e}$ especial, definição de responsabilidade pelos custos de manutenção, critérios para faturamento da energia elétrica consumida e tarifas.

A nova regulamentação sobre iluminação pública, a ser editada pela ANEEL, amplia a classificação de logradouros a serem tarifados como IP, faculta a negociação do número de horas de funcionamento do sistema e dos valores de perdas nos reatores, e obriga a renegociação do contrato de fornecimento em função da redução de carga proporcionada por equipamentos automáticos de controle do consumo de energia elétrica.

Com a edição da nova Resolução, espera-se que os históricos confitos entre concessionárias de energia elétrica e prefeituras municipais sejam efetivamente superados ou minimizados, e que os serviços de iluminação pública sejam prestados com melhor qualidade e eficiência. 


\section{AS TARIFAS DE ENERGIA ELÉTRICA PARA ILUMINAÇÃO PÚBLICA E A TAXA DE ILUMINAÇÃO PÚBLICA}

\subsection{A política tarifária brasileira: uma breve retrospectiva histórica}

\section{Das tarifas reajustadas pelo ouro às tarifas com base no custo do servico}

Desde a instauração da Republica, até pelo menos a metade do século $X X$, a indústria de energia elétrica no Brasil foi monopolizada por grupos estrangeiros (CME, 1988). Durante esse período, caracterizado por crises econômicas mundiais e pela forte influência ideológica da Europa sobre os Estados em formação, teve início o processo de regulamentação dos serviços de energia elétrica do país e, particularmente, a definição dos critérios de fixação e reajustes das tarifas (LIMA, 1995). ${ }^{17}$

Constata-se, a princípio, que a política de expansão do setor elétrico brasileiro com base no autofinanciamento e, posteriormente, por meio de empréstimos externos, teve nas tarifas as suas mais controvertidas e polêmicas decisões (JOHNSON et al, 1996). Isto se revela pelos sucessivos atos de criação de impostos, quotas e outros mecanismos de transferência intrasetorial, que nem sempre tiveram eficácia.

Um dos primeiros instrumentos de regulamentação dos serviços de energia elétrica no Brasil foi o Decreto 5.407 de 1904, que previa a revisão das tarifas com base na variação cambial através da "cláusula ouro". Ou seja, metade do pagamento em papel-moeda e metade em valores-ouro, ao câmbio do mês de

\footnotetext{
17 "A crise do capitalismo em escala mundial abalou os pilares do liberalismo econômico, suscitando um novo perfil de intervenção do Estado norte-americano (New Deal) e dando lugar à polarizaçāo das tendências político-ideológicas na Europa: de um lado o nazifascismo e, de outro, o socialismo" (LIMA, p.18).
} 
consumo. Esse mecanismo foi extinto em 27 de novembro de 1933, com a edição do Decreto 23.501 (CME, 1988).

Segundo LIMA (1995, p.23) "ao retirar a possibilidade do reajuste tarifário em função das desvalorizações cambiais, o governo federal impunha novas regras para os contratos de concessão, assumindo o domínio sobre a fixaçāo das tarifas de energia elétrica, ainda que sem as bases legais do Código de Aguas".

O Código de Águas foi publicado em 23 de julho de 1934 e estabeleceu que as tarifas deveriam ser fixadas sob a forma de serviço pelo custo, levando em conta as despesas de operação, as reservas para depreciação e reversão e ainda a "justa remuneração do capital", que seria avaliado pelo custo histórico das instalaçōes. A Lei 3.128 de 19 de março de 1941, que regulamentou o Código nesse aspecto, definiu que a base de remuneraçāo seria uma conta do ativo da concessionária, avaliado em função do custo histórico do serviço.

Porém, as concessionárias se posicionaram contra a aplicação desse critério, sob o argumento de que num regime de instabilidade monetária e inflação, o patrimônio em serviço seria avaliado abaixo do valor real, o que resultaria no estabelecimento de níveis tarifários que não permitiriam remunerar adequadamente o capital investido, nem autofinanciar o setor.

De fato, o critério do custo histórico nunca chegou a ser totalmente adotado e a Lei $3.128 / 41$ só foi regulamentada em 4 de novembro de 1964 por meio do Decreto 54.936, que tornou obrigatória a aplicação da correção monetária ao valor original dos bens do ativo imobilizado das concessionárias de energia elétrica e fixou a remuneração de no mínimo $10 \%$ sobre o capital investido. Dessa forma, com o aumento do custo do serviço, as margens de autofinanciamento das empresas também cresceram (CME, 1988). 
Ainda no dia 4 de novembro de 1964 foi editado o Decreto $n^{\circ} 54.937$, que determinou o tombamento do patrimônio das concessionárias para definição do investimento remunerável. Em 20 de maio de 1971, a Lei 5.655 autorizou a elevação da taxa mínima de remuneração legal de $10 \%$ para $12 \%$ e reduziu a aliquota do imposto de renda sobre os lucros das empresas de $17 \%$ para $6 \%$ (LIMA, 1995).

Para JOHNSON et al (1996, p 63) "não é exagero afirmar que as principais determinações do Código de Águas referentes ao controle das concessionárias de energia elétrica jamais foram aplicadas. Nem o 'custo histórico' das instalações foi levantado, nem a tarifa foi calculada para remunerar o investimento à taxa de $10 \%$. Houve, na prática, uma acomodação entre o Governo Federal e as concessionárias que permitiu a estas manter rentabilidade satisfatória".

\section{A eqüalização tarifária}

Até 1974 as tarifas de energia elétrica eram diferenciadas pelo custo do serviço de cada concessionária. Com os objetivos de promover o desenvolvimento regional do setor elétrico e otimizar os recursos de geração de longo prazo, o governo federal, por meio do Decreto-Lei 383 de 26 de dezembro de 1974, estabeleceu a eqüalizaçăo tarifária em todo o território nacional e limitou os reajustes de tarifas e preços públicos ao máximo de $20 \%$ a.a. Além disso, as concessionárias que apresentassem remuneração acima da média do setor estavam obrigadas a transferir recursos para as empresas deficitárias (CME, 1988).

Em 23 de dezembro de 1976 os critérios de cálculo do investimento remunerável foram alterados pelo Decreto-Lei 1.506, deixando de ser com base no saldo do exercício tarifário em 31 de dezembro de cada ano, e passando a ser pro-rata tempore, pelo valor médio. 
Ainda de acordo com LIMA (1995), sob o argumento de fortalecer os mecanismos de transferência interna do setor elétrico e considerando os niveis críticos em que se encontravam as tarifas, o governo federal editou em 13 de janeiro de 1981 o Decreto-Lei 1.849 , que elevou a incidência da quota de reversão de $3 \%$ para $4 \%$ sobre o investimento remunerável. Esse decreto também estabeleceu a projeção da remuneração média do setor, acima da qual o lucro da concessionária seria recolhido sob forma de quota de garantia.

\section{A reformulacão de 1993}

A partir de 1993 o setor elétrico sofreu uma importante reforma com a edição da Lei 8.631 de 4 de março de 1993. Essa lei extinguiu o regime de remuneração garantida e estabeleceu que os níveis das tarifas de energia elétrica deixariam de ser fixados diretamente pelo poder concedente, passando a ser propostos por cada concessionária para homologação deste.

Mais uma vez foi estabelecido que os niveis das tarifas deveriam corresponder aos valores monetários necessários à cobertura do custo do serviço para garantir a prestação de serviço adequado, segundo as características específicas de cada concessionária. O Decreto Lei $n^{\circ} 774$ de 18 de março de 1993, que regulamentou a Lei 8.631 , definiu os seguintes itens integrantes do custo do serviço:

a) pessoal e encargos sociais; b) material; c) serviços de terceiros; d) tributos, exclusive o imposto sobre a renda; e) despesas gerais; f) contribuiçöes e demais encargos não vinculados à folha de pagamento; g) energia elétrica comprada da ITAIPU BINACIONAL; h) energia elétrica comprada a outros supridores; i) transporte de energia elétrica da ITAIPU BINACIONAL; j) transporte de energia elétrica da ITAIPU BINACIONAL; k) quotas de reintegração, compreendendo depreciação e amortização; I) quotas para a Reserva Global de Reversāo - RGR; m) compensação financeira pela utilização de recursos hídricos; n) quotas das 
Contas de Consumo de Combustiveis Fósseis - CCC, para os respectivos sistemas interligados; o) quotas das Contas de Consumo de Combustiveis para os sistemas isolados - (CCC-ISOL); p) combustiveis utilizados na geração térmica, não reembolsáveis pela CCC; q) variação cambial excedente, segundo critérios aprovados; e r) remuneração.

Esse decreto também autorizou o processo gradual de recomposição das tarifas, proposto por cada concessionária, e a revisăo dos valores a cada três anos, com base numa fórmula envolvendo os parâmetros integrantes do custo do serviço.

\section{O atual modelo tarifário brasileiro}

A política tarifária do setor de energia elétrica brasileiro parece prosseguir na sua trajetória histórica, caracterizada pela indefinição de um referencial conceitual e pelas constantes mudanças de critérios na fixação dos niveis das tarifas. Constata-se também que o assunto é tratado em vários instrumentos legais, alguns, conflitantes entre si. Para comprovar esse fato, enumera-se os principais artigos de decretos e leis que tratam das tarifas de energia elétrica, com grifos nossos.

1. O Decreto $N^{\circ} 41.019$ de 26 de fevereiro de 1957, que regulamenta os serviços de energia elétrica, estabelece no seu Art 164, que as tarifas serão fixadas pelo regime do serviço pelo custo.

2. O Decreto $N^{\circ} 62.724$ de 17 de maio de 1968 , Art. 10 , determina que a fixaçāo da tarifa deverá ser instruída com base na análise do custo do serviço.

3. A Lei $N^{\circ} 8.631$ de 4 de março de 1993 , estabelece no seu Art. $1^{\circ}$ e parágrafo 20. 
"Art. $1^{\circ}$ - Os níveis de tarifas de fornecimento de energia elétrica a serem cobrados de consumidores finais serão propostos pelo concessionário, ao Poder Concedente, que os homologará".

Parágrafo $2^{\circ}$ - Os níveis das tarifas a que se refere o "caput" deste artigo corresponderão aos valores necessários para a cobertura do custo do serviço de cada concessionário distribuidor, segundo suas características especificas, de modo a garantir a prestação dos serviços adequados.

4. A Lei $N^{0} 8.987$ de 13 de fevereiro de 1995, que dispõe sobre o regime de concessão e permissão da prestação de serviços públicos previsto no art. 175 da Constituição Federal, estabelece no seu Art. $9^{\circ}$ e parágrafo $1^{\circ}$ :

"Art. $9^{\circ}$ - A tarifa do serviço público concedido será fixada pelo preço da proposta vencedora da licitacão e preservada pelas regras de revisão previstas nesta Lei, no edital e no contrato".

Parágrafo $1^{\circ}$ - "A tarifa não será subordinada à legislação especifica anterior e somente nos casos expressamente previstos em lei, sua cobrança poderá ser condicionada à existência de serviço público alternativo gratuito para o usuário".

5. A Lei $N^{\circ} 9.427$ de 26 de dezembro de 1996, que instituiu a ANEEL e disciplina o regime das concessões de serviços públicos de energia elétrica, estabelece nos seu Arts. 14 e 15 e, respectivamente, nos incisos I, e de I a IV:

"Art. 14 - O regime econômico e financeiro da concessão de serviço público de energia elétrica, conforme estabelecido no respectivo contrato, compreende":

I - a contraprestação pela execução do serviço, paga pelo consumidor final com tarifas baseadas no servico pelo preço, nos termos da Lei $N^{\circ} 8.987$, de 13 de fevereiro de 1995.

Art. 15 - Entende-se por servico pelo preço o regime econômicofinanceiro mediante o qual as tarifas máximas do serviço de energia elétrica serão fixadas:

I - no contrato de concessão ou permissão resultante de licitação pública, nos termos da Lei $N^{\circ}$ 8.987, de 13 de fevereiro de 1995. 
II- no contrato que promrogue a concessão existente, nas hipótese admitidas na lei 9.074, de 7 de julho de 1995.

III - no contrato de concessão celebrado em decorrência de desestatização, nos casos indicados no art. 27 da lei 9.074, de 7 de julho de 1995.

IV - em ato específico da ANEEL, que autorize a aplicação de novos valores, resultantes de revisão ou reajuste, nas condições do respectivo contrato.

Pela análise desse aparato legal é possivel destacar dois critérios para a fixação das tarifas de energia elétrica: serviço pelo custo e serviço pelo preço. Nos casos das empresas a serem privatizadas e nas novas concessōes, por exemplo, o artigo $9^{\circ}$ da Lei $N^{\circ} 8.987$ é claro ao estabelecer que as tarifas serão fixadas pelo preço da proposta vencedora da licitação e "não serăo subordinadas à legislação específica anterior". Isso significa que nem todas as concessionárias estarão submetidas às mesmas regras, o que pode gerar situações confusas e tratamento diferenciado na prestação de um mesmo tipo de serviço.

\section{Os atuais critérios de reajustes das tarifas de energia elétrica}

Atualmente as tarifas de energia elétrica são reajustadas em períodos anuais, um ano após a "Data de Referência Anterior" - DRA. Para o primeiro reajuste a DRA é a data de assinatura do contrato de concessão e para os subsequentes, a data de vigência do último reajuste ou revisão que o tenha substituído. $O$ reajuste tarifário é aplicado sobre a receita da concessionária, dividida em duas parcelas:

Parcela A: parcela da receita correspondente aos custos da quota da Reserva Global de Reversão - RGR; quotas da Conta de Consumo de Combustiveis - CCC; taxa de fiscalização do serviço; compra de energia elétrica para revenda; compensação financeira pela exploração de recursos hídricos para fins de geração de energia 
elétrica (quando aplicável) e encargos de conexão e uso das instalações de transmissão e distribuição de energia elétrica.

Parcela B: valor remanescente da receita da concessionária, excluído o ICMS, após a dedução da Parcela $A$.

O reajuste é calculado pela aplicação do Índice de Reajuste Tarifário (IRT), definido pela seguinte expressão:

$$
I R T=\underline{V^{\prime} A_{1}+V_{P B} \times(I V I \pm X)}, \text { onde }
$$

RA

- $\quad \mathbf{R A}=$ Receita anual, calculada considerando-se as tarifas homologadas da DRA e o "Mercado de Referência, não incluindo o ICMS. (Mercado de Referência - MR, é o mercado de energia assegurada da concessionária, nos 12 (doze) meses anteriores ao reajuste em processamento).

- $\quad$ IVI = Número índice obtido pela divisão dos índices do IGPM, da Fundação Getúlio Vargas, ou do índice que vier a sucedê-lo, do mês anterior à data do reajuste em processamento e do mês anterior à DRA.

- $X=$ Número indice, a ser subtraído ou acrescido ao IVI. Para os primeiros quatro reajustes anuais o valor de $X$ será zero.

- $\mathrm{VPB}_{0}=$ Valor da Parcela $\mathrm{B}$, considerando-se as condições vigentes na DRA e o MR.

$$
\mathrm{VPB}_{0}=\mathbf{R A}-\mathrm{VPA}_{0} \text {, onde }
$$


- $V_{P A}=$ Valor da Parcela A, considerando-se as condições vigentes na DRA e OMR.

- $\mathrm{VPA}_{1}=$ Valor da Parcela A, considerando-se as condições vigentes na data do reajuste em processamento e o MR.

A revisão dos valores das tarifas deve ser efetuada considerando as alterações na estrutura de custos e de mercado da concessionária, os niveis de tarifas de empresas similares nacionais e internacionais, e os estímulos à eficiência e à modicidade das tarifas. A primeira revisão deverá ser realizada um ano após o quarto reajuste anual concedido, e as subsequentes, a cada quatro anos. No processo de revisão das tarifas, o valor de $X$ deverá ser subtraído ou acrescido na variaçăo do IVI nos reajustes anuais subsequentes.

Numa análise sobre os critérios de reajuste tarifário, GUILLO ; SAUER (1999) ressaltam que o índice de correção escolhido, o IGP-M da Fundação Getúlio Vargas, pode gerar distorções econômicas, considerando que o índice da inflação é determinado por outro indicador, o IPC-A, medido pelo IBGE. Eles argumentam também que o fator $X$ não está definido com clareza $e$, portanto, não garante que os eventuais ganhos de produtividade das concessionárias sejam repartidos com a sociedade.

Outro aspecto a ser destacado é a comparaçāo das tarifas entre concessionárias. Embora sirva como um referencial, esse critério pode ser contestado em função da diversidade e peculiaridade das áreas de concessão. No Brasil, são significativas as diferentes caracteristicas de mercado, por exemplos: tipo, número de consumidores e concentração/dispersão; condiçōes técnicas do sistema elétrico; forma de suprimento; condições sócio-econômicas da área de concessão e nível de inadimplência dos consumidores, o que torna dificil estabelecer parâmetros equânimes de comparação. 
Uma prova é que quando tentou-se implementar o Plano de Modernização do Setor Elétrico - PMS, no início dos anos 90 , a recomendação era a de avaliar cada concessionária de acordo com as características intrínsecas do seu próprio mercado, e não com empresas congêneres de porte semelhante.

\subsection{Bases conceituais para definição das tarifas de energia elétrica}

Existem vários critérios e metodologias utilizados como referenciais teórico e conceitual na regulamentação econômico-financeira do serviço público de energia elétrica. Neste item serão analisados os conceitos do serviço pelo custo, historicamente adotado no Brasil, a regulação por preço teto incentivada e a teoria de custos marginais, que foi utilizada para definição da estrutura tarifária mas não teve continuidade.

\section{O servico pelo custo}

A regulamentação dos serviços públicos tem sido um assunto controvertido em quase todo o mundo, pois além de envolver opções teóricas e conceituais, está intimamente relacionada à questões políticas, econômicas, ideológicas e sociais de cada país.

JOHNSON et al (1996) consideram que o desenvolvimento de conceitos sobre a regulamentação econômico-financeira dos serviços de utilidade pública, sobretudo nos Estados Unidos, tiveram influência marcante para o aprofundamento das discussōes sobre a intervenção do Estado nos serviços de energia elétrica em vários países, inclusive no Brasil. 
Para eles o debate sobre a regulamentação dos serviços públicos nos Estados Unidos apresentou duas vertentes principais: o interesse público, inerente à essencialidade do serviço para a coletividade, e a sua caracterização como monopólio natural, condições suficientes para o Estado exercer a regulamentação com o objetivo de proteger os usuários da exploração financeira. ${ }^{18}$

Conforme apresentado no item 3.1, o Código de Águas estabeleceu que as tarifas de energia elétrica deveriam ser fixadas com base no critério do custo do serviço. Por outro lado, os críticos dessa metodologia argumentam que apesar de ser de fácil aplicação, a tarifação pelo custo do serviço não conduz aos objetivos desejados de alocação eficiente dos recursos e de repartição adequada dos custos entre os diversos grupos ou tipos de consumidores.

Nas palavras de BORN (1996, p.4), "exceto pelos objetivos de fixar preços 'justos e razoáveis', o sistema de tarifação pelo custo do serviço resume-se a um esforço administrativo para aplicar um fórmula muito simples, através de uma série de etapas". ${ }^{19}$

\section{A regulacão por preço teto incentivada}

Para GUILO ; SAUER (1999) a regulação por preço teto incentivada, desenvolvida com base no conceito principal-agente, minimiza os problemas da regulação pelo

\footnotetext{
18 A teoria econômica caracteriza como monopólio natural as situações em que uma única empresa atuando no mercado, consegue obter custos unitários de produção mais baixos do que várias empresas menores em regime de concorrència (JOHNSON et al (1996).

19 "(i) Os custos anuais de operaçăo, depreciação, impostos e taxas são somados; (ii) àquela soma é adicionado um lucro razoável, determinado pela aplicação de uma taxa de retorno ao capital imobilizado; este corresponde ao investimento em valores históricos, subtraído da depreciação acumulada até a data do cálculo da tarifa; (iii) o total até aqui fixado de forma a equalizar a receita bruta da empresa e seu requisito de receita; (iv) a estrutura tarifária é determinada, definindo a participação de cada classe de serviço e/ou consumidores na formação da receita total" (BORN, 1996, p.4).
} 
custo do serviço, pois estimula a produtividade das empresas e reduz a possibilidade de investimentos desnecessários. ${ }^{20}$

Pela fórmula do preço teto a tarifa pode ser aumentada anualmente com base num índice de preço no varejo RPI, que não é controlado pelo concessionário. Desse valor será abatido um percentual $X$, que representa a parcela de ganho de produtividade a ser transferido aos consumidores. O RPI garante reajustes com base no comportamento médio, no varejo, dos preços pagos pelos consumidores. Entretanto, eles reconhecem que esse critério não representa uma garantia de que os ganhos de produtividade sejam repartidos com a sociedade.

\section{A teoria dos custos marginais aplicada às tarifas de energia elétrica}

A escassez de recursos financeiros para investimentos na expansão do setor elétrico brasileiro, sobretudo nos anos 80 , causou riscos ao atendimento das crescentes demandas do mercado (DNAEE, 1985). De um lado, esse cenário impôs às concessionárias a implementação de ações emergenciais com a finalidade de minimizar os seus custos operacionais, e a adoção de medidas para incentivar uma melhor utilização das instalações por parte dos consumidores. De outro, proporcionou, a partir de 1977, as condiçōes favoráveis para o desenvolvimento de estudos sistematizados para definição da estrutura tarifária baseada na teoria dos custos marginais.

Para o DNAEE (1985), os fundamentos dessa teoria baseiam-se na premissa de que o mercado de energia elétrica apresenta demandas crescentes, em virtude da agregação de novos consumidores e/ou aumento do consumo dos existentes.

\footnotetext{
20 “A necessidade de evitar o comportamento monopolista das empresas exige intervenção pública. $O$ quadro de análise é formado por um arranjo do tipo principal-agente, onde o principal é o Estado ou agência reguladora e o agente é a empresa regulada" (GULLO ; SAUER, 1999).
} 
Isto significa que para manter o fornecimento de energia elétrica dentro de padrões adequados é necessária a ampliação do sistema elétrico, o que implica em custos adicionais para a sociedade.

Com base nessa teoria, portanto, é possivel calcular os custos de fornecer energia elétrica em qualquer ponto do sistema elétrico e num determinado período e hora do ano, determinando-se, para cada grupo de consumidores, a fração correspondente ao custo do serviço incorrido por eles.

Com a publicação do Decreto $N^{\circ} 86.463$ de 13 de outubro de 1981, o governo federal determinou que o DNAEE elaborasse estudos para estabelecer os critérios de repartição das parcelas do custo do serviço entre os componentes de demanda de potência e de consumo de energia, de acordo com a fração correspondente a cada grupo ou subgrupo de consumidores. Também autorizou a modificaçäo dos métodos de medição e de faturamento, considerando os períodos do ano, os horários de utilização da energia ou sua destinação (DNAEE, 1985). ${ }^{21}$

\section{Os princípios das tarifas baseadas nos custos marginais}

A tarifação baseada nos custos marginais se apoia em três princípios básicos. $O$ primeiro é neutralidade: o nível de preço da tarifa deve refletir o custo real dos serviços; o segundo é igualdade: grupos de consumidores com características de consumo semelhantes devem pagar de acordo com a mesma base tarifária; 0 terceiro é eficácia: as tarifas devem atingir objetivos econômicos e sociais, e proporcionar benefícios a todos os agentes, com a melhor utilização das instalações e racionalização do consumo de energia elétrica.

\footnotetext{
21 Este Decreto alterou o Decreto 41.019, de 26 de fevereiro de 1957, que regulamenta os serviços de energia elétrica e, o Decreto $n^{\circ}$ 62.724, de 17 de maio de 1968, que estabelece normas gerais de tarifação para empresas concessionárias de serviços públicos de energia elétrica e dá outras providências.
} 
A aplicação dessa metodologia exige $\circ$ conhecimento detalhado do comportamento da carga e dos custos marginais nos diversos niveis do sistema elétrico para determinar-se as tarifas de referência. A partir dos valores das tarifas de referência, são analisadas as restriçōes políticas, sociais, financeiras e operacionais, o que permite definir o nivel de preço final aos consumidores - as tarifas de aplicação. A figura 3.1 mostra um fluxograma que resume as etapas da metodologia do DNAEE para determinaçäo das tarifas baseadas nos custos marginais.

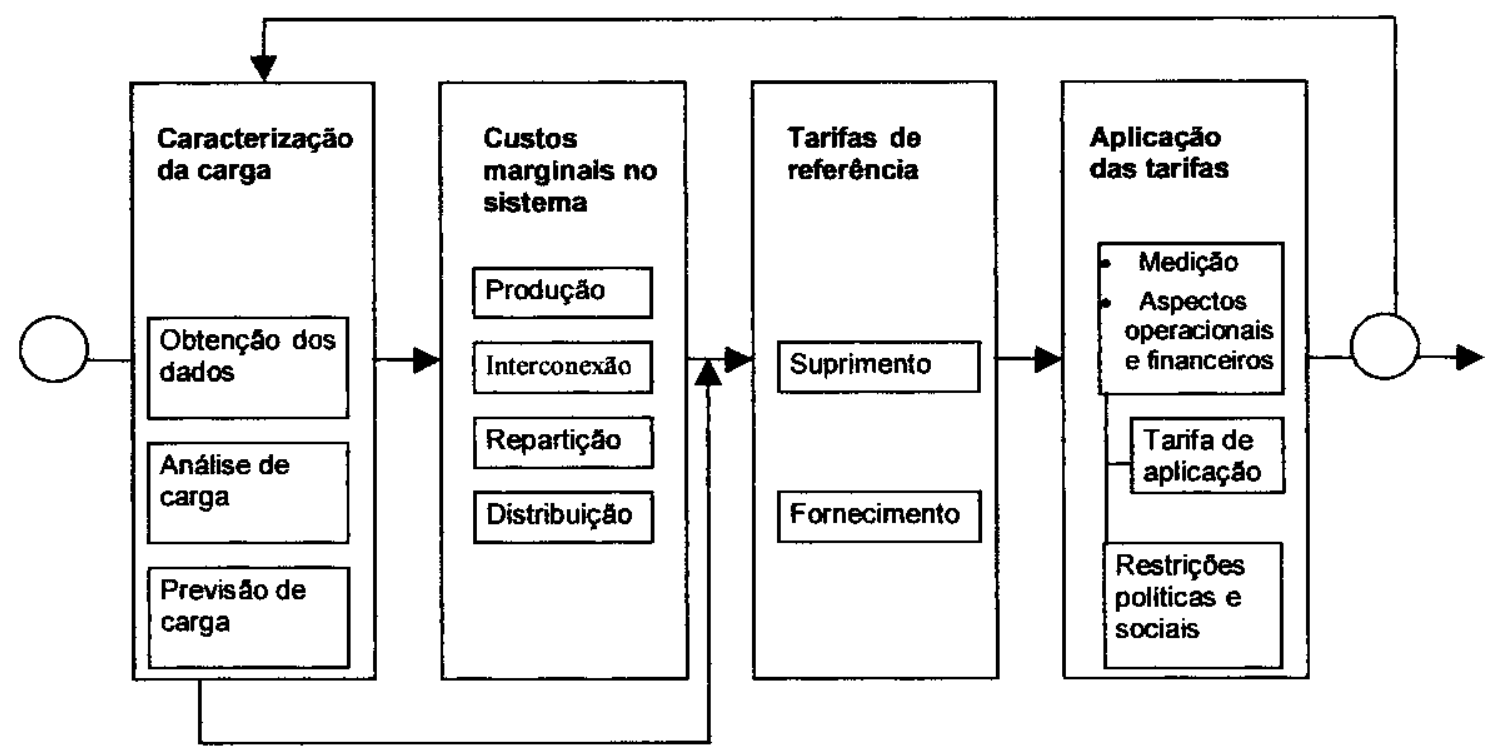

Figura 3.1 Fluxograma das tarifas baseadas nos custos marginais.

Fonte: DNAEE (1985).

Um ponto importante, ressaltado por BORN (1996), é que os custos marginais se constituem num método adequado para definir a estrutura tarifária e alocar os recursos de maneira eficiente, mas nem sempre são recomendáveis para estabelecer os níveis das tarifas. 
No APÊNDICE B, apresenta-se um exemplo de aplicação da metodologia dos custos marginais adaptada pelo DNAEE, com o cálculo da tarifa de referência de iluminação pública.

\subsection{Os tipos de tarifas aplicados à iluminação pública}

A Portaria DNAEE 158/89 define três tipos de tarifas aplicáveis ao fornecimento de energia elétrica para iluminação pública: tarifas B4a, B4b e B4c. Elas devem ser aplicadas de acordo com a localização do ponto de entrega de energia elétrica, a propriedade das instalaçōes e os niveis de iluminância produzidos pelo sistema de iluminação pública.

Aplica-se a tarifa B4a quando o ponto de entrega é na conexão do sistema de distribuição da concessionária com as instalações de iluminação pública; a B4b, quando o ponto de entrega é no bulbo da lâmpada, e, a tarifa B4c, no caso de fornecimentos realizados a instalações de iluminação pública especial e/ou que excedam os niveis de iluminância definidos nas normas da ABNT.

Por exemplo, se o municipio é proprietário do sistema de iluminação pública e também executa os serviços de operação e manutenção, o ponto de entrega deve ser na conexão da rede de distribuição. Nesse caso, a tarifa aplicada pela concessionária deve ser a $\mathrm{B} 4 \mathrm{a}$, referente apenas ao fornecimento de energia elétrica. Esta tarifa é a de menor preço entre os três tipos praticados.

Se a concessionária é a proprietária das instalaçōes de iluminação pública, o ponto de entrega deve ser no bulbo da lâmpada. Nesse caso ela é responsável pelos serviços de manutenção do sistema de IP e deve aplicar a tarifa B4b que, além dos custos com fornecimento de energia elétrica, inclui os de manutenção. Nos casos dos sistemas especiais, as instalações devem pertencer às prefeituras 
municipais e a concessionária poderá cobrar a tarifa B4c, que é a de maior valor entre os três tipos. ${ }^{22}$

A tarifa B4b foi a solução encontrada pelo DNAEE para resolver os problemas dos custos de manutenção, no caso de sistemas de iluminação pública de propriedade das concessionárias (na época da eqüalização tarifária). Para incentivar a racionalização do uso de energia elétrica na iluminação pública, foi criada a tarifa B4C.

\section{A dimensão financeira do faturamento do consumo de energia elétrica na IP}

O faturamento de sessenta e duas concessionárias com o fornecimento de energia elétrica para iluminação pública no mês de abril de 1998, representou cerca de 59 milhōes de reais, conforme tabela 3.1 .

TABELA 3.1 Consumo e faturamento mensais da IP por subgrupo tarifário.

\begin{tabular}{|c|c|c|c|c|}
\hline \multirow{2}{*}{ TARIFA } & \multicolumn{2}{|c|}{ EOLSUID } & \multicolumn{2}{|c|}{ FATRE ITIO } \\
\hline & (MWh) & $(\%)$ & (R\$) & $(\%)$ \\
\hline B45 & 443 & $62 \%$ & 35.865 .921 & $62 \%$ \\
\hline B4I & $24 \varepsilon$ & $35 \%$ & 19 & $33 \%$ \\
\hline$B 4 C$ & 21.782 & $3 \%$ & 2.748.247 & $5 \%$ \\
\hline In & 71876 & $100 \%$ & 58068260 & $100 \%$ \\
\hline
\end{tabular}

Fonte: ANEEL, 1998.

Nota: Faturamento tendo como base o mês de abril de 1988.

Com base nesses dados, estima-se que o faturamento anual das concessionárias somente com o fornecimento de energia elétrica para iluminação pública, atinja cifras da ordem de 750 milhōes de reais, o que representa cerca de $2,74 \%$ do faturamento total com energia elétrica (ANEEL, 1999). 


\subsubsection{Polêmicas na aplicação das tarifas de iluminação pública}

\section{A remuneração dos serviços de manutenção via tarifa B4b}

Em principio, a tarifa B4b só deveria ser aplicada quando o sistema de IP pertencesse às concessionárias. Porém, existem casos em que elas não são proprietárias do sistema de iluminação pública mas prestam os serviços de manutenção mediante a cobrança da tarifa B4b. Um exemplo é a SAELPA, no caso da cidade de João Pessoa, capital da Paraíba (PMJP, 1997).

A rigor, nos casos em que as instalações de iluminação pública pertencem ao município, os serviços de manutenção deveriam ser contratados através de licitação pública. No entanto, via modalidade tarifária, é possivel conceder os serviços de manutenção do sistema de IP à concessionária de energia elétrica sem a realização do processo licitatório, numa violação à Lei Federal 8.666/93 - lei das licitações.

Outro fato é que algumas concessionárias alegam que o valor da tarifa B4b não cobre os custos de manutenção com o sistema de IP. Entretanto, não há registro de que esse motivo tenha causado desistência da prestação desse serviço. Além do mais, considerando que as tarifas são propostas pelas próprias concessionárias ao poder concedente, não parece razoável admitir-se que elas deixem de apropriar adequadamente todos os custos envolvidos.

\section{A tarifa B4c: níveis de iluminância $X$ eficiência energética}

Para inibir o desperdicio de energia elétrica pelo excesso de potência instalada e iluminação desnecessária, a Portaria DNAEE 158/89 vinculou o valor da tarifa B4C aos níveis de iluminância produzidos pelo sistema de iluminação pública, com base nos valores de referência da NBR 5101. Desse modo, criou-se a 
possibilidade para cobrança de uma tarifa mais elevada até mesmo com a instalação de lâmpadas e reatores eficientes de menores potências, mas que produzam niveis de iluminância mais elevados.

Entretanto esse critério se tornou ineficaz e contraditório, pois uma das principais características dos equipamentos eficientes, no caso das lâmpadas e reatores/ignitores associados, é a produção de maiores niveis de iluminância com potência menor do que a tecnologia convencional equivalente. Além disso, a NBR 5101, conforme apresentado no item 2.4 do capítulo 2, não estabelece limites ou níveis máximos de iluminância, mas apenas os requisitos mínimos.

Outra polêmica é que pode ser aplicada uma tarifa mais cara simplesmente pelo fato do material empregado pelo município ser diferente do padrão definido pela concessionária. No entanto, se a própria Portaria 158 estabelece que esse sistema deve ser sempre de propriedade da prefeitura municipal, cabendo-lhe inclusive os custos de manutenção, a cobrança da tarifa B4C, por esse motivo, parece equivocada.

\subsubsection{Os níveis de preços das tarifas de iluminação Pública}

A tabela 3.2 apresenta, para cada classe de consumo, os valores das tarifas médias de energia elétrica praticadas em 1999, por região geográfica e a média Brasil. Observa-se que a média Brasil das tarifas de iluminaçāo pública, R\$ $75,49 / \mathrm{MWh}$, é a terceira menor entre as oito classes de consumo. 
TABELA 3.2 Tarifa média por classe, regional e Brasil (R\$/MWh).

\begin{tabular}{|c|c|c|c|c|c|c|}
\hline \multirow{2}{*}{ Classe de consumo } & \multicolumn{5}{|c|}{ RSAKOEETHFA } & \multirow{2}{*}{ BR $351 L$} \\
\hline & Torte & Moweste & Stdeste & SUI & $0.0 \%$ & \\
\hline acids & 141,44 & 133,53 & 139,47 & 143,12 & 138,66 & 19 \\
\hline & 6 & 50,54 & 66,30 & 72,50 & 8 & \\
\hline & 135,83 & 114,85 & 122,44 & 119,53 & 124,05 & \\
\hline & 94 & 71,15 & 80,88 & 69,69 & 78,60 & \\
\hline & 132,79 & 115,51 & 118,03 & 120,26 & 122,75 & 119,50 \\
\hline & 79,14 & 76,00 & 77,08 & 71,04 & 72,57 & 49 \\
\hline $\mathrm{Se}$ & 82,88 & 69,82 & 68,98 & 76,49 & 68,66 & 70,57 \\
\hline Consu & 134,45 & 120,82 & 65,15 & 80,90 & 130,10 & 85,83 \\
\hline 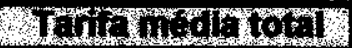 & 805 & 6507 & 97,70 & 907 & TII6 & 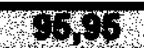 \\
\hline
\end{tabular}

Fonte: ANEEL (1999).

As tarifas médias de iluminação pública praticadas nas cinco regiōes do pais, de 1997 a 1999, são mostradas na tabela 3.3. Observa-se que a regiāo Norte possui a maior tarifa média do Brasil, o que pode ser explicado em razão da existência de diversos sistemas de geração à óleo, que têm custos operacionais maiores que os dos sistemas hidrelétricos, predominantes nas outras regiões.

TABELA 3.3 Tarifa média de IP, regional e Brasil (R\$/MWh).

\begin{tabular}{|c|c|c|c|c|c|c|}
\hline \multirow{2}{*}{ r. } & \multicolumn{5}{|c|}{ 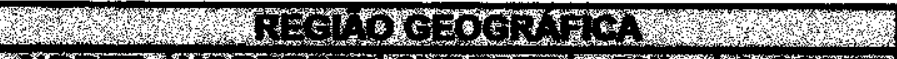 } & \multirow{2}{*}{ ENAs } \\
\hline & TORE & WOAS $=51 \mathrm{~L}$ & SEDIESTL & 1.515 & COBSTE & \\
\hline 1997 & 72,94 & 67,98 & 64,69 & 63,60 & 63,16 & 65,31 \\
\hline 1998 & 75,00 & 71,09 & 68,57 & 65,48 & 65,64 & 68,53 \\
\hline 1999 & 79,14 & 76,00 & 77,08 & 71,04 & 72,57 & 75,49 \\
\hline
\end{tabular}

Fonte: ANEEL, 1999.

O gráfico da figura 3.2 mostra as taxas de crescimento das tarifas médias de IP por regiāo, e a média Brasil referente aos períodos 1997 / 1998 e 1998 / 1999, que foi de $7,5 \%$. Verifica-se que em 1999 registrou-se significativas elevaçōes nas tarifas médias das regiōes Sudeste e Centro-Oeste, respectivamente, $10,6 \%$ e $10,2 \%$. 


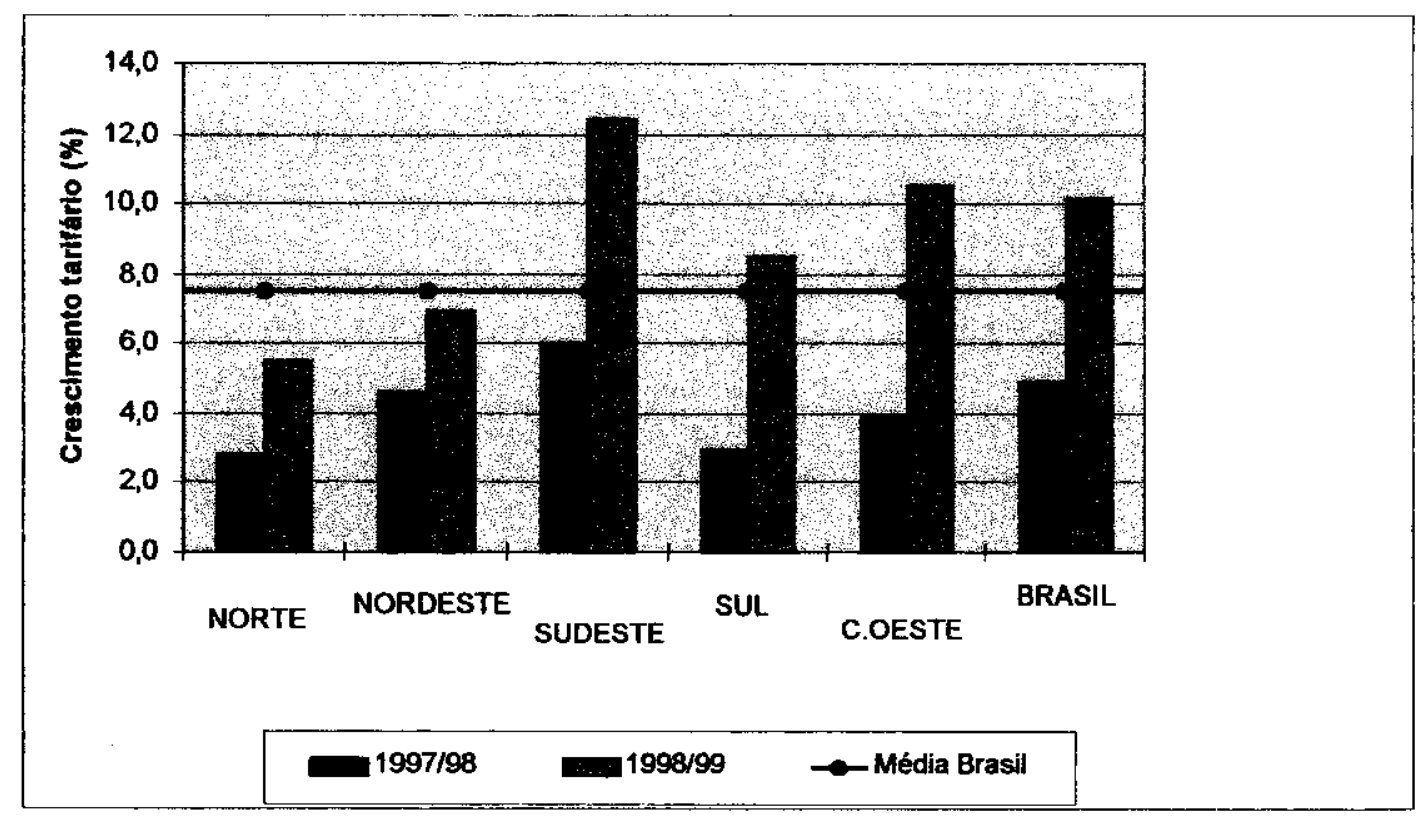

Figura 3.2 Taxas de crescimento das tarifas médias de IP por região. Fonte: IBAM/PROCEL (1997).

\subsection{Iluminação pública e o conceito econômico de bens sociais}

\subsubsection{Falhas ou imperfeições de mercado associadas aos serviços de IP}

A teoria econômica define as características de alguns bens elou serviços, cuja oferta não se constitui em atividades lucrativas para a iniciativa privada por apresentarem falhas ou imperfeições de mercado. RIANI (1994) identifica quatro falhas de mercado para o atendimento de alguns serviços: 1) indivisibilidade do produto; 2) externalidades; 3) custo de produção decrescente e mercados imperfeitos, e 4) riscos e incertezas na oferta de bens.

De acordo com os objetivos desta dissertação, serão analisados os bens ou serviços que apresentam a característica de indivisibilidade. Tais bens, classificados como bens públicos puros, não podem ser limitados no seu consumo e a sua oferta não está diretamente vinculada à sua demanda efetiva. 
Para RIANI (1994) um bem é dito indivisivel quando não é possivel estabelecer seu preço através dos mecanismos de mercado. Particularmente, tais bens apresentam as características de não-exclusividade e não-rivalidade. Um bem é dito não-exclusivo quando é impossível, ou difícil, excluir pessoas do seu consumo. Nesse caso, não se aplicando o direito de propriedade, torna-se dificil a cobrança individual $\mathrm{e}$, portanto, a sua exploração pela iniciativa privada se apresenta inviável.

Ainda segundo RIANI (1994), a não-rivalidade está associada ao fato de o consumo de determinados bens por um cidadão, não excluir a possibilidade ou diminuir a satisfação de também ser consumido por outros. Ou seja, todos desfrutam do bem, pagando ou não para isso, dificultando a avaliação da preferência de cada indivíduo na sua oferta. A figura 3.3 apresenta um diagrama proposto por Riani para ilustrar os princípios da rivalidade e da exclusão, aplicados aos bens públicos puros, ou bens sociais, e aos bens privados.

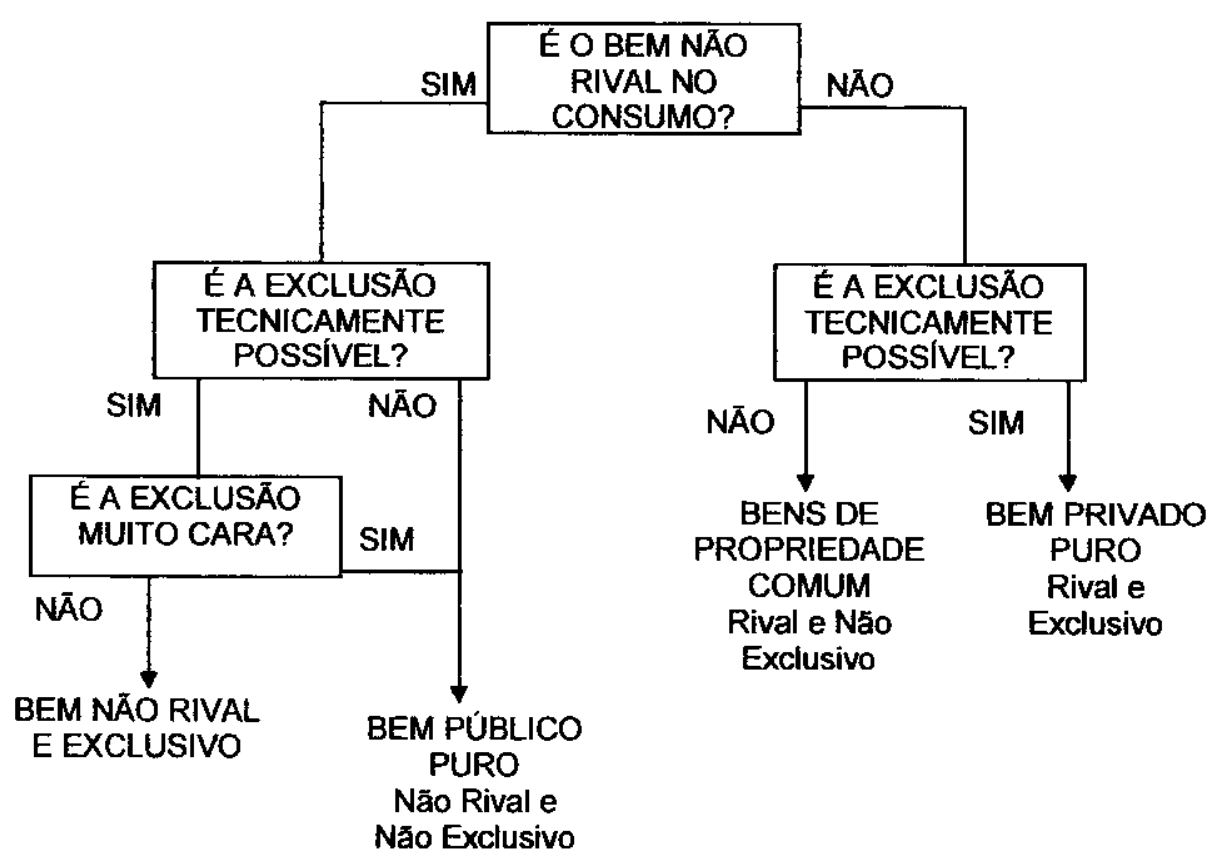

Figura 3.3 Princípios da rivalidade e da exclusão aplicados aos bens públicos e privados.

Fonte: RIANI, (1994, p.53). 
PINDYK ; RUBINFELD (1994, p. 872) concordam que "os bens públicos que são ao mesmo tempo não rivais e não exclusivos, oferecem benefícios às pessoas a um custo marginal zero, e ninguém poderia ser excluído da possibilidade de desfrutá-los". Para eles, dificuldades de se estabelecer cobrança para os bens não exclusivos, possibilita a sua utilização sem a necessidade de pagamento direto.

Surge dai uma característica particular dos serviços ou bens públicos indivisiveis: a inviabilidade econômica de sua exploração por parte da iniciativa privada. À luz da teoria apresentada, tais serviços devem ser prestados diretamente pelo governo ou suas instituições. Portanto, se a iluminação pública apresenta características de não-exclusividade e não-rivalidade no seu consumo, tais falhas ou imperfeições de mercado se enquadram no conceito econômico de serviços e bens sociais.

\subsubsection{Gestão dos sistemas de IP: um mercado competitivo}

A exploração dos serviços de iluminação pública por meio da cobrança direta aos usuários parece ser impraticável, com base na teoria apresentada no item 3.4.1. Por outro lado, quando contratados pelos municipios às firmas de engenharia ou ESCO's, é uma atividade lucrativa para essas empresas. Geralmente, nas grandes cidades, divide-se a zona urbana do município e contrata-se várias empresas para atuar em áreas diferentes. Essa prática está sendo adotada nas cidades de São Paulo/SP e Salvado/BA, só para citar dois exemplos.

No Brasil, a partir de 1997 começou a ser difundido o conceito de gestão completa da iluminação pública e o município de São Bernardo do Campo, no estado de São Paulo, parece ter sido o primeiro município brasileiro a implantar essa filosofia, em 1999. Adotada em larga escala sobretudo nos países da Europa, a gestão completa compreende o gerenciamento de todo o sistema de iluminação pública do município, incluindo acompanhamento e controle das contas de energia 
elétrica, implantação, renovação e modernização das instalaçōes de IP, operação e manutenção, e cadastramento informatizado do sistema (TESCONI, 1997).

Nesse tipo de empreendimento, a empresa contratada assume o controle do sistema de IP durante um período determinado e o município paga os serviços através de um "contrato de perfomance". Ou seja, a empresa reduz os custos de operação do sistema (energia + manutenção) e se apropria de parte dos ganhos de produtividade. A vantagem para o municipio é poder melhorar a qualidade do serviço com a redução dos custos.

O APÊNDICE C apresenta um roteiro com critérios e recomendaçōes para gestão eficiente de sistemas de iluminação pública.

\subsection{A taxa de iluminação pública - TIP}

Vários municípios brasileiros instituem a Taxa de lluminação Pública - TIP, para cobertura das despesas operacionais com o serviço de iluminação pública. A TIP é um tributo estabelecido por lei municipal aprovada pela Câmara de Vereadores, e os contribuintes são, geralmente, os consumidores de energia elétrica e os proprietários de terrenos urbanos.

A figura 3.4 apresenta uma amostra, por região geográfica do pais, dos municipios que cobram a TIP. 


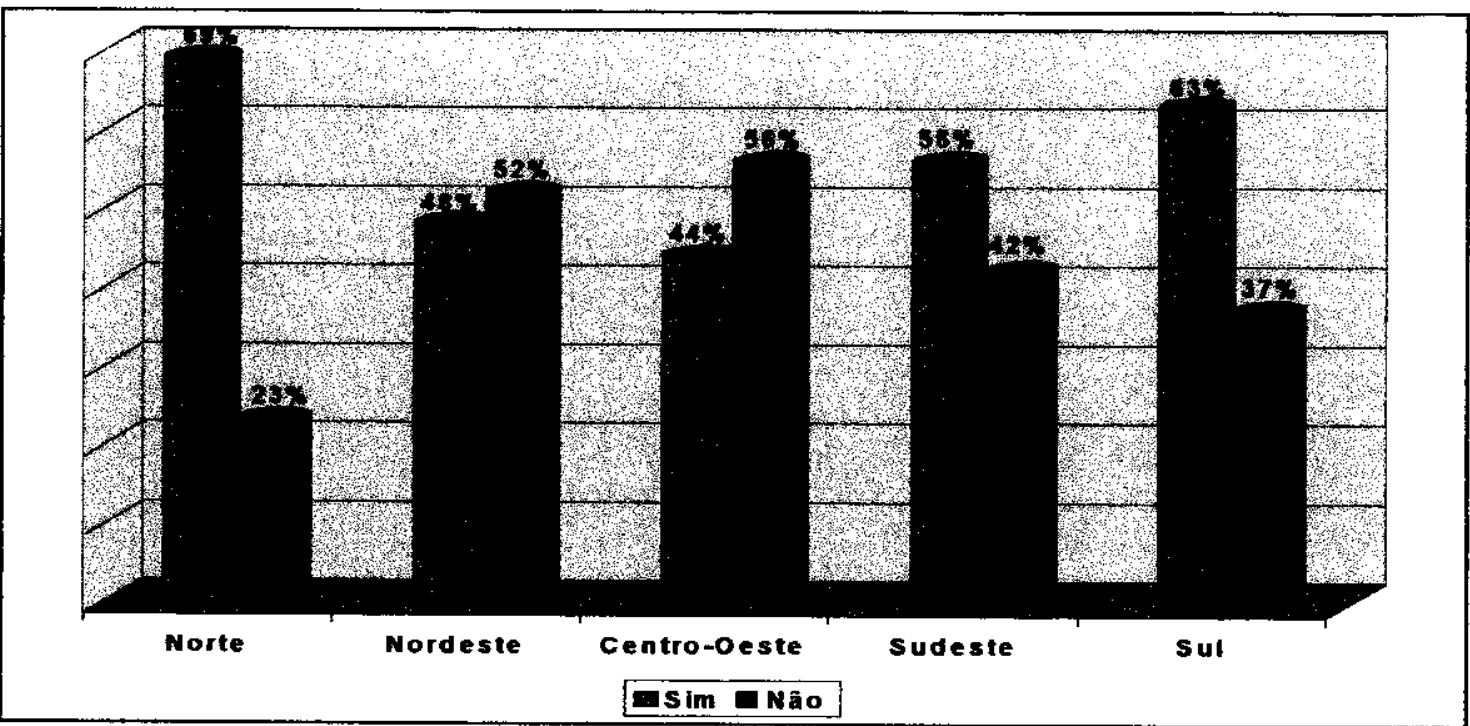

Figura 3.4 Cobrança da TIP nas regiōes brasileiras.

Fonte: IBAM/PROCEL (1997).

Além de ser uma fonte especifica de receita para o município, a TIP também é de significativo interesse para as concessionárias, pois representa uma garantia de pagamento do consumo de energia elétrica da iluminação pública, possibilitando a redução do nivel de inadimplência. Um panorama sobre as principais formas de cobrança da TIP pelos municípios é mostrado na figura 3.5.

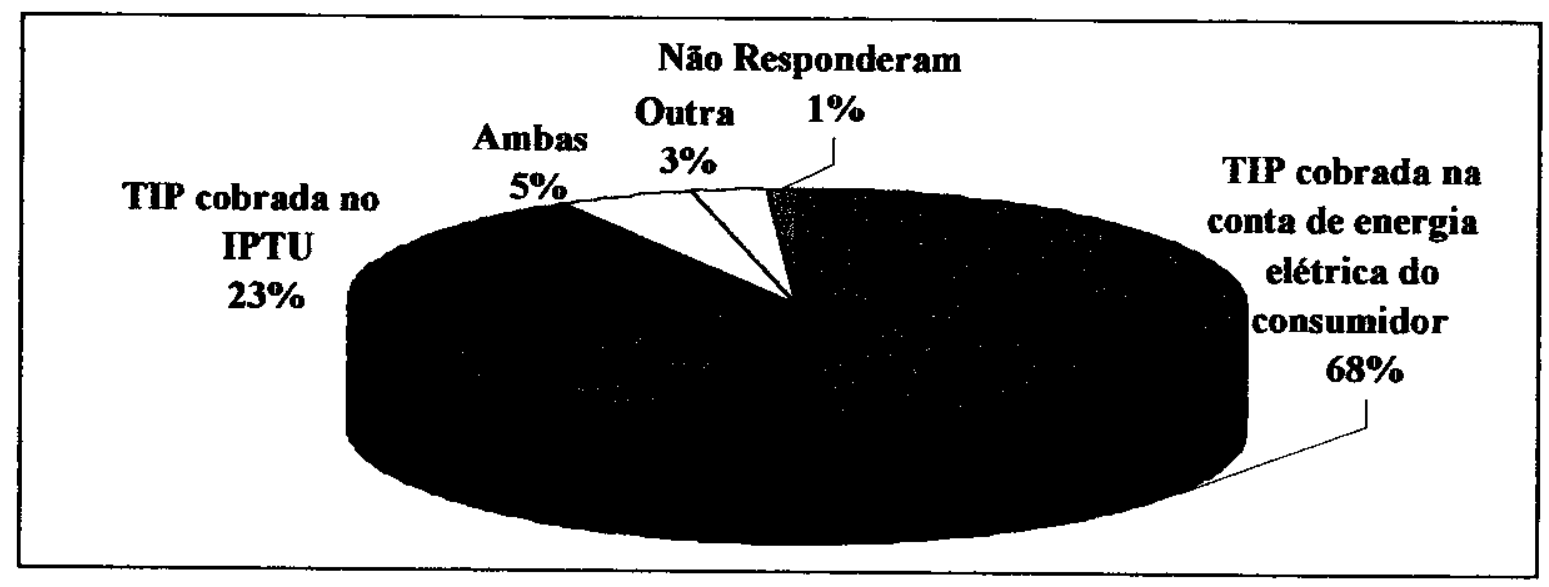

Figura 3.5 Forma de cobrança da TIP pelos municípios.

Fonte: IBAM/PROCEL (1997). 


\section{Os princípios tributários para instituicão de taxas}

O conceito de taxa e os princípios para sua cobrança são definidos na doutrina jurídica do direito tributário. Para ATALIBA (1995) taxa é o tributo cuja hipótese de incidência consiste numa atuação estatal direta e imediatamente referida ao contribuinte. $O$ atributo material da hipótese de incidência é a base de cálculo, base tributável, ou base imponivel, que se constitui no fundamento legal para a mensuração financeira do serviço prestado.

O critério de repartição do custos do serviço pelos contribuintes é estabelecido pela alíquota, que fixa e define a quota ou fração a ser atribuída a cada um deles. Portanto, o resultado da aplicação da alíquota sobre a base de cálculo é o que resulta no efetivo valor financeiro da taxa que deve ser paga pelos contribuintes (ATALIBA, 1995).

A Constituição Federal, no capitulo que trata do Sistema Tributário Nacional, artigo 145 , só admite a instituição de taxas nos casos de serviços específicos e divisíveis:

"Art. 145. A união, os Estados, o Distrito Federal e os Municipios poderão instituir os seguintes tributos:

I- impostos;

II- taxas, em razão do exercício do poder de polícia ou pela utilização, efetiva ou potencial, de serviços públicos especificos e divisiveis, prestados ao contribuinte ou postos a sua disposição;

III- contribuição de melhoria, decorrente de obras públicas.

$\S 1^{\circ}$ Sempre que possivel, os impostos terão caráter pessoal e serão graduados segundo a capacidade econômica do contribuinte, facultado à administração tributária, especialmente para conferir efetividade a esses objetivos, identificar, respeitados os direitos individuais e nos termos da lei, o patrimônio, os rendimentos $e$ as atividades econômicas do contribuinte.

$\S 2^{\circ}$ As taxas não poderão ter base de cálculo própria dos impostos". (Grifos nossos). 


\subsubsection{Contestações sobre a legalidade da cobrança da TIP}

\section{O serviço de iluminacão pública cobrado por meio de taxa}

Embora vários municipios ainda mantenham a cobrança da TIP, os Tribunais de Justiça de todo o país têm julgado a sua inconstitucionalidade e/ou ilegalidade (ANEEL, 1998). As sentenças ou acórdãos apoiam-se nos argumentos jurídicos de que a iluminação pública não satisfaz os requisitos constitucionais para cobrança de taxa, ou seja, as características de serviço especifico e divisivel.

MEIRELLES (1988) considera a iluminação pública não pode ser mensurável, nem utilizada individualmente. Para ele, somente a conjugação dos requisitos da especificidade e da divisibilidade pode justificar a cobrança de taxa. Esse também é o entendimento de Ataliba: "fica claro que o requisito constitucional é que seja possivel destacar-se unidades de utilização (o que supõe que o serviço seja divisível, como estabelece a Constituiçāo, como condição de remunerabilidade por taxa), para fruição individual pelos administrados. Cada utente deverá pagar na medida da utilização" (ATALIBA 1995, p.134).

Base de cálculo vinculada ao consumo de energia elétrica ou semelhante à de impostos

A cobrança dos serviços de iluminação pública aos usuários pode conter, simultaneamente, dupla ilegalidade nos casos em que além de ser realizada por meio de taxa - o que já seria uma condição suficiente de inconstitucionalidade - a base de cálculo seja vinculada ao consumo de energia elétrica ou seja igual a de outros impostos.

Com a promulgação da Constituição Federal em 1988, foi extinto o Imposto Único sobre Energia Elétrica - IUEE e instituído o Imposto sobre a Circulação de 
Mercadoria e Serviços - ICMS, que também passou a incidir sobre energia elétrica. A partir de então, conforme o parágrafo $3^{\circ}$ do artigo 155 da Constituição, à exceção do ICMS e dos impostos de importação e exportação de que tratam os incisos I e II do artigo 153, não deve existir quaisquer outros tributos sobre as operações relativas a energia elétrica:

\begin{abstract}
"Art. 145, § $3^{\circ}$ - À exceção dos impostos de que tratam o inciso II do caput deste artigo e o art. 153, I e II, nenhum outro tributo poderá incidir sobre operações relativas a energia elétrica, senviços de telecomunicações, derivados de petróleo, combustiveis e minerais do País".
\end{abstract}

Se a base de cálculo for semelhante a de outros impostos, infringe-se diretamente o $\S 2^{\circ}$ do artigo 145 da Constituição Federal. Para citar um exemplo, o Supremo Tribunal Federal - STF, já publicou acórdão julgando inconstitucional a TIP instituída com a base de cálculo idêntica a do IPTU. O Código Tributário Nacional dispōe sobre a cobrança do IPTU nos seus artigos 32 e 33 da seguinte forma:

"Art. 32 o imposto de competência dos Municipios, sobre a
propriedade predial e temitorial urbana tem como fato gerador a
propriedade, o domínio útil ou a posse do bem imóvel por natureza
ou acessão física, como definido na lei civil, localizado na zona
urbana do Município". " $\$ 1^{\circ}$ Para os efeitos deste imposto, entende-se como zona urbana a definida em lei municipal, observado o requisito mínimo da existência de melhoramentos indicados em pelo menos dois dos incisos seguintes, construídos ou mantidos pelo Poder Público:

I- meio-fio ou calçamento, com canalização de águas pluviais;

II - abastecimento d'água;

III - sistema de esgotos sanitários;

IV - rede de iluminação pública, com ou sem posteamento para distribuição domiciliar; (Grifos nossos).

$V$ - escola primária ou posto de saúde a uma distância máxima de 3 (três) quilômetros do imóvel considerado".

"Art. 33 A base de cálculo do imposto é o valor venal do imóvel". 
No caso julgado pelo STF, a base de cálculo da TIP era o comprimento da testada ou a área dos imóveis; a do IPTU, o valor venal do imóvel, obtido pelo valor padrão da área (em metro quadrado) construída. O STF considerou que as unidades de referência para quantificação da TIP e do IPTU, o metro, tinham a mesma base.

\section{Sentenca contra a TIP em João Pessoa - PB}

Como exemplo de julgamento da inconstitucionalidade da cobrança da TIP, transcreve-se os termos do acórdão do Tribunal de Justiça do Estado da Paraíba, na Ação Civil Pública interposta pelo Ministério Público contra a cobrança da TIP pela Prefeitura Municipal de João Pessoa:

"A taxa de iluminação pública não se configura em serviço especifico e divisivel, que o cidadão possa usufruir quando dele precisar ou querer usufruir, e ai recolher a taxa instituida. De fato, o serviço de iluminação pública é prestado à toda coletividade de uma só vez, e não singularmente a cada munícipe".

"Da mesma maneira como é fornecida, ou seja, indistintamente, insuscetivel de utilização separadamente, por cada um dos que precisem ou queiram utilizar o serviço, e da forma que ela é cobrada, a todos os habitantes impositivamente e na mesma valoração, não coaduna com legislação enfocada e reguladora das obrigações que podem ser submetidos os contribuintes, tornando-a completamente ilegal". ( ACÓRDÃO exarado em 24 de abril de 1977 pela Primeira Câmara Cível do TJPB).

\subsubsection{Os exemplos da TIP em Maceió, Salvador e Rio de Janeiro}

\section{A TIP em Maceió}

Em Maceió, capital do estado de Alagoas, a TIP era cobrada mediante um percentual sobre o consumo de energia elétrica dos consumidores. Esse 
procedimento foi questionado na justiça e a Prefeitura Municipal conseguiu manter a cobrança da TIP introduzindo modificações na sua base de cálculo ${ }^{23}$.

Pela nova lei, os contribuintes da TIP são os proprietários ou possuidores de imóveis, edificados ou não, ligados ou não à rede de concessionária de energia elétrica, situados nos logradouros públicos beneficiados pela iluminação pública.

Os imóveis ou seus proprietários são considerados beneficiados desde que exista iluminação pública em: a) pelo menos um dos lados das vias públicas; b) em todo o perímetro das praças públicas, independentemente da forma de distribuição dos postes e luminárias; c) parcialmente, dentro de círculos, cujos centros estejam em um raio de 30 (trinta) metros do poste dotado de luminária, nas vias públicas não iluminadas em toda a sua extensão, assim consideradas aquelas em que a distância entre luminárias sucessivas for superior a 100 (cem) metros.

A TIP é calculada em função do serviço de iluminação das características de destinação dos imóveis, e os valores pagos pelos contribuintes são estipulados em Unidade Fiscal de Referência - UFIR, da seguinte forma: a) imóveis residenciais: 4 (quatro) UFIR; b) imóveis comerciais: 6 (seis) UFIR; e c) imóveis não edificados: 2 (duas) UFIR.

No caso de hotéis, hospitais, pensões, colégios, bancos, fábricas, oficinas, bares, restaurantes, cafés, lanchonetes, sorveterias, clubes esportivos, teatros, cinemas, postos de lavagem e lubrificação, supermercados e outros estabelecimentos semelhantes, o valor cobrado é de 12 (doze) UFIR. 


\section{A TIP em Salvador}

A Taxa de lluminação Pública em Salvador, capital do estado da Bahia, tem como fator gerador a utilização, efetiva ou potencial, dos serviços públicos de iluminação pública nas vias e logradouros públicos, prestados ao contribuinte ou postos à sua disposição. Os contribuintes da TIP são os proprietários, os titulares do domínio útil ou os possuidores, a qualquer título, de unidades imobiliárias edificadas, lindeiras às vias ou logradouros públicos servidos por iluminação pública.

A base de cálculo da TIP é o custo dos serviços de iluminação das vias e logradouros públicos a ser rateado entre os contribuintes em função do número de unidades imobiliárias edificadas, lindeiras às vias ou logradouros públicos servidos por iluminação pública.

O custo dos serviços compreende: a) despesas mensais com energia consumida pelos serviços de iluminação pública; b) despesas mensais com administração, operação e manutenção dos serviços de iluminação pública; c) quotas mensais de depreciação de bens e instalações do sistema de iluminação pública e, d) quotas mensais de investimentos destinados a suprir encargos financeiros para a expansão, melhoria ou modernização do sistema de iluminação pública.

A cobrança da TIP é feita nas contas de energia elétrica da concessionária e tem dois valores: um para os consumidores residenciais e outro para os nãoresidenciais, que não poderão exceder a $10 \%$ (dez por cento) do valor do consumo de energia elétrica do contribuinte no respectivo mês. Os contribuintes classificados como de baixa renda junto à ANEEL são isentos do pagamento. 


\section{A TIP no Rio de Janeiro}

Na cidade do Rio de Janeiro, capital do estado do Rio de Janeiro, a TIP tem como fato gerador a utilização, efetiva ou potencial, dos serviços de iluminação de vias e logradouros públicos situados no município. Os contribuintes são os proprietários de imóveis, edificados ou não, independentemente da destinação de uso e/ou posseiros e ocupantes dos imóveis beneficiados com o serviço. ${ }^{24}$

A base de cálculo para cobrança da TIP é o custo do serviço de iluminação pública, calculado de acordo com a localização e destinaçāo dos imóveis distribuídos em cinco regiōes fiscais definidas pelo município para efeito de tributação. A alíquota é um coeficiente aplicado sobre o valor da UNIF.

\subsubsection{A cobrança dos serviços de IP no Equador e na Argentina}

Nas principais cidades do Equador (Quito, Guayaquil e Cuenca) o cliente paga, em média, $30 \%$ a mais sobre o valor do consumo de eletricidade devido às taxas incidentes para cobertura dos serviços de eletrificação rural, bombeiros, seguro contra incêndio, coleta de lixo, custos de comercialização de energia elétrica e o consumo de energia elétrica da iluminação pública (VIZHÑAY, 1996).

Na cidade Cipolletti na Argentina, as despesas com o consumo de energia elétrica, operação e manutenção do sistema de iluminação pública são rateadas entre os consumidores da concessionária local. A cobrança é feita na conta de energia elétrica e diretamente pelo Município aos proprietários de terrenos. No caso da cobrança pela concessionária, o não pagamento pelo consumo de

\footnotetext{
24 A lei que regulamenta a TIP no Rio de Janeiro é o Decreto Municipal № 14.327, de 01 de novembro de 1995, que também regulamenta o IPTU a Taxa de Coleta de Lixo e Limpeza Urbana.
} 
energia elétrica da iluminação pública acarreta também a suspensão do fornecimento de energia dos consumidores (PEDRANTI, 1997).

\subsubsection{Alternativas legais para o custeio dos serviços de IP}

Encontram-se tramitando no Congresso Nacional quatro projetos relacionados com a TIP: um de emenda à Constituição Federal e três de criação de lei complementar.

O projeto de emenda à Constituição propõe nova redação ao parágrafo terceiro do Artigo 145 para criar uma exceção para cobrança de taxas pela utilização dos serviços de coleta de lixo e de iluminação pública. A base de cálculo seria fixada de modo equivalente ao custo total da prestação dos serviços dividido pelos usuários.

Dos três projetos de lei complementar, um deles proíbe explicitamente a cobrança da TIP, ratificando as decisões dos Tribunais de Justiça de todo o Brasil, inclusive do Supremo Tribunal Federal, que considera a iluminação pública um serviço público genérico e indivisível, e não pode ser cobrado por meio de taxa. O segundo autoriza a cobrança da TIP, desde que a base de cálculo não tenha como fato gerador o consumo domiciliar de energia elétrica, a área ou a testada do imóvel, ou que se aplique por serviço de uso comum e indivisível.

O terceiro projeto, ao contrário do segundo, propõe exatamente que a TIP tenha a testada ou a área do imóvel como base de cálculo, não se confundindo com a base de cálculo do imposto predial e territorial urbano. Considera ainda a iluminação pública, em bem de uso comum, um serviço público específico e divisivel. Os textos dos projetos aqui discutidos são apresentados na integra no APÊNDICE D. 
Existe ainda uma proposta da Confederação Nacional dos Municipios e do Conselho Brasileiro de Integração Municipal, para alteração da Lei $n^{\circ} 9.427$ de 26 de dezembro de 1996, que instituiu a ANEEL e disciplina o regime das concessões de serviços públicos de energia elétrica (ANEEL, 1999). Por essa proposta, a referida lei passaria a vigorar com a introdução de dois parágrafos:

"§ $3^{\circ}$ - As tarifas de formecimento aplicáveis às classes consumidoras das concessionárias e permisionárias do serviço público de distribuição, a serem homologadas pela ANEEL, cobrirão o consumo de energia elétrica destinada à iluminação pública, segundo os critérios e condições definidos pela Agência, excluídos os custos relacionados à operação, manutenção e expansão da rede de iluminação pública, de responsabilidade do Município".

"§ $4^{\circ}$ - "O disposto no parágrafo anterior não se aplica aos casos em que o poder público municipal tenha assumido, ou venha a assumir, com dotações próprias de seu orçamento, o pagamento das contas de energia elétrica referentes ao consumo de iluminação pública".

A principio se constata que esta proposição não contempla a cobertura das despesas com manutenção, mas apenas os valores referentes ao consumo de energia elétrica da iluminação pública, que seriam distribuídos entre as demais classes consumidoras. Por outro lado, o parágrafo $4^{\circ}$, ao tornar facultativa a aplicação desse critério, enseja diferenças nos níveis das tarifas para consumidores de uma mesma classe na mesma área de concessão, o que fere o princípio da igualdade.

\subsection{Conclusões}

A análise histórica da regulamentação do setor elétrico brasileiro revela a ausência de uma política tarifária estável e estruturada em bases teóricas e conceituais solidamente definidas. Essa situação que parece perdurar até hoje, é evidenciada 
pela legislação atual ao desvincular as tarifas de qualquer critério anterior, nos casos das empresas a serem privatizadas e nas novas concessões.

A teoria dos custos marginais, e não o mecanismo do custo do serviço, pode oferecer os fundamentos para promover a alocação eficiente dos recursos energéticos e econômicos. Isso é possivel através do estabelecimento de uma estrutura tarifária que sinalize a cada grupo de consumidores os custos de capacidade e energia por eles incorridos nos diversos segmentos do sistema elétrico e em cada posto tarifário. Embora o governo federal tenha criado as condiçöes legais para a implantação dessa metodologia, verificou-se que na prática sua aplicação foi restrita e não vem sendo mais adotada.

O estabelecimento das tarifas B4b e B4c teve como objetivos contemplar, respectivamente, os casos de instalações de iluminação pública pertencentes às concessionárias e incentivar a eficiência energética nesse setor. Entretanto, passaram a existir polêmicas jurídicas e de interpretações quanto às tarifas B4b e B4c. Quanto aos atuais niveis praticados, não há elementos suficientes para afirmar com precisão se eles estão razoáveis ou não, em virtude da ausência de uma estrutura que permita definir os custos efetivamente incorridos por essa classe de consumo na formação dos custos globais de cada concessionária.

O conceito de serviço indivisivel tem definições não conflitantes nas teorias econômica e jurídica. No caso da iluminação pública, percebe-se que não é possivel a cobrança dos serviços por meio de taxa, pois trata-se de um serviço prestado à população de uma forma geral. Em outras palavras, a iluminação pública de uma cidade beneficia todas as pessoas que trafegam nas vias e logradouros públicos, independentemente da vontade ou não de utilização desse serviço, o que dificulta ou impossibilita a mensuraçāo individual por cada usuário.

Embora algumas cidades ainda mantenham a cobrança da TIP, a possibilidade de contestação jurídica é uma iminente ameaça. Portanto, viabilizar legalmente uma 
fonte específica de recursos para o custeio dos serviços de iluminação pública tem sido uma das reivindicações históricas dos municípios. Pelo exposto neste capitulo, parece dificil encontrar soluções que se enquadrem totalmente no arcabouço legal e doutrinário em vigor, o que nos leva a concluir que essa questão deverá ser resolvida mais no plano político do que no jurídico. Caso contrário, aos municípios restará a alternativa de custear os serviços de iluminação pública com recursos da receita global de seus impostos. 


\section{OPORTUNIDADES E BARREIRAS PARA EFICIÊNCIA ENERGÉTICA NA ILUMINAÇÃO PÚBLICA}

\subsection{Bases para eficiência energética: breve revisão histórica e conceitual}

\section{Os choques dos precos do petróleo e a eficiência energética}

Os "choques" dos preços do petróleo ocorridos na década de 70 , tiveram influência decisiva para o desenvolvimento mundial da eficiência energética. $A$ partir de então, forçados por pressões econômicas e interrupçōes no suprimento de combustivel, vários paises começaram a diversificar sua matriz energética na busca de alternativas ao uso do petróleo (BANCO MUNDIAL, 1993).

GELLINGS (1996) destaca que durante esse periodo as dificuldades do setor energético também foram agravadas pela escassez de recursos financeiros para investimentos na oferta de energia, pelos aumentos das taxas de juros internacionais e pela inflação. Esses fatos, aliados à maior percepção dos problemas ambientais causados pela queima dos combustiveis fósseis, causaram significativo impacto nas empresas de energia elétrica e são apontados como os principais fatores para a tomada de consciência rumo à uma nova abordagem no planejamento energético mundial (FLAVIN ; LENSSEN, 1994).

Diante das incertezas do mercado energético decorrentes neste cenário, uma das estratégias adotadas pelas empresas de energia elétrica para manter o equilibrio entre a oferta e as crescentes demandas, foi a de estudar o comportamento da carga para produzir mudanças na sua magnitude e nos horários de consumo, o que veio a se denominar de GLD - Gerenciamento pelo Lado da Demanda (GELLINGS, 1996). 
FIGUEIREDO (1997) considera que os programas de GLD nas empresas distribuidoras de energia elétrica podem ser alternativas viáveis, quando comparados com as opçōes que contemplam apenas a expansão da oferta para atender o mercado.

GARDNER ; ROBINSON (1993) confirmam que entre o final dos anos 70 e começo dos anos 80 verificou-se um significativo interesse na análise da demanda de energia, devido aos preços e a ruptura no suprimento do petróleo. Eles lembram que outra questão mais recente - a participação da energia para o efeito estufa - tem contribuido para o crescimento da consciência ambiental e para destacar a importância da energia para o desenvolvimento sustentável.

Em adição aos problemas econômicos e energéticos causados pela elevação dos preços do petróleo, as previsōes de crescimento populacional nos países em desenvolvimento e o possivel aumento na demanda pelos serviços energéticos, apontavam para a ocorrência de sérios problemas ao meio ambiente e maiores pressões nos recursos energéticos globais, caso fossem mantidos os padröes de consumo atingidos pelos países desenvolvidos (Comissão Mundial sobre Meio Ambiente e Desenvolvimento - CMMAD, 1991).

O consumo de energia nos países em desenvolvimento não atingiu os niveis dos países industrializados, mas tem crescido à taxas maiores do que a destes. Segundo o BANCO MUNDIAL (1993), nos últimos vinte anos o consumo de energia nos paises em desenvolvimento cresceu, em média, a uma taxa anual de $5,3 \%$, contra $0,7 \%$ nos paises da OCDE, ou seja, quase sete vezes mais. No setor de energia elétrica, numa amostra que abrangeu 51 países em desenvolvimento, verificou-se que em $90 \%$ deles a capacidade instalada e a geração per capita aumentaram duas vezes mais do que o crescimento real do PIB (BANCO MUNDIAL, 1993). 
Entretanto, se por um lado os choques dos preços do petróleo causaram uma série de problemas econômicos e sociais em quase todo o mundo, por outro, parece nāo haver dúvida de que eles proporcionaram as condiçōes decisivas para melhoria da eficiência energética, sobretudo nos paises ricos (LENSSEN, 1993).

Só para citar dois exemplos, DUTT (1993) concorda que os paises industrializados foram bem sucedidos na diminuição da demanda de petróleo através da combinação de medidas de conservação de energia e de substituição de combustivel. A CMMAD (1991) destaca que os ganhos de rendimento obtidos por alguns países industrializados nos últimos 13 anos, advieram em grande parte da elevação dos preços da energia desencadeada pelo aumento dos preços do petróleo.

\section{Estratégias energéticas para os usos finais da energia elétrica}

Ao longo dos processos de produção e de consumo de energia elétrica registramse diferentes indices de desperdício e de ineficiência que poderiam ser reduzidos. Desde a etapa de geração, passando pelas de transmissão e distribuição de eletricidade, até chegar aos equipamentos de consumo final, é possivel implementar ações de eficiência energética e de incentivo ao uso racional da energia, para minimizar as perdas e otimizar a capacidade instalada do sistema elétrico.

Para DUTT (1993), na análise da energia orientada para os usos finais, o foco principal é a busca da melhoria do rendimento dos equipamentos que proporcionam os serviços energéticos. Ou seja, o objetivo é identificar tecnologias que permitam satisfazer as necessidades energéticas ao menor custo, levando-se em consideração as medidas de eficiência energética. 
Ele considera que a premissa principal se baseia no conceito de que o serviço energético é o objeto desejado no consumo de energia, por exemplo, aquecimento, refrigeração, iluminação, etc., e, portanto, uma maior ênfase deve ser dada às opçōes de reduzir perdas de conversão em energia final. A estratégia a ser adotada é o exame detalhado de como a energia é utilizada sob os aspectos técnicos, econômicos e ambientais, permitindo a identificação das melhores opções de satisfazer as demandas energéticas futuras e as alternativas dos equipamentos energéticos mais eficientes (DUTT, 1993). ${ }^{25}$

De acordo com GELLINGS (1996), enquanto o gerenciamento da demanda altera o perfil da carga reduzindo o consumo no periodo de ponta do sistema elétrico, a eficiência energética reduz o consumo de energia por todo o tempo.

\subsection{O potencial de conservação de energia elétrica na iluminação pública}

Existem em todo o Brasil, cerca de 13 milhöes de lâmpadas instaladas nos sistemas de iluminação pública, conforme detalhado na tabela 4.1.

TABELA 4.1 Número de lâmpadas de IP instaladas no Brasil por região.

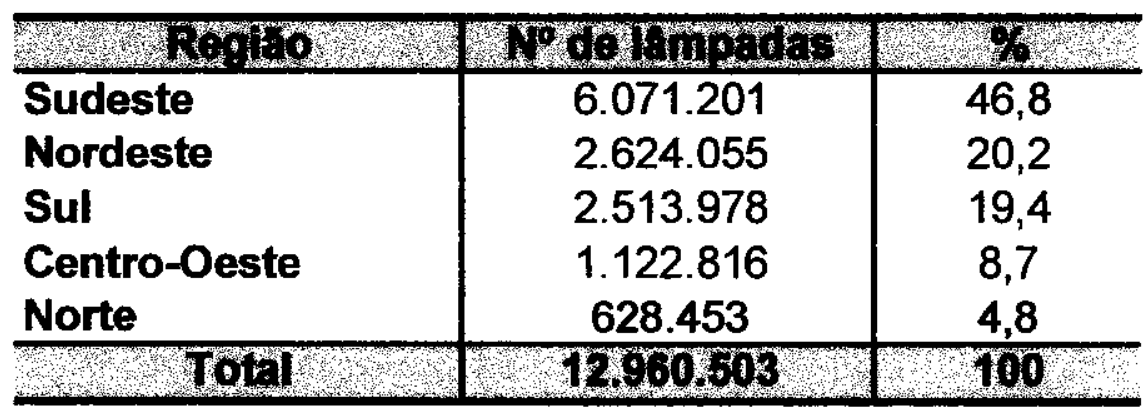

Fonte: ELETROBRÁS (1999).

25 Dutt define energia final como sendo o consumo de energia no equipamento de uso final. Ou seja, energia final = energia útil / eficiência de uso final (DUTT, 1993, p.12-13). 
O Sudeste é a região que apresenta a maior quantidade de lâmpadas, sendo responsável por quase a metade do total instalado no Brasil e, a região Norte, a menor, com apenas $4,8 \%$.

A tabela 4.2 mostra a quantidade total de lâmpadas por tecnologia, onde observase a predominância de lâmpadas do tipo vapor de mercúrio, representando cerca de $84 \%$, e a reduzida participação das lâmpadas incandescentes, com apenas $3,9 \%$ do total.

TABELA 4.2 Tipos de lâmpadas de IP instaladas no Brasil.

\begin{tabular}{|c|c|c|}
\hline Tpo de L Lmpada & Quantobas & $\%$ \\
\hline Vapor de Mercúrio & 9.262 .800 & 71,5 \\
\hline Vapor de Sódio & 2.051 .091 & 15,8 \\
\hline Mista & 983.968 & 7,6 \\
\hline Incandescente & 504.043 & 3,9 \\
\hline Outros & 152.219 & 1,2 \\
\hline Tot & 12851121 & 100 \\
\hline
\end{tabular}

A potência instalada nos sistemas de iluminação pública totaliza $2.431 \mathrm{MW}$, o que corresponde a um consumo anual de aproximadamente $10.380 \mathrm{GWh}$. As tabelas 4.3 e 4.4 apresentam a potência instalada por região geográfica e por tipo de lâmpada, respectivamente. 
TABELA 4.3 Potência instalada na IP por região.

\begin{tabular}{l|c|c}
\hline \multicolumn{1}{c|}{ Regiao } & WW & $\%$ \\
\hline Sudeste & 1.193 & 49,1 \\
Nordeste & 456 & 18,8 \\
Sul & 444 & 18,3 \\
Centro-Oeste & 234 & 9,6 \\
Norte & 104 & 4,3 \\
\hline \multicolumn{1}{c|}{ Total } & 2431 & 100 \\
\hline
\end{tabular}

Fonte: ELETROBRÁS (1999).

TABELA 4.4 Potência instalada por tipo de lâmpada.

\begin{tabular}{l|c|c}
\hline Tipo de Lampada & WW & $\%$ \\
\hline Vapor de Mercúrio & 1.621 & 67 \\
Vapor de Sódio & 517 & 21 \\
Mista & 193 & 8 \\
Incandescente & 76 & 3 \\
Outros & 24 & 1 \\
\hline \multicolumn{1}{c|}{ Total } & 2431 & 100 \\
\hline
\end{tabular}

Fonte: ELETROBRÁS (1999).

A ELETROBRÁS (1999) estima que exista um potencial técnico para substituir cerca de 10,8 milhões de lâmpadas de iluminação pública, distribuídas nas diversas regiōes do país. Isso representa uma redução de $553 \mathrm{MW}$ no horário de ponta do sistema elétrico, ou cerca de $23 \%$ da potência total instalada em iluminação pública, e um consumo evitado de energia elétrica de $2.422 \mathrm{GWh} / a n$ o.

A tabela 4.5 apresenta o potencial técnico de conservação de energia elétrica na iluminação pública, por região. 
TABELA 4.5 Potencial de conservação de energia elétrica na IP por região.

\begin{tabular}{l|c|c}
\hline \multicolumn{1}{c|}{ Reglibo } & MW & $\%$ \\
\hline Sudeste & 269,7 & 48,8 \\
Nordeste & 104,5 & 18,9 \\
Sul & 93,6 & 16,9 \\
Centro- Oeste & 64,4 & 11,7 \\
Norte & 20,5 & 3,7 \\
\hline \multicolumn{1}{c|}{ Total } & 553 & $\mathbf{1 0 0 , 0}$ \\
\hline
\end{tabular}

Fonte: ELETROBRÁS (1999).

\section{Equipamentos automáticos de reducão do consumo na IP}

A redução da potência nos sistemas de iluminação pública é proporcionada, principalmente, pela maior eficiência energética das lâmpadas VSAP e dos reatores. Existem, no entanto, possibilidades técnicas para deslocar a ponta ou reduzir a carga da iluminação pública por meio de mudanças no horário de funcionamento (controle indireto), e da redução de potência fornecida às lâmpadas durante o periodo de funcionamento (controle direto).

A maioria dos sistemas de iluminação pública entram em operação automaticamente, acionados por relés fotelétricos que exercem as funçōes de ligar e desligar as lâmpadas. Isto ocorre quando se verificam os níveis mínimos e máximos de iluminância global produzida pela luz do dia, cujos limites indicam a necessidade de claridade artificial ou não. ${ }^{26}$

Com o ajuste do tempo de operação dos relés, é possivel diminuir o número normal de horas de operação do sistema de iluminação pública para reduzir a demanda de ponta e economizar energia elétrica. Do mesmo modo, o controle

\footnotetext{
26 De acordo com a NBR 5123 da ABNT - Relé fotelétrico para iluminação pública, o relé deve ligar uma lâmpada entre os niveis de iluminância de 3 a 20 lux, e desligá-la no máximo com 80 lux.
} 
automático da potência fornecida às lâmpadas por meio de reatores convencionais ou eletrônicos eficientes, também pode reduzir a demanda, mas tem como consequeência direta a redução dos níveis de iluminância produzidos pelo sistema de iluminação pública.

Portanto, é necessário analisar criteriosamente os tipos de logradouros onde esses dispositivos poderiam ser instalados sem haver prejuizo da segurança pública pela redução dos niveis de iluminância, sobretudo nos horários de maior movimento de pedestres e de veículos nos grandes centros urbanos. Por outro lado, eles podem oferecer uma importante contribuição no combate ao desperdício de energia elétrica na iluminação pública nos horários de menor volume de tráfego e em aplicações especificas, tais como túneis, pátios de estacionamentos públicos e de supermercados, e auto-estradas, só para citar alguns exemplos.

\subsection{Oportunidades e barreiras para a eficiência energética}

As oportunidades e barreiras para a eficiência energética e a conservação de energia podem ser classificadas de diversas maneiras. No entanto elas devem ser analisadas do ponto de vista de cada ator, considerando que nem todas ocorrem simultaneamente ou têm a mesma repercussão para cada um deles. Neste item será apresentado um resumo das principais oportunidades e barreiras para o desenvolvimento da eficiência energética em geral.

\section{Oportunidades}

Os custos crescentes da produção de energia e a necessidade de prover demandas cada vez maiores nos países em desenvolvimento, tornou-se uma equação de difícil solução. De um lado, o limitado acesso aos financiamentos; de 
outro, os impactos sociais e ambientais causados pela construção e operação de novos empreendimentos energéticos.

As emissões de gases prejudiciais à saúde provenientes da queima de combustíveis fósseis e a inundação de extensas áreas para formação dos reservatórios de hidrelétricas que, em muitos casos, impõe o deslocamento de populações, são apenas alguns dos problemas decorrentes da produção de energia (BORENSTEIN ; CAMARGO, 1997).

Atualmente, buscar alternativas que conciliem o crescimento e o desenvolvimento sustentáveis com a utilização racional dos recursos finitos do planeta, é uma questão central. Em todo o mundo parece não haver dúvida de que práticas com vistas à eficiência energética são viáveis, não só do ponto de vista técnico e econômico, mas sobretudo pelos resultados ambientais positivos (USAID, 1996).

Para HOLDREN (1990) o aumento da eficiência energética é um método efetivo de reduzir impactos ambientais com vantagens econômicas. HIRST (1991) aponta sete beneficios proporcionados pelas medidas para eficiência energética nos Estados Unidos, que podem ser generalizados para vários países, inclusive o Brasil:

- economia para os consumidores;

- aumento da produtividade econômica, favorecendo a competitividade internacional;

- redução dos preços dos combustíveis, pela redução do poder de mercado de produtores estrangeiros;

- redução dos impactos ambientais, especialmente chuva ácida e aquecimento global;

- diversidade e flexibilidade para a matriz energética, e

- estímulo para o interesse público em eficiência energética. 
Torna-se evidente, porém, que conciliar o atendimento energético com a redução dos impactos sociais e ambientais, exige mudanças nos pressupostos do planejamento energético, ainda fortemente centrados na oferta de energia. Em outras palavras, "é preciso fazer opçōes, mas sabendo que a escolha de uma estratégia energética determinará inevitavelmente a escolha de uma estratégia ambiental" (CMMAD, 1991, p.186).

Para a USAID (1996) é preciso não só descobrir as oportunidades favoráveis de mercado para eficiência energética, mas envolver parceiros que tenham um forte incentivo econômico para atuar, desenvolver projetos com retornos atrativos e utilizar uma estrutura financeira adequada.

A figura 4.1 apresenta os fundamentos de mercado para investimentos em eficiência energética propostos pela USAID. Eles baseiam-se em quatro aspectos principais: 1) natureza das oportunidades de mercado; 2) condições do setor de energia do país; 3 ) definição das políticas de governo para eficiência energética e, 4) condições econômicas e comerciais do país.

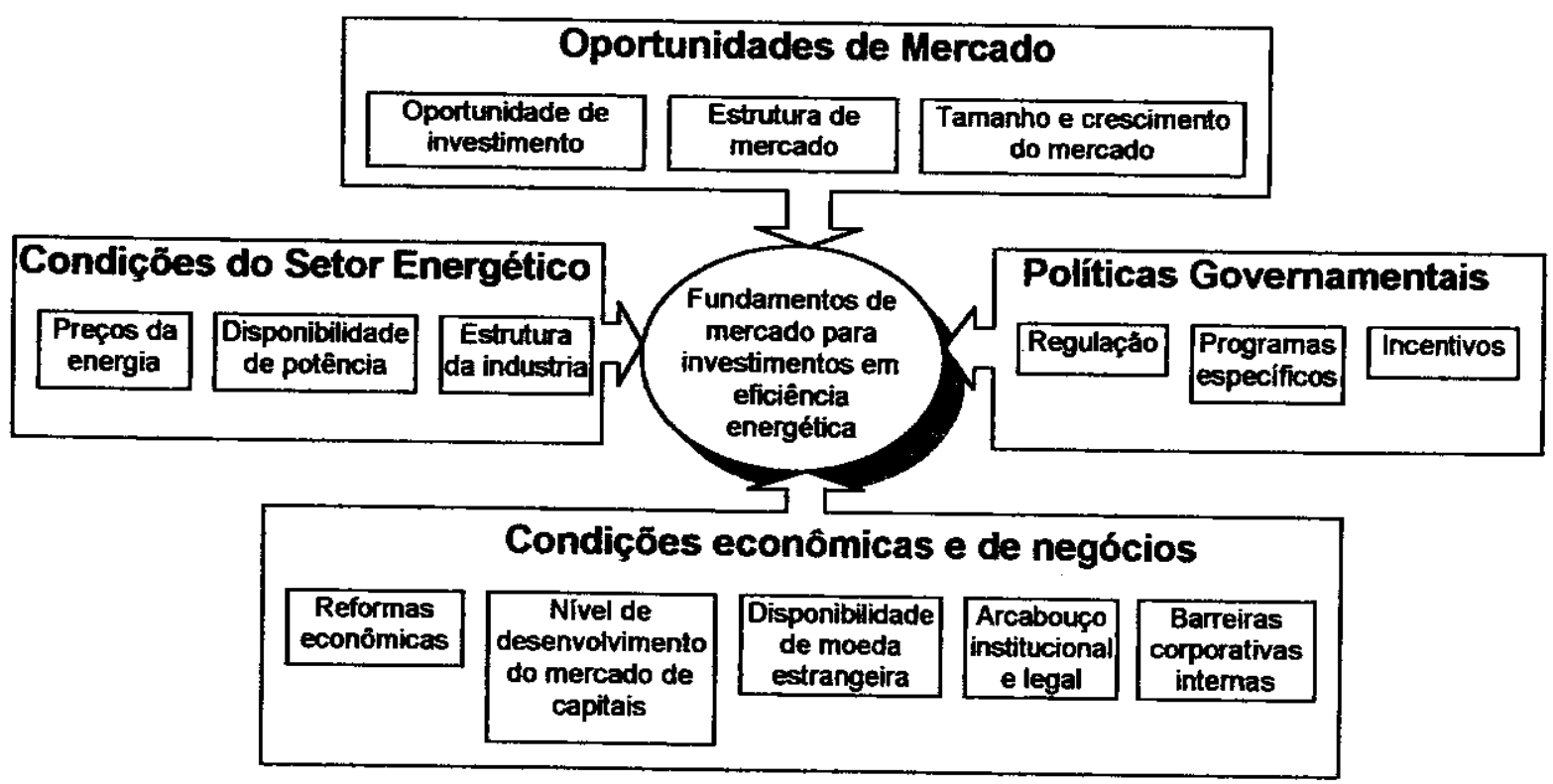

Figura 4.1 Fundamentos de mercado para eficiência energética.

Fonte: USAID (1996). 


\section{Barreiras}

REDDY (1991) lista seis barreiras que dificultam a implementação da eficiência energética:

- desconhecimento dos consumidores sobre as melhores tecnologias e os custos/beneficios a elas associados;

- sensibilidade ao custo inicial dos equipamentos eficientes;

- indiferença de alguns consumidores, em virtude do custo da energia não ser um item fundamental nas suas despesas;

- indisponibilidade de determinados equipamentos na indústria;

- incerteza quanto aos preços futuros da energia e de equipamentos, e

- herança da ineficiência, em razão de decisões anteriormente tomadas.

A eficiência energética também enfrenta barreiras institucionais que podem inviabilizar a implementação de políticas mais eficazes. O BANCO MUNDIAL (1993) aponta, nos países em desenvolvimento, as seguintes:

- não repasse dos preços internacionais da energia;

- suprimento a cargo de monopólios estatais subsidiados;

- estrutura de mercado não competitiva e preços subsidiados da energia;

- estruturas juridicas inadequadas;

- falta de códigos e normas ou incapacidade para fazer cumpri-las e,

- impostos e subsídios discriminatórios.

O Banco Mundial entende que empreender esforços contínuos visando solucionar os problemas institucionais e de política nacional é a melhor maneira de obter maiores avanços para a eficiência energética, e recomenda a adoção das seguintes estratégias: 
- Precos da energia: a eliminação dos subsidios tarifários se constitui numa das prioridades para a eficiência energética, haja vista que tarifas muito baixas desencorajam os investimentos em novas tecnologias menos poluidoras e em processos de maior rendimento energético, sendo, portanto, ineficiente dos pontos de vista ambiental e econômico;

Se essa visão do Banco Mundial for correta, também há que se considerar do ponto de vista da sociedade, como eliminar os subsídios sem dificultar o acesso aos serviços de energia elétrica. Se por um lado eles representam uma barreira para a implantação da eficiência energética, por outro, proporcionam maior acesso aos serviços de energia elétrica às classes de menor renda.

- Reforma institucional referente à oferta;

- Mercados competitivos: intermediação do mercado (reduzir custos altos com informação, gestão, tecnologia e transações financeiras): proporcionar a produtores e consumidores os exemplos e a informação técnica, econômica e financeira que necessitam para tomar decisões sobre produção e consumo de energia;

- Transferência de tecnologia: introduzir novos produtos, tecnologias e processos que melhorem a eficiência e reduzam a poluiçăo, tanto no lado das oferta quanto dos usos finais.

RAAD (1999), numa análise sobre a tipologia de barreiras para eficiência energética, propõe que elas sejam classificadas em barreiras tecnológicas; econômicas; culturais, comportamentais e institucionais. 


\subsection{Oportunidades para eficiência energética na iluminação pública}

\section{a) Redução das despesas com energia elétrica}

A escassez de recursos fiscais que atinge sobretudo os pequenos municipios brasileiros, é um fato que vem sendo bastante debatido no país. Se por um lado ela causa graves conseqüências financeiras, por outro, pode contribuir para a racionalização dos gastos públicos, ao impor uma gestão mais rigorosa das finanças e a busca de maiores indices de eficiência e produtividade.

No Brasil, estima-se que a despesa das prefeituras municipais somente com o consumo de energia elétrica da iluminação pública, chega a representar, em média, mais de $70 \%$ da despesa total com energia elétrica (ELETROBRÁS, 1998).

Com a privatização do setor elétrico brasileiro os preços das tarifas de energia elétrica tendem a aumentar, não só em decorrência da eliminação dos subsídios tarifários, mas pela busca de maximização dos lucros por parte das concessionárias. Nesse contexto, as despesas com energia elétrica podem assumir um peso relevante, onerando ainda mais o orçamento dos municípios, e a eficiência energética é uma oportunidade efetiva de economia de energia elétrica e, conseqüentemente, de redução de gastos.

\section{b) Redução dos custos de manutenção}

Nos capítulos 2 e 3 mostrou-se que tanto as concessionárias quanto os municípios são proprietários dos sistemas de iluminação pública. Quando as concessionárias são responsáveis pelos serviços de manutenção, inclusive seus custos, cobram das prefeituras municipais a tarifa B4b. Nesse caso, as concessionárias têm interesse de reduzir os custos de manutenção, pois dessa forma estarão 
aumentando a margem de remuneração desse serviço. O mesmo ocorre quando os sistemas de IP pertencem ao município. Portanto, em ambos os casos, a melhoria da eficiência energética do sistema de iluminação pública pode proporcionar a redução do custos de manutenção com a utilização de tecnologias eficientes.

\section{c) Facilidade operacional de implantação}

Um fator facilitador das medidas de eficiência energética na iluminação pública é a sua relativa simplicidade técnica e operacional de execução. Em alguns casos, apenas com a substituição de lâmpadas obsoletas por outras mais eficientes, é possivel reduzir o consumo de energia elétrica e obter uma iluminação de melhor qualidade.

\section{d) Melhoria da imagem das cidades}

Além da importância para a segurança do tráfego de pedestres e de veículos, a iluminação pública é um dos vetores para o desenvolvimento econômico do município. A iluminação de áreas de valor histórico, artístico, cultural e ambiental, por exemplo, pode contribuir para melhorar e difundir a imagem noturna da cidade, dotando-a de uma identidade própria e aumentando o grau de satisfação e conforto dos cidadãos.

\section{e) Postergação de investimentos no sistema elétrico e redução dos impactos sociais e ambientais}

A implementação de medidas para eficiência energética podem postergar investimentos em novos empreendimentos energéticos, na medida em que a 
redução de demanda e a energia evitada possibilitam o atendimento de consumidores adicionais sem a necessidade de expansão do sistema no curto prazo.

No caso dos projetos direcionados para o uso final, a exemplo da iluminação pública, os benefícios se refletem em todos os segmentos a montante do sistema elétrico, contribuindo para uma melhor utilização das instalaçōes desde a distribuição de energia elétrica até a geração.

A postergação de investimentos em novas usinas de geração de energia elétrica e nos respectivos sistemas de transmissão e distribuição associados, contribui também para a redução dos impactos ambientais e sociais, e para utilização mais racional dos recursos energéticos.

\subsection{Barreiras para eficiência energética na iluminação pública}

\section{a) Elevado custo inicial das tecnologias eficientes}

As tecnologias energeticamente eficientes de iluminação pública estão identificadas e disponíveis no mercado brasileiro. Porém, a elevada diferença entre os custos dos equipamentos eficientes e os convencionais é um obstáculo, principalmente para os pequenos municípios. Além disso, os compradores geralmente não estão preparados para realizarem uma adequada análise do custo do ciclo de vida dos equipamentos, incluindo os gastos com energia elétrica e reposição. 


\section{b) Falta de informação e de cultura para o combate ao desperdício}

A iluminação pública é um setor que apresenta significativo potencial de conservação de energia. A implementação de programas de eficiência energética pode proporcionar, em média, uma economia da ordem de $30 \%$ a $40 \%$ nos custos operacionais (ELETROBRÁS, 1998).

Entretanto, a falta de informação sobre as melhores tecnologias, as linhas de financiamento disponíveis e a própria falta de cultura para o combate ao desperdício, dificultam a tomada de decisão dos agentes. Além desses fatores, a falta de capacitação técnica impede o convencimento sobre os benefícios técnicos e econômicos proporcionados pelos equipamentos energeticamente eficientes.

\section{c) Conflitos institucionais}

Os conflitos entre municípios e concessionárias analisados no capítulo 2, principalmente os relacionados com a propriedade das instalaçōes dos sistemas de iluminação pública e os limites de atuação de cada um, podem dificultar a implementação da eficiência energética.

Ou seja, nos municípios onde a questão patrimonial das instalaçōes de iluminação pública não está regularizada com a concessionária por meio de instrumentos legais, ou quando elas pertencem a ambos, não fica claro quem é a entidade responsável pelos investimentos.

\section{d) Dificuldades de acesso aos financiamentos}

Do ponto de vista econômico-financeiro os investimentos em eficiência energética na iluminação pública podem apresentar taxas internas de retorno bastante 
elevadas (BURINI et al, 1993). No entanto, as atuais condiçōes de mercado para financiamento ao setor público de alguma forma se tornam impraticáveis, seja pelas altas taxas de juros cobradas, seja pelas exigências de garantias, que os municipios não têm condiçōes de oferecer.

No caso dos pequenos municipios, o acesso aos financiamentos é ainda mais dificil. Ademais, a principal linha de financiamento para conservaçăo de energia elétrica, sob a gestão da ELETROBRÁS/PROCEL, só está disponivel para as concessionárias.

\section{e) Inadimplência dos municípios}

A histórica inadimplência de alguns municipios no pagamento das contas de energia elétrica da iluminação pública, tem dificultado as negociações e inviabilizado a execução de projetos de eficiência energética pelas concessionárias.

Não somente os projetos financiados pela ELETROBRAS/PROCEL, mas os investimentos obrigatórios em eficiência energética de que trata a Resolução 261/99 da ANEEL, são realizados pelas concessionárias. Portanto, os municipios inadimplentes, geralmente são excluídos dos programas de eficiência energética da iluminação pública por elas executados.

\section{f) Redução do faturamento da concessionária}

Grande parte das concessionárias de distribuição considera que investir em eficiência energética no usos finais não é um negócio atrativo. O principal argumento utilizado é que há redução do montante de energia elétrica faturada no curto prazo. Por outro lado, é preciso analisar até que ponto as perdas de receita 
podem ser atenuadas pela venda da energia economizada a outras classes de consumidores com tarifas mais atrativas.

\subsubsection{O programa nacional de conservação de energia elétrica - PROCEL}

Em 1985 foi instituído no Brasil o Programa Nacional de Conservação de Energia Elétrica - PROCEL, com a finalidade de integrar açōes e viabilizar o significativo potencial de conservação de energia elétrica existente no país ${ }^{27}$.

As diretrizes de atuação do PROCEL são estabelecidas pelo Grupo Coordenador de Conservação de Energia Elétrica - GCCE, e a execução das políticas são implementadas pela ELETROBRÁS, que exerce a função de secretaria executiva do programa.

O principal objetivo do PROCEL é combater o desperdício de energia elétrica no lado da oferta (produção) e no lado da demanda (consumo), contribuindo para melhorar a qualidade de produtos e serviços, reduzir os impactos ambientais e fomentar a geração de empregos.

No caso da iluminação pública, os principais objetivos são reduzir a demanda máxima do sistema elétrico no horário de pico; modernizar e melhorar a eficiência energética dos sistemas de iluminação pública; promover a gestão eficiente dos sistema de IP e incentivar o desenvolvimento tecnológico de equipamentos de IP.

As principais estratégias do PROCEL para alcançar esses objetivos são as seguintes: 
- assegurar a disponibilidade de recursos da RGR para o financiamento de projetos de melhoria da eficiência energética de sistemas de I.P e estabelecer parcerias com outros órgãos financiadores;

- incentivar a ação das Empresas de Serviços Energéticos - ESCO's, para realização de contratos de perfomance junto às prefeituras municipais e concessionárias;

- promover a instalação de equipamentos eficientes, a partir de índices mínimos de eficiência.

\section{Financiamento dos projetos de iluminacão pública}

A principal fonte de recursos para financiamento de projetos para eficiência energética e conservação de energia elétrica no Brasil é proveniente da Reserva Global de Reversão - RGR, uma quota anual incidente sobre o investimento das concessionárias, com a finalidade de criar um Fundo de Reversão para aplicação em encampação, expansão e melhoria dos serviços públicos de energia elétrica ${ }^{28}$.

Os montantes a serem financiados são limitados através de percentuais sobre o valor total do projeto, de acordo com as regiōes geográficas do país: Sistema Interligado Sul/Sudeste - até 50\%; Sistema Interligado Centro-Oeste - até 50\%; Sistema Interligado Norte/Nordeste - até $60 \%$, e Sistemas Isolados, até $70 \%$ (ELETROBRAS, 1997).

\footnotetext{
28 A ELETROBRÁS, por imposiçăo da Lei No 8.631/93, foi obrigada a destinar parte dos recursos da RGR para reativaçăo do programa nacional de conservaçăo de energia elétrica. Essa lei estabeleceu que a quota anual de reversão corresponderia ao produto de até $3 \%$ incidente sobre o investimento do ativo imobilizado em serviço de cada concessionário. O Decreto $\mathfrak{n}^{\circ} 774$, de 18 de março de 1993 , que regulamentou a Lei 8.631 , fixou os percentuais em 1,5\%, até 30 de setembro de 1993, e em 3\% a partir de 1 de outubro de 1993 , observado o limite de $12 \%$ da receita anual do concessionário. Com a edição da Lei No 9.427/96, que instituiu a ANEEL, a quota anula de reversão passou a ser de até $2,5 \%$ sobre os investimentos das concessionárias, limitada em $3 \%$ da receita anual.
} 
As condiçōes financeiras são as seguintes: prazo de carência de até 24 meses, contados a partir da assinatura do contrato; prazo de amortização de até 3 anos, contados a partir do término do prazo de carência; taxa de juros de $5 \%$ a.a., mais taxa de administração de $1 \%$ a.a. sobre o saldo devedor corrigido (ELETROBRÁS, 1997). Os financiamentos realizados pela ELETROBRÁs através do PROCEL só podem ser concedidos diretamente às concessionárias de energia elétrica ${ }^{29}$.

De acordo com a Art. $8^{\circ}$ da Lei $N^{\circ} 9.648$, de 27 de maio de 1998, a cota anual da RGR deverá ser extinta em 2002 e a ANEEL deverá proceder à revisão tarifária para que os consumidores sejam beneficiados com essa medida.

\section{Projetos financiados pelo PROCEL}

Até 1998 a ELETROBRÁS, através do PROCEL, financiou projetos para melhoria da eficiência energética de cerca de 2,48 milhões de pontos de iluminação pública. A tabela 4.6 apresenta os resultados detalhados, por região do país.

TABELA 4.6 Projetos de IP financiados com recursos da RGR.

\begin{tabular}{|c|c|c|c|c|c|}
\hline fecto & 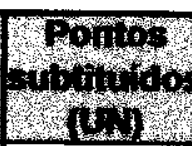 & 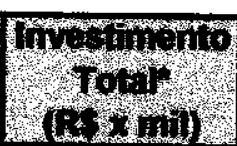 & $\begin{array}{l}\text { Terowerto } \\
\text { de ormand }\end{array}$ &  & $\begin{array}{l}\text { Tros } \\
\text { Municipios } \\
\text { atenitisos }\end{array}$ \\
\hline NORDESTE & 894.054 & $60.458,61$ & 287.225 & 65,86 & $\frac{92}{92}$ \\
\hline NORTE & 153.535 & 131,59 & 72 & 8,11 & \\
\hline CENTRO-OESTE & 359.812 & $33.032,40$ & 152.979 & 34,74 & 249 \\
\hline & 869.249 & $66.795,63$ & 278.990 & 04 & 308 \\
\hline SUDESTE & & $39.751,27$ & 170.996 & 29,43 & 24 \\
\hline Tor & 2483146 & 214.6950 & 925362 & 20 & 727 \\
\hline
\end{tabular}

Fonte: Araújo et al (1999).

"Financiamento com recursos da RGR: R\$ 114 milhões. 


\section{Metas}

As metas previstas pelo PROCEL para o periodo 2000-2002, incluem:

- investimentos da ordem de 900 milhões de reais para melhoria da eficiência energética de 8,0 milhões de pontos de iluminação pública distribuidos nas diversas regiões do país;

- redução de $540 \mathrm{MW}$ na demanda;

- consumo evitado de energia elétrica da ordem de 2.400 GWh/ano;

- economia equivalente a 1,45 bilhão em investimentos na geração, transmissão e distribuição de energia elétrica (PROCEL, 1999).

\subsubsection{Legislação de incentivo à eficiência energética no Brasil}

Atualmente o Brasil dispōe de um razoável arcabouço legal destinado a criar as condições institucionais, fomentar e estimular o desenvolvimento de ações para o combate ao desperdicio de energia elétrica e promoção da eficiência energética, compreendendo a produção e o consumo final de energia elétrica.

\section{Portaria DNAEE 185/88 - Renegociacão dos contratos de fornecimento}

Em consonância com os objetivos do PROCEL o DNAEE editou, em 1988, a Portaria 185, que determina aos concessionários a renegociação dos contratos de fornecimento de energia elétrica, sempre que solicitados por consumidores que implementarem medidas de conservação de energia elétrica que redundem em redução de carga. 
Para tanto, os consumidores devem submeter ao concessionário as medidas de conservação a serem adotadas com as devidas justificativas técnicas, etapas de implantação, resultados previstos, prazos, e base para a revisão do contrato de fornecimento e acompanhamento pelo concessionário. Da mesma forma, as reduções dos valores de demanda contratada que tenham repercussões nos contratos de suprimento, devem ser considerados nos estudos de mercado de curto e longo prazos.

\section{Programa Nacional de Racionalizacão da Producão e do Uso de Energia}

Em 1990 o governo federal instituiu o Programa Nacional de Racionalização da Produção e do Uso de Energia, com o objetivo de promover, articular e desenvolver ações visando à racionalização e maior eficiência na produção e no uso de insumos energéticos no país ${ }^{30}$.

Esse programa é coordenado pelo Ministério de Minas e Energia , e o GERE Grupo Executivo do Programa Nacional de Racionalização da Produção e do Uso de Energia, é o órgão que tem as atribuições de propor as diretrizes gerais para a conservação de energia do pais e orientar o desenvolvimento dos programas de racionalização da produção e conservação de energia existentes em todos os niveis de governo.

\section{$\underline{\text { Selo verde - Incentivo ao desenvolvimento de equipamentos eficientes }}$}

No dia 8 de dezembro de 1993 foi instituído o Selo Verde de Eficiência Energética, com o objetivo de identificar os equipamentos que apresentem altos níveis de

\footnotetext{
30 Este Programa foi criado pelo Decreto $\mathrm{N}^{\circ} 99,250$, de 11 de maio de 1990 , sendo atualmente regido pelo Decreto de 21 de setembro de 1990.
} 
eficiência energética. Essa medida também visou promover o reconhecimento público dos esforços da indústria nacional para dotar os seus produtos de índices de eficiência energética semelhantes aos internacionais.

\section{Prêmio nacional de conservacão e uso racional de energia}

Ainda em 1993, foi instituído o Prêmio Nacional de Conservação e Uso Racional de Energia, destinado ao reconhecimento das contribuições em prol da conservação e uso racional de energia no país, incluindo órgãos e empresas da administração pública, empresas do setor energético, indústrias, empresas comerciais e de serviços, micro e pequenas empresas, edificações, transporte e reportagens.

Um dos principais objetivos desse prêmio é motivar a sociedade para mudanças de atitudes com vistas ao combate ao desperdício de energia elétrica e estimular a competição entre empresas para melhoria da eficiência energética de seus produtos.

\section{Portaria DNAEE No 730 - A eficiência energética no custo do servico}

Também em 1993 o DNAEE editou a Portaria 730, com o objetivo de incentivar investimentos por parte das concessionárias em conservação de energia e eficiência energética. Por esse instrumento, as concessionárias de serviço público de energia elétrica passam a ser autorizados a computar no custo do serviço ou no investimento remunerável, os gastos com o custeio e investimentos relativos a programas de incremento da eficiência no uso e na oferta de energia elétrica. 


\section{Apoio ao financiamento para conservação de energia}

Em 11 de janeiro de 1994, o governo federal estabeleceu outro importante marco para a conservação de energia no Brasil com a edição do Decreto $n^{0} 1.040$. Esse decreto obriga aos agentes financeiros oficiais incluir, entre as linhas prioritárias de crédito, os projetos destinados à conservação e uso racional de energia e ao aumento da eficiência energética, inclusive os projetos de pesquisa e desenvolvimento tecnológico nessas áreas. O BNDES, por exemplo, já dispõe de linhas que incluem financiamentos para projetos de eficiência energética.

\section{A eficiência energética regulamentada pela ANEEL}

As concessionárias de distribuição de energia elétrica do Brasil estão obrigadas a implementar projetos de melhoria da eficiência energética pelo lado da demanda e pelo lado da oferta. A Resolução № 261 da ANEEL, de 3 de setembro de 1999, regulamenta a obrigatoriedade de aplicação de recursos das concessionárias para o combate ao desperdício de energia elétrica e para pesquisa e desenvolvimento tecnológico durante o biênio 1999/2000. Também estabelece que elas devem aplicar anualmente, no mínimo, $1 \%$ da sua receita operacional líquida do ano anterior.

Para as concessionárias cuja receita operacional líquida é superior a $R \$$ $1.000 .000,00$ (um milhão de reais), a resolução fixa limites mínimos para aplicação especifica em determinados tipos de projetos. Nesses casos, no mínimo $0,25 \%$ da receita operacional líquida deve ser aplicado no uso final da energia elétrica. 


\subsection{Conclusões}

O aumento da eficiência energética tem sido reconhecido em todo o mundo como um dos fatores significativos para conciliar o desenvolvimento sustentável com o atendimento às crescentes necessidades energéticas. Também contribui para minimizar os impactos sociais e ambientais e para preservar os recursos econômicos e energéticos da sociedade.

Mesmo em face das oportunidades para eficiência energética no setor de iluminação pública no Brasil, sobretudo os municípios - principais atores da iluminação pública e responsáveis legais pela organização e prestação desses serviços - enfrentam várias barreiras. Entre as mais relevantes, identificam-se as dificuldades de financiamento direto para os programas de conservação de energia elétrica, a falta de informação sobre as tecnologias eficientes e os custos e benefícios a elas associados, e as resistências ainda existente nas concessionárias de energia elétrica.

O PROCEL tem desenvolvido ações importantes para o desenvolvimento da eficiência energética no Brasil, particularmente, na iluminação pública, e o país dispõe de um razoável aparato legal de incentivo à eficiência energética. Entretanto alguns instrumentos precisam ser postos em prática, a exemplo da Portaria DNAEE 730/93, que não se tem registro de sua eficácia ou aplicação por parte das concessionárias.

É também necessária a participaçăo de todos os atores envolvidos neste setor, a fim de que o significativo potencial de conservação de energia elétrica na iluminação pública seja viabilizado economicamente. Para tanto é preciso difundir as tecnologias eficientes disponíveis no mercado brasileiro e estabelecer mais opções de financiamento, com uma maior participação de agentes públicos e privados. 


\section{AVALIAÇÃO TÉCNICO-ECONÔMICA DE PROJETOS PARA EFICIÊNCIA ENERGÉTICA DE SISTEMAS DE ILUMINAÇÃO PÚBLICA}

\subsection{Classificação de projetos de investimentos}

A análise de viabilidade técnico-econômica de projetos de investimentos devem ser realizadas sob o ponto de vista de cada ator, incluindo não só a avaliação dos beneficios financeiros e econômicos, mas as externalidades, a exemplo dos impactos socais e ambientais.

Para CONTADOR (1997) as externalidades importam para as pessoas e as empresas da mesma forma que os bens e serviços com preço corrente no mercado, pois afetam o bem-estar e o lucro. Ele propõe uma classificação esquemática para mostrar a atratividade de projetos para o empreendedor, ponto de vista privado, e para a sociedade, ponto de vista social, conforme mostrado na figura 5.1.

\begin{tabular}{l|c|c|c}
\hline \multicolumn{2}{c|}{} & \multicolumn{2}{c}{ Ponto de Vista Social } \\
\cline { 3 - 4 } & + & - \\
\hline $\begin{array}{l}\text { Ponto de vista } \\
\text { Privado }\end{array}$ & + & I & II \\
\cline { 2 - 4 } & - & III & IV \\
\hline
\end{tabular}

Figura 5.1 Atratividade de projetos de investimentos.

Fonte: CONTADOR (1997).

O sinal positivo indica que o projeto é viável, e o negativo, inviável. Os projetos da célula I são viáveis tanto do ponto de vista privado, quanto do social, e num mercado de livre concorrência e de liberdade econômica, o empreendedor se interessa em implementá-lo sem intervenção do governo. Os projetos da célula II 
são atrativos para o empreendedor, mas não trazem benefícios para a sociedade. Nesses casos, ou se aceita as perdas sociais em prol da livre iniciativa, estimulo ao espírito empresarial ou diferença dos preços sociais e de mercado impostas ao investidor, ou adota-se mecanismos de desestímulo para sua implantação por meio de políticas tributárias e/ou regulamentação (CONTADOR, 1997).

Ainda pela análise de Contador, os projeto do tipo III não são atrativos do ponto de vista do empreendedor, mas são viáveis do ponto de vista da sociedade. Nesse caso, o empresário somente implantará o projeto se for estimulado por meio de isençōes fiscais e/ou créditos subsidiados. Por fim, os projetos da célula IV são inviáveis sob as óticas privada e social, e não devem ser implantados.

Os projetos para melhoria da eficiência energética de sistemas de iluminação pública, geralmente, apresentam características semelhantes às dos projetos tipo $I$ e tipo III. Pela teoria apresentada, para viabilizar a melhor opção do ponto de vista privado nos casos dos projetos tipo III, seria necessária a intervenção do governo com a concessão de incentivos financeiros ao investidor.

\subsection{Os principais atores da iluminação pública: papéis e motivações}

Os principais atores na organização e prestação dos serviços de iluminação pública são os municípios e as concessionárias de energia elétrica. No financiamento da eficiência energética destacam-se o governo federal, representado pelo PROCEL, e os bancos multilaterais de desenvolvimento, ainda com atuação incipiente nessa área no Brasil.

Como micro atores podem ser considerados os usuários locais dos serviços, a indústria de equipamentos, as ESCO's e também os bancos multilaterais de 
desenvolvimento. A figura 5.2 apresenta um esquema identificando os macro e micro atores da iluminação pública e suas motivaçōes.

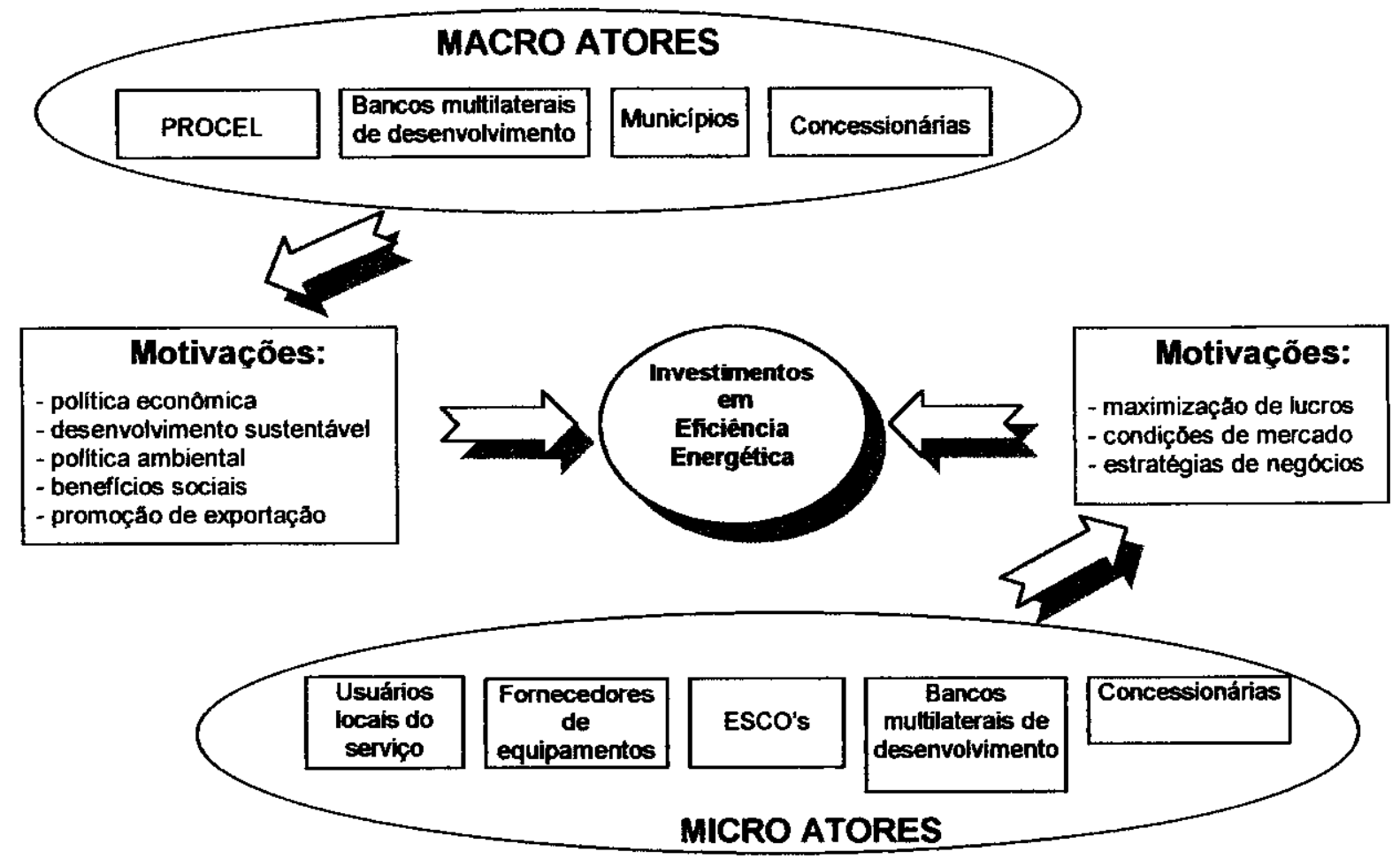

Figura 5.2 Os atores da iluminação pública e suas motivações.

Fonte: USAID (1996). Adaptado.

Além das motivaçōes de ordem geral, os municípios, as concessionárias e os usuários do serviços, de um modo particular, têm motivaçōes específicas para implementação da eficiência energética na iluminação pública, inerentes ao papel desempenhado por cada um deles.

\section{a) Municípios}

Um dos principais papéis dos Municípios é promover o bem-estar da população com a organização e prestação dos serviços públicos de interesse local, entres os quais, a iluminação pública. Considerando que a iluminação pública necessita do 
fornecimento de energia elétrica, eles também são clientes das concessionárias e assumem as obrigações de comprar e pagar a energia elétrica.

Na perspectiva dos municípios, a melhoria da eficiência energética da iluminação pública pode ser atrativa, do ponto de vista financeiro, se os investimentos forem recuperados durante a vida do projeto, pela redução dos custos operacionais: consumo de energia elétrica e manutenção do sistema de IP. Por outro lado, além dos resultados financeiros, os municípios esperam garantir uma iluminação pública moderna, eficiente e com melhor qualidade, o que poderá proporcionar benefícios econômicos e sociais para a população.

\section{b) Concessionárias de energia elétrica}

No Brasil, as concessionárias de energia elétrica apresentam diferentes tipos de estrutura. Existem empresas que produzem e transmitem eletricidade; as que são apenas distribuidoras e as verticalmente integradas, ou seja, as que são simultaneamente responsáveis pela geração, transmissão e distribuição de energia elétrica. A partir de 1998 foi regulamentada a nova atividade de comercialização de energia elétrica. ${ }^{29}$

Neste trabalho as análises econômicas foram realizadas especificamente sob a ótica da concessionária distribuidora. As distribuidoras geralmente compram energia das empresas geradoras e a vendem no mercado varejista final da sua área de concessão ou, excepcionalmente, a consumidores livres. O principal papel de uma concessionária distribuidora de energia elétrica é obter lucro com o

29 O Decreto $\mathrm{N}^{\circ} 2.655$ de 02 de julho de 1998, que regulamenta o Mercado Atacadista de Energia Elétrica - MAE, estabelece no seu artigo $1^{\circ}$ que "a exploração dos serviços e instalaçôes de energia elétrica compreende as atividades de geração, transmissão, distribuiçăo e comercializaçāo". As condiçōes para o exercicio das atividades de comercialização foram regulamentadas através da Resoluçāo ANEEL $\mathrm{N}^{\circ} 265$, de 13 de agosto de 1998 . 
fornecimento de energia elétrica aos consumidores finais, garantindo atendimento da demanda durante todo o tempo, com qualidade, continuidade e segurança. ${ }^{30}$

\section{c) Usuários locais}

Os habitantes das cidades - usuários locais e beneficiários da iluminação pública geralmente pagam diretamente por esse serviço por intermédio da TIP, ou no IPTU. Eles esperam que os investimentos em eficiência energética promovam a melhoria da iluminação pública e que as taxas ou quaisquer encargos pagos, sejam reduzidos. A expectativa dos usuários é reforçada pela própria motivação do município, que espera diminuir os seus gastos com o sistema de iluminação pública, o que permitiria repartir os beneficios com eles.

\subsection{Estudo de caso: iluminação pública da cidade João Pessoa}

\subsubsection{Caracterização da área de estudo}

João Pessoa, capital da Paraiba, possui cerca de 600 mil habitantes (SEPLAN, 1999). O fornecimento de energia elétrica é realizado pela Sociedade Anônima de Eletrificação da Paraíba - SAELPA, concessionária estadual de distribuição de energia elétrica que atende $96 \%$ dos municípios do Estado.

O consumo de energia elétrica em iluminação pública na área de concessão da SAELPA, em 1999, foi de 125.853 MWh. A cidade de João Pessoa participou com $25.170 \mathrm{MWh}$, ou seja $20 \%$ desse consumo, equivalente a $1,25 \%$ de toda energia elétrica consumida na área da SAELPA naquele ano. $O$ mercado de energia

30 A legislação permite ao concessionário vender energia elétrica para consumidores especiais fora de sua área de concessão. Os critérios săo estabelecidos na Resolução ANEEL Nº 264, de 13 de agosto de 1998. 
elétrica da SAELPA, por participação das classes de consumidores, apresenta a seguinte composição:

TABELA 5.1 Consumo de energia elétrica por classes na área da SAELPA.

\begin{tabular}{|c|c|}
\hline CLASSE & coNSUN O (MW h) \\
\hline Residencial & 716.350 \\
\hline Ind ustrial & 609.903 \\
\hline comercial & 267.588 \\
\hline R u r a I & 78.438 \\
\hline$P$ od er $P$ ú b lico & 101.111 \\
\hline I. $P$ ú b fic a & 125.835 \\
\hline Serviço P ú b lico & 109.710 \\
\hline Próprio & 13.685 \\
\hline TOTAL & 2.022.620 \\
\hline
\end{tabular}

Fonte: Relatório de Mercado da SAELPA, 1999.

A participação percentual das classes no consumo total da SAELPA é mostrada na figura 5.3 , onde observa-se a iluminação pública contribuindo com $6 \%$.

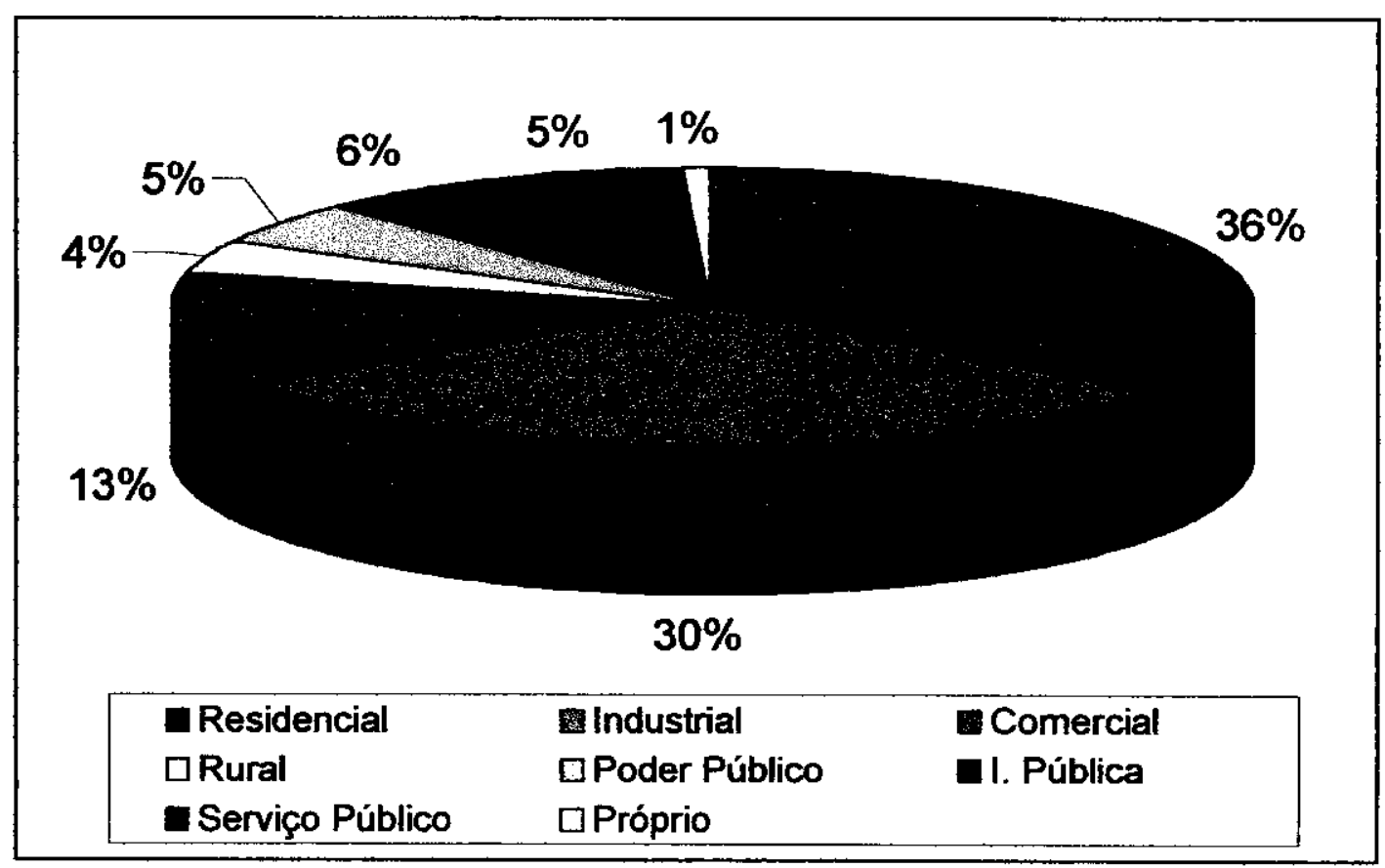

Figura 5.3 Participação das classes de consumo no mercado da SAELPA. Fonte: Relatório de Mercado da SAELPA, 1999. 


\subsubsection{Figuras de mérito econômico e premissas adotadas}

\section{Tempo de Retorno Simples - TRS}

O TRS é calculado pela diferença entre o investimento inicial para implantar o novo sistema e o investimento que seria necessário para repor o sistema existente, dividida pela economia anual de energia elétrica:

$$
\text { TRS }=\frac{(I E-I C)}{P E^{*}(E C-E E)}
$$

onde,

$\mathbb{E}=$ Investimento inicial no sistema eficiente, $[R \$]$;

IC = Investimento para repor o sistema existente (a ser substituído), [R\$];

$P E=$ Preço da energia elétrica, $[R \$ / M W h] ;$

$E C=$ Consumo de energia do sistema a ser substituído, [MWh/ano];

$\mathrm{EE}=$ Consumo de energia do sistema eficiente, [MWh/ano].

A vantagem do TRS é a simplicidade e o cálculo imediato. Entretanto é uma figura que apresenta limitações, pois não considera o valor temporal do dinheiro; ignora os fluxos previstos após o periodo de retorno; não esclarece por si qual o valor mínimo de retorno exigido para aceitação do projeto; ignora a escala do projeto; e em projetos que apresentam fluxos de caixa com várias mudanças de sinal, é falho no auxílio ao processo decisório (CONTADOR, 1997). 


\section{Taxa Interna de Retorno - TIR}

A Taxa Interna de Retorno (TIR) é o valor da taxa de desconto que torna o Valor Presente Líquido do fluxo de caixa de investimentos nulo. Se a TIR obtida é igual ou maior que a taxa de juros do financiamento, o projeto é viável.

O cálculo da TIR prescinde de informaçōes externas ao projeto, porém apresenta as desvantagens de pressupor constante a taxa de desconto ao longo do tempo e a possibilidade de raízes múltiplas. Ademais, não diferencia escala dos projetos $\mathrm{e}$ não deve ser usado como critério de decisão em projetos "não-convencionais" ou mal comportados (CONTADOR, 1997).

\section{Valor Presente Líquido - VPL}

O VPL corresponde à soma algébrica dos valores do fluxo de caixa do projeto, atualizados à taxa de desconto escolhida. O projeto será viável se o VPL for positivo (CONTADOR, 1997).

\section{Custo do Ciclo de Vida - CCV}

O CCV é calculado pela soma do valor presente de todos os custos do projeto: investimento inicial, gastos com energia elétrica e gastos com reposição, subtraída dos valores residuais dos equipamentos.

$$
\operatorname{CCV}=\mathbf{l o}+\left(\frac{\mathrm{Ge}}{\operatorname{FRC}(\mathbf{i}, \mathbf{n})}\right)+\left(\frac{\mathrm{Gi}}{\operatorname{FRC}(\mathbf{i}, \mathbf{n})}\right)-\left(\frac{\mathrm{Vr}}{(1+i)^{N}}\right)
$$

onde: 
lo = Investimento inicial, $[\mathrm{R} \$$;

CCV = Custo do Ciclo de Vida, $[R \$]$;

$\mathbf{G e}=$ Gastos com energia elétrica, $[R \$ / a n o] ;$

$\mathbf{G i}=$ Gastos com equipamentos, $[\mathrm{R} \$ / \mathrm{ano}]$;

$\mathrm{Vr}=$ Valor residual, $[R \$]$;

$\mathbf{n}=$ Vida esperada dos equipamentos, [anos];

$\mathbf{N}=$ Periodo de estudo, [anos].

Para anualização dos valores, utilizou-se o Fator de Recuperação de Capital, dado por:

$$
F R C=\frac{r}{\left[1-(1+r)^{-n j}\right]},
$$

onde,

$r=$ taxa de desconto efetiva;

$\mathbf{n j}=$ vida útil de cada equipamento $\mathbf{j}$, em anos;

\section{Custo do Ciclo de Vida Anualizado - CCVA}

o CCVA é calculado pelo custo do ciclo de vida do projeto - CCV, multiplicado pelo fator de recuperação de capital:

$$
C C V A=C V V * F R C(i, N)
$$

\section{Custo da Energia Economizada - CEE}

O CEE é calculado pela diferença entre os custos dos ciclos de vida anualizados (CCVA) da tecnologia eficiente e a tecnologia existente (a ser substituída), dividida pela estimativa economia de energia elétrica, conforme a expressão 5.4 . 


$$
\mathrm{CEE}=\frac{[\text { CCVA(eficiente) }- \text { CCVA(existente })]}{(\mathrm{EC}-\mathrm{EE})},
$$

\section{Relacão Beneficio / Custo - RBC}

$\mathrm{Na}$ análise do ponto de vista da sociedade, foram comparados os custos do projeto de eficiência com os custos unitários evitados de potência e energia elétrica, de acordo com a seguinte Relação Benefício / Custo - RBC (ANEEL, 1999).

$$
\mathrm{RBC}=\frac{\mathrm{CDE}}{\text { CCVANE}} \text {, onde }
$$

CDE = Custos unitários de demanda e energia evitados, dados por

CDE = CUE * EE + CUD * DME , (5.5.1), onde

CUE $=$ Custo unitário de energia evitada, $[R \$ / M W h] ;$

EE = Energia evitada em um ano, [MWh];

CUD = Custo unitário de demanda evitada, $[R \$ / k W . a n o] ;$

DME = Demanda máxima evitada em um ano, [kW].

e CCVANE $=\left\{l o+\left(\frac{G i}{\operatorname{FRC}(i, n)}\right)-\left(\frac{V r}{(1+i)^{N}}\right)\right\}^{*} \operatorname{FRC}(i, N)$,

O CCVANE - Custo do Ciclo de Vida Anualizado Nāo Energético, representa todos os custos anualizados, de acordo com vida útil de cada equipamento, excluídos os gastos com energia elétrica, onde:

$$
\begin{aligned}
& \mathbf{l o}=\text { Investimento inicial, }[R \$] ; \\
& \text { Gi = Gastos com equipamentos, }[R \$ / a n o]
\end{aligned}
$$




$$
\begin{aligned}
& \mathbf{V} \mathbf{r}=\text { Valor residual, }[\mathrm{R} \$] \\
& \mathbf{n}=\text { Vida esperada dos equipamentos, [anos]; } \\
& \mathbf{N}=\text { Período de estudo, [anos]. }
\end{aligned}
$$

A RBC maior do que 1, indica que o projeto é viável.

\subsubsection{Hipótese e premissas da análise}

Hipótese: A Prefeitura Municipal de João Pessoa capta 100\% dos recursos necessários à implantação do projeto de melhoria da eficiência do sistema de iluminação pública, nas condições de financiamento do PROCEL.

\section{Premissas técnicas}

No estudo de caso foram adotas as seguintes premissas técnicas:

- Adequação dos niveis de iluminância produzidos pelo sistema de iluminação aos recomendados pela normas brasileiras da ABNT NBR 5101;

- Substituição das lâmpadas mistas e vapor mercúrio existentes por lâmpadas VSAP de maior eficiência;

- Instalação de reatores de alto fator de potência e substituição de todas as luminárias existentes por luminárias de alto rendimento ótico; 


\section{Premissas econômicas}

TABELA 5.2 Premissas da análise econômica.

\begin{tabular}{|c|c|}
\hline Taxa de desconto & $12 \%$ a.a. \\
\hline FRC $(12 \%, 10)$ & 0,1770 \\
\hline Tarifa média de IP & $\mathrm{R} \$ 97,00 / \mathrm{MWh}$ \\
\hline Alíquota do ICMS & $20 \%$ \\
\hline Preço da energia da IP & R\$121,25/MWh \\
\hline $\begin{array}{l}\text { Preço médio da energia } \\
\text { (outras classes) }\end{array}$ & $\mathrm{R} \$ 142,50 / \mathrm{MWh}$ \\
\hline $\begin{array}{l}\text { Preço da energia comprada pela } \\
\text { SAELPA (suprimento) }\end{array}$ & $\mathrm{R} \$ 37,00 / \mathrm{MWh}$ \\
\hline Período de análise & 10 anos \\
\hline Custo unitário evitado de energia (1) & $46,85(\mathrm{R} \$ / \mathrm{MWh})$ \\
\hline Custo unitário evitado de potência ${ }^{(2)}$ & 208,32 (R\$/kW.ano) \\
\hline \multicolumn{2}{|c|}{ Condiçōes financeiras do financiamento $^{(3)}$} \\
\hline Carência & 2 anos \\
\hline Período de amortização & 3 anos \\
\hline Juros & $\begin{array}{l}5 \% \text { a.a sobre o saldo devedor } \\
\text { corrigido }\end{array}$ \\
\hline Taxa de administração & $1 \%$ \\
\hline Correção do saldo devedor & $1 \%$ a.a. \\
\hline
\end{tabular}

(1) e (2) Fonte: ANEEL (1999).

(3) Fonte: ELETROBRÁS (1997)

- Tempo de funcionamento do sistema de IP - 4.380 horas/ano;

- Cálculo do valor residual de cada equipamento, considerando a depreciação linear ao longo do tempo de vida útil; 
- Reposição dos equipamentos ocorrendo no término da vida útil, utilizando-se a taxa efetiva de desconto;

- Receitas e despesas nos fluxos de caixa ocorrendo no final de cada ano;

- Custo total de mão de obra para a substituição/instalação do conjunto (lâmpada+luminária+reator/ignitor), distribuido para cada tipo de componente;

- Custos de mão de obra com base nos preços de mercado para a região Nordeste, e diferenciados para cada sistema, iluminação pública padronizada e especial, considerando altura dos postes, tipos de equipamento utilizados e tempo de execução do serviço;

- Impostos (ICMS e IPI) e transporte até o local de instalaçăo, inclusos nos custos de material;

- Investimento inicial para repor o sistema de IP existente considerando apenas a instalação/reposição de lâmpadas, mantendo-se, no período de estudo, as atuais luminárias e reatores.

O ANEXO IV apresenta os dados do projeto e as planilhas com o memorial dos cálculos. 


\subsection{Análise dos resultados}

TABELA 5.3 Resultados da análise econômica.

\begin{tabular}{|c|c|c|c|c|c|}
\hline & \multicolumn{4}{|c|}{ PESTHDOS } \\
\hline & & \multirow{2}{*}{ ENowh } & \multirow{2}{*}{ Exthold } & \multicolumn{2}{|c|}{ 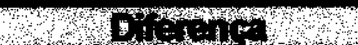 } \\
\hline & & & & (D) 10 & X \\
\hline \multirow{7}{*}{\multicolumn{2}{|c|}{$\begin{array}{l}\text { Potência Instalada (kW) } \\
\text { Energia Consumida (WWhano) } \\
\text { Gasto com Energia (R\$/ano) } \\
\text { CCV (R\$) } \\
\text { CCVA (R\$/ano) } \\
\text { CCVANE (R\$/ano) } \\
\text { Fluxo Luminoso Global (Mim) }\end{array}$}} & 2.738 & 4.828 & $(2.090)$ & $43,3 \%$ \\
\hline & & 11.991 & 21.148 & (9.157) & $43,3 \%$ \\
\hline & & 1.453 .977 & 2.564 .157 & $(1.110 .180)$ & $43,3 \%$ \\
\hline & & 4.931 .530 & 15.680 .608 & (10.749.078) & $68,6 \%$ \\
\hline & & 872.803 & 2.775 .219 & (1.902.416) & $68,6 \%$ \\
\hline & & 540.844 & 211.062 & 329.783 & $156,2 \%$ \\
\hline & & 242,22 & 214,24 & 28 & $13,1 \%$ \\
\hline \multirow{5}{*}{\multicolumn{2}{|c|}{$\begin{array}{l}\text { TRS (anos) } \\
\text { TIR } \\
\text { CEE (R\$MWh) } \\
\text { RBC }\end{array}$}} & & & & \\
\hline & & \multicolumn{4}{|c|}{2,1} \\
\hline & & \\
\hline & & & & & \\
\hline & & \multicolumn{4}{|c|}{$\begin{array}{c}36,02 \\
1,6\end{array}$} \\
\hline & & & & \\
\hline $\begin{array}{c}\text { VPL (Municipio) } \\
\text { (RS) }\end{array}$ & $\begin{array}{l}\text { chaf. } \\
\text { s/dif. }\end{array}$ & \multicolumn{2}{|c|}{1.914 .199} & \multicolumn{2}{|c|}{$\begin{array}{l}\text { TR }=5 \text { anos } \\
T R=7 \text { anos }\end{array}$} \\
\hline $\begin{array}{l}\text { Reduçắo de } \\
\text { faturamento } \\
\text { da Concessionária } \\
\text { (R\$) }\end{array}$ & $\begin{array}{l}\text { (1) } \\
\text { (2) } \\
\text { (3) }\end{array}$ & \multicolumn{4}{|c|}{$\begin{array}{c}(460.990,98) \\
(86.386,42) \\
7.264,58\end{array}$} \\
\hline
\end{tabular}

(1), (2) e (3): Resultados para concessionária quando ela vende, respectivamente, $30 \%, 70 \%$ e $80 \%$ da energia economizada a outras classes de consumidores.

Em termos gerais, os resultados das análises indicam que o projeto apresenta indicadores bastante favoráveis à sua implementação: TRS $=2,1$ anos e TIR $82 \%$. A melhoria da eficiência energética do sistema de iluminação pública objeto deste estudo, mostra ainda que poderá haver uma redução de $68,6 \%$ nos custos operacionais durante o periodo analisado, proporcionado pela economia de energia elétrica.

A seguir, analisa-se a viabilidade do projeto sob a ótica do município, concessionária, usuários locais e sociedade como um todo. 


\subsubsection{Ponto de vista do município}

A execução do projeto proporcionará ao município a melhoria da qualidade da iluminação pública pela introdução de equipamentos eficientes e de maior vida útil. Somente no primeiro ano de implantação, estima-se que os gastos com energia elétrica para iluminação pública sejam reduzidos em cerca de $43 \%$. Até o final do período de estudo, espera-se uma redução de $68,6 \%$ nos custos operacionais (energia elétrica + manutenção).

O custo da energia economizada $-\mathrm{CEE}=36,02 \mathrm{R} \$ / \mathrm{MWh}$, é bastante inferior à tarifa média de IP paga pela prefeitura municipal de João Pessoa, 97,00 R\$/MWh, o que também revela a atratividade do projeto.

O VPL do fluxo de caixa, considerando o investimento inicial e o serviço da divida do financiamento, mostra que o retorno dos investimentos se dará em 7 anos, sem considerar o custo diferencial entre os dois sistemas. Quando considera-se os custos diferencias entre os dois sistemas, o retorno se dará em 5 anos, o que significa que o projeto "se paga" até o final do periodo de amortização com as próprias economias decorrentes da redução dos custos operacionais.

\subsubsection{Ponto de vista da concessionária}

Nesta análise foi avaliada a repercussão da diminuição das vendas de energia elétrica da concessionária em decorrência da reduçăo de consumo de energia elétrica do sistema de iluminação pública eficiente, e a possibilidade de venda de parte dessa energia a outras classes ( residencial e comercial) com tarifas mais atrativas.

Pelos resultados da tabela 5.2, observa-se que houve uma redução de demanda de $2.090 \mathrm{MW}$ no sistema de elétrico da distribuidora, correspondente a um 
montante de energia evitada de 9.157 MWh/ano. Mesmo conseguindo vender parte da energia evitada a outras classes com uma tarifa $17 \%$ mais elevada do que a de IP, o balanço de compra e venda de energia elétrica da concessionária só voltaria ao patamar anterior se ela conseguisse vender cerca de $80 \%$ dessa energia.

\subsubsection{Ponto de vista dos usuários locais}

Os usuários locais serão beneficiados com a melhoria da qualidade da iluminação pública, inclusive o aumento médio de $13 \%$ no fluxo luminoso global produzido pelo sistema. Os indicadores econômicos do projeto também revelam uma adequada alocação dos recursos da TIP ou IPTU, pagos pelos contribuintes. Com a redução dos custos operacionais do sistema de iluminação pública, a prefeitura municipal poderá repartir os ganhos obtidos com os contribuintes, ou pelo menos não aumentar o valor da TIP ou outro tributo cobrado por esse serviço.

\subsubsection{Ponto de vista da sociedade}

A principal fonte de financiamento de projetos de conservação de energia elétrica e eficiência energética é proveniente dos recursos públicos da RGR, encargo pago pelos consumidores nas tarifas de energia elétrica. A análise na perspectiva da sociedade avalia os custos e benefícios diretos e indiretos das medidas de eficiência energética, para todos o pais, e verifica a eficiência da alocação dos recursos da RGR.

A relação beneficio/custo de 1,6 indica que investir em eficiência energética é uma opção viável e contribui para evitar investimentos na geração de energia elétrica e respectivos sistemas de transmissão e distribuição associados. 


\subsection{Conclusões}

Não se pode afirmar, à priori, que investimentos em projetos para eficiência energética nos usos finais proporciona benefícios para todos os atores simultaneamente. Verificou-se, pelos resultados da analise econômica, que a concessionária de energia elétrica reduz o seu faturamento com a implementação do projeto de melhoria da eficiência energética do sistema de iluminação pública, pelo menos a curto prazo.

Por outro lado, a eficiência energética pode proporcionar benefícios, tais como: desenvolvimento de novos negócios nessa área; redução da inadimplência das prefeituras municipais; diminuição das perdas técnicas do sistema elétrico; possibilidade de vender parte da energia economizada a consumidores com tarifas mais atrativas e postergar investimentos na expansão do sistema elétrico de distribuição.

Entretanto, o projeto proporciona beneficios tangiveis para os municipios, os usuários locais e para toda a sociedade. Para os municipios é possivel melhorar a qualidade da iluminação pública e amortizar o financiamento com as economias decorrentes da redução dos custos operacionais.

Os usuários locais, principais beneficiários da iluminação pública, poderăo usufruir de um melhor serviço e ter os seus encargos reduzidos. Finalmente, do ponto de vista da sociedade, todo o país poderá ser beneficiado com a postergação de investimentos em novas usinas de geração de energia elétrica e sistemas de transmissão e distribuição associados. Em decorrência, estima-se também a redução dos impactos sociais e ambientais inerentes a esses empreendimentos. 


\section{SINOPSE, CONCLUSÕES E RECOMENDAÇÕES}

\section{Da importância da iluminação pública}

A iluminação pública é um serviço essencial para os centros urbanos e como tal deve ser tratado, não só pelos municípios, responsáveis legais pela sua organização e prestação, mas por todos os atores nele envolvidos. Mostramos que a iluminação pública é de significativa importância para a segurança do tráfego noturno de veículos e de pedestres, e um vetor de integração social, na medida em que a iluminação de logradouros públicos possibilita a reunião de pessoas para o trabalho, esporte e lazer.

Analisamos também o papel a iluminação pública para criar uma identidade noturna das cidades e valorizar os monumentos, fachadas de edificações históricas e de outros pontos representativos, favorecendo o desenvolvimento sócio-econômico do município.

\section{Da organizacão e prestação dos servicos de iluminacão pública}

Os primeiros serviços de iluminação pública surgiram juntamente com a criação das primeiras empresas de eletricidade no Brasil. Embora a competência legal para prestação dos serviços de iluminação pública seja dos municípios, ainda perduram conflitos a esse respeito.

Na prática, grande parte das concessionárias além de fornecer a energia elétrica para prover esse serviço, atuam também como executoras das atividades de implantação, operação e manutenção, sendo, portanto, co-responsáveis pela sua prestação e, em muitos casos, proprietárias das instalações de iluminação pública. 
A nosso ver, a questão patrimonial é um problema que deve ser resolvido com base nos instrumentos contratuais existentes e pelo bom senso da partes, de modo que os problemas administrativos ou legais nāo venham prejudicar a população usuária da iluminação pública.

\section{Da regulamentacão dos serviços de iluminacão pública}

No que se refere ao fornecimento de energia elétrica, os serviços de iluminação pública são regulamentados pela Portaria DNAEE 158/89. Esse instrumento entretanto, tem gerado mais controvérsias do que consenso, pois alguns artigos que implicam em repercussões financeira não são claros e comportam interpretaçōes dúbias, quase sempre com desvantagem para os municipios. Conforme mostramos, esses artigos dizem respeito à aplicação das tarifas B4b e B4c, ao número de horas de funcionamento do sistema de iluminação pública e aos valores das perdas nos reatores.

A regulamentação do fornecimento de energia elétrica para iluminação pública por si só não é suficiente para resolver todos os problemas inerentes a esse serviço. Entretanto é necessário que a ANEEL edite a nova Resolução, submetida à audiência pública há mais de um ano, pois ela traz avanços significativos para mediar os principais conflitos existentes entre municípios e concessionárias.

\section{Das tarifas de iluminacão pública}

Mostramos que existem três tipos de tarifas aplicáveis ao fornecimento de energia elétrica para iluminação pública: o primeiro se refere apenas à cobrança da energia elétrica consumida (B4a); o segundo, B4b, além do consumo inclui os custos de manutenção, quando esta é prestada pela concessionária. $O$ terceiro $e$ o mais polêmico, B4c, aplicado aos sistemas de iluminação especiais que 
apresentam niveis de iluminância acima dos definidos na NBR 5101, ou que utilizam materiais diferentes dos padrões usualmente definidos pela concessionária.

Analisamos que no caso da tarifa B4c, algumas concessionárias se acham no direito de cobrar esta tarifa, que é a mais cara entre os três tipos, mesmo pela utilização de lâmpadas mais eficientes mas que produzam níveis de iluminância médios superiores aos definidos na NBR 5101.

Ora, considerando que a NBR 5101 não define limites ou niveis ou limites máximos de iluminância, excluidos os casos de comprovado exagero por excesso de potência instalada, a questão de certa forma fica em aberto. Do mesmo modo, também cobrar das prefeituras municipais uma tarifa mais elevada em função da utilizaçāo de postes, luminárias e/ou outros acessórios que não constem do padrão da concessionária, é, no mínimo, injustificável.

Assim sendo, consideramos que a proposta contida na minuta da nova Resolução da ANEEL sobre iluminação pública vem sanar tais equívocos com a extinção do referidos critérios. A tarifa B4C passaria a existir somente nos casos de instalações pertencentes aos municípios que, por conveniência das partes, forem delegados à concessionária os serviços de manutenção, inclusive seus custos. Nesse caso, a exemplo do que ocorre com a tarifa B4b, os custos com os materiais especiais já estariam incluidos.

Da cobranca dos servicos aos usuários ou das alternativas à taxa de iluminacão pública

Historicamente os municipios têm buscado alternativas para obtenção de uma fonte específica de recursos para cobertura dos custos dos serviços de iluminação pública. A maneira tradicionalmente adotada no Brasil tem sido a TIP - Taxa de 
lluminação Pública, cobrada aos consumidores de energia elétrica e aos proprietários de terrenos urbanos. A cobrança da TIP é considerada ilegal, embora alguns municípios ainda consigam mantê-la.

Os projetos que criam alternativas para o custeio dos serviços de iluminação pública em tramitação no Congresso Nacional, parecem já comportar vícios de incostittucionalidade, ou infringir os princípios e normas do direito tributário. Por outro lado, não acreditamos que haja possibilidades legais desses serviços serem cobrados como taxa. É possivel que seja aprovada uma dessas leis mas, provavelmente, também sofrerá contestações jurídicas. Parece-nos que uma alternativa seria a criaçāo de um imposto específico, o que a princípio, não parece ser politicamente fácil.

Das oportunidades e barreiras para promocão da eficiência energética na iluminação pública

Mostramos, numa revisão histórica e conceitual, que existe farta literatura internacional que identifica as barreiras e oportunidades para a conservação de energia elétrica e a eficiência energética, e que aponta como principais benefícios da conservação de energia, a redução dos impactos sociais e ambientais para toda a sociedade.

Entretanto, quantificar esses beneficios parece não ser somente uma limitação deste trabalho, pois, particularmente no Brasil, ainda não existe consenso sobre que metodologias seriam aplicadas para tal. Entendemos que embora hajam elementos preliminares para inferir os benefícios sócio-ambientais, a questão deve ser aprofundada. A obtenção de resultados mais tangiveis certamente ajudariam a convencer e esclarecer os atores da eficiência energética, os formuladores de políticas e os tomadores de decisão, da importância de conciliar as necessidades energéticas com o desenvolvimento sustentável. 
No tocante ao financiamento da eficiência energética, no caso da iluminação pública, consideramos que as restriçōes para financiamento direto aos municípios pelo PROCEL é uma das principais barreiras. Isso poderia ser resolvido com a regulamentação do artigo da lei que criou a ANEEL, que autorizou essa possibilidade. No entanto esse dispositivo precisa ser regulamentado.

Mais preocupante ainda é a extinção da própria fonte de financiamento do PROCEL - a RGR. Portanto, entendemos ser necessário desde já provocar a discussão de alternativas à RGR, e criar as condições favoráveis para que o mercado também possa prover o financiamento da eficiência energética no Brasil.

Dos resultados das análises econômicas do projeto de melhoria da eficiência energética com o estudo de caso de João Pessoa - PB

Os resultados das análises econômicas no caso de João Pessoa, revelam que o município é o principal beneficiado com o projeto de melhoria da eficiência energética do sistema de iluminação pública. A instalação de lâmpadas VSAP, luminárias e reatores eficientes, em substituição aos equipamentos obsoletos, proporciona uma iluminação de melhor qualidade e de acordo com os critérios definidos na NBR 5101.

Do ponto de vista financeiro, o municipio poderá amortizar os investimentos no sistema eficiente com as próprias economias geradas pela redução do consumo de energia elétrica. De forma semelhante, os usuários dos serviços terão uma iluminação pública de melhor qualidade e de acordo com as normas técnicas, o que terá reflexos positivos para o bem-estar da população. Também poderão ter os seus encargos reduzidos, se a prefeitura municipal repartir parte dos benefícios proporcionados pelo projeto. 
A distribuidora de energia elétrica, a princípio, diminui o seu faturamento com a venda de energia elétrica para iluminação pública, em virtude da redução de potência no sistema de iluminação pública. Entretanto essa perda de receita deve ser analisada em outras situações de contingência, especialmente no caso da necessidade de redução da demanda máxima no curto prazo.

Ações de conservação de energia elétrica com ênfase na eficiência energética nos usos finais, têm sido uma das formas de atender a demanda máxima do sistema no horário de ponta. Isso se justifica pela viabilidade econômica e menor tempo de execução em relação às opções de ampliação da capacidade ou expansão do sistema elétrico.

Do ponto de vista da sociedade os resultados săo favoráveis, pois os custos de investimento no projeto de eficiência energética são cerca de $60 \%$ mais baixos do que os custos de expandir o sistema elétrico para gerar a energia equivalente ao montante economizado.

\section{Das limitacões deste trabalho}

Pensamos que seria importante investigar até que ponto os custos dos serviços de iluminação pública oneram o orçamento municipal, e se de fato a questão da TIP é ou não o principal problema dos municípios com relação aos serviços de iluminação pública, o que não nos foi possivel pelas limitações deste trabalho.

Outra limitação diz respeito à análise da aplicação da Portaria DNAEE 730/93. Esse instrumento foi editado para compensar os possiveis casos de perda de receitas das concessionárias, eliminando mais uma importante barreira para eficiência energética. Conforme ressaltamos nas conclusões do capítulo 4 , não há registros de que as concessionárias tenham posto em prática esse mecanismo. 
Também não se pode afirmar quais as repercussões financeiras de sua aplicação no custo do serviço ou nos resultados financeiros das concessionárias.

Finalmente, com base no que apresentamos ao longo deste trabalho, concluímos que as medidas para eficiência energética e a gestão adequada dos sistemas de iluminação pública podem proporcionar beneficios para os atores envolvidos, sobretudo para a sociedade.

Por tudo que foi exposto, entendemos que deveria haver uma maior participação dos agentes públicos e privados no financiamento de projetos de eficiência energética e de estímulo ao uso racional da energia elétrica nos sistemas de iluminação pública, e que a legislação fosse revista e aperfeiçoada para tornar mais eficazes os incentivos que se pretendem conceder. 
ANEXOS 
ANEXO I PORTARIA DNAEE No $158 / 89$

O Diretor-Geral do Departamento Nacional de Águas e Energia Elétrica - DNAEE, no uso de suas atribuiçōes, $e$

Considerando as disposiçōes dos arts. $2^{\circ}$ e $3^{\circ}$ da Portaria MME $n^{\circ} 1.760$, de 16 de dezembro de 1986;

Considerando a necessidade de regulamentar e uniformizar o fornecimento de energia elétrica para iluminação pública e de aprimorar as normas e padrōes a ele aplicados;

Considerando a necessidade da estruturação de tarifas de forma a estimular a conservação de energia nessa classe, cujo consumo tem participação efetiva no horário de máxima demanda do sistema elétrico nacional;

Considerando as normas técnicas da Associação Brasileira de Normas Técnicas ABNT, e

Considerando que a Constituição Federal, no Capítulo IV, art. 30, inciso V, define ser da competência do Município a organização e a prestação do serviço de iluminação pública,

RESOLVE:

Art. $1^{\circ}$ Ficam estabelecidos, na forma que se segue, as condiçóes gerais a serem observadas no fomecimento de energia elétrica destinado a iluminação pública.

\section{DA CONCEITUAÇÃO DO SERVIÇO DE ILUMINAÇÃO PÚBLICA}

Art. $2^{\circ}$ lluminação Pública é o serviço que tem por escopo prover de luz ou claridade artificial, no periodo notumo ou nos escurecimentos diurnos ocasionais, os logradouros públicos.

\section{DA CLASSIFICAÇÃO E PADRONIZAÇÃO}

Art. $3^{\circ}$ Classificar-se-á como lluminação Pública o fornecimento de energia elétrica para iluminação de ruas, praças, avenidas, jardins, vias, estradas e outros logradouros de domínio público, de uso comum e livre acesso, de responsabilidade de pessoa jurídica de direito público, devendo ser consideradas as seguintes categorias:

a) Iluminação Pública Padronizada;

lluminação Pública cujas instalações observem as normas e padrões do concessionário e que estejam em consonância com os niveis de iluminância e padrōes definidos nas normas da Associação Brasileira de Normas Técnicas - ABNT.

b) Iluminação Pública Especial

lluminação Pública cujas instalaçōes não estejam compativeis com os padrōes do concessionário e/ou que excedam os niveis de iluminância definidos nas normas citadas na alínea "a" deste artigo. 


\section{DO PONTO DE ENTREGA}

Art. $4^{\circ} \mathrm{O}$ ponto de entrega da energia elétrica no atendimento dos serviços de lluminação Pública, será alternativamente:

a) a conexäo da

elétricas de lluminação Pública quando distribuiço do concessionário com as instalações

b) o bulbo da lâmpada, quando as intas pertencerem a Prefeitura Municipal, ou

pertencerem ao concessionário.

Parágrafo único. Quando

entrega será obrigatoriamente tratar de iluminação pública especial, o ponto de instalações elétricas da iluminação pública.

\section{DO INVESTIMENTO}

Art. $5^{\circ}$ Os concessionários participarão, até o ponto de entrega, dos investimentos feitos para atender o serviço de iluminação pública, nos limites por eles calculados, de
acordo com critérios definidos pelo DNAEE.

Parágrafo único $A$ us palo DNAE. iluminação pública padronizada, definidananceira do concessionário fica restrita a

\section{DOS CRITÉRIOS PARA DETERMINAÇÃO DO}

observância do disposto mensal, para fins de faturamento, será calculado com de 22 de dezembro de 1987.

\section{DOS SERVIÇOS DE OPERAÇÃo E MANUTENÇÃO}

Art. $7^{\circ} \mathrm{A}$ responsabilidade dos serviços de operação e manutenção das instalações de iluminação pública será da Prefeitura Municipal, quando o ponão das entrega se situar na conexão da rede de distribuição do concessionário ponto de $\S 1^{\circ} \mathrm{O}$ concessionário poçáo pública. artigo, mediante a celebração derá efetuar os serviços de que trata o "caput" deste Prefeitura Municipal, responsável contrato específico para tal fim, ficando, todavia, a

$\S 2^{\circ}$ Quando o ponto de lespesas dele decorrentes.

responsabilidade pelos serviços entrega se situar no bulbo da lâmpada, a concessionário.

\section{DOS CONTRATOS}

Art. $8^{\circ}$ Os contratos a serem firmados pelos concessionários com as Prefeituras Municipais terão a finalidade de ajustar a prestação de serviços de iluminação pública, manutenção das instalaçōes. deverá conter, além das cláusula, respeitada a particularidade de cada modalidade, digam respeito a:

a) autorização legislativa; 
b) propriedade das instalações;

c) ponto de entrega;

d) forma e condições para prestação de serviços;

e) tarifas e tributos aplicáveis;

f) faturamento.

\section{DAS TARIFAS}

Art. $9^{\circ}$ As tarifas aplicáveis aos fomecimentos de energia elétrica para iluminação pública serão estruturadas de acordo com a localização do ponto de entrega e nivel de
iluminância, a saber:

I - tarifa B4: aplicável quando o ponto de entrega for a conexão do sistema de
distribuição do concessionário com as instalaçōes de iluminação pública

II - tarifa B4b: aplicável quando o ponto deçes de iluminação pública;

III - tarifa B4c: aplicável a fornecimentos entrega for o bulbo da lâmpada;

pública especial que excedam aos niveis de realizados a instalaçōes de iluminação do art. $3^{\circ}$ de iluminação uública instalados a partir da vigência desta Pontos realizados a sistema

Art. 10. As omissōes, dúvidas e resolvidos e decididos pelo DNAEE.

Art 11. O concessiona DAEE. aos critérios, procedimentos e estrutura de tarifas orientar a Prefeitura Municipal quanto

Art. 12. Esta Portaria entra em vigor tarifas regulamentadas nesta Portaria. disposições em contrário. 


\title{
ANEXO II MINUTA DE REVISÃO DA PORTARIA DNAEE NN 158/89
}

\author{
AGÊNCIA NACIONAL DE ENERGIA ELÉTRICA \\ RESOLUÇÃO No , DE DE 1999.
}

Estabelece as Condiçöes Gerais de Fomecimento de Energia Elétrica para lluminação pública.

O DIRETOR-GERAL DA AGÊNCIA NACIONAL DE ENERGIA ELÉTRICA - ANEEL, no
uso de suas atribuições regimentais, de acordo com Deliberaçăo da Diretoria, e considerando a necessidade de rever, atualizar e consolidar as disposiçōes referentes às Condiçöes Gerais de Fornecimento de Energia Elétrica destinada à lluminaçăo Pública e adequá-las às leis $n^{\circ} 8.078$, de 11 de setembro de 1990 - Código de Defesa do Consumidor, 8.631, de 4 de março de 1993 - Desequalização Tarifária do Setor Elétrico, 8.987, de 13 de fevereiro de 1995 - Normas para Outorga e Prorrogaçōes de Concessōes, 9.427, de 26 de dezembro de 1996 - Institui a Agência Nacional de Energia Elétrica e 9.648, de 27 de maio de 1998 - Reestruturação da Eletrobrás,

\section{RESOLVE:}

Art. $1^{\circ}$ Estabelecer as condiçōes gerais de fornecimento de energia elétrica destinada à iluminação pủblica.

\section{DA CONCEITUAÇÃO DO SERVIÇO DE ILUMINAÇÃO PÚBLICA}

Art. $2^{\circ}$ lluminação Pública é o serviço que tem por escopo prover de luz ou claridade artificial, no período noturno ou nos escurecimentos diumos ocasionais, os

Parágrafo único. Inclui-se neste conceito os logradouros públicos que necessitam de iluminação permanente do período diumo.

\section{DA CLASSIFICAÇÃO}

Art. $3^{\circ}$ Classificar-se-á como lluminação Pública o fomecimento de energia elétrica para iluminação de ruas, praças, avenidas, túneis, passagens subterrâneas, jardins, vias, estradas, passarelas, abrigos de usuários de transportes coletivos, e outros logradouros de domínio público, de uso comum e livre acesso, cuja responsabilidade pelo pagamento das contas e pelas demais obrigações legais, 
regulamentares e contratuais seja assumida, exclusivamente, por pessoa jurídica de direito público.

\$1 Classifica-se também como lluminação Pública, o fornecimento de energia elétrica destinada à iluminação de monumentos, fachadas e obras de arte de valor histórico cultural ou ambiental localizadas em áreas públicas e fontes luminosas. Para caracterização do valor histórico cultural ou ambiental do patrimônio devem ser atendidos os critérios estabelecidos no decreto-lei $n^{\circ} 25$, de 30 de novembro de 1937 , e demais disposições previstas nas legislações federal, estadual e municipal.

$\S 2^{\circ} \mathrm{O}$ caput deste artigo e $\circ \S 1^{\circ}$ não se aplicam quando a energia elétrica se destinar à iluminação para fins de propaganda, publicidade e marketing.

\section{DO PONTO DE ENTREGA}

Art. $4^{\circ}$ O ponto de entrega da energia elétrica no atendimento dos serviços de lluminação Pública, será alternativamente:

1) a conexão da rede de distribuição do concessionário com as instalações elétricas de lluminação Pública, quando estas pertencerem ao Municipio, ou

II) o bulbo da lâmpada, quando, havendo interesse entre as partes, as instalações destinada à lluminação Pública pertencerem ao concessionário.

\section{DO INVESTIMENTO}

Art. $5^{\circ}$ As obras necessárias ao atendimento de aumento ou ligação de novas cargas de lluminação Pública, serão custeadas pelo Municipio e pelo concessionário, de acordo com os critérios estabelecidos na legislação especifica sobre participação

\section{DOS CRITÉRIOS DE FATURAMENTO}

Art. $6^{\circ}$ Sempre que viável técnica e economicamente, o consumo de energia elétrica mensal, para fins de faturamento, deverá ser aquele registrado pelos equipamentos de medição instalados pelo concessionário.

Art. $7^{\circ}$ Nos caos em que não for viável técnica e economicamente a instalação de equipamentos de medição, o consumo mensal de energia elétrica para fins de faturamento será calculado com base na carga instalada, incluída a carga dos equipamentos auxiliares, de acordo com o art. 58 e seu parágrafo único, da Portaria DNAEE n 466, de 12 de novembro de 1997.

$\$ 1^{\circ}$ Fica facultado ao concessionário e ao Poder Püblico Municipal negociar o número de horas mensais para fins de faturamento quando, através de estudos realizados pelas partes ou por terceiros contratados com a finalidade de se determinar - número efetivo de horas de utilização do sistema de lluminação Pública, for constatado um número de horas diferente do estabelecido no parágrafo único do art. 58 da Portaria DNAEE $n^{\circ}$ 466, de 12 de novembro de 1997. 
$\$ 2^{\circ}$ Caso sejam instalados equipamentos automáticos de controle de carga que comprovadamente reduzam o consumo de energia elétrica do sistema de lluminação Pública, o concessionário deverá proceder à revisão da estimativa de consumo, levando em conta a redução proporcionada por tais equipamentos.

$\S 3^{\circ}$ O cálculo da energia consumida pelos equipamentos auxiliares de lluminação Pública, previsto no artigo 58 da Portaria DNAEE $n^{\circ} 466$, de 12 de novembro de 1997, deverá ser baseado em critérios das normas da ABNT, em dados do fabricante dos equipamentos, ou em ensaios feitos em laboratórios credenciados, devendo as condiçōes pactuadas constarem do contrato de fornecimento de energia elétrica.

\section{DOS SERVIÇOS DE ILUMINAÇÃO PÚBLICA}

Art. $8^{\circ}$ A responsabilidade dos serviços de projeto, implantação, operação e manutenção das instalações de iluminação pública é do Municipio.

$\$ 1^{\circ}$ O concessionário poderá efetuar os serviços de que trata o caput deste artigo, mediante a celebração de contrato ou convênio específico para tal fim, ficando, todavia, o Poder Público Municipal, responsável pelas despesas deles decorrentes.

§2 ${ }^{\circ}$ Quando o ponto de entrega se situar no bulbo da lâmpada, a responsabilidade pelos serviços de operação e manutençāo, inclusive seus custos, é do concessionário e os serviços de projeto implantação e expansão da rede serão executados de acordo com o $\$ 1^{\circ}$ deste artigo. Neste caso, as novas instalaçōes deverão utilizar materiais em uso pelo concessionário, podendo haver negociação entre as partes para aplicação de materiais e/ou equipamentos diferentes.

Art. $9^{\circ}$ O Contrato de Fornecimento de Energia Elétrica para fins de lluminação Pública deverá conter, além das cláusulas essenciais aos contratos administrativos, outras que digam respeito a:

- tensão de fornecimento;

- propriedade das instalações;

- forma e condições para prestação dos serviços;

- procedimentos para alteração de carga e atualização do cadastro;

- tarifas e tributos aplicáveis:

- condições de faturamento, incluindo critérios para contemplar falhas no funcionamento do sistema tais como: falta de energia, lâmpadas apagadas, e lâmpadas acesas durante 0 dia;

- condiçōes de faturamento das perdas conforme $\$ 3^{\circ}$ do artigo $7^{\circ}$.

- condições e procedimentos para o uso de postes e da rede de distribuição;

- datas para leitura dos medidores, quando for o caso, apresentação e vencimento das contas.

\section{DAS TARIFAS}

Art. $10^{\circ}$ As tarifas aplicáveis aos fomecimentos de energia elétrica para iluminação pública seräo estruturadas de acordo com a localização do ponto de entrega, a saber: 
I - tarifa B4a: aplicável quando o ponto de entrega for a conexāo do sistema de distribuição do concessionário com as instalações de iluminação pública; II - tarifa B4b: aplicável quando o ponto de entrega for o bulbo da lâmpada;

III - tarifa B4c: aplicável quando o ponto de entrega for o bulbo da lâmpada e tratar-se de fornecimentos que utilizam, por interesse do Poder Público Municipal, materiais diferentes dos tipicamente empregados pelo concessionário nas instalaçōes de lluminação Pública de sua propriedade.

Art. 11 As omissões, dúvidas e casos não previstos nesta Resolução serão resolvidos e decididos pela ANEEL.

Art. 12 O concessionário deverá informar e orientar ao Poder Público Municipal quanto aos critérios, procedimentos e tarifas aplicáveis ao fornecimento de energia elétrica destinada à lluminação Pública.

Art. 13 Esta Resolução entra em vigor no dia , revogadas as disposições em contrário. 


\section{ANEXO III PORTARIA DNAEE N ${ }^{\circ} \mathbf{7 3 0 / 9 3}$}

O Diretor-Adjunto do Departamento Nacional de Águas e Energia Elétrica DNAEE, no uso da atribuição estabelecida pelo inciso II do art. 123, combinada com aquela definida pelo inciso VI do art. 122, ambos do Regimento Interno da Secretaria de Energia, aprovado pela Portaria do Ministro de Minas e Energia - MME $n^{\circ} 65$, de 11 de fevereiro de 1993 , tendo em vista o disposto no art. 10 e no art. 27 do Decreto $n^{\circ}$ 41.019, de 26 de fevereiro de 1957, e

Considerando que o uso e a oferta eficientes de energia elétrica são fundamentais para a redução dos custos do serviço público de energia elétrica;

Considerando os esforços empreendidos pelo governo federal, supervisionados pelo Grupo Coordenador de Conservação de Energia Elétrica - GCCE, e operacionalizados pelo Programa Nacional de Conservação de Energia Elétrica PROCEL;

Considerando que são justificáveis regras que propiciem o melhor aproveitamento dos recursos energéticos, dentro do processo de otimização global da economia; e

Considerando ser conveniente o estabelecimento de regras específicas para o registro de gastos dos concessionários do serviço público de energia elétrica, no desenvolvimento de programas de eficiência energética,

RESOLVE:

Art. $1^{\circ}$ Serão computáveis respectivamente no Custo do Serviço ou no Investimento Remunerável dos concessionários do serviço público de energia elétrica, os gastos com o custeio e investimentos relativos a programas de incremento da eficiência no uso e na oferta de energia elétrica.

$\S 1^{\circ}$ Os gastos de que trata o caput deste artigo deverão ser submetidos à aprovação deste Departamento, que considerará, em sua decisão, parecer do PROCEL sobre o objetivo e o desempenho do respectivo programa.

$\S 2^{\circ}$ Os gastos de custeio e investimentos, aprovados conforme o disposto no $\S$ $1^{\circ}$, serão contabilizados em registro suplementar de controle analítico do concessionário e de acordo com o Plano de Contas do Serviço Público de Energia Elétrica.

Art. $2^{\circ}$ Os programas que tiverem evidente potencial de contribuição para a formaçảo de mais de um resultado de exercícios sociais futuros, terăo os respectivos gastos contabilizados no Ativo Diferido, através do Sistema de Ordens em Curso ODS, e serão aceitos no Custo do Serviço por amortização, na medida e proporção em que sua contribuição influencie a geração de resultados em cada exercício.

Art. $3^{\circ}$ Esta Portaria entra em vigor na data de sua publicação. 


\section{ANEXO IV Estudo de caso: memorial e planilha de cálculos}

Projeto de melhoria da efíciência energética do sistema de iluminação pública de João Pessoa - PB.

\section{1 - DADOS DO PROJETO}

\section{1 - Parâmetros Técnicos}

\begin{tabular}{|c|c|c|c|c|c|c|c|c|c|}
\hline \\
\hline \multirow{2}{*}{$\begin{array}{l}\text { Tipo de } \\
\text { lâmpada }\end{array}$} & \multirow{2}{*}{$\begin{array}{c}\text { Poténcia } \\
\text { [lâmp.+reator] }^{*} \\
\text { (W) }\end{array}$} & \multirow{2}{*}{$\begin{array}{l}\text { Quant } \\
\text { (UN) }\end{array}$} & \multirow{2}{*}{$\begin{array}{l}\text { Potencia } \\
\text { total } \\
\text { (kw) }\end{array}$} & \multirow{2}{*}{$\begin{array}{c}\text { Energid } \\
\text { consumida } \\
\text { (wWh) }\end{array}$} & \multirow{2}{*}{$\begin{array}{c}\text { Fluxo } \\
\text { unitário } \\
(\mathrm{lm})\end{array}$} & \multirow{2}{*}{$\begin{array}{l}\text { Fuxo } \\
\text { cotal } \\
\text { (1nim) }\end{array}$} & \multicolumn{3}{|c|}{ Vida Util (h) } \\
\hline & & & & & & & Lâmpada & $\begin{array}{l}\text { Reator } \\
\text { lgnitor }\end{array}$ & Luminária \\
\hline M1EDW & 160 & 1250 & 200 & 876 & 3.100 & 3,88 & 8.000 & - & 65.700 \\
\hline $\mathbf{M 2 5 0}$ & 250 & 2250 & 562,5 & 2463,75 & 5.600 & 12,60 & 8.000 & 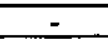 & 65.700 \\
\hline $\mathrm{Mm} 80 \mathrm{~W}$ & 00 & 6.040 & 537,56 & 2354,5128 & 3.500 & 21,14 & 12.000 & 43.800 & 65.700 \\
\hline VM250W & 4 & 570 & 978,18 & 4284,4284 & 12.500 & 44,63 & 12.000 & 43.800 & 65.700 \\
\hline VM $400 \mathrm{~W}$ & 425 & 10 & 2550 & 11169 & 22.000 & 932,00 & 12.000 & 43.800 & 65.700 \\
\hline \multicolumn{2}{|l|}{ TOTAL } & 9.110 & 4828,24 & 21147,6912 & 20. & 214,24 & & & \\
\hline \multicolumn{10}{|c|}{ 2-Sistema Eliciente (Propossto) } \\
\hline VSAP $70 W$ & 85 & 540 & 811 & $3.551,74$ & 6.000 & 57,24 & 24.000 & 43.800 & 65.700 \\
\hline VSA & 170 & 0 & 607 & $2.658,22$ & 14.000 & 49,98 & 24.000 & 43.800 & 65.700 \\
\hline \multirow[t]{2}{*}{$\mathbf{W}$} & 440 & $\overline{00}$ & 1320 & $5.781,60$ & 45.000 & 135 & 24.000 & 43.800 & 87.600 \\
\hline & $m$ & 16.110 & 2.738 & $11.81,6$ & & 242,22 & & &  \\
\hline
\end{tabular}

M = Mista; VM - Vapor de Mercúrio; VSAP = Vapor de Sódio Alta Pressão.

* Valores de perdas nos reatores

\begin{tabular}{|c|c|}
\hline Tipo de lámpada & Perdas no reator $(W)$ \\
\hline VM 250 W & 24 \\
\hline VM 400 W & 25 \\
\hline VSAP 70 W & 15 \\
\hline VSAP 150 W & 20 \\
\hline VSAP 400 W & 40 \\
\hline
\end{tabular}

Fonte: PROCEL, 1998.

1.2 - Potência instalada, consumo e gasto com energia elétrica

\begin{tabular}{|c|c|c|c|c|}
\hline Item & $\begin{array}{c}\text { Sistema a ser } \\
\text { substituido } \\
\text { (EC) }\end{array}$ & $\begin{array}{c}\text { Sistema } \\
\text { Eficiente } \\
\text { (EE) }\end{array}$ & Diferença & (\%) \\
\hline Potência (kW) & 4.828 & 2.738 & 2.090 & 43 \\
\hline Energia (MWh) & $21.147,69$ & $11.991,60$ & 9.156 & 43 \\
\hline Gasto com energia $(\mathrm{R} \$)^{\star}$ & $2.564 .157,56$ & $1.453 .977,14$ & $1.110 .180,4$ & 43 \\
\hline
\end{tabular}

* Gasto c/ energia elétrica $(\mathrm{R} \$)=$ Energia (MWh) $\times$ Tarifa c/ ICMS (R\$/MWh). 


\section{2 - CUSTOS E ORÇAMENTO (R\$)}

\section{1 - Sistema Existente (a ser substituído)}

2.1.1 - Material e mão-de-obra ( $R \$)$

\begin{tabular}{|c|c|c|c|c|c|c|c|}
\hline \multirow{2}{*}{\multicolumn{8}{|c|}{ I.AMPADAS }} \\
\hline MISTA 1CW & 1.250 & 8,00 & $10.000,00$ & 3,75 & & $1.000,00$ & \\
\hline MISTA 250 W & 2250 & 10,00 & $22.500,00$ & 3,75 & $\frac{4.687,50}{8.437,50}$ & $\frac{1.000,00}{2250,00}$ & $\frac{15.687,50}{33.187,50}$ \\
\hline VM $30 \mathrm{w}$ & 6.040 & 870 & $52.548,00$ & 4,25 & $\frac{8.437,50}{25.670,00}$ & $\frac{2250,00}{5.254,80}$ & $\frac{33.187,50}{83.47280}$ \\
\hline VM 25N & 3.570 & 15,00 & $53.550,00$ & 8,50 & $\frac{25.670,00}{30.345,00}$ & $\frac{5.254,80}{5.355,00}$ & $83.472,80$ \\
\hline VM 400 & 6.000 & 25,00 & $150.000,00$ & 10,00 & $\frac{30.345,00}{60.000,00}$ & $\frac{5.355,00}{15.000,00}$ & $89.250,00$ \\
\hline s-btal & 19.110 & & $2+5 x+3$ & & $\frac{60.000,00}{129.14064}$ & $\frac{15.000,00}{28.859,84}$ & $225,000,00$ \\
\hline \multirow{2}{*}{\multicolumn{8}{|c|}{$\frac{\text { StAWA }}{\text { REATORES/IGNITORES }}$}} \\
\hline VM & $\overline{0}$ & 0,00 & 0,00 & 3.75 & & & \\
\hline VM 250 W & 0 & 0,00 & 0,00 & 3,75 & $\frac{0,00}{0,00}$ & $\frac{0,00}{0,00}$ & 0,00 \\
\hline VM 400 & $\overline{0}$ & 0,00 & 0,00 & 10,00 & $\frac{0,00}{0,00}$ & 0,00 & 0,00 \\
\hline Subtotal & 0 & 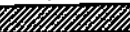 & 0,00 & 1119 & $\begin{array}{l}0,00 \\
0,00\end{array}$ & 0,00 & 0,00 \\
\hline \multirow{2}{*}{\multicolumn{8}{|c|}{$\begin{array}{l}\text { Subtotal } \\
\text { LUNAINARIAS }\end{array}$}} \\
\hline MISTA 10w & $\overline{0}$ & 0,00 & 0,00 & 7,50 & & & \\
\hline MISTA 250 $\mathrm{w}$ & $\overline{0}$ & 0,00 & $\frac{0,00}{0,00}$ & $\frac{1,20}{7,50}$ & $\frac{0,00}{0,00}$ & $\frac{0,00}{0,0}$ & 0,00 \\
\hline VM $\mathbf{~} \mathbf{w}$ & 0 & 0,00 & 0,00 & 8,50 & $\frac{0,00}{0,00}$ & 0,00 & 0,00 \\
\hline VM 250W & 0 & 0,00 & 0,00 & 8,50 & $\frac{0,00}{0,00}$ & 0,00 & 0,00 \\
\hline VM $400 \mathrm{w}$ & 0 & 0,00 & 0,00 & 20,00 & $\begin{array}{l}0,00 \\
0,00\end{array}$ & 0,00 & 0,00 \\
\hline Sabtotal & 0 & & 0,00 & & $\frac{0,00}{0,00}$ & 0,00 & 0,00 \\
\hline Tetal Geral & & & $2 \mathrm{i} 5 \mathrm{sg}, 0$ & & $\frac{0,00}{129.140,00}$ & $\frac{0,00}{23.8598}$ & 0,00 \\
\hline & & & & & 123.14690 & 23,5528 & 46597.0 \\
\hline
\end{tabular}

Nota:

Custo de mão-de-obra

\begin{tabular}{|l|c|}
\hline \multicolumn{1}{|c|}{ Item } & Custo (RS) \\
\hline Sistema padronizado (1) & 20,00 \\
\hline Sistema especial (2) & 40,00 \\
\hline
\end{tabular}

* Custo de măo-de-obra para instajaçáo/retirada do conjunto: luminária, lâmpada e reator. No caso da retirada/instalaçăo somente da lámpada, considerou-se os custos proporcionais com base nos preços de mercado.

(1) O sistema padronizado compreende as lâmpadas mistas e vapor mercúrio até $250 \mathrm{~W}$ instaladas em braços de até 3,0 metros e postes de até 10 metros de altura de montagem.

(2) O sistema especial compreende as lâmpadas VM 400W instaladas em topo de poste de mais de 12 metros de altura de montagem.

\subsection{2 - Resumo do Orçamento Global}

\begin{tabular}{|l|r|}
\hline \multicolumn{1}{|c|}{ Item } & Custo (R\$) \\
\hline Material & $288.598,00$ \\
\hline Mão-de-obra & $129.140,00$ \\
\hline Eng $^{\text {a }}$ e Supervisão & $28.859,80$ \\
\hline IC $^{*}$ & $446.597,80$ \\
\hline
\end{tabular}

${ }^{*} \mathrm{IC}=$ Investimento inicial no sistema existente. 
2.2 - Sistema Proposto (Eficiente)

2.2.1- Material e mão-de-obra (R\$)

\begin{tabular}{|c|c|c|c|c|c|c|c|}
\hline \multirow{2}{*}{\multicolumn{7}{|c|}{ LAMPADAS }} & \\
\hline 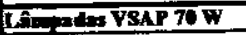 & 9.540 & 12,00 & $114,480,00$ & 5,00 & $47.700,00$ & $11.448,00$ & \\
\hline In & 3.570 & 17,00 & $60.690,00$ & 5,00 & $17.850,00$ & & $173.628,00$ \\
\hline LA adn: VSAP 4SN w & 3.000 & 30,00 & $90.000,00$ & 10,00 & $30.000,00$ & $\frac{6.069,00}{9.000,00}$ & $84.609,00$ \\
\hline Subtotal & 16.110 & & $265,17,6$ & & $95.550,0$ & $\frac{9.000,00}{26.517,00}$ & $129.000,00$ \\
\hline \multirow{2}{*}{\multicolumn{8}{|c|}{$\begin{array}{c}\text { Snhtotal } \\
\text { REATORES / IGNITORES }\end{array}$}} \\
\hline VSAP70W & 9.540 & 25,00 & $238,500,00$ & 5,00 & $47.700,00$ & & \\
\hline VSAP IS0 W & 3.570 & 38,00 & $135.660,00$ & 5,00 & $\frac{47.700,00}{17.850,00}$ & $23.850,00$ & $310.050,00$ \\
\hline VSAP $400 \mathrm{~W}$ & 3.000 & 43,00 & $129.000,00$ & 10,00 & $\frac{17.850,00}{30.000,00}$ & $13.566,00$ & $167.076,00$ \\
\hline Subtotal & 16.110 & & sen,16en & & $\frac{30.000,00}{95.550,00}$ & $12.900,00$ & $171.900,00$ \\
\hline \multirow{2}{*}{\multicolumn{8}{|c|}{\begin{tabular}{|l} 
Sabtotal \\
LUMINARIAS \\
\end{tabular}}} \\
\hline VSAP 70W & 9.540 & 42,00 & $400,680,00$ & 10,00 & $95.400,00$ & & \\
\hline VSAP $150 \mathrm{~W}$ & $3 . \overline{570}$ & 91,00 & $324.870,00$ & 10,00 & $\frac{95.400,00}{35.700,00}$ & $40.068,00$ & $536.148,00$ \\
\hline VSAP $400 \mathrm{~W}$ & 3.000 & 225,00 & $675,000,00$ & 20,00 & $\begin{array}{l}35.700,00 \\
60.000,00\end{array}$ & $32.487,00$ & $393.057,00$ \\
\hline Sobtotal & 16.110 & & $1.41556,10$ & & $191.10,40$ & $\frac{67.500,00}{140.055,00}$ & $802.500,00$ \\
\hline Totil Getal & & & $2.168 .800,00$ & & 392.200 .99 & $\frac{140.055,00}{216.588,00}$ & $1.731 .705,0 \%$ \\
\hline
\end{tabular}

\subsection{2 - Resumo do Orçamento Global}

\begin{tabular}{|l|r|}
\hline \multicolumn{1}{|c|}{ Item } & \multicolumn{1}{c|}{ Custo (RS } \\
\hline Material & $2.168 .880,00$ \\
\hline Mão-de-obra & $382.200,00$ \\
\hline Enga e Supervisão & $216.888,00$ \\
\hline IE $^{\star}$ & $2.767 .968,00$ \\
\hline
\end{tabular}

${ }^{*} \mathrm{IE}=$ Investimento inicial no sistema eficiente:

2.2.3 - Cálculo do TRS (Conforme equação 5.1)

$$
\text { TRS }=\frac{(2.767 .968,00)-(446.597,80)}{121,25(21.147,69-11.991,60)}
$$

TRS $=2,1$ anos 
3 - Cálculos do CVV, CCVA e CEE de acordo com as equação 5.2, 5.3 e 5.4.

\begin{tabular}{|c|c|c|c|c|c|c|c|c|}
\hline \multirow{2}{*}{ 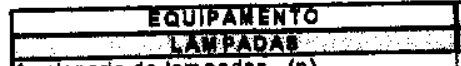 } & \multicolumn{5}{|c|}{$\begin{array}{l}\text { EXISTENTE } \\
\text { Fry }\end{array}$} & \multicolumn{3}{|c|}{ 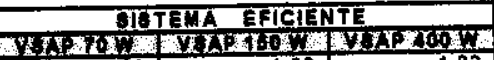 } \\
\hline & & 5,48 & 3,85 & 85 & $\frac{5.65}{3.65}$ & 1.83 & $\begin{array}{r}1,83 \\
100\end{array}$ & 1,83 \\
\hline fraclonario de lampans - (n) & & s. & 2 & & & & & \\
\hline & & $\begin{array}{r}1.83 \\
23.00 \%\end{array}$ & $\begin{array}{r}2,74 \\
36,41 \%\end{array}$ & & & & 86.0 & 88, \\
\hline (r) & 6 & 0,38 & 0.80 & & & & & ]. \\
\hline$F_{2}$ & 6.23 $3(-3)-3$ & $17.423,44$ & 28.2 & & & 10 & & \\
\hline 101 & 0 & 5 & $\begin{array}{r}2.3 \\
18130\end{array}-1-10$ & 2 & & 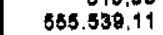 & & \\
\hline & & $\begin{array}{l}1.887 .88 \\
1.800 .5\end{array}$ & $\begin{array}{l}1.813 \\
1.826\end{array}$ & & & & & \\
\hline Cec & & $\begin{array}{r}3.800 .5 \\
320.0\end{array}$ & 323.1 & & & & & \\
\hline $\begin{array}{ll}\mathrm{CCV} \\
\text { Valo }\end{array}$ & & 16. & & & & & $\frac{8.047 .54}{22.178,26}$ & $\frac{12.269 .77}{33.814 .31}$ \\
\hline & & & & & & & & \\
\hline
\end{tabular}

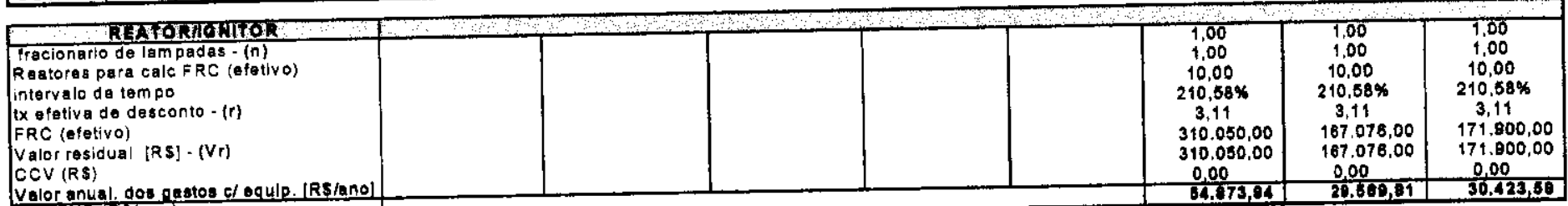

Velor anual. dos geatos e/ oqulp. IRssano

\begin{tabular}{|c|c|c|c|c|c|c|c|c|}
\hline \multirow{9}{*}{ 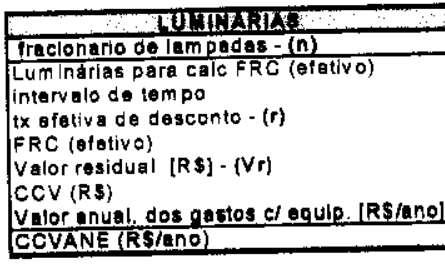 } & \multirow{2}{*}{\multicolumn{5}{|c|}{$\mathrm{CO} \mathrm{C}$}} & \multirow{2}{*}{$\frac{0,67}{1,00}$} & \multirow{2}{*}{$\frac{0,87}{100}$} & \multirow{2}{*}{0,50} \\
\hline & & & & & & & & \\
\hline & & & & & & & & $\begin{array}{l}1,00 \\
20,00\end{array}$ \\
\hline & & & & & & & $447,36 \%$ & $864.83 \%$ \\
\hline & & & & & & & & \\
\hline & & & & & & $\begin{array}{l}178.78,00 \\
578,688,47\end{array}$ & $\begin{array}{l}131.019,00 \\
422.882 .43\end{array}$ & $834.098,86$ \\
\hline & & & & & & & & \\
\hline & & & & & & $102.049,72$ & $74.000,100$ & $147.022,20$ \\
\hline & & & & & & & & \\
\hline 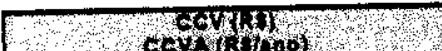 & $\begin{array}{l}767.166,00 \\
110,308,22\end{array}$ & $\begin{array}{l}1.108 .612,34 \\
320.070,04\end{array}$ & $\begin{array}{r}1.920,037,18 \\
323,103,20\end{array}$ & $\begin{array}{r}3.182,964,35 \\
860.794,60\end{array}$ & $1.468 .087,20$ & $300.749,77$ & $200.142,70$ & $371.810,17$ \\
\hline ced & $10.00+, 22$ & $21.240,30$ & $37.609,62$ & & & & & \\
\hline
\end{tabular}




\section{1 - Resumo do resultados}

\begin{tabular}{|c|c|c|c|}
\hline Fpuras so Mbrito & $\begin{array}{l}\text { Sistema } \\
\text { Eiciente }(\mathbf{)})\end{array}$ & $\begin{array}{l}\text { Ststema } \\
\text { Existonte (B) }\end{array}$ & $\begin{array}{c}\text { DIFERENÇA } \\
(\mathbf{A}-\mathrm{B})\end{array}$ \\
\hline \multirow{2}{*}{$\begin{array}{l}\text { CCV (R\$) } \\
\text { CCVA (R\$/ano) } \\
\text { CCVANE (R\$/ano) } \\
\text { CEE (R\$/MWh) }\end{array}$} & $\begin{array}{r}4.931 .530,05 \\
872.802,72 \\
540.844,47 \\
\end{array}$ & $\begin{array}{r}15.680 .607,78 \\
2.775 .219,26 \\
211.061,70\end{array}$ & $\begin{array}{c}(10.749 .077,73) \\
(1.902 .416,54) \\
329.782,77\end{array}$ \\
\hline & \multicolumn{3}{|c|}{36,02} \\
\hline
\end{tabular}

\section{4 - Cálculo da TIR}

\begin{tabular}{|r|c|c|c|}
\hline \multirow{2}{*}{ Ano } & \multicolumn{3}{|c|}{ Fluxo de caixa } \\
\cline { 2 - 4 } & Sistema existente & Sistema eficiente & Balanco \\
\hline $0\left(^{\star}\right)$ & $446.597,80$ & $2.767 .968,00$ & $(2.321 .370,20)$ \\
\hline $1\left(^{\star *}\right)$ & $2.775 .219,26$ & $872.802,72$ & $1.902 .416,54$ \\
\hline 2 & $2.775 .219,26$ & $872.802,72$ & $1.902 .416,54$ \\
\hline 3 & $2.775 .219,26$ & $872.802,72$ & $1.902 .416,54$ \\
\hline 4 & $2.775 .219,26$ & $872.802,72$ & $1.902 .416,54$ \\
\hline 5 & $2.775 .219,26$ & $872.802,72$ & $1.902 .416,54$ \\
\hline 6 & $2.775 .219,26$ & $872.802,72$ & $1.902 .416,54$ \\
\hline 7 & $2.775 .219,26$ & $872.802,72$ & $1.902 .416,54$ \\
\hline 8 & $2.775 .219,26$ & $872.802,72$ & $1.902 .416,54$ \\
\hline 9 & $2.775 .219,26$ & $872.802,72$ & $1.902 .416,54$ \\
\hline 10 & $2.775 .219,26$ & $872.802,72$ & $1.902 .416,54$ \\
\hline & \multicolumn{3}{|c|}{ TIR $=82 \%$ (calculado) }
\end{tabular}

(") No ano 0, considerou-se o investimento inicial em cada sistema.

(**) A partir do ano 1, considerou-se o CCVA para cada sistema.

\section{5 - Cálculo do serviço da dívida do financiamento}

\begin{tabular}{|c|c|}
\hline $\mathrm{IF}^{2}$ & R\$ 2.767.968,00 \\
\hline 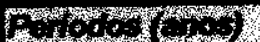 & 3 \\
\hline 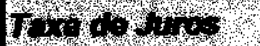 & $5 \%$ \\
\hline 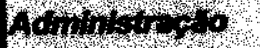 & $1 \%$ \\
\hline 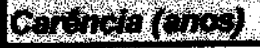 & 2 \\
\hline
\end{tabular}

\begin{tabular}{|c|c|c|c|c|c|c|}
\hline Perioda & Saldo Devedor & Juros & Corregäo Monetária & Principal & Administraça & Totel \\
\hline & $2.767 .968,00$ & $139.782,38$ & $27.679,68$ & & & \\
\hline 1 & $2935.430,06$ & $148.239,22$ & $29.354,30$ & & & \\
\hline 2 & $3.113 .023,58$ & $157.207,69$ & $31.130,24$ & $1.037 .674,53$ & $31.130,24$ & $1.257 .142,69$ \\
\hline 8 & $2.075 .349,06$ & $104.805,13$ & $20.753,49$ & $1.037 .674,53$ & $20.961,03$ & 1. $184.194,17$ \\
\hline & $1.037 .674,53$ & $52.402,56$ & $10.376,75$ & $1.037,674,53$ & $10.480,51$ & $1.110 .934,35$ \\
\hline
\end{tabular}




\section{6 - VPL Prefeitura Municipal}

6.1 - Considerando os custos diferenciais de investimento e reposição entre os sistemas existente e eficiente.

\begin{tabular}{|c|c|c|c|c|c|c|}
\hline 8. & $-2.321 .370,20$ & & & & $-2.321 .370,20$ & $-2.321 .370,20$ \\
\hline 1 & & $104.583,66$ & & $1.110 .180,42$ & $1.214 .764,09$ & $1.084 .610,79$ \\
\hline 2 & & $104.583,66$ & & $1.110 .180,42$ & $1.214 .764,09$ & $968.402,49$ \\
\hline 8 & & $104.583,66$ & $-1.230 .392,09$ & $1.110 .180,42$ & $-15.628,00$ & $-11.123,70$ \\
\hline 8 & & $104.583,66$ & $-1.143 .638,16$ & $1.110 .180,42$ & $71.125,93$ & $45.201,81$ \\
\hline 13 & & $104.583,66$ & $-1.056 .510,67$ & $\uparrow .110,180,42$ & $158.253,41$ & $89.797,24$ \\
\hline 8 & & $104.583,66$ & $-346.778,47$ & $1.110 .180,42$ & $867.985,62$ & $439.748,53$ \\
\hline 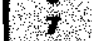 & & $104.583,66$ & $-309.895,18$ & $1 . \uparrow 10.180,42$ & $904.868,91$ & $409.316,74$ \\
\hline 1 & & $104.583,66$ & -273.011 .89 & $1.110 .180,42$ & $941.752,20$ & $380.357,92$ \\
\hline 6 & & $104.583,66$ & & $1.110 .180,42$ & $1.214 .764,09$ & $438.056,11$ \\
\hline 8 & & $104.583,66$ & & $1.110 .180,42$ & $1.214 .764,09$ & \\
\hline
\end{tabular}

Periodo anallsado (anos) 10

6.2 - Sem considerar o custo diferencial entre os sistemas.

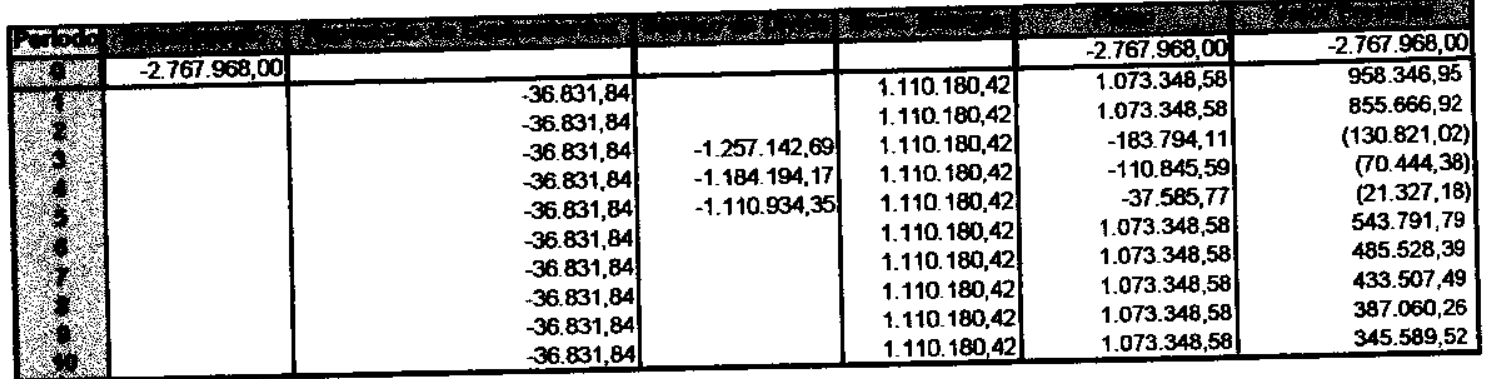

Perfodo analisado (anos) 10

R.7.078.950,74

7 and(s) e 4 moses

\section{7 - Resultado para Concessionária}

Considerando venda de parte da energia economizada a outras classes.

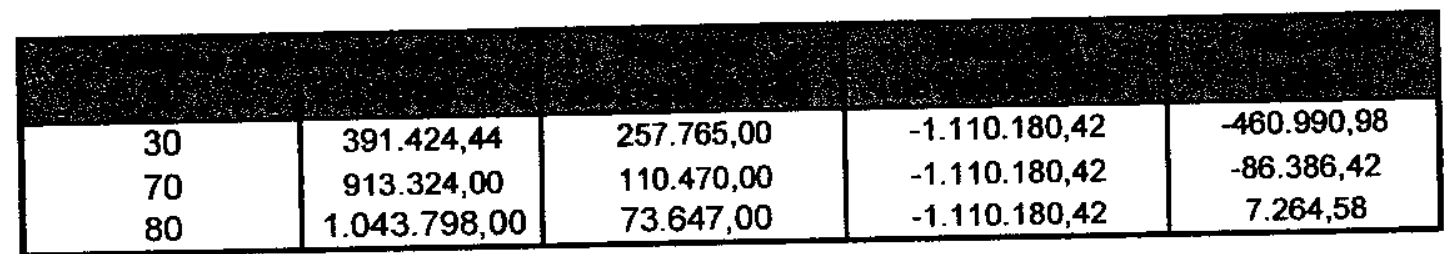

8 - Cálculo do RBC (De acordo com equação 5.5)

$R B C=\frac{(9.156 * 46,85)+(2.090 * 208,32)}{540.844,47}$

$\mathbf{R B C}=1,60$. 


\section{REFERÊNCIAS BIBLIOGRÁFICAS}

AGÊNCIA NACIONAL DE ENERGIA ELÉTRICA. Iluminação pública: panorama, desafios, alternativas de financiamento. Brasilia, D.F., ANEEL, 1999.

Manual para elaboração do programa anual de combate ao desperdicio de energia elétrica: ciclo 1999 / 2000. Brasilia, D.F., ANEEL, 1998.

Revisão da Portaria DNAEE 158/89: /Documento de referência para o Grupo de Estudos/ Brasília, D.F., ANEEL, 1998.

. Tarifas médias. Internet. http://www.aneel.gov.br/sre. 1999.

ALBINO DE OLIVEIRA, F. A. Concessões dos serviços públicos de energia elétrica: sua evolução no direito brasileiro. São Paulo, Revista de Direito Público, n.23, p.40-60, 1973.

ARAÚJO, I. M. T. et al. O programa de iluminação pública do PROCEL: reduçã́o do consumo de energia elétrica e melhoria da qualidade do serviço. In: XV SEMINÁRIO NACIONAL DE PRODUÇÄO E TRANSMISSÄO DE ENERGIA ELÉTRICA. Foz do Iguaçu, 1999. Anais. Foz do Iguaçu, SNPTEE, 1999.

ASSOCIAÇÃO BRASILEIRA DE NORMAS TÉCNICAS. lluminação pública: procedimento. NBR 5101. Rio de Janeiro, 1992.

ATALIBA, G. Hipótese de incidência tributária. 5 ed. São Paulo, Malheiros, 1995. (Coleção de Estudos de Direito Tributário)

BANCO MUNDIAL. Energía: eficiencia y conservación en el mundo en desarrollo. Función del Banco Mundial. Documento de política del Banco Mundial. Washington, D.C., Banco Mundial, 1993.

BARBOSA, R.; ALMEIDA, J. G. P. Manual de iluminação pública eficiente. Rio de Janeiro, IBAM - DUMA / ELETROBRÁS - PROCEL, 1998.

BARBOSA, R.; SAUER, I. L. Princípios e diretrizes para uma política de iluminação pública eficiente: o caso de João Pessoa - PB. In: VI! CONGRESSO BRASILEIRO DE ENERGIA E II SEMINÁRIO LATINO AMERICANO DE ENERGIA, IV., Rio de Janeiro, 1996. Anais. Rio de Janeiro, CBE, 1996, p.2261-2272. 
BORENSTEIN, C. R. ; CAMARGO, C. B. C. O setor elétrico no Brasil: dos desafios do passado às alternativas do futuro. Porto Alegre, Sagra Luzzatto, 1997.

BORN, P. H. Curso de microeconomia e custos marginais. Curitiba, COPEL, 1991. (Apostila, COPEL/DPDP, 2. ed., v. 1 e 2).

BURINI Jr., E. C.; CAUVILLA, P. R.; SAUER, I.L. Análise econômica de alternativas para iluminação. IApresentado ao VI Congresso Brasileiro de Energia/ Rio de Janeiro, outubro, 1993.

BURINI Jr., E. C.; MARQUES DOS SANTOS, M. M. M.; SAUER, I. L. Bases para política de iluminação pública. Estudo de caso. IApresentado ao II Congresso Brasileiro de Planejamento Energético, Campinas/ UNICAMP, 1994.

CAYLESS, M. A.; MARSDEN, A. M. Lamps and Lighting. 522p. Great Britain, Arnold, 3rd. ed., 1983.

CENTRO DA MEMÓRIA DA ELETRICIDADE - CME. Panorama do setor de energia elétrica no Brasil. Rio de Janeiro, Centro da Memória da Eletricidade no Brasil, 1988.

COMMISSION INTERNATIONALE DE L'ÉCLAIRAGE - CIE. Recommendations for the lighting of roads for motor and pedestrian trafic. CIE 115. CIE, 1995.

COMPANHIA DE ELETRICIDADE DO ESTADO DA BAHIA. Custos: Vitória da Conquista. Caracterização da carga. Salvador, COELBA, 1996. /Xerocopiado/

COMISSÃO MUNDIAL SOBRE MEIO AMBIENTE E DESENVOLVIMENTO CMMAD. Nosso futuro comum. 2 ed. Rio de Janeiro, Fundação Getúlio Vargas, 1991.

COMITÊ DE DISTRIBUIÇÃO - CODI. lluminação pública: procedimentos comerciais. Diagnóstico. 49p. Rio de Janeiro, CODI-SCSC, 1983.

lluminação pública: procedimentos comerciais. Recomendações. 27p. Rio de Janeiro, CODI-SCSC, 1984.

CONTADOR, C. R. Projetos sociais: avaliação e prática. São Paulo, Atlas, 1997.

COSTA, G. J. C. lluminação econômica: cálculo e avaliação. 503p. Porto Alegre, EDIPUCRS, 1998. 
DEPARTAMENTO NACIONAL DE ÁGUAS E ENERGIA ELÉTRICA. Nova tarifa de energia elétrica: metodologia e aplicação. Brasilia, D.F., DNAEE, 1985.

. Política de iluminação pública: relatório-síntese. Brasília, D.F., 1986.

DUTT, G. S. Electricity at least cost: a manual on the end-use-oriented approach to electricity supply in India. Princenton, Princenton University, The Center for Energy and Environmental Studies, 1993.

ELETROBRÁS. Panorama da iluminação pública no Brasil: cadastro nacional e potencial de conservação. Rio de Janeiro, ELETROBRÁS / PROCEL ,
1999.

Reserva global de reversão: sub-programa de conservação e eficiência energética. Manual de instruções para solicitação de financiamento. Rio de Janeiro, ELETROBRÁS / PROCEL , 1997.

lluminação pública: texto provocativo. ISEMINÁRIO INTERNACIONAL DE COMBATE AO DESPERDÍCIO DE ENERGIA ELÉTRICA. Efficientia 98. Rio de Janeiro, 1998. Rio de Janeiro, ELETROBRÁs, 1998.

FARIAS NETO, P. S. Gestão efetiva e privatização: uma perspectiva brasileira. Rio de Janeiro, Quallitymark, 1994.

FIGUEIREDO, F. M. Conceituação e aplicação de metodologia de gerenciamento pelo lado da demanda em uma empresa distribuidora de energia elétrica. São Paulo, 1997. 301p. Tese (Doutorado) - Escola Politécnica da Universidade de São Paulo.

FLAVIN, C. Construindo uma ponte para o uso sustentável de energia. In: BROWN, L. R., org. Qualidade de vida -1992: salve o planeta. Worldwatch Institute/. São Paulo, Globo, 1992. p.49-71.

FLAVIN, C.; LENSSEN, N. Remodelando a indústria de energia. In: BROWN, L. R., org. Qualidade de vida -1994: salve o planeta. Worldwatch Institute/. São Paulo, Globo, 1994. p.88-109.

GARDNER, D. T; ROBINSON, B. J. To what end: a conceptual framework for the analysis of energy uses. Energy Studies Review, v.5, n.1. p.1-14.

GELLINGS, C. W. Then and now: the perspective of the man who coined the term DSM. Energy policy, v.24, n.4, p.285-288, april, 1996.

GUILLO, V. A; SAUER, I. L. Regulação dos monopólios naturais: o caso das tarifas de distribuição de energia elétrica. In: VIII CONGRESSO BRASILEIRO 
DE ENERGIA E III SEMINÁRIO LATINO AMERICANO DE ENERGIA, IV., Rio de Janeiro, 1999. Anais. Rio de Janeiro, CBE, 1999.

HÉMERY, D.; DEBIER, J. C.; DELÉAGE, J. P. Uma história da energia. Trad. de Sérgio de Salvo Brito. Brasília, D.F., Universidade de Brasília, 1993.

HOLDREN, J. Energy in trasition. Scientific American, september, p.156-163, 1990.

HIRST, E. Improving energy efficiency in the USA: the federal role. Energy Policy, v.19, n.6, p.567-577, july/August, 1991.

INSTITUTO BRASILEIRO DE ADMINISTRAÇÃO MUNICIPAL. O município e a iluminação pública: relatório final. Rio de Janeiro, 1984.

Pesquisa sobre iluminação pública nos município brasileiros: resultados. Rio de Janeiro, IBAM - DUMA / ELETROBRÁS - PROCEL, 1997.

JOHNSON, B. B. et al. Serviços públicos no Brasil: mudanças e perspectivas. Concessão, regulamentação, privatização e melhoria da gestão pública. São Paulo, Edgard Blücher, 1996.

KIRSCHBAUM, C. F. Reconversión del alumbrado público: impacto ambiental y en el usuario. In: I SEMINÁRIO INTERNACIONAL SOBRE EFICIÊNCIA EM ILUMINAÇÃO PÚBLICA. Rio de Janeiro, 1997. Anais. Rio de Janeiro, Artimagem, 1997, p.145-157.

LENSSEN, N. A provisão de energia nos países em desenvolvimento. In: BROWN, L. R., org. Qualidade de vida-1994: salve o planeta. Morldwatch Institutel. São Paulo, Globo, 1993. p.141-163.

LIMA, J. L. Políticas de governo e desenvolvimento do setor de energia elétrica: do Código de Águas à crise dos anos 80 (1934-1984). Rio de Janeiro, Memória da Eletricidade, 1995.

MEIRELLES, H. L. Estudos e pareceres de direito público. São Paulo, Revista dos Tribunais Ltda., 1988. v 10.

MIGUEZ, J. C. O urbanismo luz. In: I SEMINÁRIO INTERNACIONAL SOBRE EFICIÊNCIA EM ILUMINAÇÃO PÚBLICA. Rio de Janeiro, 1997. Anais. Rio de Janeiro, Artimagem, 1997, p.62-66.

PEDRANTI, A. Eficiência energética num mercado restruturado: o caso da iluminação pública em Cipolletti, Argentina. São Paulo, 1997. 146p. Dissertação (Mestrado) - Instituto de Eletrotécnica e Energia, Escola 
Politécnica, Faculdade de Economia e Administração, Instituto de Física, Universidade de São Paulo.

PINDYCK, R. S.; RUNBINFELD, L. D. Microeconomia. São Paulo, Mackron Books, 1994.

PREFEITURA MUNICIPAL DE JOÃO PESSOA - PMJP. Diagnostico dos serviços de iluminação pública em João Pessoa. João Pessoa, PMJP / SEPLAN, 1997.

RAAD, A. Análise das barreiras à eficiência energética e de suas soluções no caso do setor elétrico brasileiro. Rio de Janeiro, 1999. 261p. Dissertação (Mestrado) - COPPE, Universidade Federal do Rio de Janeiro.

REDDY, A. K. N. Barriers to improvements in energy efficiency. Energy Policy, December, 1991, p.953-961.

RIANI, F. Economia do setor público: uma abordagem introdutória. 2. ed. São Paulo, Atlas, 1994.

SAUER, I. L., et al. Iniciativa para o planejamento integrado de recursos do setor elétrico no estado de Roraima. IApresentado ao II Congresso Brasileiro de Planejamento Energéticol. Campinas, UNICAMP, 1994.

SAUER, I. L. coord. Métodos de análise energética a partir dos usos finais. Programa de exercícios. São Paulo, USP/IEE, 1994. Morshop Internacional/ Programa Interunidades de Pós-Graduação em Energia da Universidade de São Paulo. IXerocopiado/

SOCIEDADE ANÔNIMA DE ELETRIFICAÇÃO DA PARAÍBA. Relatório de acompanhamento de mercado. João Pessoa, 1999.

TESCONI, M. A luz ao serviço da cidade. In: I SEMINÁRIO INTERNACIONAL SOBRE EFICIÊNCIA EM ILUMINAÇĀO PÚBLICA. Rio de Janeiro, 1997. Anais. Rio de Janeiro, Artimagem, 1997, p103-118.

U.S. Agency for International Development - USAID. Strategies for Financing Energy Efficiency. Office of Energy Environment, and Technology. Center for Enviroment Bureau for Global Progams, Field Support, and Research. Washington, DC, 1996.

VEITCH, J. A.; NEWSHAN, G. R. Quantificando a qualidade com base no desempenho e na preferência do usuário. Eletricidade Moderna, n. 258, agosto, 1995. 
VIZHÑAY, J. P. M. Uso eficiente de energia elétrica no setor de iluminação pública do Equador. São Paulo, 1996. 224p. Dissertação (Mestrado) Instituto de Eletrotécnica e Energia, Universidade de São Paulo. 


\section{APÊNDICES}




\section{APÊNDICE A PROJetos de SISTEMAS de ILUMINAÇÃo PÚBlicA EFICIENTES*}

Projetar um sistema de iluminação pública eficiente significa satisfazer diversos critérios qualitativos para atender as necessidades visuais dos seus usuários, utilizando de forma adequada as tecnologias disponíveis no mercado. Isso requer o conhecimento das principais características dos equipamentos eficientes utilizados para iluminação pública e dos parâmetros básicos de qualidade mais importantes na iluminação de logradouros públicos.

\section{METOdologia PARA ELABORAÇĀO DE UM PROJETO DE IP}

\subsection{Projetos de implantação de novos sistemas}

O primeiro passo para a elaboração de um projeto de IP eficiente é classificar o tipo de via que será iluminada, para definição dos parâmetros luminotécnicos apropriados. Os parâmetros de qualidade para vias de tráfego motorizado adotados pela NBR 5101, são níveis e fator de uniformidade de iluminâncias, cujos valores médios mínimos são estabelecidos de acordo com a classificação da via pública, segundo sua importância, tipo e volume de tráfego de veículos e de pedestres.

Os tipos de vias públicas e a classificação segundo o volume de tráfego de veículos e pedestres propostos pela NBR 5101, são apresentados nas tabelas A1, A2, respectivamente. $O$ segundo passo deve ser a escolha de lâmpadas e luminárias mais adequadas. $O$ terceiro, a determinação dos seguintes parâmetros: altura de montagem, espaçamento e disposição dos postes. O passo final é realização dos cálculos luminotécnicos buscando otimizar o projeto com base nos valores recomendados nas normas.

\section{a) Tipos de Vias para Iluminação Pública}

A NBR 5101 - Iluminação Pública - Procedimento,-estabelece os tipos de vias públicas de acordo com a sua natureza e função. Assim, as vias públicas podem ser definidas como:

- Vias rurais ou classe A - exclusivas para o tráfego motorizado. Subdividem-se em:

A1 - vias arteriais;

A2 - vias coletoras;

$\mathrm{A} 3$ - vias locais.

- Vias de ligação ou classe B - responsáveis pela ligação entre centros urbanos e suburbanos.

\footnotetext{
* Fonte: BARBOSA ; ALMEIDA (1998).
} 
- Vias urbanas ou classe $C$ - caracterizada pela presença de construções às suas margens e tráfego motorizado e de pedestres. Subdividem-se em:

$\mathrm{C} 1$ - vias principais;

$\mathrm{C} 2$ - vias normais;

C3 - vias secundárias;

$\mathrm{C} 4$ - vias irregulares.

- Vias especiais ou classe D - acessos e/ou vias exclusivas para pedestres.

A figura A1 ilustra os tipos de vias, segundo os critérios da NBR 5101.

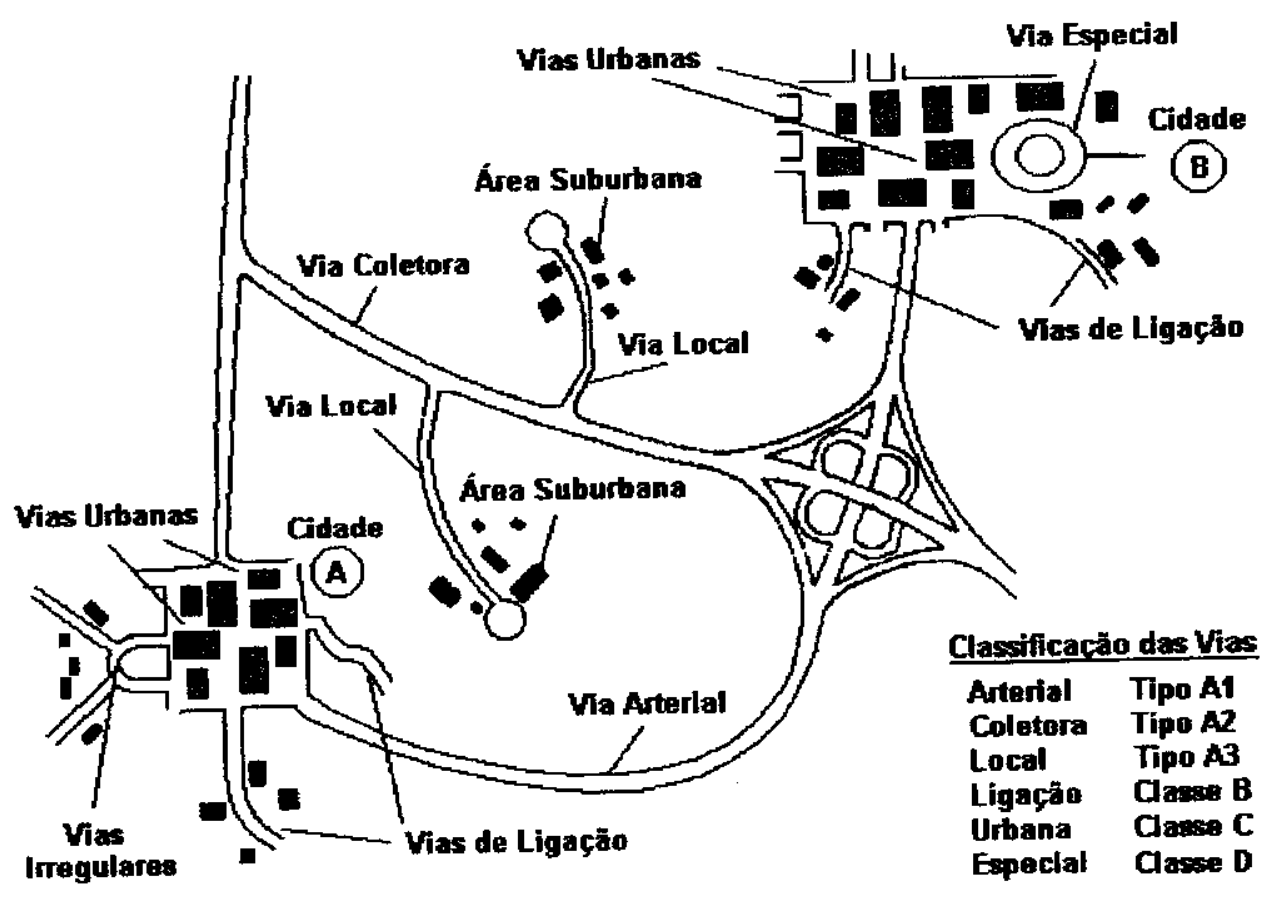

Figura A1 - Tipos de vias públicas.

\section{b) Classificação do Volume de Tráfego em Vias Públicas}

A NBR 5101 também estabelece a classificação das vias públicas de acordo com o volume de tráfego noturno de veículos e/ou de pedestres que passam nessa via num período de 1 hora. As tabelas A1 e A2 apresentam essas classificações.

TABELA A1 - Classificação de vias em função do tráfego motorizado.

\begin{tabular}{l|c}
\hline CLASSIFICAÇĀO & $\begin{array}{c}\text { NÚMERO DE VEíCULOS POR } \\
\text { HORA* }\end{array}$ \\
\hline Leve (L) & 150 a 500 \\
\hline Médio (M) & 501 a 1.200 \\
\hline Intenso (I) & Acima de 1.200 \\
\hline $\begin{array}{l}\text { *Esses valores se reférem ao trânsito médio de veículos } \\
\text { em pista única e de mão dupla, medidos entre } 18 \mathrm{e} 21 \mathrm{~h} .\end{array}$
\end{tabular}


TABELA A2- Classificação de vias em função do tráfego de pedestres.

\begin{tabular}{|l|l|}
\hline CLASSIFICAÇĀO & $\begin{array}{l}\text { PEDESTRES CRUZANDO VAS } \\
\text { COM TRÁFEGO MOTORIZADO* }\end{array}$ \\
\hline Sem (S) & Como nas vias de classe Al \\
\hline Leve (L) & Como nas vias residenciais médias \\
\hline Médio (M) & Como nas vias comerciais secundárias \\
\hline Intenso (I) & Como nas vias comerciais principais \\
\hline
\end{tabular}

* Esses valores se referem ao trânsito de pedestre, medidos entre $18 \mathrm{e} 21 \mathrm{~h}$.

\section{c) Níveis de Iluminância em Vias Públicas}

Experiências realizadas na Europa e EUA constataram que, visando assegurar uma boa visão a pedestres e motoristas, devem ser utilizados níveis de iluminância variando entre 10 e 30 lux. Dentro desta faixa, o poder de percepção do condutor de um veículo aumenta consideravelmente, mas para valores acima de 30 lux o ganho é pequeno. Com base nesses resultados, a ABNT, através da norma NBR 5101, fixou os níveis mínimos de iluminância necessários à iluminação de vias públicas, de acordo com sua importância, tipo e volume de tráfego, os quais são destinados a propiciar segurança a pedestres e veículos.

A tabela A3 apresenta os valores de iluminância média mínima para vias públicas recomendados pela NBR 5101. 
TABELA A3 - Níveis de iluminância para vias públicas.

\begin{tabular}{|c|c|c|c|c|}
\hline \multirow[t]{3}{*}{$\begin{array}{l}\text { TIPOS } \\
\text { DE } \\
\text { VIAS }\end{array}$} & \multirow[t]{3}{*}{$\begin{array}{c}\text { VOLUME } \\
\text { DE } \\
\text { PEDESTRES } \\
\end{array}$} & \multicolumn{3}{|c|}{$\begin{array}{l}\text { NÍVEIS MÉDIOS } \\
\text { MÍNIMOS DE ILUMINÂNCIA } \\
\text { (lux) }\end{array}$} \\
\hline & & VO & DE & LOS \\
\hline & & $\mathbf{L}$ & $\mathbf{M}$ & I \\
\hline \multirow{3}{*}{ Principais } & $\mathbf{L}$ & 2 & 5 & 10 \\
\hline & $\mathbf{M}$ & 5 & 8 & 12 \\
\hline & $I$ & 10 & 12 & 16 \\
\hline \multirow{3}{*}{ Ligação } & $\mathbf{L}$ & 2 & 5 & 10 \\
\hline & $\mathbf{M}$ & 5 & 10 & 14 \\
\hline & $I$ & 10 & 14 & 17 \\
\hline \multirow{3}{*}{ Normais } & $\mathbf{L}$ & 2 & 5 & - \\
\hline & $\mathbf{M}$ & 5 & 8 & - \\
\hline & $\mathbf{I}$ & 8 & 10 & - \\
\hline \multirow{3}{*}{ Locais } & $\mathbf{L}$ & 2 & 5 & - \\
\hline & $\mathbf{M}$ & 5 & 10 & - \\
\hline & $I$ & 10 & 14 & - \\
\hline \multirow{2}{*}{ Secundárias } & $\mathbf{L}$ & 2 & 2 & - \\
\hline & $\mathbf{M}$ & 4 & 5 & - \\
\hline Especiais & I & \multicolumn{3}{|c|}{10} \\
\hline Arteriais & - & \multicolumn{3}{|c|}{20} \\
\hline Coletoras & - & \multicolumn{3}{|c|}{20} \\
\hline
\end{tabular}

Fonte: NBR 5101.

(L - LEVE, M - MÉDIO e I - INTENSO).

\section{d) Fator de Uniformidade de Iluminância}

O fator de uniformidade (U), é a relação entre o menor valor de iluminância em uma área considerada e o valor da iluminância média nessa mesma área. Quanto mais próximo de 1, mais uniforme será a iluminação da via. $\mathbf{U}$ é expresso pela fórmula:

$$
U=\frac{E_{\text {min }}}{E_{\text {med }}}, \text { sendo }
$$

Emin. e Emed. os menores valores de iluminância e iluminância média, respectivamente. $O$ valor da iluminância média é obtido através da média aritmética das leituras dos valores iluminância da área em estudo, medidas em plano horizontal sobre o nível da via. Os valores mínimos para o fator de uniformidade de iluminância recomendados pela NBR 5101, em função do tipo de via e do volume de tráfego de pedestres e de veículos, são os seguintes:

- Nas vias locais (A3), normais (C2) e especiais (D), o valor de uniformidade de iluminância mínimo recomendado é de 0,2 , para qualquer volume de tráfego; 
- Nas vias de ligação (B) e nas vias principais (C1), para volumes de tráfego leve e médio, Umin. $=0,2$, e para tráfego intenso, Umin. $=0,25$;

- Nas vias secundárias (C3), para tráfego leve, Umin. $=0,2$, e para tráfego médio, Umin. $=0,25$

- Nas vias arteriais (A1) e nas vias coletoras (A2), para qualquer volume de tráfego, Umin. $=0,50$ e 0,30 , respectivamente.

\section{e) Fator de Desuniformidade de Iluminância}

Mesmo não constando da NBR 5101, diversas empresas e projetistas adotam como alternativa ao fator de uniformidade, o critério de fator de desuniformidade (Fd). Este fator é a relação entre o maior valor de iluminância em uma área considerada e o menor valor de iluminância nessa mesma área, e é expresso pela fórmula:

$$
F_{d}=\frac{E_{\max }}{E_{\min }}, \text { sendo }
$$

$E_{\max }$ e $E_{\min }$, o maior e o menor valores de iluminâncias, respectivamente. Quanto menor o Fd, maior será a uniformidade da iluminação na via. Valores sugeridos para o fator de desuniformidade são apresentados na tabela A4.

Tabela A4 - Fator de desuniformidade.

\begin{tabular}{|l|c|}
\hline \multicolumn{1}{|c|}{$\begin{array}{c}\text { TIPO } \\
\text { DE VIA }\end{array}$} & $\begin{array}{c}\text { FATOR DE } \\
\text { DESUNIFORMIDADE }\end{array}$ \\
\hline Especiais & $<5$ \\
\hline Principais & $<7$ \\
\hline Ligação & $<7$ \\
\hline Normais & $<9$ \\
\hline Locais & $<15$ \\
\hline Secundárias & $<20$ \\
\hline
\end{tabular}

\section{f) Escolha de Lâmpadas e Luminárias}

Nos projetos de iluminação pública, a escolha das lâmpadas e das luminárias a serem utilizadas em determinado logradouro público deve ser feita em função de critérios luminotécnicos, econômicos e de manutenção. Algumas dicas nesse sentido, são apresentadas a seguir:

- Utilizar, preferencialmente, as lâmpadas VSAP, pois apresentam uma série de vantagens técnicas e econômicas quando comparadas com as outras lâmpadas de descarga.

- Não é recomendado a utilização de lâmpadas com diferentes temperaturas de cor (TCC), por exemplo: VSAP e VM em uma mesma área, tendo em vista a dificuldade de adaptação cromática do olho humano. 
- As lâmpadas a vapor de mercúrio devem ficar restritas à manutenção da iluminação existente e à pequenas extensões de IP onde já exista vapor de mercúrio.

- A luminária adequada depende das características do logradouro no qual vai ser instalada e do tipo de lâmpada a ser utilizada, sendo importante verificar o seu grau
de proteção (IP) e sua viabilidade econômica.

- Utilizar luminárias com equipamento incorporado, considerando a facilidade de manutenção, pois os principais equipamentos estão em um mesmo ponto, evitando que o eletricista tenha que se deslocar no poste durante o trabalho de substituição.

\section{g) Altura de Montagem}

O próximo passo na elaboração de um projeto luminotécnico, após a determinação dos níveis de iluminância e escolha da lâmpada e da luminária, é a determinação da altura de montagem $(\mathrm{Hm})$, do espaçamento ou vão (e), e do posicionamento de postes. A seguir serão apresentados alguns critérios para a especificação desses valores.

Para definição da altura de montagem da luminária e da distância entre os postes, o projetista pode adotar as seguintes regras práticas:

$$
H m \geq L \text { e } e \leq 3 . H m
$$

sendo:

$$
\begin{aligned}
& H m=\text { altura de montagem da luminária; } \\
& L=\text { largura da pista mais acostamento; } \\
& \boldsymbol{e}=\text { espaçamento entre postes. }
\end{aligned}
$$

É importante lembrar que a utilização de lâmpadas de fluxo luminoso elevado em baixas alturas de montagem pode comprometer todo o projeto luminotécnico de uma via. Nesse caso, é comum observar-se o efeito de "zebramento" (fator de desuniformidade elevado, ou fator de uniformidade baixo), e, no caso de iluminação
ornamental, ofuscamento excessivo. 
Para evitar que isso ocorra, devem ser observadas as relações entre fluxo luminoso e altura de montagem apresentadas na tabela A5.

TABELA A5 - Altura de montagem em função do fluxo luminoso.

\begin{tabular}{|c|c|}
\hline $\begin{array}{c}\text { ALTURA } \\
\text { DE } \\
\text { MONTAGEM (Hm) }\end{array}$ & $\begin{array}{c}\text { FLUXO } \\
\text { LUMINOSO } \\
\text { MÁXIMO [lm] }\end{array}$ \\
\hline$>3$ e até $4 \mathrm{~m}$ & 6.500 \\
\hline$>4$ e até $8 \mathrm{~m}$ & 14.000 \\
\hline$>8$ e até $12 \mathrm{~m}$ & 25.500 \\
\hline Acima de $12 \mathrm{~m}$ & 46.500 \\
\hline
\end{tabular}

Com a utilização de luminárias mais eficientes, o espaçamento (e) poderá chegar a até 5 vezes a altura de montagem $(\mathrm{Hm})$.

\section{h) Altura dos Postes e Manutenção}

Na escolha da altura de montagem para uma luminária deve se prevista a disponibilidade de veículos adequados à sua manutenção. A utilização de postes com altura de montagem superior a 14 metros poderá, eventualmente, impossibilitar a manutenção através de veículos convencionais, utilizados pela maioria das empresas de manutenção. $O$ projetista deverá também verificar determinadas características das vias, tais como volume de tráfego de veículos, importância para o comércio e turismo, considerando os transtornos que os serviços de manutenção podem acarretar nesse casos.

\subsection{Disposição de postes e luminárias}

Após a escolha do tipo de lâmpada, da luminária, e da definição da altura de montagem, o projetista deverá especificar a disposição dos postes na via.

Quatro tipos básicos de locação de postes podem ser adotados em função da via que será iluminada:

- posteação unilateral;

- posteação bilateral alternada;

- posteação bilateral ou frente a frente, $\mathrm{e}$

- central.

A partir destes quatro tipos básicos de posteação, o projetista deverá obter os níveis mínimos de iluminância apresentados na tabela $\mathrm{A} 3$, observados os critérios de disposição de luminárias, tipo de lâmpadas e altura de montagem recomendados. 


\section{a) Posteação Unilateral}

A posteação unilateral deve ser utilizada quando a largura da pista $(\mathbf{L})$ for igual ou menor que a altura de montagem $(\mathbf{H m})$ da luminária, conforme figura A2.

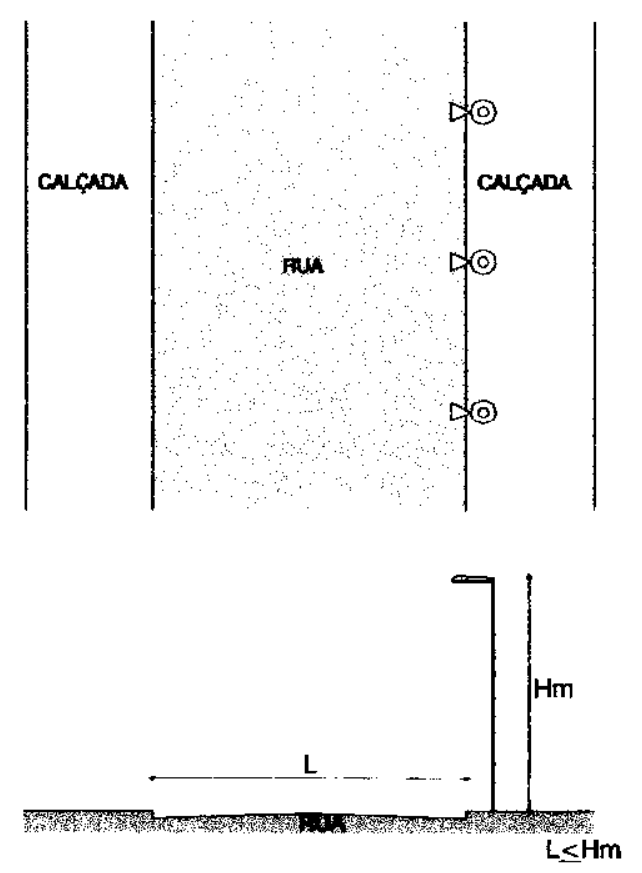

Figura A2 - Posteação unilateral.

Neste caso, é de se esperar que a iluminância da parte oposta da pista em relação à posição das luminárias seja menor do que a do lado das luminárias.

\section{b) Posteação Bilateral Alternada}

Quando a largura da pista estiver entre 1,0 e 1,6 vezes a altura da montagem da luminária deve ser utilizada a posteação bilateral alternada. A figura A4 apresenta esse posicionamento. 

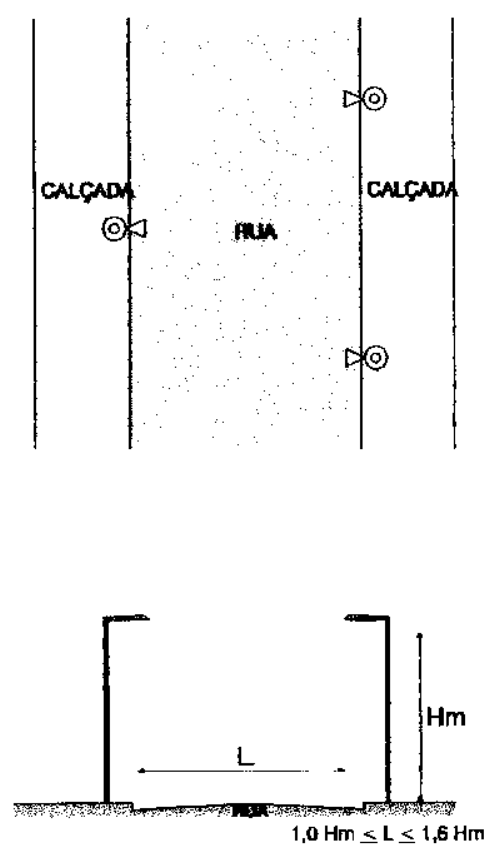

Figura A4 - Posteação bilateral alternada.

\section{c) Posteação Bilateral Frente a Frente}

A posteação bilateral frente a frente, é utilizada quando a largura da pista for superior a 1,6 vezes a altura de montagem da luminária, conforme mostrado na figura A5.
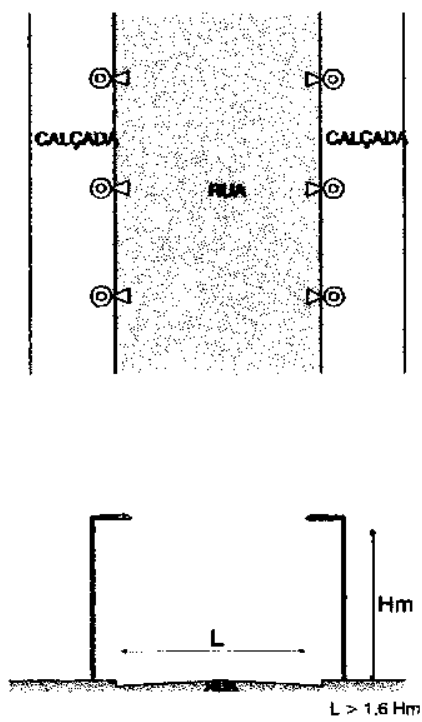

Figura A5 - Posteação bilateral frente a frente.

\section{d) Posteação Central}

A posteação no canteiro central é usada quando a largura da pista é maior que 1,6 vezes a altura de montagem das luminárias e a largura do canteiro central (D) não ultrapasse a 6 metros, conforme ilustrado na figura A6. 

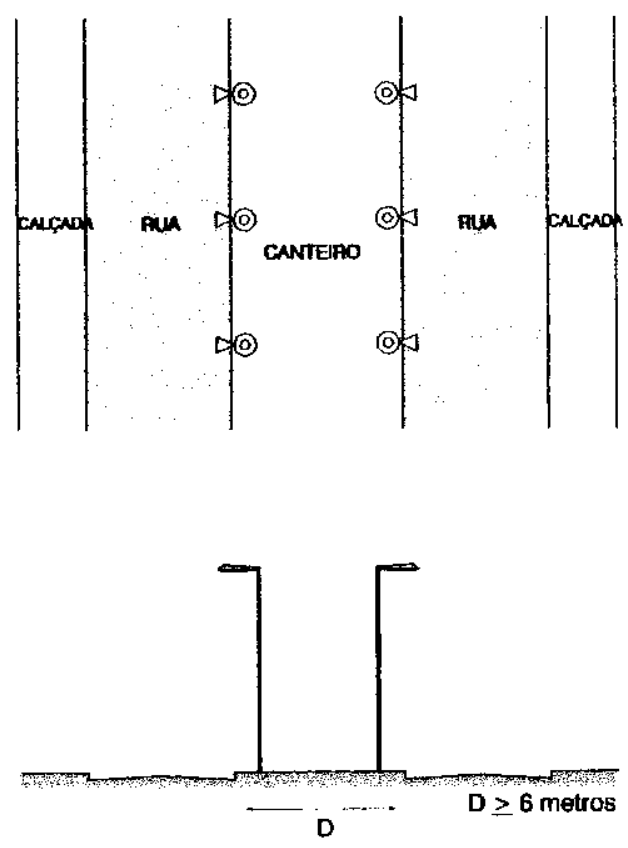

Figura A6 - Posteação central.

\section{3 - Projeto de melhoria da eficiência energética de sistemas de iluminação pública existentes}

Melhorar a eficiência energética de um sistema de iluminação pública pode ser uma tarefa de relativa facilidade. Em alguns casos, a simples substituição das lâmpadas ineficientes por lâmpadas VSAP - utilizando-se as mesmas luminárias -, proporciona uma melhor iluminação com a redução da conta de energia elétrica e dos gastos com manutenção.

Entretanto, dependendo da situação do sistema de IP, a melhoria da eficiência energética, deve ser precedida de critérios e procedimentos técnico-econômicos, sob pena de não se obter os resultados esperados, frustrando, assim, a expectativa dos usuários.

\section{a) Procedimentos Básicos}

Para melhorar a qualidade de um sistema de IP e torná-lo mais eficiente do ponto de vista energético, recomenda-se adotar os seguintes procedimentos básicos:

- Efetuar inspeção prévia nas das instalações de IP do sistema atual;

- Verificar, através de medição, os níveis e a uniformidade de iluminância do sistema atual;

- Verificar as luminárias e demais equipamentos que devem ser substituídos, não só pelo estado de depreciação, mas para adequá-los aos padrões e normas de eficiência estabelecidos.

- Obter informações técnicas sobre os equipamentos eficientes de IP;

- Definir as alternativas de substituição de lâmpadas;

- Coletar os preços das lâmpadas, luminárias e demais equipamentos a serem implantados. 


\section{APÊNDICE B METODOLOGIA DE CÁLCULO DAS TARIFAS BASEADAS NOS CUSTOS MARGINAIS: o exemplo da iluminação pública*}

1. Custos de capacidade de um cliente ou responsabilidade de um cliente nos custos de desenvolvimento de capacidade

O cálculo do custo marginal de capacidade de um cliente é realizado com base num modelo probabilístico que considera as seguintes premissas:

- Os custos de desenvolvimento de capacidade de linhas e redes são agregados por função e referidos a cada nível tarifário;

- A clientela é retratada por curvas de cargas típicas, definindo-se os clientes-tipo que deverão compor cada uma das parcelas do mercado para as quais serão calculadas as tarifas;

- Da mesma forma, são obtidas curvas de carga típicas dos elementos do sistema (linhas, redes e postos de transformação), caracterizando o que se denomina redestipo.

Dentro deste cenário, ficam definidas as contribuições de um cliente-tipo para a formação das demandas máximas das redes-tipo, o que permite a determinação dos seus custos de capacidade.

\section{Formulacão matemática}

- Seja h qualquer horário em que pode ocorrer a demanda máxima de uma rede-tipo de um nível.

- Seja $\mathbf{T}$ o conjunto de horários com possibilidade de ocorrência de demandas máximas das redes-tipo do nível.

- Denote-se por $\beta_{h}$ a parte da energia que transita em cada rede-tipo, com demanda máxima no horário $\mathbf{h}$, devida aos clientes de um dado tipo.

- Denote-se por $\boldsymbol{\alpha}_{\mathrm{h}}$ a participação das redes de cada tipo, com demanda máxima no horário $h$, na energia que transita no nível.

- A parte da energia dos clientes desse tipo, associada às redes tipo com demandas máximas em um particular horário t, é calculada pela expressão:

$$
\pi_{t}=\frac{\sum_{h=\mathrm{t}} \beta_{h \cdot \alpha_{h}}}{\sum_{\mathrm{T}} \beta_{h} \cdot \alpha_{h}}
$$

\footnotetext{
" Fonte: DNAEE (1985)
} 
A expressão B.1 representa a probabilidade do cliente marginal de um dado tipo se associar a uma rede cuja ponta ocorre no horário $t$.

$\beta_{\mathrm{h}}$ e $\alpha_{\mathrm{h}}$ representam, respectivamente, a probabilidade do cliente marginal ser de um dado tipo, se a rede à qual ele se associa tem a ponta no horário $\mathrm{h}$ (probabilidade condicionada), e a probabilidade de que a rede à qual o cliente marginal (qualquer que seja o tipo) se associa tenha a ponta no horário $h$.

Uma vez que um cliente marginal pode se associar a qualquer rede tipo de um nível, a demanda marginal nesse nível dependerá da demanda do cliente no horário de ponta da rede à qual ele se associa. Considerando a aleatoriedade dessa associação, o valor esperado da demanda marginal é dado pela soma das demandas dos clientes-tipo nos horários de ocorrência das pontas das redes-tipo, ponderadas pelas respectivas probabilidades de associação.

Esse valor denomina-se responsabilidade de potência do cliente e é obtida pela seguinte expressão:

$$
P_{\mathrm{u}}=\left(1+\tau_{u}\right) \cdot \sum_{h \in u} \pi_{h}{ }^{*} P_{u} \quad(B .2)
$$

onde:

$\mathbf{P u}=$ responsabilidade de potência do cliente no posto tarifário $u$, incluindo a perda acumulada desde o ponto de conexão do cliente até o nível em consideração.

$\tau_{\mathbf{u}}=$ taxa média de perda de potência no posto $u$ acumulada desde o ponto de conexão do cliente até a origem do nível em consideração.

$\pi_{\mathrm{h}}=$ probabilidade do cliente marginal de um dado tipo se associar a uma redetipo cuja ponta ocorre no horário $\mathrm{h}$ dentro do posto tarifário $\mathrm{u}$.

$\mathbf{P}_{\mathbf{h}}=$ demanda do cliente-tipo no horário $h$.

\subsection{Custo de capacidade relativo ao nível de produção}

- Posto Ponta: $\mathbf{C}_{\mathbf{P}}=\hat{\mu}$.P.P

- Posto Fora da Ponta: $\mathbf{C}_{\mathbf{F P}}=\hat{\mu} \cdot \mathbf{P}_{\mathrm{FP}}$

onde,

$\hat{\mu}=$ custo marginal de potência de produção.

$\mathbf{P}_{\mathbf{P}}=$ responsabilidade de potência do cliente na ponta, acumulada desde o ponto de conexão até a produção.

$\mathbf{P}_{\mathbf{F P}}=$ responsabilidade de potência do cliente fora da ponta, acumulada desde o ponto de conexão até a produção. 
1.2 Custo de capacidade relativo a um nível de tarifário ou a um nível de rede (linhas, redes ou postos de transformação)

- Posto Ponta: $\mathbf{C n}_{\mathbf{p}}=\delta_{\mathbf{n}} \cdot \mathbf{P n} \mathbf{p}$

- Posto Fora da Ponta: $\mathbf{C n}_{\mathrm{FP}}=\delta_{n} \cdot \mathbf{P} \mathbf{n}_{\mathrm{FP}}$ onde,

$\delta_{\boldsymbol{n}}=$ custo de desenvolvimento de capacidade ou custo marginal no nível $\mathbf{n}$.

$\mathbf{P} \mathbf{n}_{\mathbf{P}}=$ responsabilidade de potência do cliente na ponta, acumulada desde o ponto de conexão até o nível em consideração.

$\mathbf{P} \mathbf{n}_{\mathrm{FP}}=$ responsabilidade de potência do cliente fora da ponta, acumulada desde o ponto de conexão até o nível em consideração.

1.3 Custo total de capacidade ou componente de capacidade do custo marginal do cliente

- Posto Ponta: $\mathbf{C}_{\mathbf{T P}}=\mathbf{C}_{\mathbf{P}}+\Sigma \mathbf{C n}_{\mathbf{P}}=\hat{\mu} \cdot \mathbf{P}_{\mathbf{P}}+\Sigma \boldsymbol{\delta}_{\boldsymbol{n}} \cdot \mathbf{P} \mathbf{n}_{\mathbf{P}}$

- Posto Fora da Ponta: $\mathbf{C}_{\mathbf{T F P}}+\Sigma \mathbf{C n}_{\mathrm{FP}}=\hat{\mu} \cdot \mathbf{P}_{\mathrm{FP}}+\Sigma \delta_{n} \cdot \mathbf{P} \mathbf{n}_{\mathrm{FP}}$

\section{Custo de energia de um cliente}

A componente de energia do custo marginal de um cliente é calculada a partir dos custos marginais de energia de produção e do consumo do cliente-tipo, nos quatro postos tarifários horo-sazonais, acrescidos das perdas acumuladas desde o ponto de conexão do cliente até a produção.

- Posto Ponta - período seco: PS

$$
\mathbf{C}_{\mathrm{E} / \mathrm{PS}}=\tilde{\mu} \cdot \mathbf{P S} \cdot\left(1+\tau \mathbf{P}_{\mathrm{P}}\right) . \mathbf{E}_{\mathrm{PS}}
$$

- Posto Ponta - período úmido: PU

$$
\mathbf{C}_{\mathrm{E} / \mathrm{PU}}=\tilde{\mu} \cdot \mathbf{P U} \cdot\left(1+\tau \mathbf{P}_{\mathrm{P}}\right) . \mathbf{E}_{\mathrm{PU}}
$$

- Posto Fora de Ponta - período seco: FS

$$
\mathrm{C}_{\mathrm{E} / \mathrm{FS}}=\tilde{\mu} \cdot \mathrm{FS} \cdot\left(1+\tau \mathbf{P}_{\mathrm{FP}}\right) . \mathbf{E}_{\mathrm{FS}}
$$

- Posto Fora de Ponta - período úmido: FU

$$
\mathbf{C}_{\mathrm{E} / \mathrm{FU}}=\tilde{\mu} \cdot \mathrm{FU} \cdot\left(1+\tau \mathbf{P}_{\mathrm{FP}}\right) . \mathbf{E}_{\mathrm{FU}}
$$

onde,

$\widetilde{\mu} \cdot \mathrm{PS}, \widetilde{\mu} \cdot \mathrm{PU}, \widetilde{\mu} \cdot \mathrm{Fs}$ e $\widetilde{\mu} \cdot \mathrm{FU}$, são os custos marginais de energia de produção na ponta e fora de ponta, respectivamente nos períodos seco e úmido.

$\tau \mathbf{P}_{\mathbf{P}}$ e $\tau \mathbf{P}_{\mathbf{F P}}$, são as taxas médias de perda de energia acumuladas desde o ponto de conexão do cliente até a produção, na ponta e fora de ponta, respectivamente. 
$\mathbf{E}_{\mathrm{PS}}, \mathbf{E}_{\mathrm{PU}}, \mathbf{E}_{\mathrm{FS}}$ e $\mathbf{E}_{\mathrm{FU}}$, são os consumos do cliente na ponta e fora de ponta, nos períodos seco e úmido, respectivamente.

\subsection{Custo marginal de um cliente}

O custo marginal de um cliente compõe-se das parcelas de custos de potência e de energia.

- Custo marginal - Posto Ponta

$$
\begin{aligned}
& C_{m / P}=C_{E / P}+C_{T P}=C_{E / P S}+C_{E / P U}+C_{T P} \\
& \mathbf{C}_{\mathbf{m} / \mathbf{P}}=(1+\tau \mathbf{P} \mathbf{P}) \cdot\left(\tilde{\mu} \cdot \mathbf{P S} \cdot \mathbf{E}_{\mathbf{P S}}+\tilde{\mu} \cdot \mathbf{P U} \cdot \mathbf{E}_{\mathbf{P U}}\right)+\hat{\mu} \cdot \mathbf{P}_{\mathbf{P}}+\Sigma \delta_{n} \cdot \mathbf{P} \mathbf{n}_{\mathbf{P}}
\end{aligned}
$$

- Custo marginal - Posto Fora da Ponta

$$
\begin{aligned}
& C_{m / F P}=C_{E / F}+C_{T F P}=C_{E / F S}+C_{E / F U}+C_{\text {TFP }} \\
& \mathbf{C}_{\mathrm{m} / \mathrm{FP}}=\left(1+\tau \mathbf{P}_{\mathrm{FP}}\right) \cdot\left(\tilde{\mu} \cdot \mathrm{FS} \cdot \mathbf{E}_{\mathrm{FS}}+\tilde{\mu} \cdot \mathrm{FU} \cdot \mathbf{E}_{\mathrm{FU}}\right)+\hat{\mu} \cdot \mathbf{P}_{\mathrm{FP}}+\Sigma \delta_{n \cdot \mathbf{P n}}
\end{aligned}
$$

Assim sendo, o custo marginal total de um cliente é calculado pela seguinte expressão:

$$
\begin{aligned}
\mathbf{C}_{\mathrm{m} / \text { Total }}= & \mathbf{C}_{\mathrm{m} / \mathrm{P}}+\mathbf{C}_{\mathrm{m} / \mathrm{FP}, \text { ou }} \\
\mathbf{C}_{\mathrm{m} / \mathrm{Total}} & =\left(1+\tau \mathbf{P}_{\mathrm{P}}\right) \cdot\left(\tilde{\mu} \cdot \mathrm{PS} \cdot \mathbf{E}_{\mathrm{PS}}+\widetilde{\mu} \cdot \mathrm{PU} \cdot \mathbf{E}_{\mathrm{PU}}\right)+\hat{\mu} \cdot \mathbf{P}_{\mathrm{P}}+\Sigma \delta_{n} \cdot \mathbf{P} \mathbf{n}_{\mathrm{P}}+ \\
& +\left(1+\tau \mathbf{P}_{\mathrm{FP}}\right) \cdot\left(\tilde{\mu} \cdot \mathrm{FS} \mathbf{E}_{\mathrm{FS}}+\tilde{\mu} \cdot \mathrm{FU} \cdot \mathbf{E}_{\mathrm{FU}}\right)+\hat{\mu} \cdot \mathbf{P}_{\mathrm{FP}}+\Sigma \delta_{n} \cdot \mathbf{P} \mathbf{n}_{\mathrm{FP}}
\end{aligned}
$$

\section{CÁlCULO dOS CUSTOS MARGINAIS dA ILUMINAÇÃo PÚbLICA}

\subsection{Estimativas de participação das redes-tipos nas energias dos níveis MT e BT da clientela na energia das redes-tipo}

A partir da tipologia de carga de redes e clientes em nível Brasil, obtiveram-se as estimativas das tabelas B.1 e B.2. 
TABELA B.1 Participação das redes-tipo do nível MT na energia do nível e da clientela MT e BT na energia das redes-tipo.

\begin{tabular}{|c|c|c|c|c|c|}
\hline \multirow[t]{2}{*}{$\begin{array}{l}\text { REDE } \\
\text { TIPO }\end{array}$} & \multicolumn{2}{|c|}{$\begin{array}{l}\text { Participaçäo da Rede- } \\
\text { tipo na } \\
\text { Energia do Nivel }(\%) \\
\left(\alpha_{b}\right)\end{array}$} & \multicolumn{2}{|c|}{$\begin{array}{c}\text { Participaçăo da Clientela } \\
\text { MT e BT na Energia da } \\
\text { Rede Tipo }(\%) \\
\left(\beta_{h}\right)\end{array}$} & \multirow{2}{*}{$\begin{array}{l}\text { Horários de } \\
\text { Ponta da } \\
\text { Rede Tipo } \\
\text { (h) }\end{array}$} \\
\hline & $\begin{array}{l}\text { Postos } \\
\text { AT/MT }\end{array}$ & $\begin{array}{c}\text { Linhas } \\
\text { MT }\end{array}$ & $\begin{array}{c}\text { Clientes } \\
\text { MT }^{\star}\end{array}$ & $\begin{array}{c}\text { Clientes } \\
\text { BT* }\end{array}$ & \\
\hline 1 & 20 & 7 & 55 & 45 & $18 h-19 h$ \\
\hline 2 & 39 & 54 & 5 & 95 & $19 \mathrm{~h}$ \\
\hline 3 & 35 & 11 & 65 & 35 & $19 \mathrm{~h}$ \\
\hline 4 & 6 & 28 & 100 & 0 & $10 h-11 h-16 h$ \\
\hline
\end{tabular}

Fonte: DNAEE (1985).

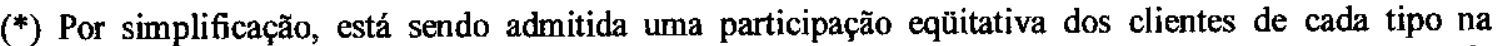
energia das diversas redes-tipo. A rigor, dever-se-ia ter a participação de cada cliente-tipo MT e de cada cliente-tipo BT. A clientela não residencial está incluída na estimativa de $\beta \mathrm{MT}$, e a residencial e iluminação pública na $\beta$ BT.

$\left(^{*}\right)$ Quando a ponta da rede-tipo tem probabilidade de ocorrer em mais de um horário, consideram-se esses horários equiprováveis.

TABELA B.2 Participação das redes-tipo do nível BT na energia do nível e da clientela BT na energia das redes-tipo.

\begin{tabular}{|c|c|c|c|c|}
\hline \multirow[t]{2}{*}{$\begin{array}{l}\text { REDE } \\
\text { TIPO }\end{array}$} & \multirow{2}{*}{\begin{tabular}{|c|}
$\begin{array}{c}\text { Participação da Rede- } \\
\text { tipo na } \\
\text { Energia do Nível}(\%) \\
\left(\alpha_{b}\right)\end{array}$ \\
Postos \\
MT/BT e \\
Rede BT
\end{tabular}} & \multicolumn{2}{|c|}{$\begin{array}{c}\text { Participaça da Clientela BT } \\
\text { na Energia da } \\
\text { Rede Tipo }(\%) \\
\left(\beta_{h}\right)\end{array}$} & \multirow{2}{*}{$\begin{array}{l}\text { Horários de } \\
\text { Ponta da } \\
\text { Rede Tipo } \\
\text { (h) }\end{array}$} \\
\hline & & Residencial* & $\begin{array}{c}\text { Não } \\
\text { residencial }\end{array}$ & \\
\hline 1 & 28 & 45 & 55 & $19 \mathrm{~h}$ \\
\hline 2 & 43 & 80 & 20 & $19 h-20 h$ \\
\hline 3 & 23 & 39 & 61 & $21 \mathrm{~h}-22 \mathrm{~h}$ \\
\hline 4 & 6 & 0 & 100 & $11 \mathrm{~h}-17 \mathrm{~h}$ \\
\hline
\end{tabular}

Fonte: DNAEE (1985).

(*) A participação da iluminação pública está incluída na estimativa de participação da BT residencial. 
3.2 Demandas da iluminação pública nos horários de ponta das redes do nível BT

A tabela B. 3 apresenta os valores de demanda $\left(\mathbf{P}_{\mathbf{h}}\right)$ da iluminação pública nos horários de ponta das redes de BT.

TABELA B.3 $\mathbf{P}_{\mathrm{h}}$ para a iluminação pública.

(Valores em \% da demanda máxima)

\begin{tabular}{|c|c|c|}
\hline Horks & $\begin{array}{l}\text { Demandes } \\
\text { (wh) }\end{array}$ & $\begin{array}{l}\text { (P) } \\
(\%)\end{array}$ \\
\hline 1 & 2.250 & \\
\hline 2 & 2.250 & \\
\hline 3 & 2.250 & \\
\hline 4 & 2.250 & \\
\hline 5 & 2.250 & \\
\hline 6 & 1.350 & \\
\hline 7 & & \\
\hline 8 & & \\
\hline 8 & - & \\
\hline$\overline{9}$ & - & \\
\hline $10(\mathrm{FP})$ & - & $\mathbf{0}$ \\
\hline 11 (FP) & - & $\mathbf{0}$ \\
\hline 12 & - & \\
\hline 13 & - & \\
\hline 14 & - & \\
\hline 15 & - & \\
\hline 16 (FP) & - & 0 \\
\hline 17 (P) & 450 & 20 \\
\hline 18 (P) & 1800 & 80 \\
\hline 19 (P) & 2.250 & 100 \\
\hline 20 (P) & 2.250 & 100 \\
\hline 21 (P) & 2.250 & 100 \\
\hline $22(P)$ & 2.250 & 100 \\
\hline 23 & 2.250 & \\
\hline 24 & 2.250 & \\
\hline bonstion & \\
\hline 701 & \multicolumn{2}{|c|}{$F$} \\
\hline Eromas & \multicolumn{2}{|c|}{100} \\
\hline FaT Tow Th & \multicolumn{2}{|c|}{70} \\
\hline
\end{tabular}

Nota: Os valores de demanda foram atualizados com base no consumo anual da iluminação pública registrado em 1998. 
3.2.1 Cálculo das probabilidades de associação da iluminação pública às redes-tipo, segundo os horários de ponta $\left(\pi_{h}\right)$

- Em relação ao nível MT/BT + BT

$$
\begin{aligned}
& \pi_{19 \mathrm{~h}}=\frac{0,28^{*} 0,45+0,43^{*} 0,80}{0,28^{*} 0,45+0,43^{*} 0,80+0,23^{*} 0,39+0,06^{*} 0}=\frac{0,298}{0,560}=53 \% \\
& \pi_{20 \mathrm{~h}}=\frac{0,5^{*} 0,43^{*} 0,80}{0,560}=\frac{0,172}{0,560}=31 \% \\
& \pi_{21 \mathrm{~h}}=\pi_{22 \mathrm{~h}}=\frac{0,5^{*} 0,23^{*} 0,39}{0,560}=\frac{0,045}{0,560}=8 \% \\
& \pi_{11 \mathrm{~h}}=\pi_{17 \mathrm{~h}}=\frac{0,5^{*} 0,06^{*} 0}{0,560}=0 \%
\end{aligned}
$$

- Em relação as linhas MT

$$
\begin{aligned}
& \pi_{18 \mathrm{~h}}=\frac{0,5^{*} 0,07+0,45}{0,07^{*} 0,45+0,54^{*} 0,95+0,11^{*} 0,35+0,28^{*} 0}=\frac{0,016}{0,583}=3 \% \\
& \pi_{19 \mathrm{~h}}=\frac{0,5^{*} 0,07 * 0,45+0,54 * 0,95+0,11^{*} 0,35}{0,583}=\frac{0,5675}{0,583}=97 \% \\
& \pi_{10 \mathrm{~h}}=\pi_{11 \mathrm{~h}}=\pi_{16 \mathrm{~h}}=0 \%
\end{aligned}
$$

- Em relação aos postos AT/MT

$$
\begin{aligned}
& \pi_{18 \mathrm{~h}}=\frac{0,5^{*} 0,20 * 0,45}{0,20^{*} 0,45+0,39 * 0,95+0,35^{*} 0,35+0,06 * 0}=\frac{0,045}{0,583}=8 \% \\
& \pi_{19 \mathrm{~h}}=\frac{0,5^{*} 0,20 * 0,45+0,39 * 0,95+0,35^{*} 0,35}{0,583}=\frac{0,5375}{0,583}=92 \% \\
& \pi_{10 \mathrm{~h}}=\pi_{11 \mathrm{~h}}=\pi_{16 \mathrm{~h}}=0 \%
\end{aligned}
$$


Os valores de probabilidades $\pi_{\mathbf{h}}$ para iluminação pública apresentados na tabela B.4, sãos os mesmos dos clientes BT residenciais, considerando que os sistemas de IP estão conectados predominantemente nas redes deste nível.

TABELA B.4 $\pi_{\mathrm{h}}$ da IP para todos os níveis.

\begin{tabular}{|c|c|c|c|c|c|c|c|c|c|}
\hline \multirow{2}{*}{$\begin{array}{c}\text { Nível } \\
\text { Tarifário ou } \\
\text { de rede }\end{array}$} & \multicolumn{8}{|c|}{ Horários de Ponta das Redes-Tipo do Nível } \\
\cline { 2 - 9 } & $\mathbf{1 7 h}$ & $\mathbf{1 8 h}$ & $\mathbf{1 9 h}$ & $\mathbf{2 0 h}$ & $\mathbf{2 1 h}$ & $\mathbf{2 2 h}$ & $\mathbf{1 0 h}$ & $\mathbf{1 1 h}$ & $\mathbf{1 6 h}$ \\
\hline $\mathbf{A 0}$ & - & $5 \%$ & $90 \%$ & - & - & - & \multicolumn{3}{|c|}{$5 \%$} \\
\hline $\mathbf{A 1}$ & - & $5 \%$ & $90 \%$ & - & - & - & \multicolumn{3}{|c|}{$5 \%$} \\
\hline $\mathbf{A 2}$ e A3 & - & $5 \%$ & $90 \%$ & - & - & - & \multicolumn{3}{|c|}{$5 \%$} \\
\hline $\mathbf{A T} / \mathbf{M T}$ & - & $\mathbf{8 \%}$ & $\mathbf{9 2 \%}$ & - & - & - & $\mathbf{0} \%$ & $0 \%$ & $0 \%$ \\
\hline MT & - & $3 \%$ & $97 \%$ & - & - & - & $0 \%$ & $0 \%$ & $0 \%$ \\
\hline MT/BT+BT & $0 \%$ & - & $53 \%$ & $31 \%$ & $\mathbf{8} \%$ & $\mathbf{8} \%$ & - & $0 \%$ & - \\
\hline
\end{tabular}

Fonte: DNAEE (1985).

Notas: $\mathrm{O} \pi_{\mathrm{h}}$ da iluminação pública é o mesmo para o cliente BT residencial.

Os valores de $\pi_{\mathrm{b}}$ relativos às redes a montante do nivel AT/MT foram estimados.

\subsection{Cálculo das responsabilidades da iluminação pública}

A partir dos parâmetros apresentados nos quadros 1, 2 e 3 e utilizando a equação A.1, é possível calcular a responsabilidade da IP nos diversos níveis do sistema elétrico.

A tabela B.5 apresenta as taxas médias de perdas de potência e energia, acumuladas desde o nível de BT até o nível de responsabilidade considerado.

TABELA B.5 Perdas acumuladas a partir dos pontos de conexão no nível BT.

\begin{tabular}{|c|c|c|c|c|}
\hline \multirow{3}{*}{ NivEL } & \multicolumn{4}{|c|}{ Fatores de Perdas } \\
\cline { 2 - 5 } & \multicolumn{2}{|c|}{ Potência } & \multicolumn{2}{c|}{ Energia } \\
\cline { 2 - 5 } & Ponta & F. de Ponta & Ponta & F. de Ponta \\
\cline { 2 - 5 } & $\left(1+\tau_{\mathrm{P}}\right)$ & $\left(1+\tau_{\mathrm{FP}}\right)$ & $\left(1+\tau_{\mathrm{P}}\right)$ & $\left(1+\tau_{\mathrm{FP}}\right)$ \\
\hline MT/BT+BT & 1,08 & 1,05 & 1,08 & 1,05 \\
\hline Linhas MT & 1,13 & 1,09 & 1,14 & 1,09 \\
\hline $\mathbf{A T} / \mathbf{M T}$ & 1,13 & 1,09 & 1,14 & 1,09 \\
\hline $\mathbf{A 2} \mathbf{e} \mathbf{A 3}$ & 1,22 & 1,14 & 1,21 & 1,14 \\
\hline $\mathbf{A 1}$ & 1,23 & 1,15 & 1,23 & 1,15 \\
\hline $\mathbf{A 0}$ & 1,27 & 1,17 & 1,26 & 1,17 \\
\hline
\end{tabular}

Fonte: DNAEE (1985, p.258). 
De acordo com a expressão B.2 tem-se:

- Responsabilidade de potência no posto ponta

$P_{P}=\left(1+\tau_{P}\right) \cdot\left(\pi_{17 h} P_{17 h}+\pi_{18 h} P_{18 h}+\pi_{19 h} P_{19 h}+\pi_{20 h} P_{20 h}+\pi_{21 h} P_{21 h}+\pi_{22 h} P_{22 h}\right)$

- Responsabilidade de potência no posto fora de ponta

$P_{\mathrm{FP}}=\left(1+\tau_{\mathrm{FP}}\right) \cdot\left(\pi_{10 \mathrm{~h}} \mathbf{P}_{10 \mathrm{~h}}+\pi_{11 \mathrm{~h}} \mathbf{P}_{11 \mathrm{~h}}+\pi_{16 \mathrm{~h} .} \mathbf{P}_{16 \mathrm{~h}}\right)$

\section{Cálculos}

- Em relação nível MT/BT + BT

$$
\begin{aligned}
P_{P} & =1,08 .(0 \times 20+0 \times 80+0,53 \times 100+0,31 \times 100+0,08 \times 100+0,08 \times 100) \\
& =1,08(53+31+8+8)=1,08 \times 100=108,0
\end{aligned}
$$

\section{- Em relação ao nível linhas MT}

$P_{P}=1,13 .(0,03 \times 80+0,97 \times 100$

$$
=1,13(2,4+97)=1,13 \times 99,4=112,5
$$

\section{- Em relação ao nível AT/MT}

$P_{P}=1,13 .(0,08 \times 80+0,92 \times 100)$

$=1,13(6,4+92)=1,13 \times 98,4=111,0$

- Em relação ao nível A2 e $\mathbf{A 3}$

$\mathrm{P}_{\mathrm{P}}=1,22 .(0,05 \times 80+0,9 \times 100)$

$=1,22(4+90)=1,22 \times 94=115,0$

- Em relação ao nível A1

$$
\begin{aligned}
P_{P} & =1,23 .(0,05 \times 80+0,9 \times 100) \\
& =1,23(4+90)=1,23 \times 94=116,0
\end{aligned}
$$

- Em relação ao nível A0 e Produção

$$
P_{P}=1,27 .(0,05 \times 80+0,9 \times 100)=1,27 \times 94=\mathbf{1 1 9 , 5}
$$


TABELA B.6 Responsabilidade de potência da IP (\%).

\begin{tabular}{|c|c|c|c|c|c|c|c|}
\hline Cliente & \multicolumn{7}{|c|}{ NíVEL } \\
\cline { 2 - 8 } Tipo & MT/BT+BT & Linhas MT & ATT/MT & A2+A3 & A1 & AO & Prod. \\
\hline IP & 108,0 & 112,5 & 111,0 & 115,0 & 116,0 & 119,5 & 119,5 \\
\hline
\end{tabular}

Nota: A iluminação pública não tem responsabilidade de potência nos horários fora de ponta.

\subsection{Custos marginais do sistema}

TABELA B.7 Custo marginais de produção e de redes (R\$)*.

\begin{tabular}{|c|c|c|c|c|c|}
\hline \multirow{2}{*}{ NÍVEL } & \multirow{2}{*}{$\begin{array}{l}\text { POTÊNCIA } \\
\text { RS/kW.ano }\end{array}$} & \multicolumn{4}{|c|}{ ENERGIA (RS/MWh) } \\
\cline { 3 - 6 } & & \multicolumn{4}{|c|}{ POSTO TARIFÁRIO } \\
\cline { 3 - 6 } & & PONTA & SECA & ÚMIDA & SERA DE PONTA \\
\hline PRODUÇÃO & 25,00 & 47,91 & 41,23 & 40,34 & 34,7 \\
\hline AO & 29,50 & 2,02 & 2,02 & 0,77 & 0,77 \\
\hline A1 & 34,52 & - & - & - & - \\
\hline A2+ A3 & 75,60 & - & - & - & - \\
\hline AT/MT & 5,93 & - & - & - & - \\
\hline Linhas MT & 21,33 & - & - & - & - \\
\hline MT/BT + BT & 38,31 & & - & - & - \\
\hline
\end{tabular}

*Estimado com base nos valores da COELBA (1996).

\subsection{Cálculo dos custos de capacidade}

Os custos de capacidade da iluminação pública, em relação a cada nível (produção, níveis tarifários e niveis de rede), serão calculados utilizando-se as expressões B.1 e B.2, de acordo com as responsabilidades de potência constantes do quadro 6 e os custos marginais apresentados na tabela B.7.

- Em relação ao nível de Produção:

$$
\mathbf{C}_{\mathbf{P}}=25 \times 1,195=29,87 \mathrm{R} \$ / \mathrm{kW} \text {.ano }
$$

- Em relação ao nível A0:

$$
\mathbf{C}_{\mathbf{P}}=29,50 \times 1,195=35,25 \mathrm{R} \$ / \mathrm{kW} . \mathrm{ano}
$$

- Em relação ao nível A1:

$$
\mathbf{C}_{\mathbf{P}}=34,52 \times 1,16=3,65 \mathrm{R} \$ / \mathrm{kW} \text {.ano }
$$


- Em relação ao nível $\mathbf{A 2}+\mathbf{A 3}$ :

$$
\mathrm{C}_{\mathbf{P}}=40 \times 1,15=40,00 \mathrm{R} \$ / \mathrm{kW} \text {.ano }
$$

- Em relação ao nível AT/MT

$$
\mathbf{C}_{\mathbf{P}}=5,93 \times 1,11=6,58 \mathrm{R} \$ / \mathrm{kW} \text {.ano }
$$

- Em relação ao nível linhas MT

$$
\mathbf{C}_{\mathbf{P}}=21,33 \times 1,125=24,00 \mathrm{R} \$ / \mathrm{kW} \text {.ano }
$$

- Em relação ao nível linhas $\mathrm{MT} / \mathrm{BT}+\mathrm{BT}$

\begin{tabular}{|c|c|c|}
\hline \multirow{2}{*}{ Nool } & \multicolumn{2}{|c|}{ DHontor } \\
\hline & POII & Holo \\
\hline 190 & 29,87 & 0 \\
\hline 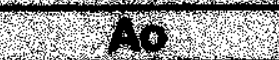 & 35,25 & 0 \\
\hline Sth & 40,00 & 0 \\
\hline Novis & 86,94 & 0 \\
\hline 10 & 6,58 & 0 \\
\hline  & 24,00 & 0 \\
\hline WIISW & 42,45 & 0 \\
\hline (o) & 265,1 & 0 \\
\hline
\end{tabular}

$$
C_{\mathbf{P}}=39,31 \times 1,08=41,37 \mathrm{R} \$ / \mathrm{kW} \text {.ano }
$$

TABELA B.8 Custos de capacidade da IP (R\$/kW.ano).

\begin{tabular}{|c|c|c|c|c|c|c|c|c|}
\hline Alente & $\begin{array}{l}\text { Por seos } \\
\text { CE. }\end{array}$ & 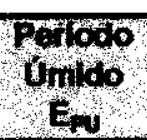 & Total & $\begin{array}{c}\text { Petwo } \\
\text { S, } 00 \\
E_{* j}\end{array}$ & Omis & Total & $\begin{array}{l}\text { Consmo } \\
\text { Tota' }\end{array}$ & $\begin{array}{l}\text { Domenda } \\
\text { Woine } \\
\text { (Winh) }\end{array}$ \\
\hline IP & $1.184,30$ & 789,50 & $1.973,80$ & $4.638,40$ & $3.256,80$ & $7.895,20$ & 9.689 & 2.250 \\
\hline
\end{tabular}

Fonte: ELETROBRÁS, 1998.

3.6 Cálculo dos custos de energia

TABELA B.9 Mercado de energia da iluminação pública*

* Consumo total registrado em 1998 e consumo de cada período estimado com base nos percentuais adotados pelo DNAEE (1985). 
a) Posto Ponta - periodo seco: PS

$\mathbf{C}_{\mathrm{E} / \mathrm{PS}}=\tilde{\mu} \cdot \mathbf{P S} \cdot\left(\mathbf{1}+\tau \mathbf{P}_{\mathrm{P}}\right) \cdot \mathbf{E}_{\mathrm{PS}}$

$=\frac{1,26 *(47,91+2,02) * 1.184,3}{2.250}=\frac{1,26 * 49,93 * 1.184,3}{2.250}=\frac{74.506,4}{2.250}=\mathbf{3 3 , 1 1}$

b) Posto Ponta - período úmido: PU

$$
\begin{gathered}
\mathrm{C}_{\mathrm{E} / \mathrm{PU}}=\tilde{\mu} \cdot \mathrm{PU} \cdot\left(1+\tau \mathrm{P}_{\mathrm{P}}\right) \cdot \mathrm{E}_{\mathrm{PU}} \\
=\frac{1,26 *(41,23+2,02)^{\star} 789,5}{2.250}=\frac{1,26 * 43,25 * 789,5}{2.250}=\frac{43.023,8}{2.250}=19,13
\end{gathered}
$$

- Total ponta:

$$
\tilde{\mu} \cdot \mathrm{p}=\tilde{\mu} \cdot \mathrm{PS}+\tilde{\mu} \cdot \mathrm{pU}=33,11+19,13=52,25
$$

c) Posto Fora de Ponta - período seco: FS

$$
\begin{gathered}
\mathbf{C}_{\mathrm{E} / \mathrm{FS}}=\tilde{\mu}_{\mathrm{FFS}} \cdot\left(1+\tau \mathrm{P}_{\mathrm{FP}}\right) . \mathbf{E}_{\mathrm{FS}} \\
=\frac{1,17^{*}(\mathbf{4 0 , 3 4}+0,77)^{*} 4.638,4}{2.250}=\frac{1,17^{*} 41,11^{*} 4.638,4}{2.250}=\frac{223.101}{2.250}=99,15
\end{gathered}
$$

- Posto Fora de Ponta - período úmido: FU

$$
\begin{aligned}
& \mathbf{C}_{\mathrm{E} / \mathrm{FU}}=\tilde{\mu} \cdot \mathrm{FU} \cdot\left(1+\tau \mathbf{P}_{\mathrm{FP}}\right) \cdot \mathbf{E}_{\mathrm{FU}} \\
& =\frac{1,17^{*}(34,7+0,77) * 3.256,8}{2.250}=\frac{1,17 * 35,47 * 3.256,8}{2.250}=\frac{135.157}{2.250}=\mathbf{6 0 , 1}
\end{aligned}
$$

- Total fora de ponta

$$
\widetilde{\mu}_{. F S}=\widetilde{\mu}_{. F S}+\tilde{\mu}_{. F U}=99,15+60,1=159,3
$$




\section{Custo marginal (R\$/kW.ano)}

- $\quad$ Total ponta: $265,1+52,25=\mathbf{3 1 7 , 3 5}$

- Total fora da ponta: $0+159,3=\mathbf{1 5 9 , 3}$

\section{Custo marginal (RS/MWh)}

- Ponta $=\frac{317,35^{*} 2.250}{1.973,8}=361,75 \mathrm{R} \$ / \mathrm{kW}$. ano

- F. Ponta $=\frac{159,3^{*} 2.250}{7.895,2}=45,4 \mathrm{R} \$ / \mathrm{kW}$.ano

\section{Custo marginal total (RS/MWh)}

$$
\frac{(361,75 * 1.973,8+45,4 * 7.895,5)}{9.869}=\frac{714.022,15+358.455,7}{9.869}=108,67 \mathrm{R} \$ / \mathrm{MWh}
$$

- Na ponta: 72,35 R\$/MWh

- F. ponta: 36,32 R\$/MWh 


\section{APÊNDICE C GESTÃo DE SISTEMAS DE ILUMINAÇÃo PÚBLICA*}

Todo sistema de iluminação pública está sujeito a desgastes contínuos devido a sua exposição às intempéries do ambiente externo e, eventualmente, a fatores atribuídos ao próprio homem, como por exemplo, acidentes de trânsito e vandalismo. A gestão eficiente, incluindo as atividades de planejamento, projeto, manutenção e controle de custos, é importante para assegurar a qualidade do sistema de iluminação pública, com mínimo custo e máxima utilização dos equipamentos.

\section{CADASTRO DO SISTEMA DE IP}

O cadastro do sistema de iluminação pública é fundamental para execução das atividades de manutenção e o faturamento do consumo de energia elétrica pela concessionária. $O$ cadastro deve conter a indicação dos principais componentes da iluminação e as informações necessárias ao gerenciamento do sistema. O grau de detalhamento e a metodologia de atualização devem ser definidos, conjuntamente, entre a prefeitura municipal e a concessionária de energia elétrica.

\section{PRINCIPAIS FATORES A SEREM CONSIDERADOS NA ELABORAÇÃO DE UM PROGRAMA DE MANUTENÇÃO}

A elaboração de programas de manutenção num sistema de IP é afetado por diversos fatores, principalmente:

a) queima de lâmpadas devido ao final de sua vida útil, falhas no circuito elétrico de distribuição de energia, acidentes e vandalismo;

b) depreciação do fluxo luminoso da lâmpada devido ao seu envelhecimento natural;

c) depreciação da luminária devido ao acúmulo de sujeira no refletor, refrator e na lâmpada, $\mathrm{e}$ interferência da arborização;

\section{a) Vida da lâmpada}

Nem todos os fabricantes adotam o mesmo critério para indicação do tempo de vida de lâmpadas - cujos valores são determinados em laboratório, sob condições elétricas, térmicas e mecânicas específicas - o que deve ser consultado nos seus catálogos técnicos. Ao final de suas vidas, as lâmpadas podem apresentar apagamentos intermitentes, sendo necessário sua substituição sob pena de queima dos equipamentos auxiliares. Os principais fatores que afetam o desempenho das lâmpadas de descarga são:

$\Rightarrow$ má instalação (por exemplo: inversão de polaridade em lâmpadas VSAP);

$\Rightarrow$ vibração excessiva;

$\Rightarrow$ luminária inadequada;

$\Rightarrow$ características do reator;

$\Rightarrow$ qualidade da tensão da rede de distribuição;

$\Rightarrow$ partidas (quanto maior, menor será a expectativa de vida lâmpada).

* Fonte: BARBOSA ; ALMEIDA (1998). 
Em locais onde exista a freqüente destruição de lâmpadas por vandalismo, é recomendado a utilização de luminárias com refrator em policarbonato estabilizado contra os raios ultravioleta. Esses refratores possuem elevada resistência mecânica à impactos, protegendo a luminária $\mathrm{e}$ evitando a quebra da lâmpada.

\section{a) Depreciação do fluxo luminoso da lâmpada}

Durante sua vida o fluxo luminoso de uma lâmpada diminui gradualmente. Essa característica geralmente é representada em termos percentuais a partir de um certo número de horas de funcionamento diário, através da curva de depreciação do fluxo luminoso. A não substituição de uma lâmpada com baixo fluxo luminoso, além de consumir praticamente a mesma quantidade de energia elétrica de uma lâmpada nova, reduz os níveis de iluminação projetados para um logradouro. Para evitar tal situação, é importante registrar as datas de instalação da lâmpada e das manutenções realizadas, visando programar sua substituição após a vida útil.

\section{b) Depreciação da luminária}

Além da depreciação natural do fluxo luminoso da lâmpada, a sujeira que se acumula externa $\mathrm{e}$ internamente numa luminária pode causar uma redução total do fluxo luminoso emitido. A limpeza de refratores e refletores é portanto um fator importante a ser considerado num processo de manutenção. Em regiões com grande incidência de poeira, poluição ou outros agentes agressivos, devem ser programadas constantes limpezas.

Como regra geral, sugere-se que sempre que se faça a substituição de uma lâmpada, também seja efetuada a limpeza da luminária e seu refrator. Esse tempo, na prática, representa um período entre limpezas variando de 3 a 4 anos. Entretanto, para ambientes com elevado índice de poluição, como zonas industriais ou áreas centrais de grandes cidades, recomenda-se que a limpeza seja feita anualmente.

Dependendo do tipo de material do refrator, existem vários métodos a serem empregados.

- Para refratores de vidro, por exemplo, pode ser utilizado água e sabão, ou fluidos limpadores de vidros.

- Para limpeza de refratores plásticos, sugere-se contactar o fabricante para obter informações sobre o processo adequado para sua limpeza. No caso de refratores de policarbonato, recomendando-se sua substituição a cada 4 anos, pois possuem baixa resistência aos raios ultravioletas, que causam o seu amarelamento, podendo reduzir precocemente a sua transmitância.

Já os refletores, que são equipamentos metálicos, podem ser severamente atacados por produtos que contenham substâncias abrasivas, como por exemplo amônia. Nesse caso, a maneira mais simples de limpá-los é borrifar uma solução não abrasiva sob sua superfície e secar com uma flanela. Esse processo é demorado, porém eficaz.

\section{c) Obstrução das luminária pela arborização}

Galhos de árvores e folhagens provocam sombras nas ruas, constituindo-se num constante problema para a iluminação pública. Em muitos casos, as árvores cobrem totalmente as luminárias, causando o escurecimento da via e o desperdício de energia elétrica. Assim, são recomendadas podas periódicas que, além de auxiliarem no desempenho adequado da IP, são fundamentais para garantir o crescimento das árvores. 
Recomenda-se também que as equipes de manutenção trabalhem em consonância com os órgãos municipais responsáveis pela arborização, visando garantir os níveis mínimos de visibilidade com o menor número de árvores cortadas possível. Cabe às equipes responsáveis pela manutenção da iluminação pública orientar esses órgãos quanto a necessidade de podas preventivas e quanto aos tipos mais adequados de árvores a serem plantadas.

\section{CRITÉRIOS E PROCEDIMENTOS PARA GERENCIAMENTO DO SISTEMA DE IP}

\section{a) Manutenção Corretiva}

A manutenção corretiva é o serviço realizado com o objetivo de reparar os defeitos ocorridos no sistema de iluminação pública. É importante não só a correção das falhas, mas a identificação de suas causas, a fim de que medidas preventivas possam ser adotadas para minimizar as ocorrências e para mobilizar os recursos de forma planejada.

Geralmente, dois métodos são adotados com a finalidade de identificar e levantar os pontos defeituosos do sistema de iluminação pública:

- Inspecão Prévia - é adotada nos casos de áreas que apresentam menor ocorrência de falhas, permitindo o estabelecimento de um programa de manutenção com roteiro definido e otimizado, de modo a reduzir custos.

- Ronda Periódica - é uma inspeção visando corrigir imediatamente os defeitos encontrados.

- A Inspeção Prévia deve ser realizada segundo uma programação definida, caso em que as equipes terão mais tempo e melhores condições para observarem a situação das instalações, além de lâmpadas apagadas nos períodos noturnos e acesas no período diurno. Os roteiros devem ser priorizados de acordo com a importância das vias e demais logradouros públicos.

A Ronda Periódica é realizada, prioritariamente, em áreas onde os defeitos ocorrem com maior freqüência, devendo a equipe de manutenção dispor de estoque de material necessário e suficiente para a correção dos pontos de iluminação defeituosos encontrados. As falhas que por algum motivo não possam ser corrigidas, devem ser anotadas no formulário de inspeção para posterior programação.

\section{b) Manutenção Preventiva}

O objetivo da manutenção preventiva é o de evitar e/ou minimizar a ocorrência de falhas e reclamações dos usuários, mantendo o sistema de iluminação pública funcionando continuamente e com a melhor qualidade possível. Para atingir esse objetivo, um método adotado é o da "reposição coletiva de lâmpadas". Nesse método, torna-se indispensável o conhecimento do tempo vida útil das lâmpadas (e demais equipamentos de IP) na rede de distribuição, e um controle efetivo da data e local de instalação das mesmas. Considerando que as informações fornecidas pelos fabricantes são determinadas a partir de condições especificadas em laboratório, é de se esperar os valores verificados em campo sejam diferentes.

Em determinadas instalações, a troca de todas as lâmpadas entre $75 \%$ e $85 \%$ do tempo de vida útil se constitui num critério aceitável, levando em consideração também, a depreciação do fluxo luminoso. Outro critério pode ser a substituição de todas as lâmpadas de uma área, quando, por exemplo, $20 \%$ do total falharem prematuramente. Vale ressaltar que para adoção desse método é necessário que todas as lâmpadas da área controlada tenham sido instaladas numa mesma data. 


\section{c) Gerenciamento e Controle dos Serviços de Manutenção}

A avaliação e o controle dos serviços das equipes de manutenção do sistema de IP, podem ser realizados através de dois procedimentos. Primeiro, a observação, "em campo", do desempenho das equipes, inclusive com a medição do tempo de execução de cada serviço. Segundo, através da análise e avaliação dos formulários preenchidos pelas equipes, verificando-se todas as informações sobre os serviços executados, tipo e quantidade de material empregado e/ou retirado do sistema, tempo gasto, etc.

\section{d) Controle de Qualidade do Material Utilizado}

A performance ou desempenho de um sistema de iluminação pública, depende de sua concepção, construção e, principalmente, da qualidade de cada componente utilizado: conectores, luminárias, lâmpadas e reatores, inclusive da qualidade de tensão da rede de distribuição de energia elétrica da concessionária.

Recomenda-se padronizar e normatizar os materiais utilizados de acordo com as normas técnicas da ABNT ou, na falta delas, normas internacionais. $O$ objetivo é, através da utilização das especificações técnicas, assegurar desde a etapa de projeto um serviço de qualidade. Esses procedimentos, além de favorecerem as atividades de manutenção do sistema de iluminação pública, podem otimizar os processos de compra e gerenciamento de estoque.

\section{e) Acompanhamento de Custos}

O controle e avaliação dos custos de manutenção do sistema de IP é fundamental para o planejamento dos dispêndios anuais com essa atividade e para auxiliar nas negociações e/ou encontro de contas entre a prefeitura e a empresa responsável pela execução dos serviços de manutenção. Sempre que possível, todos os custos devem ser contabilizados por item de serviço. Por exemplo:

- material e equipamentos;

- mão-de-obra;

- manutenção preventiva e corretiva;

- administração e fiscalização;

- atendimento ao usuário;

- atualização do cadastro.

\section{ATENDIMENTO AO USUÁRIO}

Os critérios e procedimentos adotados para atendimento às reclamações dos usuários com relação aos defeitos no sistema de iluminação pública podem variar de acordo com o órgão responsável por esse serviço: prefeitura ou concessionária. Entretanto, na maioria dos casos, concessionárias e prefeituras adotam o sistema de recebimento das reclamações através de mesas telefônicas automatizadas, semelhante ao atendimento de falhas na rede de distribuição (Plantão 196). Esse sistema permite o atendimento às reclamações, com anotações das informações e a gravação das conversas realizadas.

Todos os reparos solicitados são registrados em formulários apropriados contendo, basicamente, endereço do local da falha, dia e hora da reclamação e nome do reclamante. $O$ pessoal envolvido nesse serviço deve ser treinado para: adequado atendimento ao usuário, obtenção de dados precisos sobre as ocorrências e o preenchimento correto dos formulários. As reclamações 
recebidas devem ser analisadas e priorizadas de acordo com a ordem de recebimento e/ou grau de importância.

Tratando-se de um serviço essencial à população, deve-se procurar efetuar os reparos com eficiência e rapidez, através de uma programação adequada dos serviços. Nos casos de riscos para segurança de pessoas e instalações, o atendimento deve ser emergencial, ou seja, no menor espaço de tempo possível. Recomenda-se que o tempo gasto entre a reclamação do consumidor e a correção de um defeito não seja maior que 1 (um) dia.

\section{RELATÓRIOS GERENCIAIS}

Os relatórios de acompanhamento dos procedimentos e atividades de manutenção são instrumentos de apoio necessários ao gerenciamento do sistema de IP, principalmente no que se refere à qualidade dos materiais e equipamentos, custos envolvidos e atendimento ao usuário. A título de sugestão, recomenda-se emitir os seguintes:

\section{a) Acompanhamento de Carga da IP}

Visa atualizar o cadastro do sistema de iluminação pública, incorporando as alterações de carga, mudanças nos tipos de equipamentos e outras informações necessárias, possibilitando também o cálculo do valor do consumo de energia elétrica para fins de faturamento da concessionária.

\section{b) Atendimento ao Usuário}

Visa o acompanhamento e a avaliação dos atendimentos às reclamações dos usuários. Deve conter, basicamente, as seguintes informações:

- reclamações recebidas, canceladas, pendentes e atendidas;

- freqüência média de reclamações: diária, mensal e anual;

- tempo médio de atendimento às reclamações.

\section{c) Serviços Executados na IP}

Visa acompanhar a qualidade dos serviços e deve conter as seguintes informações básicas:

- Tipos de defeitos mais freqüentes: por zona, núcleo administrativo ou escritório regional;

- Principais causas de defeitos na IP;

- Tipo e quantidade de equipamentos substituídos;

- Tipo e quantidade de equipamentos e materiais aplicados.

\section{d) Custos da Manutenção do Sistema de IP}

Visa analisar a evolução dos custos de manutenção do sistema de IP, devendo conter, basicamente, os seguintes itens:

- Custos de materiais e equipamentos;

- Custos de mão-de-obra para manutenção (contratada + própria);

- Custos de transporte (manutenção de veículos + licenciamento + combustível);

- Custos de atendimento ao usuário. 


\section{PLANO DIRETOR DE ILUMINAÇÃO PÚBLICA}

O Plano Diretor de Iluminação Pública - PDIP, é o conjunto de diretrizes e normas destinado a orientar as atividades de implantação e expansão do sistema de iluminação pública do Município. O PDIP deve estabelecer também, os critérios básicos a serem observados na elaboração de projetos, levando em consideração conceitos de luminotécnica, peculiaridades locais - a exemplo da arborização existente na cidade -, e sobretudo, a introdução dos princípios de eficiência energética e o combate ao desperdício de energia elétrica.

É através do PDIP que torna-se possível o planejamento a longo prazo desse sistema e dos serviços a ele inerentes, em consonância com o Plano Diretor de Desenvolvimento Municipal, que é obrigatório para os Municípios com população superior a 20.000 habitantes. O PDIP deve ser revisto periodicamente para atender a dinâmica de crescimento da cidade, a evolução tecnológica e as tendências do mercado.

\section{a) Objetivos Gerais do PDIP}

- Estabelecer diretrizes para implantação de um serviço de IP moderno, eficiente e econômico, permitindo a melhoria do bem-estar da população;

- Orientar o planejamento do sistema de IP, visando a abrangência espacial dos serviços à toda população;

- Promover o uso racional e eficiente da energia elétrica na IP, contribuindo para minimizar os impactos ambientais;

- Compatibilizar e integrar as ações de iluminação pública com o Plano de Desenvolvimento Municipal

\section{b) Objetivos Específicos do PDIP}

- Estabelecer normas e padrões de equipamentos e materiais utilizados na IP.

- Definir critérios técnicos e econômicos para a elaboração de projetos, visando garantir o conforto visual de pedestres e motoristas.

- Propor sistemas especiais de IP nas áreas densamente arborizadas, com o objetivo de preservar as áreas verdes da cidade.

- Estabelecer normas gerais para a prestação dos serviços de IP, visando assegurar a sua qualidade.

- Definir o programa plurianual de investimentos no sistema de IP, incluindo-o no Orçamento Geral do Município.

\section{RECOMENDAÇÕES PARA MANUTENÇÃo EFICIENTE DO SISTEMA DE IP}

a) Elaborar o cadastro do sistema de iluminação pública, identificando os seguintes pontos:

- Propriedade das instalações; 
- Zona, localização e classificação das vias de acordo com sua importância para o tráfego de veículos e de pedestres, para o comércio, o lazer, etc.;

- Quantidade de lâmpadas de acordo com tipo e potência;

- Características e tipos de equipamentos utilizados: lâmpadas, luminárias, braços, reatores, relés, etc., inclusive datas de instalação;

- Tipos de comando e controle do sistema: individual, em grupo, temporizado;

- Transformadores de distribuição: exclusivo para IP ou comum à rede de distribuição da concessionária;

- Disposição das luminárias;

- Espaçamento, altura das estruturas e altura de montagem das luminárias;

- Nivel de tensão da rede de distribuição;

- Condições gerais das instalações.

b) Elaborar contrato de fornecimento entre a Prefeitura Municipal e a concessionária de energia elétrica, estabelecendo critérios e procedimentos a serem observados nos serviços de iluminação pública.

c) Definir, conjuntamente, prefeitura e concessionária, a sistemática para atualização do cadastro de modo que as alterações no sistema de IP, (expansão, ampliação de potência, reforma, etc.), sejam de conhecimento prévio das partes.

d) Implantar e manter atualizado um banco de dados sobre o sistema de iluminação pública, constando, basicamente, das seguintes informações:

- Consumo mensal de energia elétrica por sistema, e respectivo valor da conta de energia elétrica;

- Gastos com lâmpadas e demais equipamentos;

- Gastos com mão-de-obra;

- Custos de expansão do sistema de IP;

- Custos de operação e manutenção.

e) Padronizar e normatizar os tipos de lâmpadas e demais equipamentos utilizados no sistema de IP.

f) Verificar os níveis de tensão da rede de distribuição que atendem ao sistema de IP.

g) Acompanhar o tempo de vida útil dos equipamentos, confrontando-o com os dados fornecidos pelos fabricantes.

h) Implantar sistema de controle de qualidade de materiais e equipamentos, exigindo dos fabricantes a comprovação das informações técnicas dos seus produtos através de entidades oficialmente credenciadas.

i) Implementar programas de redução de custos e melhoria da eficiência energética do sistema de iluminação pública, com a implantação de equipamentos eficientes.

j) Treinar e capacitar o pessoal envolvido nos serviços. 


\title{
APÊNDICE D PROPOSTAS DE EMENDA À CONSTITUIÇÃO FEDERAL E DE PROJETOS DE LEI COMPLEMENTAR SOBRE A TIP
}

\author{
PROPOSTA DE EMENDA À CONSTITUIÇÃO - 175 - A
}

(Do Sr. José Carlos Aleluia)

Art. 155

Parágrafo $3^{\circ}$ - À exceção dos impostos de que tratam o inciso II do caput deste artigo, o art. 153, I e II, e o inciso II do parágrafo $3^{\circ}$ do art. 156, nenhum outro tributo poderá incidir sobre operações relativas a energia elétrica, serviços de telecomunicações, derivados de petróleo, combustíveis e minerais do País.

Art. 156

Parágrafo $3^{\circ}$

III - estabelecer normas para determinação do fato gerador, base de cálculo e contribuintes do imposto sobre serviço de iluminação pública.

Proposta de Emenda à Constituição - 175A

Art. 145

Parágrafo $3^{\circ}$ - As taxas pela utilização dos serviços de coleta de lixo e de iluminação pública terão a respectiva base de cálculo fixada de modo equivalente aso custo total da prestação dos serviços dividido pelos usuários na forma da lei.

Art. 155

Parágrafo $3^{\circ}$ - À exceção dos impostos de que tratam o inciso II do caput deste artigo, o artigo 153 , I e II, e as taxas de que trata o $\S 3^{\circ}$ do artigo 145 , nenhum outro tributo poderá incidir sobre operações relativas a energia elétrica, serviços de telecomunicações, derivados de petróleo, combustiveis e minerais do País. 


\section{PROJETO DE LEI COMPLEMENTAR n 194, DE 1997 \\ (Do Sr. Albérico Filho)}

Estabelece normas que disciplina a criação, pelos municípios, da taxa de iluminação pública e dá outras providências.

\section{(APENSE-SE AO PROJETO DE LEI COMPLEMENTAR Nº 125, DE 1996)}

O Congresso Nacional decreta:

Art $1^{\circ}$ - Na instituição de taxa de iluminação pública, os Municípios deverão obedecer aos seguintes critérios:

a) somente será cobrada de imóveis localizados em logradouro dotado de iluminação pública;

b) terá a testada ou a área do imóvel como base de cálculo, que não se confundirá com a base de cálculo do imposto predial e territorial urbano;

c) o seu valor não poderá ultrapassar o limite de dez por cento do imposto predial e territorial urbano.

Art. $2^{\circ}$ - Considera-se a iluminação pública em bem de uso comum um serviço público específico e divisível.

Art. $3^{\circ}$ - Esta lei complementar entra em vigor na data de sua publicação.

\section{PROJETO DE LEI COMPLEMENTAR n 125, DE 1996}

(Do Sr. Marçal Filho)

Estabelece a proibição de cobrança de taxa de iluminação pública, nas condições que especifica.

O Congresso Nacional decreta:

Art. $1^{\circ}$ - É vedada a cobrança de taxa de iluminação pública:

a) que tenha como base de cálculo ou fato gerador o consumo domiciliar de energia elétrica ou a área ou a testada do imóvel;

b) ou que se aplique por serviço de uso comum e indivisível.

Art. $2^{\circ}$ - Esta lei complementar entra em vigor na data de sua publicação. 


\section{PROJETO DE LEI COMPLEMENTAR n²26, DE 1998}

(Do Sr. Alexandre Santos)

Proíbe a cobrança de taxa de iluminação pública

O Congresso Nacional decreta:

Art. $1^{\circ}$ - É vedada a cobrança de taxa de iluminação pública de ruas, avenidas, praças e logradouros congêneres.

Parágrafo único - A iluminação pública é considerada serviço público genérico e indivisível.

Art. $2^{\circ}$ - Esta lei complementar entra em vigor na data de sua publicação. 